UNIVERSIDADE DE SÃO PAULO

FACULDADE DE ARQUITETURA E URBANISMO

PROGRAMA DE PÓS-GRADUAÇÃO EM ARQUITETURA E URBANISMO

\title{
FINANÇAS PÚBLICAS
}

\section{E O FINANCIAMENTO FISCAL DO DESENVOLVIMENTO URBANO BRASILEIRO ENTRE 2000 E 2016}

GIUSEPE FILOCOMO

SÃO PAULO, 2020 


\title{
FINANÇAS PÚBLICAS
}

\section{E O FINANCIAMENTO FISCAL DO DESENVOLVIMENTO URBANO BRASILEIRO ENTRE 2000 E 2016}

Dissertação apresentada à Faculdade de Arquitetura e Urbanismo da Universidade de São Paulo, no âmbito do Programa de Pós-graduação em Arquitetura e Urbanismo, área de concentração do Habitat.

\author{
Mestre em Ciências \\ GIUSEPE FILOCOMO
}

Orientadora

PROFa DRa LUCIANA DE OLIVEIRA ROYER

Exemplar revisado e alterado em relação à versão original, sob responsabilidade do autor e anuência da orientadora. A versão original, em formato digital, ficará arquivada na Biblioteca da Faculdade. São Paulo, 10 de julho de 2020.

SÃO PAULO, 2020 
Autorizo a reprodução e divulgação total ou parcial deste trabalho, por qualquer meio convencional ou eletrônico, para fins de estudo e pesquisa, desde que citada a fonte.

Endereço eletrônico do autor: giusepefilocomo@usp.br ; giusepefilocomo@gmail.com .

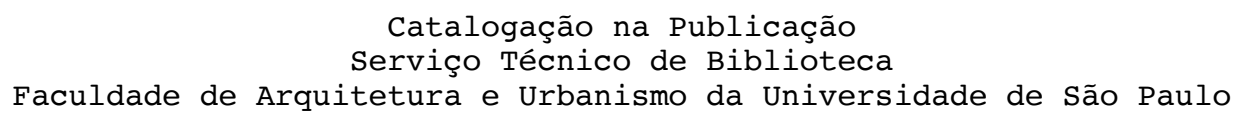

1. Desenvolvimento Urbano. 2. Finanças Públicas. 3. Orçamento Público. 4. Financiamento Infraestrutura Urbana e Habitacional. 5. Política Pública. 6. Brasil. I. Royer, Luciana de Oliveira, orient. II. Título.

Elaborada eletronicamente através do formulário disponível em: <http://www.fau.usp.br/fichacatalografica/> 
Rua do Lago, 876 (05508-080) - Caixa Postal 61523 (05424.970) - São Paulo - Brasil

Tel 1138132511 - Fax 1138132932

http://www.usp.br/fau

\section{CERTIFICADO DE DEFESA DE MESTRADO NÃO PRESENCIAL}

Certifico que em 10 de junho de 2020 realizou-se a defesa de Dissertação não presencial do(a) aluno(a) GIUSEPE FILOCOMO, de maneira remota, por meio da seguinte plataforma de conferência online:

Google Meet, no seguinte link: https://meet.google.com/ueu-dbed-hno?authuser $=0$

Participaram da banca os docentes:

Presidente Profa Dra LUCIANA DE OLIVEIRA ROYER

Profa Dra URSULA DIAS PERES

Profa Dra MARIA DO LIVRAMENTO MIRANDA CLEMENTINO

A defesa iniciou-se às $10 \mathrm{~h} 05$ e encerrou-se às $12 \mathrm{~h} 30 \mathrm{~min}$.

Comentários dos membros da banca:

O candidato foi aprovado com indicação de publicação, integralmente ou em artigos científicos. A banca destaca a qualidade acadêmica do trabalho apresentado.

Resultado final: APROVADO, conforme Ata por mim preenchida e enviada em anexo.

Solicita-se que, sempre que possível, a depender da plataforma utilizada, a parte da leitura do resultado final seja gravada para registro.

Sobre as informações acima, dou fé.

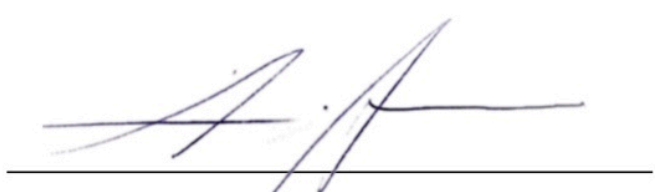

LUCIANADE OLIVEIRA ROYER 
Dedico esta dissertação à Universidade pública, gratuita e de qualidade, e à sua importância para a inclusão social, desenvolvimento e soberania nacionais. 


\section{Agradecimentos}

Agradeço à minha mentora, professora Luciana de Oliveira Royer, pelo acolhimento e imensa generosidade intelectual, reflexiva, interpessoal. As contradições no âmbito da universidade pública, ora ou outra, exigem fôlego extra, e certamente sua companhia é um lembrete sobre uma potência social, e sobre a busca por compreender as nossas cidades e país.

Agradeço ao doutor Fábio Pereira dos Santos, ao professor João Paulo Bachur, ao professor Luís Fernando Massonetto, à professora Maria do Livramento Miranda Clementino, e à professora Ursula Dias Peres pelas contribuições a esta dissertação, mas especialmente pela generosidade frente minha formação enquanto pesquisador e intelectual.

Agradeço aos meus colegas do grupo de pesquisa "Produção do espaço urbano e finanças contemporâneas: o papel do fundo público", coordenado pela professora Luciana de Oliveira Royer. Agradeço em especial a Alice dos Anjos Picariello, Ana Flávia Piacentini, Bernardo Soares dos Santos Santana, Francisco Rérisson Carvalho Correia Máximo, Lucas Piaia Petrocino, Nicholas Zbigniew Pretto Kaminski, Paulo Alas Rossi, Raphael Brito Faustino e Samuel Pedro Bícego, com quem tive o prazer de trabalhar diretamente e em conjunto. Esta dissertação beneficia-se de esforços e debates realizados no âmbito desse grupo de pesquisa.

Agradeço aos colegas de pós-graduação na Faculdade de Arquitetura e Urbanismo. Agradeço aos colegas do Laboratório de Habitação e Assentamentos Humanos, o LABHAB. Agradeço aos colegas (incluídos monitores, professores e alunos) da disciplina de Planejamento Urbano 1, ministrada em 2018. Agradeço aos colegas da Faculdade de Filosofia, Letras e Ciências Humanas e da Escola de Artes, Ciências e Humanidades pelas produtivas trocas, possíveis devido às disciplinas cursadas no Departamento de Ciência Política e programa de Gestão de Políticas Públicas. Essas disciplinas foram ministradas pela professora Marta Arretche (DCP-FFLCH-USP) e professora Ursula Dias Peres (GPP-EACH-USP), a quem também agradeço. Agradeço aos professores Beatriz Rufino, Paulo Cesar Xavier Pereira e João Sette Whitaker pelo acolhimento e reflexões em suas disciplinas, ministradas na FAU. Agradeço aos servidores e professores da Faculdade de Arquitetura e Urbanismo e da Universidade de São Paulo. 
Agradeço, em especial, à Isadora Borges e Lyzandra Machado, que me acompanham carinhosa e solidariamente desde a experiência da Residência em Arquitetura e Urbanismo da Universidade de São Paulo, e também ao Tales Fontana, nosso companheiro de morada em Natal. Agradeço à querida Isadora Marchi. Agradeço aos colegas da Residência em Arquitetura e Urbanismo da Universidade de São Paulo. Agradeço aos colegas de graduação na Universidade Estadual de Campinas.

Agradeço ao Federico pelo apoio, carinho e, sobretudo, compreensão, central durante o período de desenvolvimento desta dissertação.

Agradeço aos meus pais, Elias e Zilda, pelo amor e pelos sacrifícios, mas especialmente por sempre me apontarem a educação e os estudos enquanto condição. Agradeço aos meus irmãos, Alfredo e Guilherme, minhas referências do ontem, hoje e amanhã.

Esta dissertação beneficia-se das experiências e debates proporcionados a partir de participação em XXXVI International Congress of the Latin American Studies Association, XVIII Encontro Nacional da Associação Nacional de Pós-graduação e Pesquisa em Planejamento Urbano e Regional e II Simpósio Nacional de Gestão e Engenharia Urbana.

Agradeço à Coordenação de Aperfeiçoamento de Pessoal de Nível Superior (CAPES) pelo financiamento desta pesquisa, central a seu desenvolvimento.

Sou o único responsável pelas possíveis imprecisões apresentadas por esta dissertação. 


\section{Resumo}

A atuação estatal é engrenagem indispensável à compreensão de regime econômico contemporâneo e suas decorrências. A compreensão da atuação estatal permite articulações sociais, econômicas e também urbanas, desde que reconhecida sua estrutura enquanto expressão social, econômica e histórica. A partir do pensamento social, da história econômica e da teoria da regulação, a presente dissertação estuda a articulação entre urbano e atuação estatal a partir das finanças públicas. A investigação empírica centra-se no estudo da execução dos recursos orçamentários federais para o período de 2000 a 2016 e, em seguida, dedica atenção à receita realizada de município de São Paulo para o período de 2003 a 2016. Os dados primários orçamentários são obtidos junto ao Governo Federal e Prefeitura do Município de São Paulo, também avaliados à luz de literatura relacionada e de legislação e relatórios técnicos e orçamentários. Desse modo, e enquanto produto do campo do planejamento urbano e regional, é construída avaliação sobre o financiamento fiscal das infraestruturas urbana e habitacional durante a história recente do país, fenômeno que remonta à alocação de mais de 350 bilhões de reais e liquidação de mais de 200 bilhões de reais oriundos do Orçamento Geral da União, ano referência 2016, com implicações sobre os territórios da maior parte dos municípios brasileiros. A partir de avanços teórico-metodológicos, as relações entre urbano e atuação estatal demonstram-se enquanto potência explicativa, assim como representam possibilidade ao problema urbano brasileiro.

Palavras-chave

Brasil; Desenvolvimento urbano; Finanças públicas; Orçamento público; Financiamento; Infraestrutura urbana e habitacional; Política pública.

Como citar

FILOCOMO, Giusepe. Finanças públicas e o financiamento fiscal do desenvolvimento urbano brasileiro entre 2000 e 2016. Dissertação (Mestrado) - Programa de pós-graduação em Arquitetura e Urbanismo, Universidade de São Paulo, São Paulo, 2020. 


\begin{abstract}
Governmental activity is a fundamental mechanism to understand the contemporary economic regime and its outcomes. Governmental activity's comprehension allows for social, economic and urbanistic relations, as long as its structure is recognized as a social, economic and historical expression. This dissertation studies the liaisons between Brazilian urbanistic and governmental activity through public finances, from a social, historical-economical and regulation theory's approach. This empiric investigation focuses on the study concerning the execution of federal budgetary resources between 2000 and 2016 and, subsequently, concentrates on São Paulo municipality's revenues during the 2003-2016 period. Primary budgetary data are provided by Federal Government and São Paulo Municipality, and are also weighed through related literature, legislation and technical and budgetary reports. This way, as a product of urban and regional planning's field of study, this work suggests an evaluation on the fiscal funding of urban and habitational infrastructure during Brazil's recent history. This phenomenon counted on the allocation of more than $\mathrm{R} \$ 350$ billion and the liquidation of more than $\mathrm{R} \$ 200$ billion originating from the Federal Budget for the year 2016 and concerned most of the municipalities of the country. From a theoretic and methodologic advancement's point of view, relations between urban environment and governmental activity prove themselves as an explicatory power, also representing a possibility for the Brazilian urban problematic.
\end{abstract}

Keywords

Brazil; Urban development; Public finances; Public budget; Funding; Urban and housing infrastructure; Public policy.

How to quote

FILOCOMO, Giusepe. Finanças públicas e o financiamento fiscal do desenvolvimento urbano brasileiro entre 2000 e 2016. Dissertação (Mestrado) - Programa de pós-graduação em Arquitetura e Urbanismo, Universidade de São Paulo, São Paulo, 2020. 


\section{Lista de quadros e tabelas}

Quadro 2.1: Financiamento do desenvolvimento urbano brasileiro: recorte de pesquisa a partir de banco de dados da execução do Orçamento Geral da União (2000-2016). Ano referência valores: 2016. Elaboração nossa. 88

Quadro 3.1: Execução do Orçamento Geral da União e o financiamento do desenvolvimento urbano brasileiro: empenho e liquidação entre 2000 e 2016. Valores em milhões. Ano referência de valores: 2016. Fonte: Sistema Integrado de Planejamento e Orçamento, Ministério do Planejamento, Desenvolvimento e Gestão do Governo Federal. Elaboração nossa. 96

Quadro 3.2: Relevância fiscal do desenvolvimento urbano: relação entre financiamento desenvolvimento urbano e execução total do OGU. Fonte: Sistema Integrado de Planejamento e Orçamento, Ministério do Planejamento, Desenvolvimento e Gestão do Governo Federal. Elaboração nossa. 105

Quadro 3.3: Modalidade de aplicação recursos orçamentários destinados ao desenvolvimento urbano Empenho e Liquidação. Valores em milhões. Ano referência de valores: 2016. Fonte: Sistema Integrado de Planejamento e Orçamento, Ministério do Planejamento, Desenvolvimento e Gestão do Governo Federal. Elaboração nossa.

107

Quadro 3.4: Recursos orçamentários federais destinados ou sob supervisão do Fundo Nacional de Habitação de Interesse Social (FNHIS) entre 2006 e 2016 (Unidades orçamentárias 56902; 74911). Ano referência de valores: 2016. Fonte: Sistema Integrado de Planejamento e Orçamento, Ministério do Planejamento, Desenvolvimento e Gestão do Governo Federal. Elaboração nossa. $\quad 110$

Quadro 3.5: Recursos orçamentários federais destinados às diferentes modalidades do Programa Minha Casa, Minha Vida, inclusive a Rural (Ações orçamentárias: 00AF; 00CW; 00CX; 00CY; 0E64). Valores em milhões. Ano referência de valores: 2016. Fonte: Sistema Integrado de Planejamento e Orçamento, Ministério do Planejamento, Desenvolvimento e Gestão do Governo Federal. Elaboração nossa. 111

Quadro 3.6: Responsabilidade pelos recursos orçamentários federais destinados ao desenvolvimento urbano (Órgão orçamentário) - Empenho e Liquidação. Valores em milhões. Ano referência de valores: 2016. Fonte: Sistema Integrado de Planejamento e Orçamento, Ministério do Planejamento, Desenvolvimento e Gestão do Governo Federal. Elaboração nossa. $\quad 115$

Quadro 3.1.1: Liquidação dos recursos orçamentários federais por eixo do desenvolvimento urbano. Valores em milhões. Ano referência de valores: 2016. Fonte: Sistema Integrado de Planejamento e Orçamento, Ministério do Planejamento, Desenvolvimento e Gestão do Governo Federal. Elaboração nossa.

119

Quadro 3.1.2: Financiamento fiscal da Habitação: valores liquidados por ação orçamentária. Valores em milhões. Ano referência de valores: 2016. Fonte: Sistema Integrado de Planejamento e Orçamento, Ministério do Planejamento, Desenvolvimento e Gestão do Governo Federal. Elaboração nossa. 123

Quadro 3.1.3: Financiamento fiscal do Saneamento Básico: valores liquidados por ação orçamentária. Valores em milhões. Ano referência de valores: 2016. Fonte: Sistema Integrado de Planejamento e Orçamento, Ministério do Planejamento, Desenvolvimento e Gestão do Governo Federal. Elaboração nossa.

126 
Quadro 3.1.4: Financiamento fiscal da Mobilidade Urbana: valores liquidados por ação orçamentária. Valores em milhões. Ano referência de valores: 2016. Fonte: Sistema Integrado de Planejamento e Orçamento, Ministério do Planejamento, Desenvolvimento e Gestão do Governo Federal. Elaboração nossa.

128

Quadro 3.1.5: Financiamento fiscal da Energia elétrica: valores liquidados por ação orçamentária. Valores em milhões. Ano referência de valores: 2016. Fonte: Sistema Integrado de Planejamento e Orçamento, Ministério do Planejamento, Desenvolvimento e Gestão do Governo Federal. Elaboração nossa.

131

Quadro 3.1.6: Financiamento fiscal da Infraestrutura urbana: valores liquidados por ação orçamentária. Valores em milhões. Ano referência de valores: 2016. Fonte: Sistema Integrado de Planejamento e Orçamento, Ministério do Planejamento, Desenvolvimento e Gestão do Governo Federal. Elaboração nossa.

133

Quadro 3.1.7: Financiamento fiscal do Planejamento e Gestão Pública: valores liquidados por ação orçamentária. Valores em milhões. Ano referência de valores: 2016. Fonte: Sistema Integrado de Planejamento e Orçamento, Ministério do Planejamento, Desenvolvimento e Gestão do Governo Federal. Elaboração nossa. 136

Quadro 3.1.8: Financiamento fiscal das Operações Especiais: valores liquidados por ação orçamentária. Valores em milhões. Ano referência de valores: 2016. Fonte: Sistema Integrado de Planejamento e Orçamento, Ministério do Planejamento, Desenvolvimento e Gestão do Governo Federal. Elaboração nossa.

140

Quadro 3.2.1: Territorialização do financiamento fiscal do desenvolvimento urbano a partir da execução do Orçamento Geral da União, 2000 a 2016. Ano referência de valores: 2016. Fonte: Sistema Integrado de Planejamento e Orçamento, Ministério do Planejamento, Desenvolvimento e Gestão do Governo Federal. Elaboração nossa.

144

Quadro 3.2.2: Territorialização do financiamento fiscal do desenvolvimento urbano por região, 2000 a 2016. Valores liquidados, em milhões. Ano referência de valores: 2016. Fonte: Sistema Integrado de Planejamento e Orçamento, Ministério do Planejamento, Desenvolvimento e Gestão do Governo Federal. Elaboração nossa.

146

Quadro 3.3.1: Receita Realizada do Município de São Paulo e a participação das Transferências Intergovernamentais e de Convênios Interfederativos. Ano referência 2016. Fonte: Prefeitura do Município de São Paulo. Elaboração nossa.

163

Quadro 3.3.2: Receita realizada de Convênios e Transferências Estaduais destinadas ao financiamento do desenvolvimento urbano de município de São Paulo. Ano referência 2016. Fonte: Prefeitura do Município de São Paulo. Elaboração nossa.

165

Quadro 3.3.3: Receita realizada de Convênios e Transferências Federais destinadas ao financiamento do desenvolvimento urbano de município de São Paulo. Ano referência 2016. Fonte: Prefeitura do Município de São Paulo. Elaboração nossa. 169

Quadro 3.3.4: Receita realizada do município de São Paulo e Convênios e Transferências Interfederativas destinadas ao financiamento do desenvolvimento urbano (considerados os recursos destinados ao FMSAl como transferências do estado de São Paulo). Ano referência: 2016. Fonte: Prefeitura do Município de São Paulo. Elaboração nossa.

172 
Quadro Anexo 1: Indicadores econômicos nacionais. Ano referência de valores: 2016. Fonte: Sistema Integrado de Planejamento e Orçamento, Ministério do Planejamento, Desenvolvimento e Gestão do Governo Federal; Secretaria do Tesouro Nacional, Ministério da Fazenda do Governo Federal; Banco Central do Brasil; Instituto Brasileiro de Geografia e Estatística. Elaboração nossa 202

Quadro Anexo 2: Classificações programáticas por eixo do desenvolvimento urbano - Recursos empenhados por ano. Valores em milhões. Ano referência de valores: 2016. Fonte: Sistema Integrado de Planejamento e Orçamento, Ministério do Planejamento, Desenvolvimento e Gestão do Governo Federal. Elaboração nossa. 205

Quadro Anexo 3: Classificações programáticas por eixo do desenvolvimento urbano - Recursos liquidados por ano. Valores em milhões. Ano referência de valores: 2016. Fonte: Sistema Integrado de Planejamento e Orçamento, Ministério do Planejamento, Desenvolvimento e Gestão do Governo Federal. Elaboração nossa. 208

Quadro Anexo 4: Territorialização do financiamento fiscal do desenvolvimento urbano: Valores empenhados por Estado. Valores em milhões. Ano referência de valores: 2016. Fonte: Sistema Integrado de Planejamento e Orçamento, Ministério do Planejamento, Desenvolvimento e Gestão do Governo Federal. Elaboração nossa. 209

Quadro Anexo 5: Territorialização do financiamento fiscal do desenvolvimento urbano: Valores liquidados por Estado. Valores em milhões. Ano referência de valores: 2016. Fonte: Sistema Integrado de Planejamento e Orçamento, Ministério do Planejamento, Desenvolvimento e Gestão do Governo Federal. Elaboração nossa. 210

Quadro Anexo 6: Receita realizada de Convênios e Transferências Estaduais destinadas ao financiamento do desenvolvimento urbano de município de São Paulo. Valores em milhões. Ano referência 2016. Fonte: Prefeitura do Município de São Paulo. Elaboração nossa.

211

Quadro Anexo 7: Receita realizada de Convênios e Transferências Federais destinadas ao financiamento do desenvolvimento urbano de município de São Paulo. Valores em milhões. Ano referência 2016. Fonte: Prefeitura do Município de São Paulo. Elaboração nossa. 


\section{Lista de gráficos}

Gráfico 1.1.1: Taxa de urbanização brasileira. Fonte: Séries estatísticas IBGE.

41

Gráfico 3.1: Execução do Orçamento Geral da União e o financiamento do desenvolvimento urbano brasileiro: empenho e liquidação entre 2000 e 2016. Ano referência de valores: 2016. Fonte: Sistema Integrado de Planejamento e Orçamento, Ministério do Planejamento, Desenvolvimento e Gestão do Governo Federal. Elaboração nossa.

97

Gráfico 3.2: Relevância fiscal do desenvolvimento urbano: relação entre financiamento desenvolvimento urbano e execução total do OGU. Fonte: Sistema Integrado de Planejamento e Orçamento, Ministério do Planejamento, Desenvolvimento e Gestão do Governo Federal. Elaboração nossa. 105

Gráfico 3.3: Modalidade de aplicação recursos orçamentários destinados ao desenvolvimento urbano Empenho. Ano referência de valores: 2016. Fonte: Sistema Integrado de Planejamento e Orçamento, Ministério do Planejamento, Desenvolvimento e Gestão do Governo Federal. Elaboração nossa. 109

Gráfico 3.4: Recursos orçamentários federais destinados ou sob supervisão do Fundo Nacional de Habitação de Interesse Social (FNHIS) entre 2006 e 2016 (Unidades orçamentárias 56902; 74911). Ano referência de valores: 2016. Fonte: Sistema Integrado de Planejamento e Orçamento, Ministério do Planejamento, Desenvolvimento e Gestão do Governo Federal. Elaboração nossa. 110

Gráfico 3.5: Recursos orçamentários federais destinados às diferentes modalidades do Programa Minha Casa, Minha Vida, inclusive a Rural (Ações orçamentárias: 00AF; 00CW; 00CX; 00CY; 0E64). Ano referência de valores: 2016. Fonte: Sistema Integrado de Planejamento e Orçamento, Ministério do Planejamento, Desenvolvimento e Gestão do Governo Federal. Elaboração nossa. 112

Gráfico 3.6: Responsabilidade pelos recursos orçamentários federais destinados ao desenvolvimento urbano (Órgão orçamentário) - Empenho. Ano referência de valores: 2016. Fonte: Sistema Integrado de Planejamento e Orçamento, Ministério do Planejamento, Desenvolvimento e Gestão do Governo Federal. Elaboração nossa.

116

Gráfico 3.1.1: Liquidação dos recursos orçamentários federais por eixo do desenvolvimento urbano Valores absolutos e relativos por ano. Ano referência de valores: 2016. Fonte: Sistema Integrado de Planejamento e Orçamento, Ministério do Planejamento, Desenvolvimento e Gestão do Governo Federal. Elaboração nossa.

120

Gráfico 3.3.1: Receita Realizada do Município de São Paulo e a participação das Transferências Intergovernamentais e de Convênios Interfederativos. Ano referência 2016. Fonte: Prefeitura do Município de São Paulo. Elaboração nossa.

164

Gráfico 3.3.2: Receita realizada de Convênios e Transferências Estaduais destinadas ao financiamento do desenvolvimento urbano de município de São Paulo. Ano referência 2016. Fonte: Prefeitura do Município de São Paulo. Elaboração nossa.

165

Gráfico 3.3.2a: Receita realizada de Convênios e Transferências Estaduais destinadas ao financiamento do desenvolvimento urbano de município de São Paulo - desconsiderados os recursos destinados ao FMSAI. Ano referência 2016. Fonte: Prefeitura do Município de São Paulo. Elaboração nossa. 167

Gráfico 3.3.3: Receita realizada de Convênios e Transferências Federais destinadas ao financiamento do desenvolvimento urbano de município de São Paulo. Ano referência 2016. Fonte: Prefeitura do Município de São Paulo. Elaboração nossa.

169 
Gráfico 3.3.4: Receita realizada do município de São Paulo e Convênios e Transferências Interfederativas destinadas ao financiamento do desenvolvimento urbano (considerados os recursos destinados ao FMSAI como transferências do estado de São Paulo). Ano referência: 2016. Fonte: Prefeitura do Município de São Paulo. Elaboração nossa. 173 


\section{Lista de imagens}

Imagem 1.1.1 e 1.1.2: Thomaz Farkas retrata a construção de Brasília em 1960. Foto "Vista de Brasília". Thomaz Farkas retrata a autoconstrução do entorno de Brasília em 1959, ainda antes da inauguração da nova capital. Foto "Núcleo Bandeirante". Imagens extraídas de Sampaio (2016). 39

Imagem 1.2.1.1 e 1.2.1.2: Construção de grandes conjuntos habitacionais no extremo leste do município de São Paulo. Acervo CDTec Cohab-SP. Imagens extraídas de Souza (2014). 45

Imagem 3.2.1: Financiamento fiscal do desenvolvimento urbano entre 2000 e 2016: alocação territorial dos gastos com desenvolvimento urbano, alocação organizada por município. Elaboração nossa.145

Imagem 3.2.2: Casos de territórios dos municípios das regiões Nordeste, Sudeste, Centro-Oeste e Sul beneficiados pelo financiamento fiscal do desenvolvimento urbano. Fonte: Google Earth.

148

Imagem 3.2.3: Município de Nhamundá, Amazonas, beneficiado pelo financiamento fiscal do desenvolvimento urbano. Fonte: Google Earth. 150

Imagem 3.2.4: Financiamento fiscal do desenvolvimento urbano entre 2000 e 2016: alocação territorial dos gastos com Habitação, alocação organizada por município. Elaboração nossa. 154

Imagem 3.2.5: Financiamento fiscal do desenvolvimento urbano entre 2000 e 2016: alocação territorial dos gastos com Saneamento Básico, alocação organizada por município. Elaboração nossa. 155

Imagem 3.2.6: Financiamento fiscal do desenvolvimento urbano entre 2000 e 2016: alocação territorial dos gastos com Mobilidade Urbana, alocação organizada por município. Elaboração nossa.

156

Imagem 3.2.7: Financiamento fiscal do desenvolvimento urbano entre 2000 e 2016: alocação territorial dos gastos com Energia Elétrica, alocação organizada por município. Elaboração nossa. 157

Imagem 3.2.8: Financiamento fiscal do desenvolvimento urbano entre 2000 e 2016: alocação territorial dos gastos com Infraestrutura Urbana, alocação organizada por município. Elaboração nossa. 158

Imagem 3.2.9: Financiamento fiscal do desenvolvimento urbano entre 2000 e 2016: alocação territorial dos gastos com Planejamento e Gestão Pública, alocação organizada por município. Elaboração nossa. 


\section{Lista de siglas}

ABRAMAT-Associação Brasileira da Indústria de Materiais de Construção

ANTP-Associação Nacional de Transportes Públicos

BCB-Banco Central do Brasil

BID-Banco Interamericano de Desenvolvimento

BNB-Banco do Nordeste do Brasil

BNDE-Banco Nacional de Desenvolvimento Econômico

BNDES-Banco Nacional de Desenvolvimento Econômico e Social

BNH-Banco Nacional de Habitação

CAGED-Cadastro Geral de Empregados e Desempregados

CCFGTS-Conselho Curador do Fundo de Garantia do Tempo de Serviço

CDHU-Companhia de Desenvolvimento Habitacional e Urbano

CEBRAP-Centro Brasileiro de Análise e Planejamento

CEF-Caixa Econômica Federal

CEU-Centro Educacional Unificado - Prefeitura do Município de São Paulo

CMO-Comissão Mista de Planos, Orçamentos Públicos e Fiscalização

CNPJ - Cadastro Nacional da Pessoa Jurídica

COHAB-Companhia Metropolitana de Habitação de São Paulo

CONOF-Consultoria de Orçamento e Fiscalização Financeira

CONORF-Consultoria de Orçamentos, Fiscalização e Controle

EC-Emenda Constitucional

FAR-Fundo de Arrendamento Residencial

FAT-Fundo de Amparo ao Trabalhador

FAU-Faculdade de Arquitetura e Urbanismo da Universidade de São Paulo

FCVS-Fundo de Compensação de Variações Salariais

FDS-Fundo de Desenvolvimento Social

FGEE-Fundo de Garantia a Empreendimentos de Energia Elétrica

FGHAB-Fundo Garantidor da Habitação Popular

FGTS-Fundo de Garantia do Tempo de Serviço 
FGV-Fundação Getúlio Vargas

FHC-Fernando Henrique Cardoso

FIESP-Federação das Indústrias do Estado de São Paulo

FIRJAN-Federação das Indústrias do Estado do Rio de Janeiro

FISANE-Fundo de Financiamento para o Saneamento

FMI-Fundo Monetário Internacional

FMSAI-Fundo Municipal de Saneamento Ambiental e Infraestrutura

FNHIS-Fundo Nacional de Habitação Social

FPE-Fundo de Participação dos Estados

FPM-Fundo de Participação dos Municípios

GV-Getúlio Vargas

IBGE-Instituto Brasileiro de Geografia e Estatística

ICMS-Imposto sobre operações relativas à circulação de mercadorias e sobre prestações de serviços de transporte interestadual, intermunicipal e de comunicação

IPCA-IBGE-Índice Nacional de Preços ao Consumidor Amplo

IPEA-Instituto de Pesquisa Econômica Aplicada

JK-Juscelino Kubitschek

LABHAB-Laboratório de Habitação e Assentamentos Humanos FAU USP

LAI-Lei de Acesso à Informação

LDO-Lei de Diretrizes Orçamentárias

LOA-Lei Orçamentária Anual

LRF-Lei de Responsabilidade Fiscal

MCIDADES-Ministério das Cidades

MP-Medida Provisória

MTO-Manual técnico de orçamento

OGU-Orçamento Geral da União

PAC-Programa de Aceleração do Crescimento

PAR-Programa de Arrendamento Residencial

PASEP-Programa de Formação do Patrimônio do Servidor Público

PEC-Proposta de Emenda Constitucional

PIB-Produto Interno Bruto 
PIL-Programa de Investimento em Logística

PIS-Programa de Integração Social

PLANASA-Plano Nacional de Saneamento Básico

PLANHAB-Plano Nacional de Habitação

PMCMV-Programa Minha Casa, Minha Vida

PMSP-Prefeitura do Município de São Paulo

PNAD-Pesquisa Nacional por Amostra de Domicílio

PPI-Projeto Piloto de Investimentos

PPP-Parceria Público-Privada

PSH-Programa Subsídio à Habitação

RDC-Regime Diferenciado de Contratações Públicas

RIDE-Regiões Integradas de Desenvolvimento Econômico

RM-Regiões Metropolitanas

SABESP-Companhia de Saneamento Básico do Estado de São Paulo

SBPE-Sistema Brasileiro de Poupança e Empréstimos

SEHAB-Secretaria Municipal de Habitação - São Paulo

SERFHAU-Serviço Federal de Habitação e Urbanismo

SFH-Sistema Financeiro da Habitação

SFI-Sistema Financeiro Imobiliário

SINDUSCON-Sindicato da Indústria da Construção Civil

SIOP-Sistema Integrado de Planejamento e Orçamento

SIURB-Secretaria Municipal de Infraestrutura Urbana e Obras de São Paulo

SNHIS-Sistema Nacional de Habitação de Interesse Social

SUDAM-Superintendência do Desenvolvimento da Amazônia

SUDENE-Superintendência do Desenvolvimento do Nordeste

SUS-Sistema Único de Saúde

TCU-Tribunal de Contas da União

UH-Unidade habitacional

USP-Universidade de São Paulo 


\section{Sumário}

INTRODUÇÃO

1. DESENVOLVIMENTO URBANO BRASILEIRO

1.1 Desenvolvimento urbano enquanto produto social

1.2 Desenvolvimento urbano, a estruturação e arranjos da atuação estatal

1.2.1 Estruturação da atuação estatal

1.2.2 Rearranjo da atuação estatal

1.2.3 Resgate de mecanismos da atuação estatal

1.2.4 Políticas urbanas e habitacionais federais e o cenário de austeridade fiscal permanente

1.3 Desenvolvimento urbano enquanto fenômeno social e econômico

1.3.1 Relevância social de atuação estatal frente ao desenvolvimento urbano

1.3.2 Relevância econômica de atuação estatal frente ao desenvolvimento urbano

2. FINANÇAS PÚBLICAS A PARTIR DO DESENVOLVIMENTO URBANO

2.1 Investigação sobre as finanças públicas

2.1.1 Pergunta de pesquisa

2.1.2 Definições, premissas, ressalvas e considerações gerais sobre a pesquisa

2.2 Método de pesquisa sobre as finanças públicas

2.2.1 Estudo documental

2.2.2 Abordagem exploratória e estudo de caso

2.2.3 Apontamentos metodológicos sobre o tratamento das finanças públicas 


\section{Introdução}

Os processos e estruturas relativos ao regime de acumulação contemporâneo são expressos, assim como expressam, pela produção do urbano. Há quem discuta o caráter de mercadoria fictícia intrínseco às mercadorias casa e cidade, com implicações sobre as relações de produção e apropriação do espaço, sendo esse caráter exacerbado pela lógica e domínio das finanças no tempo atual. ${ }^{1}$ Do mesmo modo, os processos de expansão próprios do regime de acumulação associam-se às características de formações sociais específicas, padrões produtivos, e conformam-se também de acordo com a condição centro-periferia das economias nacionais. ${ }^{2}$ Esse debate ganha força com a crise global de $2008 .^{3}$ Com atenção a isso, estudos tratam de desvelar as permanências e rupturas nas estruturas de propriedade, fluxos de riqueza, técnicas construtivas e relações no mundo do trabalho, por exemplo, de modo a iluminar os processos da produção do urbano no tempo contemporâneo brasileiro, latinoamericano e mundial. $^{4}$

De modo não dissonante, o pensamento social e a história econômica brasileira demonstram a relevância de atuação estatal para a compreensão do desenvolvimento nacional historicamente, ${ }^{5}$ sendo o urbano uma condição e condicionado por fenômenos sociais, econômicos ${ }^{6}$ e também pela atuação estatal. ${ }^{7}$ É verificada a relevância das finanças públicas para o entendimento de processos produtivos no país, debate melhor situado à luz de condição periférica da economia brasileira.

Desse modo, enquanto produto do campo do planejamento urbano e regional, a presente dissertação estuda as relações entre urbano e atuação estatal a partir das finanças públicas. A complexidade de tais objetos de pesquisa justifica a confluência de diferentes literaturas e horizontes normativos, por vezes incompatíveis entre si. Por um lado, estudos

\footnotetext{
${ }^{1}$ Rufino, 2017; Klink; Souza, 2017; Lencioni, 2017.

${ }^{2}$ Oliveira, 1981 [1972]; 1990; 2018 [2006]; Paulani, 2012; De Paula et al., 2017; Prates et al., 2017.

3 Boyer, 2012; Schäfer; Wolfgang, 2013; Streeck, 2014.

${ }^{4}$ Ball, 1981; Harvey, 1982 [1976]; Carmago et al., 1975; Kowarick, 1993 [1979]; Fix; Paulani, 2019.

${ }^{5}$ Oliveira, 1988; Tavares, 1999; 2019; Fiori, 1998; 2004; Lopreato, 2013; Paulani, 2012.

${ }^{6}$ Oliveira, 1979; Maricato, 1979; Cano, 2011.

7 Bolaffi, 1975; Maricato, 2015; Royer, 2009; Maricato; Royer, 2017; Arretche, 2015; Cardoso; Aragão, 2013; Cardoso; Jaenisch; Aragão, 2017.
} 
apontam a relevância das assimetrias de informações e práticas de gestão para a compreensão ou qualificação de atuação estatal. Por outro lado, em especial frente ao resgate de alguns mecanismos de intervenção econômica pelo Estado brasileiro durante o início do século XXI, com atenção à articulação de projetos e financiamento de infraestruturas urbana e habitacional, estudos sobre a produção social do espaço retomam suas inquietações sobre a atuação estatal. A primeira perspectiva, ao passo que avança sobre a compreensão da agência, parece conferir menor visibilidade às estruturas pertinentes à atuação estatal. A segunda perspectiva, centrada nos processos sociais e ambiente construído, tende a obscurecer a sofisticação e certa autonomia estatal e sua relevância para a determinação do produto urbano. Ambas abordagens são pertinentes frente a complexidade de mundo social.

A pesquisa sobre a atuação estatal pode permitir articulações econômicas, sociais e também urbanas. Neste sentido, a presente dissertação reconhece a importância das estruturas sociais brasileiras para a compreensão do problema urbano no país, do mesmo modo como reconhece a complexidade do Estado, enquanto instituição detentora de identidade e interesse próprio, enquanto expressão econômica, social e histórica brasileira. Tal acepção implica dedicar atenção à estrutura estatal, dado que a precisão analítica também contribui para a precisão de avaliações. A intersecção entre urbano e atuação estatal não é trivial, e implica desafios teóricos, a exemplo do não-diálogo entre individualismo metodológico e holismo radical, e também em termos de métodos e categorias analíticas. Com atenção a esse debate, a presente dissertação viabiliza-se teoricamente pela articulação entre pensamento social, história econômica e teoria da regulação, esta orientada pela articulação do par conceitual modo de regulação e regime de acumulação, consentâneo ao estudo das relações entre urbano e atuação estatal a partir das finanças públicas.

O urbano, ou o fato urbano, é evidência material de um processo, a urbanização. ${ }^{8}$ Avanços interpretativos sobre a urbanização distanciam-se da ideia da atração populacional em

\footnotetext{
${ }^{8}$ Poderíamos avançar sobre a categoria espaço. Em palestra intitulada "Da Paisagem ao Espaço", o professor Milton Santos apresenta uma definição a essa categoria. O espaço seria um conjunto indissolúvel entre sistema de objetos e sistema de ações. A palestra foi ministrada na FAU USP no ano de 1995, e encontra-se disponível em <https://www.youtube.com/watch?v=juUkCzFTO5U>, consultado em fevereiro de 2020, conteúdo apresentado por volta do minuto 18 e 19 de vídeo. Outra categoria a ser explorada seria espaço urbano.
} 
relação à concentração de oportunidades, uma vez que a pobreza urbana dissolve essa proposição, de modo que compreender o processo de urbanização demanda o estudo social. ${ }^{9}$ O processo de urbanização é condição, meio e produto de uma reprodução social, o que se relaciona com a ideia de um espaço socialmente produzido (produto), ou produção social do espaço (processo). ${ }^{10}$ Neste sentido, relação social e processo social demonstram-se categorias relevantes aos estudos sobre o urbano, ${ }^{11}$ sendo as relações sociais também objetos de compreensão científica. ${ }^{12}$ Ainda, em especial a partir do Estado Novo, em associação a uma atuação estatal sobre os campos político e econômico, frente a uma aposta na possibilidade de desenvolvimento capitalista baseado na industrialização, o urbano é mobilizado enquanto objeto de planejamento, também com vistas ao enfrentamento do problema urbano. ${ }^{13} \mathrm{~A}$

${ }^{9}$ Déak (2016; p.166-8) defende relação histórica entre industrialização e a urbanização brasileira, faces do processo de desenvolvimento capitalista (Deák, 2016; p.167). A industrialização não possui nexos claros com a urbanização de todas as regiões do Brasil. Agradecemos aos comentários da professora doutora Karina de Oliveira Leitão. Esse debate será tratado adiante pelo presente trabalho. Singer (1968) e Oliveira (1982) tratam de faces da urbanização sem industrialização, por exemplo.

${ }^{10}$ Lencioni (2017) trata da relação entre urbanização e metropolização. A metrópole paulistana seria um produto socialmente produzido pelo processo de metropolização do espaço, este relacionado a uma reestruturação produtiva, para citar exemplo de referência sobre articulação dos termos espaço socialmente produzido (produto) e produção social do espaço (processo).

11 "Mas a cidade é também, e sobretudo, a morfologia petrificada de uma forma de divisão social do trabalho que separa o campo da cidade e que joga quem foi expropriado de seus meios de vida na convivência com os expropriadores. É, portanto, teia viva de relações sociais e, no caso da cidade orgulhosamente capitalista, é também expressão imediata de uma forma de exploração social e econômica. [...] Não é de agora que o autor (Kowarick) se debruça sobre o fenômeno urbano para entendê-lo no contexto de um sistema produtivo mais amplo e para especificá-lo como processo social" (Cardoso in Kowarick, 1993 [1979]; pp.13-4; grifo nosso). Kowarick cunha o termo espoliação urbana.

12 Harvey (1982 [1976]) propõe quadro teórico à compreensão de conflitos relacionados à produção e uso do ambiente construído (nos termos do autor). De orientação marxista, o autor trata da relação Trabalho e Capital no ambiente construído. Verifica-se a importância do espaço no mundo social, não se trata apenas de um cenário à vida, não se trata de entender o urbano unicamente pela distribuição da riqueza socialmente produzida, mas também as próprias relações e conflitos em torno da sua produção e uso.

Ball (1981) debate a produção do urbano. Segundo o autor, o sistema capitalista domina o modo de produção das cidades na primeira metade do século XIX. Por meio de estudo sobre o contexto britânico - capitalismo central desse período, Ball demonstra como a substituição de métodos artesanais, a dominação dos meios de produção e a exploração de força de trabalho em cenário de rápida industrialização, concentração populacional e guerras napoleônicas determinam o fim das relações mercantis (sistema de ofícios) e viabilizam a apropriação da maisvalia pelos capitalistas também por meio da provisão habitacional e da infraestrutura urbana.

Jaramillo (1982) conceitua as formas de produção e modos de produção, categorias que devem ser compreendidas à luz das diferentes formações sociais. Seriam as formas de produção: encomenda, promoção privada, autoconstrução e produção estatal capitalista desvalorizada.

13 Leme, 2019. Ver também Cano (2011), o autor trata sobre a crise urbana. A presente dissertação desenvolve a ideia de problema urbano, especificada mais adiante. 
profissão planejamento urbano e a disciplina urbanismo se consolidam enquanto campos de atuação, ${ }^{14}$ fortemente relacionados à atuação estatal. ${ }^{15}$

O campo do planejamento urbano e regional apresenta categorias teóricas à compreensão do urbano brasileiro. A urbanização e a produção social do espaço são nucleares à compreensão e construção do conhecimento sobre o urbano. Esses termos são acionados pela presente dissertação nos devidos momentos, com atenção aos fenômenos por eles debatidos. Contudo, entender e precisar a relação entre o urbano e a atuação estatal demanda ainda a construção de uma categoria analítica, desenvolvimento urbano. Essa categoria analítica contribui à articulação dos eixos habitação, saneamento básico, mobilidade urbana, energia elétrica, infraestrutura urbana, planejamento e gestão pública, elementos de uma materialidade própria do urbano, assim como de uma organização da atuação estatal sobre o urbano. $^{16}$

As finanças públicas não são condição única e suficiente à compreensão do urbano, contudo, as finanças públicas são condição à atuação estatal, e esta pertinente à compreensão sobre o urbano. Neste sentido, o estudo das finanças públicas demonstra-se pertinente ao campo do planejamento urbano e regional. A articulação entre urbano, atuação estatal e finanças públicas será, assim, entendida a partir do financiamento fiscal do desenvolvimento urbano, ou seja, a partir do gasto público no Brasil. ${ }^{17}$ A presente dissertação indaga: Qual financiamento fiscal do desenvolvimento urbano é possível no Brasil? O presente estudo está inserido na articulação atuação estatal, finanças públicas e urbano. Contudo, o centro argumentativo é o urbano, e por isso a pergunta de pesquisa refere-se a seu financiamento. ${ }^{18}$

\footnotetext{
${ }^{14}$ Leme (1999) desenvolve periodização e trata sobre a evolução histórica da disciplina urbanismo e profissão planejamento urbano no Brasil.

15 Leme, 2019.

${ }^{16}$ Não há definição única ou consensual sobre os elementos que compõe o urbano. Harvey (1982 [1976]; p.6) trata o ambiente construído enquanto a totalidade das estruturas físicas "casas, ruas, fábricas, escritórios, sistemas de esgotos, parques, equipamentos culturais e educacionais etc". Nos orientamos por essa ideia. Ainda, tratamos de conciliar essa perspectiva ao entendimento de serviços urbanos básicos, tal como apresentado por Arretche (2015), por exemplo. Os eixos do desenvolvimento urbano propostos também tratam de reconhecer a estruturação da atuação estatal sobre o urbano, inclusive com atenção à empiria tratada este estudo. Uma definição para cada eixo é apresentada mais adiante por este estudo.

${ }^{17}$ A presente dissertação entende o gasto público como a execução de recursos orçamentários, principalmente. Essa relação é evidenciada pelo método de pesquisa, debatido adiante.

${ }^{18}$ Se o centro argumentativo fosse o Estado, a pergunta poderia referir-se ao gasto público.
} 
Por financiamento nos referimos ao ato de prover recursos financeiros necessários à atuação estatal, à alocação e execução de recursos orçamentários. Responder a essa pergunta demanda compreender como e qual financiamento fiscal do desenvolvimento urbano ocorre no Brasil. Para tal, é necessário estabelecer definições, reconhecer premissas e apresentar as ressalvas de pesquisa. É central ao debate uma avaliação quali-quantitativa precisa sobre a alocação das finanças públicas a partir da perspectiva do urbano.

A presente dissertação visa ser uma contribuição teórico-metodológica. Uma contribuição teórica, em termos de definições, categorias e articulações teóricas; e metodológica, em termos de avaliação, processos e tratamento de dados primários. Essa contribuição se faz necessária devido à complexidade de universo empírico e fenômeno tratados pela pesquisa. A respeito das finanças públicas, são 5.570 municípios, 26 estados, 1 Distrito Federal e a União, entes com orçamentos fiscais próprios e competentes de atuação sobre o urbano. Apenas no que se refere ao Orçamento Geral da União, o estudo das relações entre urbano, atuação estatal e finanças públicas demanda a avaliação de banco de dados primários composto por 535.081 rubricas orçamentárias, a partir do qual elabora-se recorte de pesquisa, sendo o recorte composto por 50.710 rubricas orçamentárias.

A investigação empírica centra-se no estudo da execução dos recursos orçamentários federais para o período de 2000 a 2016 e, em seguida, dedica atenção à receita realizada do município de São Paulo para o período de 2003 a 2016. Com isso a pesquisa abarca universo representativo do financiamento fiscal com vistas ao desenvolvimento urbano na história recente do país. Os dados primários orçamentários são obtidos junto ao Governo Federal e Prefeitura do Município de São Paulo, também avaliados à luz da literatura relacionada e da legislação e relatórios técnicos e orçamentários. Enquanto produto do campo do planejamento urbano e regional, é construída avaliação sobre o financiamento fiscal das infraestruturas urbana e habitacional durante a história recente do país, fenômeno que remonta à alocação de mais de 350 bilhões de reais e liquidação de mais de 200 bilhões de reais oriundos do Orçamento Geral da União, ano referência 2016, com implicações sobre os territórios da maior parte dos municípios brasileiros. 
Dito isso, a presente dissertação está organizada em quatro capítulos, para além deste. Como um todo, o primeiro capítulo (1) situa a presente dissertação no campo do conhecimento, tratando da literatura sobre o urbano, sobre a atuação estatal e sobre finanças públicas. São mobilizados estudos do planejamento urbano e regional, sociologia, ciências econômicas, ciência política e administração pública. A primeira seção deste capítulo (1.1) resgata e articula leituras sobre o urbano no Brasil, de modo a apresentar as bases teóricas e empíricas para uma compreensão das cidades brasileiras. A segunda seção (1.2) trata, especialmente, da estruturação estatal frente ao urbano no país. A primeira e segunda seção estão articuladas, também tratando de dados históricos sobre as finanças públicas. A terceira seção (1.3) está organizada em duas subseções (1.3.1 e 1.3.2). Como um todo, a terceira seção argumenta a relevância da atuação estatal frente ao urbano, com atenção especial ao problema urbano brasileiro. Essa relevância assume feições econômicas e sociais. Com atenção à literatura, o segundo capítulo (2) estrutura a investigação empírica, apresentando pergunta de pesquisa, definições, premissas, ressalvas e os métodos de pesquisa, abordagem exploratória e estudo de caso. O terceiro capítulo (3) avalia o financiamento fiscal do desenvolvimento urbano brasileiro, com foco sobre a execução dos recursos orçamentários federais para o período de 2000 a 2016. O terceiro capítulo está organizado em seções. Logo ao início, o terceiro capítulo (3) apresenta, detalha e compreende a execução do Orçamento Geral da União para o período de 2000 a 2016. A primeira seção (3.1) avalia a execução do Orçamento Geral da União à luz dos eixos do desenvolvimento urbano. A segunda seção (3.2) compreende as relações entre financiamento fiscal, eixos do desenvolvimento urbano e expressão territorial desse gasto público, ou seja, a alocação territorial dos recursos oriundos do Orçamento Geral da União. Por fim, a terceira seção (3.3) dedica atenção a estudo de caso único, aos recursos orçamentários de município de São Paulo para o período de 2003 a 2016, especificamente trata da receita realizada por este município. Ainda na última seção do terceiro capítulo (3.3), é avaliada a execução descentralizada do financiamento fiscal do desenvolvimento urbano no Brasil. O capítulo Conclusão apresenta nossas considerações sobre a articulação entre urbano, atuação estatal e finanças públicas. 
A compreensão do mundo social é central ao debate sobre o urbano, e a atenção à empiria desfaz estímulos a simplificações. O trabalho se desenvolve, portanto, na perspectiva de avanço empírico-teórico sobre as relações entre urbano e atuação estatal, demonstradas enquanto potência explicativa, assim como possibilidade frente ao problema urbano. Enfatizamos a atuação estatal, ou o Estado, enquanto engrenagem indispensável à compreensão de regime econômico contemporâneo e suas decorrências. O Estado é uma estrutura complexa, que merece atenção por parte dos estudos sobre o urbano no Brasil, com atenção às estruturas econômicas e sociais de nosso país, sendo essa a orientação adotada por este trabalho. 


\section{Desenvolvimento urbano brasileiro}

Na década de 1970 o pensamento social brasileiro apresentou o urbano enquanto produtor e produto social. ${ }^{19}$ Estudos seminais foram capazes de avançar teórica e criticamente sobre o dual crescimento e pobreza, por exemplo. ${ }^{20} \mathrm{O}$ urbano tanto é consequência das relações sociais de produção e distribuição de riqueza, quanto determinam o acesso à riqueza socialmente produzida. À maioria dos trabalhadores, a solução à mercadoria moradia não coube no salário direto ou indireto, Ihes restando a solução da autoconstrução, precária, desassociada espacialmente das infraestruturas de saneamento básico, energia elétrica, coleta de lixo, para citar exemplos caros aos urbanistas. ${ }^{21} \mathrm{O}$ urbano deu-se a partir e às margens da atuação estatal, por vezes desassociado da regulação, controle, investimentos e serviços públicos. $^{22}$ A compreensão desse fenômeno deveria, assim, também estar associada ao entendimento de estruturas sociais brasileiras. Como explicar o histórico de que a maioria das moradias nas cidades brasileiras são favelas, loteamentos ilegais, ou cortiços ${ }^{23}$ Não se trata de um fenômeno pontual, ou expressão qualitativa da técnica do planejamento urbano. ${ }^{24}$

Dada sua força explicativa, a luz dos pensadores de 1970 ainda é relevante à reflexão de importante parcela de urbanistas. ${ }^{25}$ Apesar de recorrermos à tradição da sociologia urbana

19 Oliveira, 1979; Maricato, 1979; Kowarick, 1993 [1979].

${ }^{20}$ Oliveira, 1981 [1972]; Camargo et al., 1975; Souza et al., 1980.

${ }^{21}$ Oliveira, 1979; Maricato, 1979; Kowarick, 1993 [1979]; Camargo et al., 1975.

22 Mesmo que o território autoconstruído possa vir a ser incorporado ao mercado formal.

${ }^{23}$ Maricato (2009) argumenta a relevância intelectual e quantitativa dos estudos sobre as políticas urbanas e habitacionais, mas aponta suas limitações para "[...] uma leitura mais ampla sobre a produção da habitação ou mais propriamente da estrutura de provisão de habitação [...]" (p.34). Nascimento (2011) associa-se ao debate de Maricato (2009), e debate o papel da autoconstrução nas estruturas de provisão de habitação. As autoras desenvolvem e referenciam estudos sobre as categorias autoconstrução e provisão (produção e distribuição) de habitação.

${ }^{24}$ A década de 1970 produziu a tese de que a urbanização significou o rebaixamento do custo de reprodução da força de trabalho, sendo ela mesma não a decorrência da industrialização brasileira, mas sim parte do processo. Francisco de Oliveira apresenta a tese no prefácio de Maricato (1979), e reforça: "A imbricação entre formas 'velhas' e 'novas' ajuda a compreender o processo de formação da cidade, concretamente [...]' (Oliveira, 1979; p.15 in Maricato, 1979).

${ }^{25}$ Francisco de Oliveira, Paul Singer, Lúcio Kowarick e o grupo do Centro Brasileiro de Análise e Planejamento, centro fundado em 1969. Gabriel Bolaffi, Ermínia Maricato e o grupo da Faculdade de Arquitetura e Urbanismo da Universidade de São Paulo. Exemplos para citar referências centrais ao campo do planejamento urbano e regional. Arantes (2009) desenvolve articulações sobre a efervescência intelectual na década de 1970 e nos estudos urbanos. 
brasileira inaugurada nessa década, a filiação teórica deste trabalho não significará a identificação de categorias heurísticas, e a categorização de fenômenos sociais atuais a partir destas, já que a filiação teórica, ao contrário, exige a renovação e precisão de interpretações. Sendo o urbano produtor e produto social, sua compreensão é possível a partir do melhor entendimento de nossas transformações e processos sociais, políticos e econômicos. Para complicar, o urbano não somente é uma expressão social, mas também um produto material. Dotado de materialidade, o urbano vincula-se ao espaço, e o espaço impõe a constante associação entre o produto e a produção, entre resultado e processos, passado e presente. Para exemplificar, a rede metroviária de superfície é um produto (no caso do município de São Paulo podendo remontar à década de 1970), e relaciona-se diretamente com a produção do urbano atual, ou seja, com a produção de infraestruturas urbanas e habitacionais na cidade. Este trabalho, assim, não busca comparar-se a ou reproduzir estudos urbanos, mas principalmente busca ser conduzido por seus ensinamentos. Com isso, a presente dissertação dedicará importância às evidências empíricas enquanto norte ao entendimento aqui produzido. Deste modo, a contribuição de trabalho, espera-se, concentrar-se-á sobre a identificação, avaliação, interpretação e, na medida do possível, a explicação de fenômenos sociais, políticos, e econômicos, e sua relação com o urbano brasileiro.

O urbano não pode ser explicado apenas a partir do estudo da atuação estatal, mas esta dissertação direciona-se ao estudo sobre o Estado. ${ }^{26} \mathrm{E}$ o desafio não estaria na dedução social a partir da atuação estatal, mas no entendimento do Estado a partir do social. ${ }^{27}$ Historicamente, o urbano moveu a organização e luta sociais por melhores condições de vida nas cidades brasileiras. ${ }^{28}$ Este processo conflituoso representou a disputa por e a legitimação social da atuação estatal. O Estado passa a ser cobrado pela resolução dos problemas em torno da moradia e da cidade.

\footnotetext{
${ }^{26}$ Os termos atuação estatal e Estado são acionados por presente dissertação, assumem valor semelhante em debate por nós construído.

27 Tal como argumenta Oliveira, 1979.

${ }^{28}$ Maricato, 1988.
} 
A atuação estatal é estruturada com vistas ao desenvolvimento urbano, ${ }^{29}$ e sua relevância efetiva à compreensão sobre a produção do urbano é ampliada. A presente dissertação avança sobre a atuação estatal com atenção ao urbano, e com atenção a possibilidades ao problema urbano, tal como tratado mais adiante.

O primeiro capítulo busca sustentar as afirmações já expressas, e também fundamentar as articulações e considerações apresentadas por dissertação. Para tal, retomamos brevemente o debate teórico sobre o urbano brasileiro. Apresenta-se a associação entre estudos passados e recentes sobre o urbano e as condições de vida nas cidades. Além disso, o primeiro capítulo apresentará elementos sociais e econômicos necessários à compreensão sobre a produção de infraestruturas urbanas e habitacionais. ${ }^{30}$ Por fim, argumentaremos a estruturação e relevância de atuação estatal frente ao desenvolvimento urbano e às condições de vida nas cidades brasileiras.

\subsection{Desenvolvimento urbano enquanto produto social}

O século XIX é a transição nacional entre Colônia e Primeira República. A grosso modo, o Brasil Império (1822-1889) parece ser um período de reorganização social, política e econômica nacional. O período é marcado pela reorganização da terra e trabalho no país. ${ }^{31} \mathrm{~A}$ terra, anteriormente de propriedade da Coroa, passa a ser entendida a partir da constituição de sua propriedade privada e o escravo deixa de ser entendido enquanto patrimônio. A Lei de Terras de 1850 e a Lei Áurea de 1888 são os grandes marcos deste processo. O período é especialmente conflituoso, ${ }^{32}$ inclusive conferindo espaço ao primeiro movimento social de escala nacional de nossa história, o movimento abolicionista. A partir do dissenso organizado pelo movimento abolicionista, o consenso significa uma solução de compromisso na

\footnotetext{
${ }^{29}$ Os termos urbano e desenvolvimento urbano são acionados por presente dissertação em acordo com o debate apresentado por Introdução. O termo desenvolvimento urbano comumente estará relacionado à atuação estatal, mas não apenas, também com vistas à estrutura e articulação argumentativa intra e entre capítulos da dissertação. ${ }^{30}$ Quando associadas, as infraestruturas urbana e habitacional assumem valor semelhante ao apresentado pela categoria desenvolvimento urbano.

${ }^{31}$ Deák, 2016; p.166-8.

32 Oliveira (2018 [2006]; p.32).
} 
sociedade. ${ }^{33}$ Do programa abolicionista, efetiva-se a abolição, mas não se efetiva direitos e terra aos libertos. Também não se efetiva a indenização financeira aos proprietários de escravos, defendida então pelos indenizistas. Não avançaremos sobre o entendimento deste processo. ${ }^{34}$ No que diz respeito ao urbano, e a partir da associação entre conflitos nacionais e internacionais, cabe essencialmente destacar o não-acesso à terra enquanto produto dos períodos colonial e imperial brasileiros. ${ }^{35} \mathrm{O}$ não-acesso à terra permanece e permeia os processos do século XX. ${ }^{36}$

Durante o início do século XX, a mudança da estrutura da propriedade e do estatuto do trabalho é acompanhada pelo enfraquecimento do norte e nordeste agrário, e pela diversificação das atividades econômicas ao sul e sudeste do país. A virada do século é marcada pelo surto da borracha na Amazônia (1870-1920). Ao sul e sudeste desponta a economia do café, organizada entre Minas Gerais, Rio de Janeiro, e posteriormente São Paulo e o norte do Paraná. A expansão das fronteiras econômicas por processos de exploração, produção, exportação de recursos naturais é mantida ao longo da história econômica brasileira, seja a expansão compreendida a partir dos processos e demandas internacionais, ou a partir da acomodação de heterogeneidade de sociedade nacional. ${ }^{37}$

33 Nos termos de Angela Maria Alonso. Verificar entrevista disponível em <https://www.youtube.com/watch?v=d5fJRzT3dY>, link consultado em julho de 2019.

34 Para maiores informações, verificar Smith (1990; s.i.); Secreto (2007); Alonso (2015), por exemplo. Tavares (1999) apresenta debate sobre os conflitos internacionais, apresentados pela autora a partir do estudo da geoeconomia e geopolítica. Para Oliveira (2018 [2006]; p.32): "desenvolvimento conservador a partir de rupturas históricas libertadoras".

35 Durante o período final do XIX os combatentes de Canudos ocupam o Morro da Previdência, o Morro da Favella, retratado por Tarsila do Amaral em 1924. A categoria Favela, "como problema social e como problema sociológico", deve ter seus significados e apreensões complexificados, também de acordo com o contexto histórico. "[...] as categorias de análise modificam-se ou sofrem deslocamentos conforme se alteram as estruturas da cidade, as políticas urbanas, o problema social e suas expressões políticas", de acordo com Telles (2006; p.141). ${ }^{36}$ Conforme Tavares (1999), a terra é historicamente reserva de valor da elite nacional. Tavares (1999; p.455) ainda reforça: "Os fatos relevantes para a história social e política do país parecem ter sido sempre, desde o séc. XIX, a apropriação privada do território, as migrações rurais e rural-urbanas compulsórias da população, em busca de terra e trabalho, além da centralização e descentralização do próprio domínio do Estado nacional [...]".

Segundo Ney et al. (2009; p.179), a concentração fundiária está relacionada de modo determinante aos rendimentos no meio rural brasileiro. E as famílias mais pobres e com escassez de terra no meio rural desenvolvem atividades de baixa qualificação e investimento.

${ }^{37}$ Sobre o debate deste parágrafo, ver Oliveira (2018 [2006]; p.31); Paulani (2012; p.90); Tavares (1999; p.456). 
O desenvolvimento da agroexportação, e a própria inserção nacional na economia internacional, se expressa nas cidades, no urbano brasileiro. Manaus e Belém do Pará são produto material do ciclo da borracha. ${ }^{38} \mathrm{~A}$ expansão da monocultura ajuda a compreender o papel das cidades enquanto conectores entre produção e circulação internacional de mercadorias. ${ }^{39}$ Parcela das capitais nordestinas são em grande medida produto da monocultura canavieira, assim como deve ser reconhecido o nordeste agrário algodoeiro-pecuário, este combinado à cultura de subsistência e à estrutura latifúndio-minifúndio. ${ }^{40}{ }^{41}$ Sobre a "[...] estrutura fundiária típica do latifúndio: o fundo de acumulação é dado pelas 'culturas de subsistência' do morador, do meeiro, do posseiro, que viabilizam, por esse mecanismo, um baixo custo de reprodução da força-de-trabalho e, portanto, um baixo valor que é apropriado à escala de circulação internacional de mercadorias [...]", (Oliveira, 1981; p.47). A depressão entre ciclos econômicos e históricos ajuda a compreender o urbano.

A partir da associação entre expansão interna-territorial e expansão no mercado internacional, o café configura-se enquanto mercadoria de valor. A economia brasileira assume feições determinantes para sua própria expansão econômica. Não é um processo linear, inclusive com espaço para crises do café no quartil final do XIX, mas a economia brasileira havia "[...] transbordado os limites de crescimento guiados meramente pela demanda internacional e pelo financiamento externo", ${ }^{42}$ permitindo certa consolidação de uma infraestrutura de

\footnotetext{
38 Sathler et al. (2009; p.18) apontam a relevância da inserção econômica internacional brasileira para a compreensão do desenvolvimento urbano da Amazônia Legal. Segundo os autores, identificam-se categorias: cidades da borracha, cidades da grande empresa mineradora, as cidades do garimpo, as cidades industriais, as cidades agroindustriais, por exemplo. Manaus e Belém foram impulsionadas pelo ciclo da borracha, e após o seu fim, buscam novos de sobrevivência. Esforços são a Zona Franca de Manaus (20\% PIB da Amazônia Legal); e a indústria tradicional, extrativismo, turismo, comércio e serviços sustentam as atividades de Belém.

${ }^{39}$ Oliveira, 1982; pp.37-8.

40 Oliveira, 1981; p.48.

${ }^{41} \mathrm{O}$ caso da cidade de Natal, Rio Grande do Norte, aponta ainda particularidades internas à região nordestina do país. Seu desenvolvimento aponta a particularidade da ocupação norte-americana do território no século XX, por exemplo. Tal aspecto do desenvolvimento de Natal relaciona-se com os esforços de Vargas na conciliação de divergências no âmbito do poder militar brasileiro, em prol da neutralidade frente à $2 \underline{a}$ Guerra Mundial mantida até o ano de 1942 (Tavares, 1999; p.460).

${ }^{42}$ A expressão "transbordar os limites", quando analisada fora do contexto apresentado por Tavares (1999), pode conduzir a uma interpretação errônea. A autora não apresenta uma concepção etapista em torno do desenvolvimento econômico, mas trata de elucidar as tensões intrínsecas à economia e decorrentes da associação entre processos interno e externo à nação. Oliveira (1972) desenvolve a crítica à razão dualista. Inclusive, os primórdios da acumulação industrial brasileira apontam para diferenciação da tese básica da dependência,
} 
transportes, a formação de um "embrião" de sistema bancário nacional e a diversificação da produção para o mercado interno. ${ }^{43}$ Inicia-se a construção de uma indústria brasileira antes mesmo da Primeira Guerra Mundial, ${ }^{44}$ construção esta acentuada durante essa guerra.

Com a aceleração da diversificação produtiva e agrícola nacional, o auge do café nos anos de 1920 já não é hegemônico na economia nacional. Apesar da crise internacional da década de 1930, é no entre guerras que a economia nacional se desassocia da Inglaterra e associa-se aos Estados Unidos da América, e a expansão da rede de crédito nacional do Banco do Brasil, por exemplo, sustenta a expansão das atividades agrícolas e industriais no país. ${ }^{45}$

A expansão da indústria nacional a partir da década de 1930 tanto é produto de processos em andamento, como aponta para uma transformação social. Oliveira (1972; pp.3742) chega a enunciar uma crise do modo de regulação-regime de acumulação ${ }^{46}$ agrárioexportador, inclusive significando o aumento do custo do dinheiro emprestado à agricultura. $\mathrm{O}$ período dá espaço à construção política de um modo de regulação próprio à economia urbanoindustrial, materializada pela regulamentação de leis de trabalho a partir de uma estrutura corporativista; da possível tutela dos trabalhadores pelo Estado; inclusive com a fixação de salário mínimo de "subsistência", por exemplo. ${ }^{47}$ Na esfera da produção, destacam-se fixação de preço; gasto fiscal com fins direto ou indiretamente reprodutivos; subsídios a atividades produtivas, por exemplo. Cabe mencionar os investimentos em infraestrutura, confisco cambial ao café, expansão do crédito a taxas de juros reais negativas. A partir de um Estado autoritário, começa-se a desenhar um projeto nacional de desenvolvimento e a recomposição do pacto oligárquico com a participação dos setores médios da população. ${ }^{48}$ As variáveis da economia

supostamente possível apenas em situação de sincronia entre os movimentos internos e externos à nação (Oliveira, 1972; p.38).

43 Tavares, 1999; p.458.

${ }^{44}$ Cano (1981) apud Tavares (1999; p.459).

45 Tavares, 1999; p.459.

${ }^{46}$ Verificar teoria da regulação, Boyer (2009).

${ }^{47}$ Ainda seria necessária a compreensão sobre o trabalho informal na sociedade.

48 Tavares, 1999; p.460. Para Oliveira (2018 [2006]; p.43-4): “Getúlio Vargas reformou o Estado brasileiro, imprimindo-lhe outra vez uma forte centralização (...). A era Vargas foi um período de intervenção nos estados, derrubada de velhas oligarquias e promoção de novas lideranças. (...) federalizou e estatizou o comércio exterior, criou no Banco do Brasil a Carteira de Comércio Exterior e a Carteira de Crédito Comercial, desfez as fronteiras econômicas entre os Estados, anulando os impostos interestaduais sobre exportação e importação, instituiu o imposto de consumo e unificou o sistema fiscal; ao fazê-lo, criou o mercado em escala nacional”. 
doméstica ganham relevância para a dinâmica econômica nacional. ${ }^{49} \mathrm{~A}$ população urbana amplia-se, passa de 31\% a 36\% da população brasileira entre 1940 e $1950 .^{50}$

O projeto nacional desenvolvimentista foi iniciado verdadeiramente, contudo, durante o segundo governo Vargas (1950-1954), continuando até o governo de Juscelino Kubitschek (1956-1961), constituído desde o início por um forte núcleo industrial estatal. A esta altura, Vargas empreende a "segunda Revolução Industrial" no país. ${ }^{51}$ Nesta década é gerada a primeira possibilidade efetiva de a economia nacional conquistar sua autonomia. ${ }^{52}$ Vargas funda a Eletrobrás, que empreenderia um programa de eletrificação massivo durante a ditadura militar; funda também o Banco Nacional de Desenvolvimento Econômico (BNDE), e os bancos regionais Banco do Nordeste do Brasil e Banco da Amazônia; e inclusive promove a nacionalização da pesquisa científica, com a criação do Conselho Nacional de Pesquisa. Vargas pratica franco subsídio às importações de máquinas e equipamentos. ${ }^{53} \mathrm{~A}$ industrialização pesada concentra-se no espaço paulista, significando conflitos entre grupos industrial e cafeeiro. ${ }^{54}$ Mesmo com a concentração territorial da estrutura produtiva urbano-industrial, em 1956 a renda da indústria supera pela primeira vez a renda da agricultura. ${ }^{55}$

O Plano de Metas nacionaliza programas setoriais de infraestrutura com financiamento fiscal. ${ }^{56}$ A construção de Brasília e ocupação de centro-oeste permitiu a interiorização do desenvolvimento em associação à valorização de consideráveis extensões de terras e avanço da fronteira agrícola. ${ }^{57}$ Destaca-se a construção da rodovia Belém-Brasília. O cenário favorece as construtoras e bancos brasileiros, "[...] pilares clássicos da verdadeira burguesia nacional" (Tavares, 1999; pp.462-4). A industrialização nacional materializa-se diante da reemergência do Mercado Comum Europeu e do Japão, e no momento a política norte-americana não prioriza a

\footnotetext{
49 Paulani, 2012; p.90.

50 Taxa de urbanização brasileira segundo o Instituto Brasileiro de Geografia e Estatística (IBGE). Fonte: <https://seriesestatisticas.ibge.gov.br/>, consultado em julho de 2019.

51 Oliveira, 2018 [2006]; p.44.

52 Paulani, 2012; p.90.

53 Oliveira, 2018 [2006]; p.45.

54 Tavares, 1999; pp.462-3.

55 Oliveira, 1972; p.14.

56 Tavares, 1999; p.463. Segundo Oliveira (2018 [2006]; p.49), "Os institutos de previdência, invenção varguista, foram utilizados até o osso para construir Brasília e as novas estradas federais de abertura para o interior".

57 Tavares, 1999; p.464; Oliveira, 1972; p.46.
} 
América Latina. ${ }^{58}$ Apesar da não participação norte-americana no financiamento da industrialização nacional, Kubitschek desburocratiza e desonera as importações de bens de capitais por empresas estrangeiras e enquanto estratégia à ampliação de industrialização e, "nos cinco anos de seu mandato, todas as grandes marcas da indústria mundial tinham se estabelecido no Brasil" (Oliveira, 2018 [2006]; p.48). ${ }^{59}$ A associação ao capital estrangeiro neste momento destaca-se pelo fornecimento de tecnologia, central à manutenção de crescimento econômico. ${ }^{60} \mathrm{O}$ período JK não contempla inovação de cunho social. ${ }^{61} \mathrm{~A}$ migração campocidade intensifica-se. A população urbana amplia-se ainda mais, passa de $36 \%$ a $45 \%$ da população brasileira entre 1950 e $1960 .{ }^{62}$ A partir de 1958 dá-se a deterioração do salário mínimo real, deterioração esta agravada pós-1964. ${ }^{63}$ A crise que culmina no golpe de 1964 é dotada de caráter urbano. ${ }^{64}$

O início do regime militar é marcado por recessão econômica, associada à política de combate à inflação. A crise perdura até o ano de $1967.65 \mathrm{O}$ regime militar, contudo, defenderia a continuidade do crescimento nacional, com atuação fiscal e apoio a setores da economia, por exemplo. ${ }^{66}$ Para tal, seria necessário construir as condições para a ampliação e administração de recursos fiscais e financeiros, com vistas a superar os limites já tencionados no período Kubitschek. ${ }^{67}$

A defesa da industrialização como motor de crescimento indica continuidade, mas a forma de perseguir este objetivo, os instrumentos disponíveis e o poder do executivo federal de

\footnotetext{
${ }^{58}$ Oliveira, 1972; p.49. Segundo Tavares (1999; p.461): "A não ser com a tardia intervenção em Cuba, [...] a política externa norte-americana orientou-se para os velhos continentes, convertendo os seus inimigos da véspera Alemanha e Japão - em sócios preferenciais e desarmados da expansão da nova ordem econômica mundial e da Pax Americana".

${ }^{59}$ Tavares (1999; p.465) argumenta: "A entrada de capital financeiro externo no período 1950/70 foi insignificante; [...] e a expansão das filiais multinacionais deu-se sobretudo por reinvestimento dos lucros".

60 Oliveira, 1972; p.47;50.

61 Oliveira (2018 [2006]; p.49).

62 Taxa de urbanização brasileira segundo o Instituto Brasileiro de Geografia e Estatística (IBGE). Fonte: <https://seriesestatisticas.ibge.gov.br/>, consultado em julho de 2019.

63 Oliveira, 1972; pp.51-2.

${ }^{64} \mathrm{~A}$ não participação dos trabalhadores nos ganhos do desenvolvimento urbano-industrial é expressa pela piora de suas condições de vida, tendo este conflito se elevado à condição principal da crise de 1964 (Oliveira, 1972; pp.60-3). As reformas de base propostas pelo governo de João Goulart (1962-1964) são percebidas (Tavares, 1999; p.464). O tripé "populista" formado por sindicatos, industriais, latifundiários é abalado (Oliveira, 2018 [2006]; p.57).

${ }^{65}$ Oliveira, 1972; p.64.

${ }^{66}$ Lopreato, 2013; p.77.

${ }^{67}$ Lopreato, 2013; p.91.
} 
controlar e distribuir recursos [...] evidenciam nítidos traços de ruptura e o limiar de outra fase, marcada pela modernização do Estado e pela ampliação da capacidade financeira de intervenção (Lopreato, 2013; p.91).

Em 1964 é criado o Banco Central. A Lei 4.864 de 1965 cria medidas de estímulos à construção civil, incorporando incentivos tributários e isenção de impostos para preparações de blocos de concreto, por exemplo. ${ }^{68}$ A Lei 4.320 de 1964 padroniza o modelo orçamentário para as três esferas de governo no país, o Decreto-Lei № 200 de 1967 define o planejamento como atividade fundamental do governo federal e o orçamento-programa como um de seus instrumentos básicos, a Portaria № 9 de 1974 obriga a adoção da classificação de programas, projetos e atividades, reforçando a utilização do orçamento-programa pelos estados e municípios. ${ }^{69}$ Em 1966 é criado o fundo parafiscal instrumento histórico de financiamento da construção civil nacional, o FGTS. ${ }^{70}$ A reforma do sistema tributário em 1966 e o Al-5 centralizam a arrecadação de tributos. ${ }^{71}$ Em 1970 é criado o PIS-Pasep para financiar a grande empresa nacional via BNDES, novamente um fundo parafiscal. ${ }^{72}$ As cadernetas de poupança são revigoradas a partir da segurança aos juros reais, assumindo também a função de fonte de crédito habitacional capitaneado pelo Banco Nacional de Habitação (BNH). A ideia de subsídio ao valor dos serviços urbanos é abandonada, sendo as tarifas entendidas enquanto fonte de autofinanciamento das empresas públicas, a exemplo dos setores de energia e telecomunicações. ${ }^{73}$ A sofisticação de arquitetura institucional - o próprio aparato estatal - e o autoritarismo foram aproveitados para a ampliação de intervenção na economia e crescimento econômico, via política fiscal acompanhada por ampliação da carga tributária, empresas

\footnotetext{
68 Royer, 2009; pp.49-50.

69 Peres; Santos, 2018; pp.111-2. Os autores discutem os limites administrativos, legais e políticos à racionalização do processo orçamentário, assim como à adoção do orçamento-programa no país. O marco histórico à adoção do orçamento-programa no Brasil é o PPA 2000-2003, apenas possível após reformas administrativas implementadas na década de 1990. "[...] a classificação funcional-programática prevista na portaria anterior (№ 9/1974) tinha um problema estrutural ao estabelecer a uniformização de programas de todas as esferas de governo. [...] A portaria № 42/1999 modificou essa estrutura, padronizando funções e subfunções nacionalmente e permitindo a criação de programas próprios pelos entes federativos" (Peres; Santos, 2018; pp.113-4).

70 De natureza privada e sob gestão pública, a grandeza dos recursos do FGTS alçou o Banco Nacional da Habitação (BNH) "[...] à condição de segundo estabelecimento bancário do país de sua criação até o início dos anos 70 por conta da aplicação e liquidez dos recursos" (Royer, 2009; p.50).

${ }^{71}$ Lopreato, $2013 ;$ p.92.

72 Tavares, 1999; pp.465.

${ }^{73}$ Lopreato, 2013; p.94.
} 
estatais, crédito e fundos e programas do Banco Central. ${ }^{74} \mathrm{~A}$ entrada do capital financeiro internacional no período de 1950 a 1970 foi baixa, e o financiamento da produção dá-se especialmente por bancos nacionais, públicos e privados. ${ }^{75}$ De 1968 a 1973 todos os setores da economia expandiram-se fortemente, e o PIB apresenta média anual de crescimento de $11 \%{ }^{76}$ Em 1960, 90\% da população detinha $61 \%$ da renda, e 1\% detinha 11\%. Em 1970, 90\% da população detinha $51 \%$ da renda, e $1 \%$ detinha $17 \% .{ }^{77}$ A população urbana amplia-se de $45 \%$ a $56 \%$ da população brasileira entre 1960 e $1970 .^{78}$

A década de 1970 inicia-se com turbulências internacionais. A crise do petróleo acontece em $1973 .^{79} \mathrm{E}$ a política do regime militar de defesa do crescimento seria defrontada pela economia internacional, e em seguida abandonada pelo setor industrial nacional. ${ }^{80}$ Com destaque ao período Geisel (1974-1979), o regime militar utiliza o capital financeiro externo para financiar a infraestrutura, a expansão das estatais e conceder financiamento público barato com vistas ao aumento de escala da indústria pesada no país. Por um lado, o reforço às indústrias apoia-se no fundo de poupança compulsória, por outro submete a autonomia de estatais ao endividamento externo do Estado. ${ }^{81}$

A partir de Decreto-Lei de 1969, e em associação à grandeza de investimentos públicos, a realização de projetos e obras de infraestrutura são realizadas exclusivamente junto a empresas brasileiras, de capital nacional, com sede e registradas no país. ${ }^{82}$ "[...] lideravam o orçamento federal as verbas sob o controle do Ministério dos Transportes e do Ministério de Minas e Energia [...], na forma principal de inversões para a realização de obras rodoviárias e empreendimentos na área de eletricidade, com ênfase na construção de grandes usinas

\footnotetext{
${ }^{74}$ Lopreato, 2013; pp.97-8;114-5.

75 Tavares, 1999; p.465.

76 Oliveira, 2018 [2006]; p.59.

77 Oliveira, 1972; pp.66-7.

78 Taxa de urbanização brasileira segundo o Instituto Brasileiro de Geografia e Estatística (IBGE). Fonte: <https://seriesestatisticas.ibge.gov.br/>, consultado em julho de 2019.

79 Paulani, 2012; p.91.

${ }^{80}$ Qualquer queda no investimento estatal afetaria mais que proporcionalmente o empresariado nacional (Tavares, 1999; p.469).

81 Tavares, 1999; p.469.

${ }^{82}$ Campos, 2018; p.351.
} 
hidrelétricas [...]" (Campos, 2018; p.352). O período também é marcado por investimentos em habitação, mobilidade e saneamento básico. ${ }^{83}$

A alta da taxa de juros norte-americana e o segundo choque do petróleo acontecem em 1979. A "diplomacia" do dólar forte multiplicou por três a dívida externa brasileira, e conduziu o planeta à crise de $1980-1982 .{ }^{84}$ Abre-se espaço a questionamentos sobre a expansão dos gastos e ativismo fiscal estatal no país. É inviabilizada a política militar de defesa do crescimento. A inflação e o balanço de pagamentos são a nova "ordem do dia". ${ }^{85}$ A queda da atividade econômica e a aceleração inflacionária nacional apontam para o aumento do déficit e da dívida pública. É evidenciada a insuficiência do "capitalismo monopolista de Estado" frente à condução de crescimento sustentado de base nacional no Brasil de então. ${ }^{86}$

[...] o sonho da grande potência transformou-se em fracasso, às vésperas da reafirmação completa da hegemonia americana e do começo da nossa transição democrática lenta, gradual e insegura. $O$ fracasso deu-se menos pelo território e mais pelo dinheiro e sobretudo pelo Império, já que enfrentou em simultâneo as contradições internas de seu sistema militar, da sua aliança com a 'burguesia nacional' e da sua tentativa de desfiliação ao sistema imperial americano (Tavares, 1999; 474).

A década de 1980 é conhecida como a "década perdida". O ano de 1979 sinaliza um período de 15 anos de elevada inflação no Brasil, contornada apenas a partir do Plano Real, em 1994. O país é parte da crise da dívida externa, em 1987 o Brasil entra em moratória. ${ }^{87}$

Em termos econômicos, 1979-1980 tratar-se-ia de inflexão após intensa trajetória do "desenvolvimento tardio de forças produtivas capitalistas" no país, para utilizar a expressão de Tavares (2009). Este momento é, assim, estratégico à compreensão do produto urbano de nosso desenvolvimento. A população urbana amplia-se de $56 \%$ a $68 \%$ da população brasileira entre 1970 e $1980 .{ }^{88}$ O Brasil de 1980 apresenta-se enquanto urbano e industrial.

\footnotetext{
${ }^{83}$ Maricato; Royer, 2017; p.148; Bolaffi, 1975; p.53.

84 Tavares, 1999; p.474.

85 Lopreato, 2013; pp.117-8.

86 Tavares, 1999; p.468.

87 Paulani, 2012; p.92.

88 Taxa de urbanização brasileira segundo o Instituto Brasileiro de Geografia e Estatística (IBGE). Fonte: <https://seriesestatisticas.ibge.gov.br/>, consultado em julho de 2019.
} 
A industrialização teria de ser urbana. ${ }^{89}$ A concentração espacial das atividades econômicas traz vantagens financeiras, comerciais e produtivas, e em termos de custos de infraestrutura, serviços básicos e serviços financeiros. À medida em que as empresas se concentram, seus mercados também se ampliam. A concentração industrial viabilizou a expansão terciária e de serviços. ${ }^{90}$ O estado de São Paulo chega a concentrar $35,6 \%$ da renda interna do Brasil em 1969, e cerca de 19\% da população brasileira. O rendimento do habitante de São Paulo chega a ser duas vezes maior em comparação ao resto do país, e 40\% da renda interna paulista é então proveniente da indústria. A economia de aglomeração viabiliza o menor custo da energia elétrica, transporte, água, esgoto. Contudo, as condições de vida na cidade não melhoram em acordo com o crescimento econômico. ${ }^{91}$

Em 1950, 61\% da população da região metropolitana de São Paulo conta com abastecimento de água, e em 1973 o índice cai para 56\%. Em 1950, 35\% da população da região metropolitana de São Paulo conta com coleta de esgoto. O índice mantém-se em $1973 .{ }^{92}$ Vale resgatar, o poder aquisitivo do assalariado cai 36,5\% entre 1958 e 1969. 50\% população brasileira apropriou 16,7\% da renda nacional em 1960. Em 1970 a proporção cai para 13,1\%. ${ }^{93}$ Em 1970, 52\% da população conta com rendimento de até 1 salário mínimo. ${ }^{94}$ Tomando como referência a década de 1970, 81\% das moradias são construídas pelo proprietário sozinho, ou pelo proprietário acompanhado por amigos e familiares no município industrial de São Bernardo do Campo. ${ }^{95}$ Os baixos salários de então não suportam nem as despesas com aluguel, sendo a compra do imóvel impraticável pela maior parte da população. Permanecem, contudo, a terra (quando comprada), os materiais da construção, a mão-de-obra (quando contratada) e técnica construtiva a cargo do rendimento salarial; O improviso, a não associação aos serviços urbanos, e a extensão em tempo são faces da autoconstrução da casa própria, mas também de igrejas, escolas, creches, centros comunitários, por exemplo. ${ }^{96}$

\footnotetext{
89 Oliveira, 1982; p.42.

90 Singer, 1973; pp.123-4.

${ }^{91}$ Camargo et al., 1975; pp.13-4;16-7; Kowarick, 1993 [1979].

${ }^{92}$ Camargo et al., 1975; pp.22-3;36;47.

${ }^{93}$ Maricato, 1979; p.81.

${ }^{94}$ Camargo et al., 1975; p.65.

95 Maricato, 1979; p.74.

${ }^{96}$ Maricato, 1979; pp. 77-9; 84-6; 93.
} 

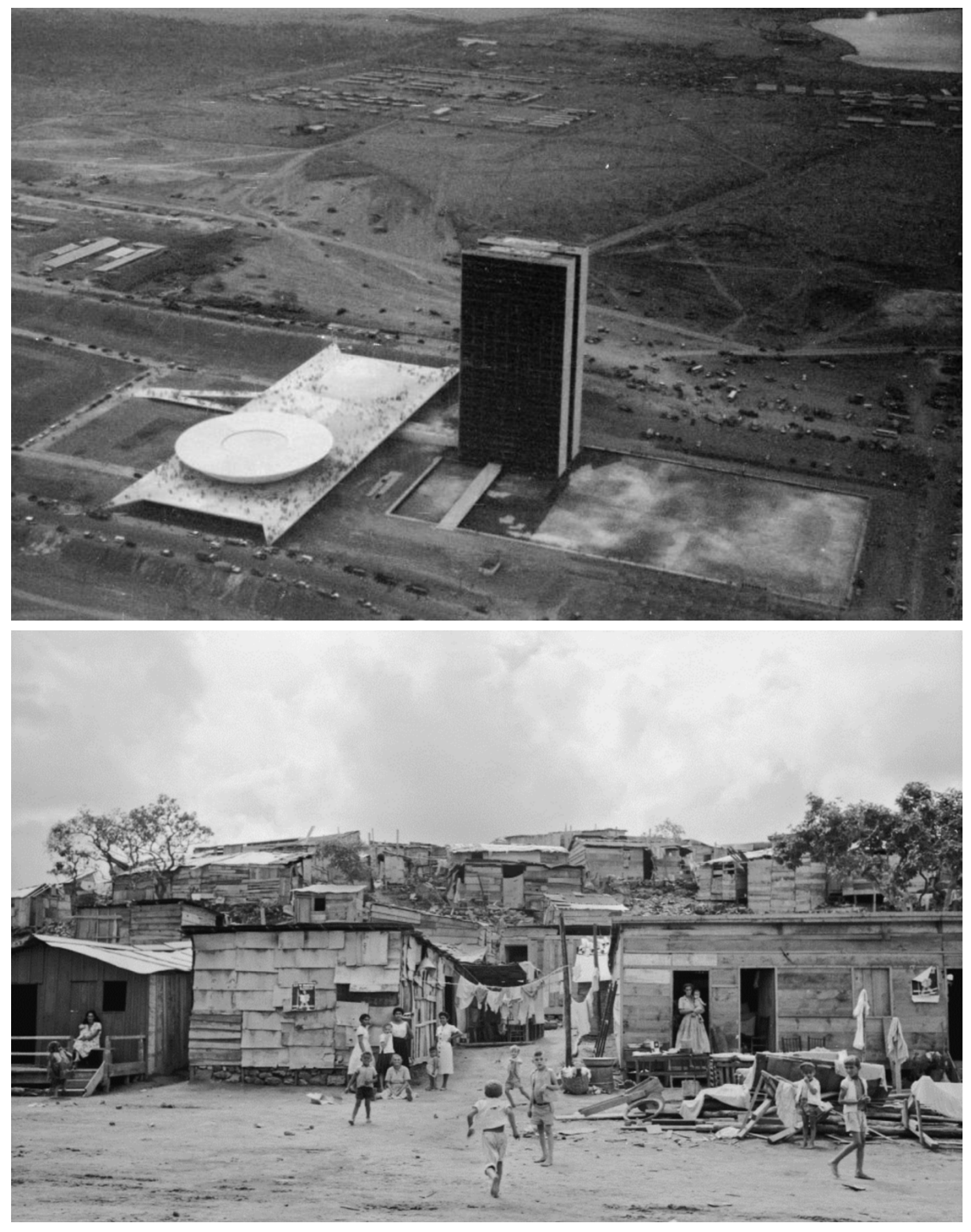

Imagem 1.1.1 e 1.1.2: Thomaz Farkas retrata a construção de Brasília em 1960. Foto "Vista de Brasília". Thomaz Farkas retrata a autoconstrução do entorno de Brasília em 1959, ainda antes da inauguração da nova capital. Foto "Núcleo Bandeirante". Imagens extraídas de Sampaio (2016). ${ }^{97}$

${ }_{97}$ As fotos compõem acervo de Instituto Moreira Salles. Algumas fotos, tanto de Brasília quanto das cidades satélite, podem ser consultadas em Sampaio (2016). 
Apresenta-se a industrialização nacional e a produção das metrópoles brasileiras, sendo estas concentradoras das necessidades e precariedades urbanas e habitacionais do país. ${ }^{98}$ Verifica-se crescimento populacional em centros urbanos do centro-oeste e norte brasileiros, a exemplo de Goiânia, Brasília, Manaus e Belém do Pará, alheios à tradicional ocupação territorial nacional, esta associada às regiões sul, sudeste e nordeste. A literatura especializada, no entanto, procurou diferenciar os processos de urbanização no país. A urbanização com baixos salários conceituada por Maricato a partir do conceito de industrialização com baixos salários não é um fenômeno social e econômico homogêneo no país.

Em Recife o urbano precede a indústria. ${ }^{99} \mathrm{Em}$ Salvador há "urbanização sem industrialização", cidade de marcada pobreza e deprimida economicamente desde finais do XIX. É durante a década de 1960 que se verifica a expansão econômica e produtiva no Nordeste brasileiro. ${ }^{100} \mathrm{~A}$ expansão econômica nordestina está associada ao aporte de recursos da União por meio de empresas estatais - incluídas a Petrobrás, Eletrobrás, Siderbrás, Telebrás e Vale do Rio Doce; incentivos fiscais concedidos pela Sudene; isenções concedidas por governos estaduais e municipais; acessos a recursos na forma de participação acionária através BNDES e Banco do Nordeste do Brasil (BNB); financiamentos BNDES e BNB; financiamentos BNH e Banco Mundial para infraestruturas industrial e de saneamento. A estratégia de expansão econômica nordestina espelha políticas nacionais, mas assume particularidades. A dedução de imposto de renda é exclusividade inicial do Nordeste, logo após estendida a regiões específicas, a exemplo da Amazônia. ${ }^{101}$ Assumidas as particularidades regionais e locais do Nordeste e de Salvador, verifica-se associada expansão econômica e produtiva, fortalecimento de crescimento populacional e marginalização de população. ${ }^{102}$ Não se trata de um processo espontâneo, mas

\footnotetext{
98 Marques, 2014; 2015; Pasternak; D’Ottaviano, 2016. Verificar seção 1.3.1 da presente dissertação.

99 Oliveira, 1982; p.38.

100 Oliveira, 1980 [1979].

101 Oliveira, 1980 [1979]; 1990; pp.70-1;74.

102 Verificar Souza e Faria (org.), 1980.
} 
socialmente conflituoso, ${ }^{103}$ associado a uma atuação estatal. ${ }^{104}$ A urbanização do país se desenvolve ininterruptamente ao longo das décadas (Gráfico 1.1.1).

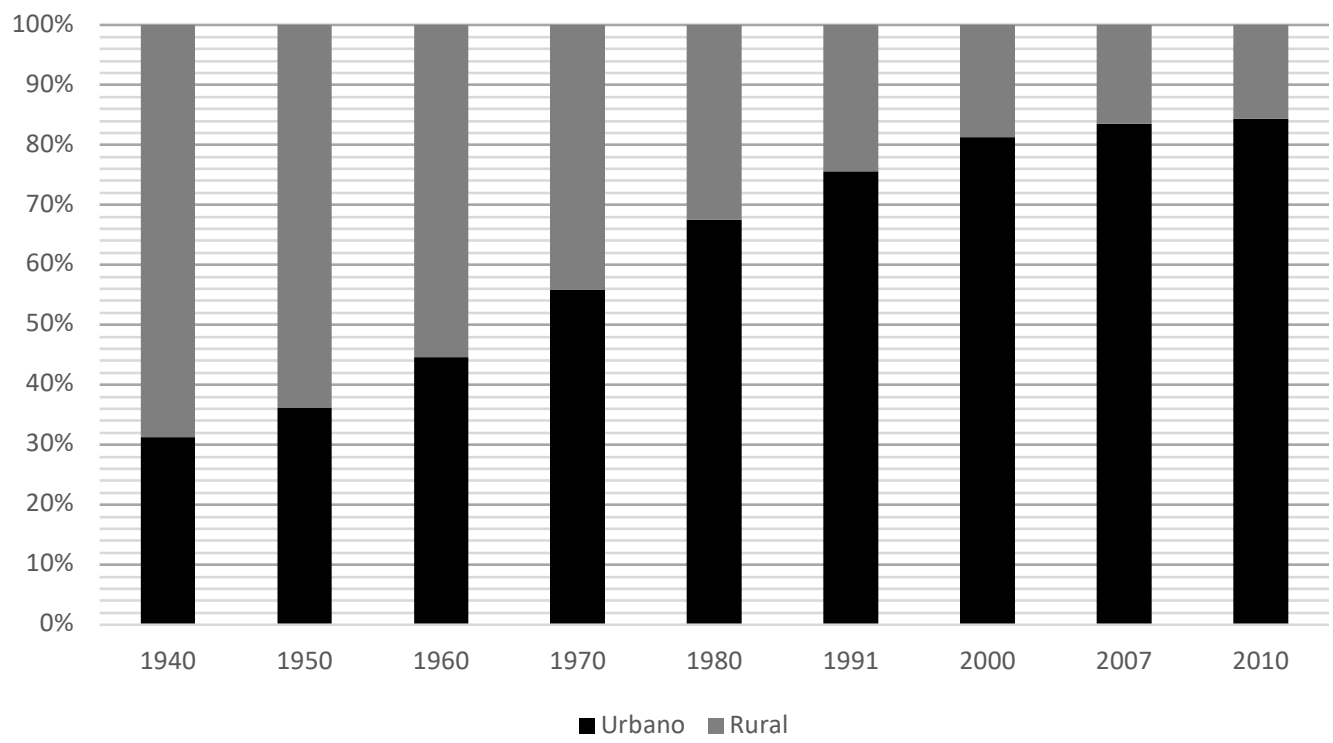

Gráfico 1.1.1: Taxa de urbanização brasileira. Fonte: Séries estatísticas IBGE. ${ }^{105}$

Entre a década de 1970 e a virada para o século XXI, contudo, se verifica a desindustrialização nacional, reprimarização da exportação e retomada de fortalecimento de economia agrário-exportadora. ${ }^{106}$ Entre 1970 e 1991, ainda que muito concentrada nos grandes centros urbanos, há reversão da polarização populacional e as cidades médias assumem relevância, sendo as cidades médias aquelas com população entre 50 e 500 mil habitantes. Entre 1970 e 1991 a população para o conjunto dos municípios médios é elevada em 8,3\%. ${ }^{107}$

103 O desenvolvimento urbano está associado a processos econômicos. Como menciona Francisco de Oliveira, os processos econômicos são "violentos", assumido aqui enquanto conflituoso. Na ocasião, o pensador refletiu sobre a redução da miséria e pobreza durante os primeiros anos do século XXI no país, e suas possíveis relações com conflitos sociais evidenciados especialmente a partir de 2013. Verificar entrevista realizada ao programa Roda Viva da TV Cultura em 30 de dezembro de 2013, minuto 49. Disponível em: <https://www.youtube.com/watch?v=fFhGyhr0-8>, consultado em julho de 2019.

${ }^{104}$ Como disse Francisco de Oliveira: "O DNA do desenvolvimento brasileiro é estatal". Inclusive, o pensador se refere a isto enquanto uma conquista. A expressão advém de debate sobre concessões de serviços e infraestrutura pública. O debate é construído a partir de fala de economista Paul Singer que abarca a ideia de "greve de investimentos". Verificar debate e entrevista realizada ao programa Roda Viva da TV Cultura em 30 de dezembro de 2013, por volta de minuto 60 a 65. Disponível em: <https://www.youtube.com/watch?v=fF-hGyhr0-8>, consultado em julho de 2019.

105 Extraído de: <https://seriesestatisticas.ibge.gov.br/series.aspx?no=10\&op=0\&vcodigo=POP122\&t=taxaurbanizacao>.

106 Paulani (2012).

${ }^{107}$ Andrade; Serra, 2001; p.133-4. 
Esse dinamismo está associado a "[...] a mudanças recentes nos padrões locacionais da indústria; as transformações mais visíveis no movimento migratório nacional; o fenômeno da periferização das metrópoles; a política governamental de atração de investimentos para as regiões economicamente defasadas; e a peculiar expansão de nossas fronteiras agrícolas e de extração de recursos minerais". ${ }^{108}$

A associação entre inserção econômica internacional e a resolução dos conflitos internos à sociedade apontará os desdobramentos para o novo século. O que já deve ser percebido, no entanto, é um certo desvio em torno do urbano nacional, cada vez mais expressivo nas cidades médias, produtos e produtoras de formas novas políticas, econômicas e sociais.

De modo geral, destaca-se a importância dos fluxos de riqueza nacional e internacional, da associação entre processos internacionais e nacionais, da própria estrutura social, política, e econômica nacional historicamente verificada, e da economia política da urbanização ${ }^{109}$ para a compreensão do fenômeno urbano brasileiro. Atualmente, a maioria da população brasileira vive em cidades, e desenvolve suas atividades em associação às infraestruturas habitacional e urbana, produtos e produtores de processos sociais.

\subsection{Desenvolvimento urbano, a estruturação e arranjos da atuação estatal ${ }^{110}$}

\subsubsection{Estruturação da atuação estatal}

Em associação à solidariedade popular forçada, ${ }^{111}$ as demandas pelo acesso ao abastecimento de água, esgotamento sanitário, e mobilidade urbana são formuladas, entendendo-se o Estado enquanto principal responsável por suas resoluções e por meio da

\footnotetext{
108 Andrade; Serra, 2001; p.133.

109 Nos termos de Singer, 1980 [1973].

110 O subcapítulo 1.2 incorpora a continuidade, em termos de história econômica brasileira, de subcapítulo 1.1. O título confere maior destaque ao "caminho", e menor destaque às "pedras". Contudo, as pedras constrangem o caminho, tal como parece insinuar Drummond.

${ }^{111}$ Maricato, 1979; pp.72-3.
} 
riqueza pública. ${ }^{112}$ Há a estruturação da atuação estatal em torno do desenvolvimento urbano, também com vistas à resolução do problema urbano no país. ${ }^{113}$

Durante as décadas de 1930 e 1940, as cidades brasileiras crescem diante da ausência quase que completa de políticas públicas urbanas e habitacionais, e a década de 1960 é marcada pelo acúmulo de precariedades e ausência de estruturas estatais relativas a esse problema. ${ }^{114} \mathrm{O}$ não acesso a serviços básicos urbanos (abastecimento de água, esgotamento sanitário, e energia elétrica) é generalizado para o território nacional na década de $1970 .{ }^{115}$ É a este cenário, somado à autoconstrução da casa por maioria da população brasileira, a qual nos referimos enquanto o "problema urbano". Diante desse cenário, mesmo que durante o regime militar autoritário, a década de 1970 confere espaço a manifestações urbanas populares, preocupadas em questionar a qualidade dos serviços nas cidades brasileiras. ${ }^{116}$

Durante o regime militar são implementadas massivas políticas centralizadas relativas à habitação e saneamento básico. É o caso do Banco Nacional da Habitação (BNH) (1964), Sistema Financeiro da Habitação (SFH) (1964), Fundo de Financiamento para o Saneamento (Fisane) (1967), formulação do Plano Nacional de Saneamento Básico (Planasa) (1971), e as políticas

\footnotetext{
112 Singer, 1980; pp.117-33.

113 Historicamente, o desenvolvimento urbano se associa à construção de um modo de regulação-regime de acumulação no Brasil do século XX.

A administração pública, atuação estatal, Estado ou instituições tanto associam-se à condução de expansão econômica e de forças produtivas no país, quanto à resolução de conflitos intrínsecos à subordinação do trabalhador. É medular a atuação estatal frente ao desenvolvimento econômico nacional, e este desenvolvimento teria de ser urbano. Por um lado, a atuação estatal é economicamente central à industrialização e urbanização no Brasil. Por outro lado, a resolução do problema urbano é politicamente formulada nas cidades, processualmente, assumindo-se a atuação estatal enquanto alternativa social. Nos termos de Boyer (2009; p.52), denota-se a interdependência entre formas institucionais e o papel do Estado enquanto expressão da imbricação entre esferas política e econômica.

Sugere-se assim a força explicativa da teoria da regulação para a compreensão da associação entre desenvolvimento urbano, desenvolvimento econômico e de forças produtivas, e a própria sofisticação institucional e de atuação estatal no Brasil. Avançar teoricamente exige o aprofundamento sobre as formas institucionais: regime monetário; forma de concorrência; relação salarial; natureza do Estado; e inserção no regime internacional, conforme apresentado por Boyer. A teoria da regulação menos contribui ao entendimento sobre a agência, ou sobre os fenômenos políticos, e mais sobre dinâmicas históricas. "A teoria da regulação trata das tendências a longo prazo" (Boyer, 2009; p.79). De qualquer modo, a teoria da regulação contempla a variedade dos modos de regulação e regimes de acumulação: "Os compromissos institucionalizados fundamentam as formas institucionais" (Boyer, 2009; p.65).

114 Marques, 2015; p.225.

115 Arretche, 2015; p.195.

116 Maricato, 1988.
} 
implementadas via o Serviço Federal de Habitação e Urbanismo (Serfhau). ${ }^{117}$ O Fundo de Garantia do Tempo de Serviço (FGTS) e o Sistema Brasileiro de Poupança e Empréstimos (SBPE) configuram, a partir de então, referências centrais ao financiamento da infraestrutura urbana e habitacional no país. Sob a regulação do SFH, o BNH recebe a gestão dos recursos do FGTS em 1967; em 1968 há a regulamentação das cadernetas de poupança privada a partir do Conselho Diretor do BNH, os recursos do SBPE são administrados pelo sistema bancário público e privado no país. O FGTS assume, historicamente, um maior compromisso com as rendas mais baixas e em torno das políticas de habitação e saneamento. O SBPE concentra-se sobre a renda média e financiamento habitacional. ${ }^{118}$

Entre 1972 e 1976 uma série de programas é criada pelo BNH, um esforço de financiamento das infraestruturas urbanas e de concessão de empréstimos a estados, municípios e companhias de saneamento. ${ }^{119}$ Nesse momento conjuntos habitacionais já haviam sido concluídos e habitados sem ainda dispor do acesso a infraestrutura e serviços urbanos, o caso do distrito de Cidade Tiradentes, extremo leste do município de São Paulo, é emblemático. $^{120}$

117 Bolaffi, 1975; Marques, 2015; pp.225-7; Kuhn, 2018; pp.26-7.

A criação do Banco Nacional da Habitação e órgãos correlatos busca promover a aquisição da casa própria especialmente pelas populações de baixa renda; mas também a coordenação da política habitacional; financiamento de infraestruturas de saneamento básico; melhoria do padrão habitacional e ambiental - eliminação das favelas; redução do preço da habitação pela produção em escala industrial; melhoria das condições sanitárias da população; redistribuição regional dos investimentos brasileiros; estímulo à poupança privada e investimentos; ampliação da eficiência dos investimentos públicos estaduais e municipais; aumento dos investimentos nas indústrias do setor da construção para o atendimento das demandas vegetativas e de reposição; aumento da oferta de emprego; criação de polos de desenvolvimento com a consequente melhoria da condição de vida em áreas rurais (Bolaffi, 1975; p.77).

Até o ano de 1980, o Planasa (1971) objetiva o atendimento de $80 \%$ da população por serviços de abastecimento de água, e 50\% da população por serviços de coleta de esgotos sanitários (Kuhn, 2018; pp.26-7).

118 Royer, 2009; p.46; Cardoso; Aragão, 2013; pp.17-8.

119 Royer (2009; pp.47-68) apresenta diferentes fases da trajetória SFH, SBPE e FGTS, desde sua criação ao Plano Real. Demonstra como, mesmo durante regime autoritário, a construção, a operação ou trajetória dessas robustas instituições não é linear ou alheia a disputas.

120 Souza, 2014. As imagens apresentadas por Souza ilustram os descompassos entre a provisão das infraestruturas urbana e habitacional durante o período $\mathrm{BNH}$. 

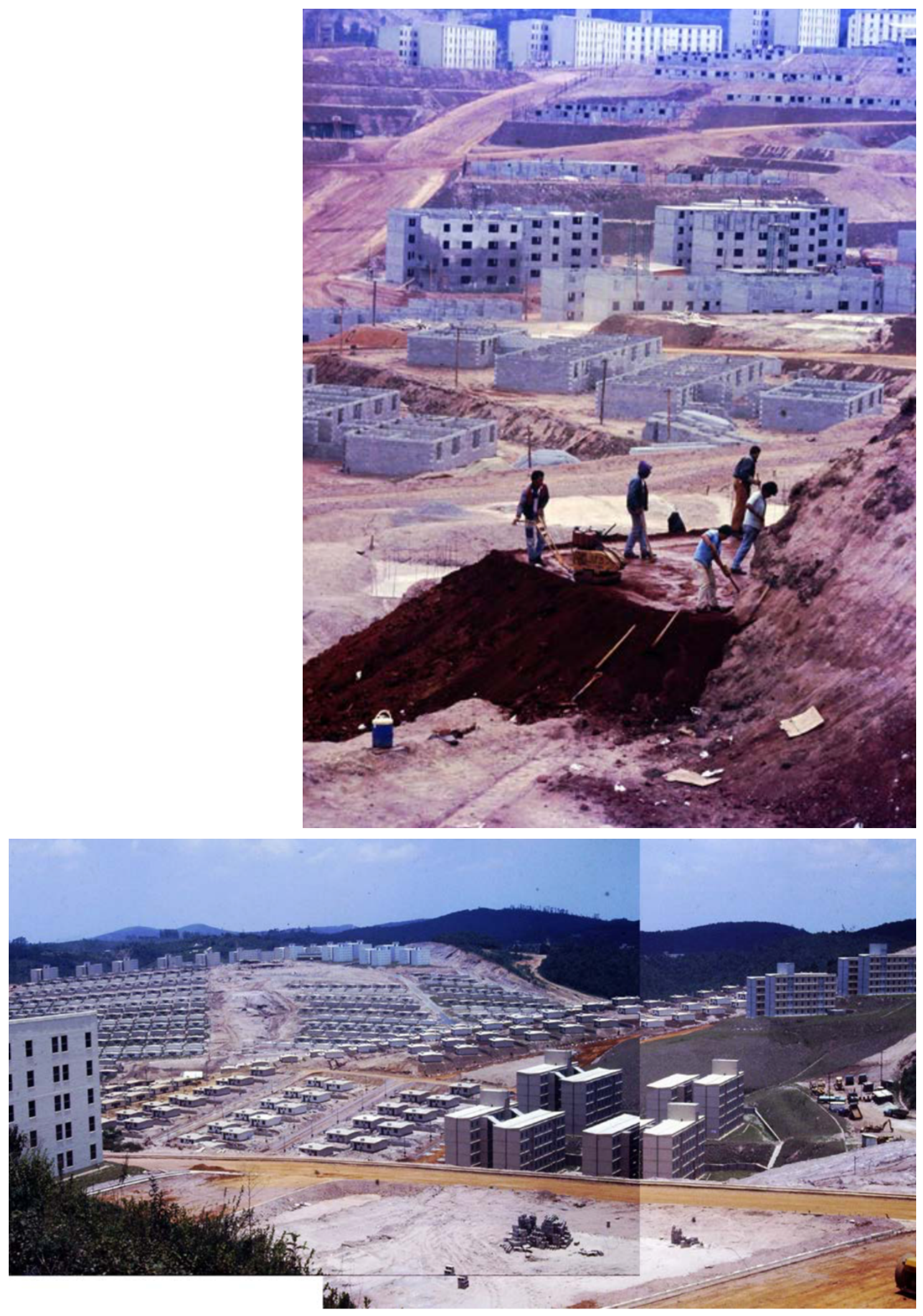

Imagem 1.2.1.1 e 1.2.1.2: Construção de grandes conjuntos habitacionais no extremo leste do município de São Paulo. Acervo CDTec Cohab-SP. Imagens extraídas de Souza (2014). 
Por meio do $\mathrm{BNH}$, a esfera federal tanto atende a demanda privada por crédito de longo prazo, como fortalece a intervenção do setor público. Os “[...] estados e municípios transformaram em empresas as unidades historicamente identificadas com a administração direta (transporte, saneamento, habitação e outras), com o intuito de ter acesso às linhas de financiamento federais" (Lopreato, 2013; p.111). Essa atuação articula o fiscal e o financeiro frente às fontes de financiamento, beneficia empresas estatais e governos subnacionais e, ao mesmo tempo, reforça a capacidade do governo central em direcionar os investimentos em habitação e saneamento via repasses financeiros condicionados. ${ }^{121}$

O SFH financia a construção de aproximadamente 4,45 milhões de unidades habitacionais entre 1964 e 1986, o que representa o financiamento de cerca de $25 \%$ das novas unidades habitacionais no país durante esse período. A construção das demais unidades habitacionais é autofinanciada ou autoconstruída. Das 4,45 milhões de unidades habitacionais financiadas pelo $\mathrm{SFH}, 33,1 \%$ foram destinadas a faixas de renda de 1 a 3 salários mínimos. ${ }^{122}$

Mesmo que expressivas, as políticas do regime militar não são capazes de superar o problema urbano. A associação entre desenho institucional, agência privada e economia política da urbanização denota os limites aos gastos durante o regime militar. Para além da importante alocação de recursos financeiros em obras de infraestrutura urbana, ${ }^{123}$ verificam-se limites ao atendimento dos mais pobres pelo investimento público, ao menos durante os primeiros anos da ditadura:

Segundo o relatório anual do BNH de 1971 "os recursos utilizados pelo Sistema Financeiro da Habitação só foram suficientes para atender a $24 \%$ da demanda populacional (urbana)." Isto significa que, seis anos após a criação do BNH, toda sua contribuição para atender ou diminuir o déficit que ele se propôs eliminar consistiu em que esse mesmo déficit aumentasse em 76 por cento" (Bolaffi, 1975; p.78).

\footnotetext{
${ }^{121}$ Lopreato, 2013; pp.107-8. “A União recorreu a diferentes mecanismos: transferências vinculadas, repasses das instituições oficiais de crédito, convênios, crédito a áreas específicas e gastos diretos, como meio de direcionar as despesas de estados e municípios e torná-las compatíveis com o projeto oficial. Os governos subnacionais, por sua vez, perderam autonomia em matéria de política fiscal e tributária, além do poder de sustentarem níveis crescentes de gastos com recursos próprios [...]" (Lopreato, 2013; p.110).

122 Royer, 2009; pp.62-4; Silva; Tourinho, 2015; p.402.

${ }^{123}$ Campos, 2018; pp.352-3.
} 
De qualquer modo, o Planasa, a criação da Eletrosul (1968), a Eletronorte (1973) e a Itaipu binacional contribuem à expansão do acesso aos serviços urbanos básicos durante o regime militar. ${ }^{124}$

O boom da economia mundial encerra-se na década de 1970, o monetarismo assume a posição de paradigma teórico econômico, e o ativismo fiscal perde espaço. O domínio da política monetária, ou monetarismo, exige a revisão de aparato institucional em associação ao controle do gasto público e dos incentivos fiscais e creditícios no Brasil. A disputa teórica no campo das ciências econômicas expressa a dificuldade em torno da questão fiscal, e representa resistência às reformas institucionais propostas durante a década de 1980 no país. De qualquer modo, o combate à inflação e déficit público assume centralidade, e sinaliza uma nova conduta da política fiscal. O acordo de assistência financeira do FMI assinado em 1982 define o ajuste fiscal enquanto núcleo da política macroeconômica. ${ }^{125} \mathrm{~A}$ crítica sobre a concentração da receita tributária e da gestão da crise pelo governo central, e sobre a consequente perda de autonomia dos governos subnacionais na condução dos investimentos ou na resolução dos impasses financeiros por estados e municípios, também ganha força. ${ }^{126}$

Desse modo, uma série de fatores articula-se à crise das políticas de habitação e saneamento do regime militar, assumindo como marco a extinção do Banco Nacional da Habitação em 1986. Os fatores são de ordem econômica-política nacional e internacional, mas também elementos da resolução de conflitos da sociedade nacional. O choque de juros de 1979, o aprofundamento do país na crise da dívida externa, o colapso do mercado de crédito internacional em 1982 com implicações sobre a entrada de capitais autônomos no país, a

\footnotetext{
${ }^{124}$ Arretche, 2015; p.211.

125 Lopreato, 2013; pp.117-20; 129-31.

Fiori (2004; pp.9-14) resgata, no prefácio da reedição da tese sobre o voo da coruja, as dimensões históricas da crise do Estado desenvolvimentista e do "desenvolvimentismo conservador" brasileiro no início e durante a década de 1980. Para Fiori, a crise do Estado desenvolvimentista é (também) expressão das disputas entre três projetos para o Brasil: o projeto liberal de inserção internacional da elite cafeeira e agrário-exportadora; o segundo projeto é o desenvolvimento conservador liderado pelos industrialistas (termo do autor); o terceiro projeto é o de desenvolvimento econômico nacional e popular, ora sintetizado por Furtado em 1963, ora manifesto na luta contra o regime militar e construção da Constituição de 1988. Os três projetos enfrentam-se ao longo de todo o século XX. Segundo o autor, o embate entre projetos elucida tanto a desmontagem de Estado desenvolvimentista durante a década de 1990, como significados de eleições presidenciais de 2002.

${ }^{126}$ Lopreato, 2013; p.127; 144-5.
} 
escassez dos recursos financeiros estatais e a moratória de 1987, a crise inflacionária, a queda dos salários e inadimplência decorrente, a informalização da economia, a queda da arrecadação e ampliação dos saques do FGTS, a crise do regime militar e a tentativa de superação das suas políticas são faces da extinção do BNH. ${ }^{127}$ Sem o BNH as companhias estaduais de habitação também enfrentam a crise, agora em situação de insolvência. ${ }^{128}$ Segundo Tavares (1999; p.474), a solução via fundos parafiscais aponta a precariedade da articulação entre capital nacional e financiamento público e privado. Cabe retomar, o período JK já havia explicitado a necessidade de revisão do sistema de financiamento do setor público, e as poupanças compulsórias responderam em parte a este problema. ${ }^{129} \mathrm{O}$ enfraquecimento do financiamento interno e o reescalonamento da dívida, assim como a própria crítica à intervenção estatal e seus instrumentos fiscais e financeiros, significam fortes restrições às políticas de habitação e saneamento do regime militar.

\subsubsection{Rearranjo da atuação estatal}

A década de 1990 inicia-se com o Plano Collor que, apesar de inovar ao adotar a liquidez monetária como causa central da inflação brasileira, do bloqueio dos ativos financeiros e do combate ao déficit via aumento da arrecadação e redução estatal, por exemplo, demonstra-se limitado à estabilização da economia brasileira. É, na verdade, o acordo de renegociação da dívida externa que possibilita a evolução da situação econômica nacional, sendo a renegociação iniciada durante o governo Collor, e estendida até 1994, governo Itamar Franco.

O país passou a ter condições de adotar um programa de estabilização baseado na âncora cambial, a exemplo do que outros vizinhos da América Latina já haviam feito com sucesso, após concluírem a renegociação da dívida externa. A exigência de sustentar a âncora cambial dependia da atração do capital necessário à cobertura do déficit em transações correntes, com a oferta de um rol de ativos de alta taxa de retorno e garantia de valorização. As privatizações, a abertura do mercado bancário, as fusões e incorporações de empresas e os lucros na bolsa de valores, bem como as aplicações em títulos da dívida pública, com ativos em condição de ganho e liquidez compatíveis com a expectativa do mercado, cumpriram esse papel [...] (Lopreato, 2013; p.164).

\footnotetext{
127 Royer, 2009; pp.58-60; Paulani, 2012; pp.91-2; Tavares, 1999; pp.469; 474-77; Cardoso; Aragão, 2013; pp.18-9; Lopreato, 2013; p.115.

${ }^{128}$ Cardoso; Aragão, 2013; p.23.

${ }^{129}$ Lopreato, 2013; pp.93-4.
} 
Respaldado pelo Plano Real, o governo de Fernando Henrique Cardoso avança sobre a revisão do modelo de desenvolvimento nacional capitaneado pelo Estado. Por um lado, as medidas governamentais orientam-se à redução da participação estatal na produção e investimentos em infraestrutura e privatização de empresas públicas. Por outro lado, a revisão do regime fiscal e a promoção do ajuste fiscal permanente seria a estratégia ao convencimento global a respeito do controle intertemporal das contas públicas brasileiras. É no governo de Fernando Henrique Cardoso que, diante do baixo endividamento federal e conjuntura externa favorável, em associação ao suporte do Congresso, governadores, e prefeitos, dá-se a reformulação do papel do Estado e a construção de um novo regime fiscal brasileiro. A memória da crise dos anos 1980 dilapida a oposição a essas reformas governamentais. O controle da inflação evidencia a crise fiscal dos municípios e estados, acentuando assim a dependência subnacional ao governo federal. ${ }^{130}$

"A revisão do padrão de intervenção do Estado na economia constitui-se no pilar da mudança do regime fiscal" (Lopreato, 2013; p.178). As privatizações, o fim dos sistemas e holdings estatais e a tendência de transformação do BNDES em banco de investimentos exemplificam esse processo. A construção do novo regime fiscal afeta o federalismo fiscal, a elaboração orçamentária, o controle e as regras fiscais do endividamento. A articulação entre empresas federais e correlatas estaduais construída pelo regime militar é eliminada, com impactos sobre políticas setoriais, distribuição dos investimentos e administração dos recursos no país. A renegociação das dívidas dos governos subnacionais em 1997 busca promover o ajuste entre endividamento e capacidade de pagamento, mas também aponta a venda de bancos e empresas pelo setor público. ${ }^{131}$

As Leis Rita Camata I e II, estabelecidas em 1995 e 1999, ampliam o controle sobre o déficit e dívidas públicas, com destaque ao controle das despesas com pessoal. Também foram dedicados esforços às dívidas mobiliária, flutuante e originária de precatórios do setor público, assim como a ajustes previdenciários. Os esforços de controle dos déficits e dívidas são consolidados pela Lei Complementar das Finanças Públicas - Lei № 101 de 2000, a Lei de

\footnotetext{
130 Lopreato, 2013; p.165-6.

131 Lopreato, 2013; pp.177-80.
} 
Responsabilidade Fiscal (LRF). A LRF corrobora a dependência dos entes subnacionais frente ao governo federal. ${ }^{132}$

Para além do controle financeiro das contas públicas, cabe avaliar o processo orçamentário. A Constituição de 1988 já havia obrigado a aprovação legislativa do Plano Plurianual de Ações (PPA), Lei de Diretrizes Orçamentárias (LDO) e Lei Orçamentária Anual (LOA) para os entes da federação, peças legais elaboradas pelo poder executivo e responsáveis pelo estudo e definição das receitas e despesas públicas no país. As leis orçamentárias são autorizativas: permitem, mas não obrigam o gasto público. No ano de 1999 verifica-se importante reordenamento do processo orçamentário, com destaque às mudanças na classificação das despesas. A Portaria № 42 de 1999 padroniza funções e subfunções orçamentárias a nível nacional, e permite a criação de programas por todos os entes federados. Efetiva-se, assim, a separação entre classificações programática e funcional, viabilizando o orçamento-programa no país, um esforço que remonta ao regime militar. O Plano Plurianual (PPA) 2000-2003 federal, aprovado em 2000, é um marco no processo orçamentário do país, modelo baseado em programas estruturados por ações e dotados de custos e indicadores de resultados, desempenho e gestão. Em 2001 os Ministérios da Fazenda e do Planejamento estabelecem o controle das receitas e despesas por fonte. Essas alterações no processo orçamentário significam inegáveis ganhos ao controle das finanças públicas, inclusive em termos de controle social, ainda que se mostre necessário o debate sobre a associação entre LRF e o processo orçamentário no país: ${ }^{133}$

[...] com foco no controle do processo e preservação das metas fiscais, as despesas programáticas não protegidas por vinculação constitucional/legal ou suportadas por um fundo específico, são sempre alvos de reduções ou congelamentos, em momentos de ajuste, nos quais a programação acurada parece ter pouca importância (Peres; Santos, 2018; p.114).

As reformas buscam a ampliação do volume dos recursos orçamentários livres e, em certa medida, contrapõe-se à crescente vinculação das receitas fiscais a gastos específicos, manifesta na Constituição, durante a década de 1990 e início dos anos 2000. As políticas públicas de saúde e educação garantem suas vinculações de receita, por exemplo. Ao passo que

\footnotetext{
132 Peres, 2018; pp.119-20.

133 Sobre esse parágrafo, ver Peres, 2018; pp.117-20; Peres; Santos, 2018; pp.112-4; Core, 2001; p.29.
} 
setores asseguram parcelas do orçamento a setoriais específicos via regulação orçamentária, também acirram a disputa entre os demais setoriais em torno do orçamento público. A disputa em torno do orçamento é ainda acirrada em acordo com a escassez dos recursos públicos e, assim como a economia, as dimensões processuais e políticas são necessárias à compreensão da destinação e execução dos recursos orçamentários. A associação entre gastos mínimos, despesas obrigatórias, ampliação do controle sobre as finanças e da inflação indicam a rigidez orçamentária brasileira, que permanece enquanto dimensão do novo regime fiscal brasileiro. O pagamento de salários, benefícios sociais e aposentadorias é obrigatório, por exemplo. ${ }^{134}$ Para citar o caso do município de São Paulo, as despesas incomprimíveis representam cerca de $80 \%$ das receitas líquidas dessa prefeitura. ${ }^{135}$ As políticas urbanas e habitacionais não garantem sua vinculação de receitas no orçamento público federal, entendidas assim enquanto gastos orçamentários discricionários (ou não obrigatórios), o que significa fortes implicações ao financiamento fiscal (financiamento não-oneroso) do desenvolvimento urbano frente aos ajustes da década de $1990 .{ }^{136}$

A partir da Constituição Cidadã são apresentadas a universalização de direitos e a descentralização do poder. ${ }^{137}$ Em específico sobre a política urbana, movimentos sociais de todo o país haviam formalizado uma proposta coletiva, estimulados pela possibilidade de submissão de emendas populares à Assembleia Nacional Constituinte. ${ }^{138}$ Por meio dos artigos 182 e 183, a Carta de 1988 apresentou a política urbana brasileira, e o artigo 183 constitucionalizou o usucapião. ${ }^{139}$ Em linhas gerais, a política urbana da Constituição de 1988 associou-se ao fortalecimento dos municípios, da participação popular e democratização dos

\footnotetext{
134 Sobre este parágrafo, verificar Peres, 2018; Santos, 2016; Schick, 1976; Lopreato, 2013; p.182-4;190; Santos, 2016; p.27-8 apresenta considerações sobre as despesas obrigatórias e vinculação de receita federal, por exemplo. 135 Peres, 2018; p.128.

136 IPEA, 2005.

137 Nos termos de Fiori (2004): projeto de desenvolvimento econômico nacional e popular.

138 Maricato, 1988.

139 “Art. 183. Aquele que possuir como sua área urbana de até duzentos e cinquenta metros quadrados, por cinco anos, ininterruptamente e sem oposição, utilizando-a para sua moradia ou de sua família, adquirir-lhe-á o domínio, desde que não seja proprietário de outro imóvel urbano ou rural".

Fonte: <http://www.planalto.gov.br/ccivil_03/constituicao/constituicao.htm>, consultado em agosto de 2019.
} 
processos decisórios. ${ }^{140} 141$ Contudo, a Constituição de 1988 não apresentou avanços à superação da crise da década de 1980, ou mesmo à inquietação a respeito da intervenção estatal na economia. ${ }^{142}$

A Constituição de 1988 espelha-se no regime fordista, à época já em crise até mesmo na Europa. ${ }^{143}$ É verdade que o artigo 239 da Constituição regula os recursos PIS-Pasep, ${ }^{144}$ ampliando a arrecadação e capacidade de gasto federal por exemplo, mas a resposta às inquietações fiscais da "década perdida" fica a cargo dos governos Collor, Itamar Franco e Fernando Henrique Cardoso, e em especial deste. Os governos democráticos da década de 1990 efetivam reformas estruturais e, associada a essas, uma nova inserção mundial da economia brasileira, agora em consonância à crise do regime fordista no mundo e orientada à valorização financeira com maior presença do capital privado internacional. ${ }^{145}$ Não somente o Brasil, mas a

\footnotetext{
${ }^{140}$ Maricato, 1994.

${ }^{141}$ Massonetto (2019; pp.276-8) avança sobre a relação entre a Carta de 1988 e o urbano. O autor apresenta que: "Existe um profundo entrelaçamento entre a regulação da atividade urbanística, a regulação da atividade econômica pelo Estado e a regulação da atividade financeira pelo Estado. A atividade urbanística é uma atividade econômica e está sujeita a todas as prescrições jurídicas atinentes à atuação estatal no domínio econômico. Incidem sobre as atividades urbanísticas todos os princípios gerais da atividade econômica previstos na Constituição, tais como a função social da propriedade, a livre concorrência, a defesa do meio ambiente, a redução das desigualdades regionais e sociais, dentre outros. [...], o que projeta toda regulação constitucional incidente sobre a atividade econômica e financeira para a regulação do espaço urbano. [...] A efetividade das normas urbanísticas depende, portanto, da aderência de seu conteúdo normativo às condições materiais de realização dos seus objetivos concretos, [...]." O autor segue com o desenvolvimento do argumento, e defende a importância da não compreensão sobre o urbano apenas a partir da esfera local estatal.

142 Lopreato, 2013; p.167.

${ }^{143}$ Agradecemos ao debate junto a Luís Fernando Massonetto e Luciana de Oliveira Royer.

144 "A principal fonte de recursos do FAT (Fundo de Amparo ao Trabalhador) é composta pelas contribuições para o Programa de Integração Social - PIS, criado por meio da Lei Complementar n 07, de 07 de setembro de 1970, e para o Programa de Formação do Patrimônio do Servidor Público - PASEP, instituído pela Lei Complementar no 08, de 03 de dezembro de 1970. A partir da promulgação da Constituição Federal, em 05 de outubro de 1988, nos termos do que determina o seu art. 239, os recursos provenientes da arrecadação das contribuições para o PIS e para o PASEP foram destinados ao custeio do Programa do Seguro Desemprego, do Abono Salarial e, pelo menos quarenta por cento, ao financiamento de Programas de Desenvolvimento Econômico, esses últimos a cargo do Banco Nacional de Desenvolvimento Econômico e Social [...]".

Fonte: $\quad$ http://portalfat.mte.gov.br/codefat/resolucoes-2/resolucoes-por-assunto/geracao-de-emprego-erenda/linhas-de-creditos-especiais/fat-giro-cooperativo-agropecuario/sobre-o-fat/>, consultado em agosto de 2019.

145 Paulani, 2009; p.34; Lopreato, 2013; p.197.

Estes processos são longos e conflituosos, inclusive em países onde houve a construção do Estado de Bem-Estar Social. Boyer (2012) discute o fortalecimento das políticas de austeridade fiscal em países europeus durante o ano de 2011. Boyer complexifica, então, os recorrentes cortes de gasto público, ampliação de tributos e redução das políticas sociais, por exemplo. Para o autor, a racionalidade por trás das recentes políticas de austeridade fiscal europeias recentes não podem ser entendidas sem atenção à crise norte-americana de 2008 (Boyer, 2012; p.285).
} 
América Latina verifica a passagem do Estado Provedor ao Estado Regulador durante a década de 1990, nos termos de Rezende (2006; pp.30-4). Os descompassos entre os campos políticosocial e econômico brasileiros durante a década de 1990 foram amplamente discutidos por literatura nacional, com atenção aos limites à universalização de direitos frente à dissolução de capacidade da atuação estatal sobre a oferta de bens e serviços e da intervenção sobre a demanda agregada, por exemplo. ${ }^{146}$ Mesmo na década de 1990, a construção de um ambiente institucional favorável ou de condições ao mercado já não parece ser, por si só, suficiente ao atendimento das necessidades urbanísticas e habitacionais dos mais pobres no Brasil.

De qualquer modo, durante a década de 1990 verificam-se marcos às políticas urbanas e habitacionais brasileiras, e em especial após o Plano Real. Royer (2009) e Cardoso; Aragão (2013) apoiam esse entendimento. Após a extinção do BNH em 1986, o FGTS é assumido pela Caixa Econômica Federal (CEF). Em 1990 há a retomada das operações dos recursos do FGTS, responsável por investimentos em habitação popular entre 1990 e 1991, mas com fortes críticas acerca da alocação e gestão dos recursos do fundo durante esse período. Com destaque à crise do fundo durante o governo Collor, e frente à sensibilidade do FGTS aos ciclos econômicos, em 1994 é instituído o seu Conselho Curador (CCFGTS). Em 1995 é criado o Programa Carta de Crédito, que visa a concessão de crédito à população alvo do FGTS, em torno da aquisição, construção, conclusão de materiais de construção, unidade habitacional ou lote urbanizado, possivelmente com maior aderência ao mercado de imóveis usados. O Programa Carta de Crédito foi a iniciativa mais expressiva da década de 1990, em termos de contratações de financiamento e ampliação do crédito imobiliário, mas ainda fragilizado frente às concomitantes altas taxas de juros no país. Até 1997, o Programa Pró-Moradia, também financiado com recursos FGTS, foi o principal apoio aos governos subnacionais. Ainda constam o Habitar Brasil e o Pró-Saneamento, respectivamente financiados pelo Orçamento Geral da União e FGTS, destinados ao setor público. ${ }^{147}$ Apesar de avanços em termos de desenho institucional, as

\footnotetext{
146 Maricato (1996; 1998); Vainer (2002); Martins (2003); Dagnino (2004); por exemplo. Arantes (2006) discute o ajuste das políticas urbanas paulistanas durante a década de 1990, com destaque à interface entre administração pública, Banco Mundial e Banco Interamericano de Desenvolvimento.

147 O Habitar Brasil foi criado durante o governo Itamar Franco, o Pró-Moradia e Pró-Saneamento durante o governo FHC. O Habitar Brasil permanece durante o governo FHC, e destaca-se enquanto o único programa
} 
articulações interfederativas são pouco expressivas durante o período, em especial devido ao estrutural contingenciamento de recursos, à baixa capacidade de pagamento do setor público e à baixa capacidade administrativa dos estados e municípios, ou até mesmo devido ao contingenciamento do crédito ao setor público pelo Banco Central em 1997. O Programa de Arrendamento Residencial (PAR) é proposto enquanto substituição ao Pró-Moradia, conta com recursos do FGTS e OGU, sistema de subsídios, e oferta de crédito às construtoras. Os empreendimentos financiados pelo PAR são entregues à CEF, com demanda cadastrada pelos municípios e avaliada pela CEF. O PAR é destinado à faixa salarial de 3 a 6 salários mínimos, com verificada concentração dos beneficiados em limite superior desse intervalo. Em 1997 é aprovado o Sistema Financeiro Imobiliário (SFI) e possibilitada a criação de companhias securitizadoras e a emissão dos Certificados de Recebíveis Imobiliários no país. O SFI iniciaria sua operação apenas durante a década de 2000, com significativa expansão a partir de $2005 .{ }^{148}$

\subsubsection{Resgate de mecanismos da atuação estatal ${ }^{149}$}

Após a crise cambial de 1999, apesar da mudança de grupo político dirigente a partir da eleição de presidente Luís Inácio Lula da Silva em 2002, a estratégia adotada é a continuidade do Programa de Ajuste Fiscal de 1998, assumindo a sustentabilidade da dívida pública enquanto epicentro da política econômica. A meta original do Plano Real, a eliminação do déficit público, é resgatada, por exemplo. Na época e por meio da FIRJAN e FIESP, setores industriais apoiam o corte do gasto público como meio à queda da taxa de juros e retomada de crescimento. $\mathrm{O}$ desempenho favorável do PIB em 2004 reforça os esforços governamentais de ajuste e elevação do superávit primário. Em 2003 o crescimento do PIB é de 1,1\%, em 2004 equivale a 5,8\%. O gasto via Orçamento Geral da União decresce 1,9\% em 2004, ao passo que o resultado primário do setor público em relação ao PIB cresce de 4,3\% para 4,6\% nesse mesmo período. A proposta de aprofundar o ajuste fiscal frente ao aumento de taxas de juros e desaceleração do

\footnotetext{
financiado com Orçamento Geral da União à época da Secretaria de Política Urbana do Ministério do Planejamento e Orçamento.

148 Sobre este parágrafo verificar Royer, 2009; pp.67-70;85-6; Cardoso; Aragão, 2013; p.20-26. Desse modo, não é possível afirmar que a década de 2000 significa o retorno de esfera federal às políticas urbanas e habitacionais. Evidente, há espaço para a discussão sobre permanências e continuidades.

149 Termos em acordo com Lopreato, 2013.
} 
crescimento encontra resistência no âmbito do governo federal em 2005. O crescimento do PIB equivale a $3,2 \%$ em $2005 .{ }^{150}$

Busca-se, então, conciliar a revisão de estratégia de política fiscal ao controle fiscal entre 2005 e 2006. Sem rupturas, a nova estratégia preocupa-se em remontar mecanismos estatais com vistas a impulsionar o crescimento nacional. A articulação entre apoio ao capital privado, empresas estatais, projetos de infraestrutura, políticas sociais e de transferência de renda, aumento real do salário mínimo e dos gastos previdenciários, expansão do crédito via bancos públicos para a agricultura, construção civil, pequenas e médias empresas e também consumo, subsídios fiscais e taxas de juros privilegiadas, política industrial e de internacionalização de empresas privadas, por exemplo, ganha fôlego. Essa estratégia fiscal já ganha força antes de 2008, mas o risco da afetação nacional frente à crise internacional contribui à validação temporária das iniciativas de governo federal. ${ }^{151}$

Segundo Lopreato (2013; pp.216-9), o regime fiscal estruturado durante o período FHC não sofre alterações centrais nos anos 2000, inclusive no que se refere às implicações sobre o federalismo brasileiro. Em associação a isso, desde 2005 o regime fiscal admite a possibilidade de excluir as despesas com o Projeto Piloto de Investimentos (PPI), substituído pelo Programa de Aceleração do Crescimento (PAC) em 2007, da base do cálculo do resultado primário. Essa concepção segue recomendações de instituições multilaterais, referindo-se a uma carteira específica de projetos. Contudo, devido aos concomitantes esforços de redução da meta fiscal

150 Lopreato, 2013; pp.205-11. Dados: Sistema Integrado de Planejamento e Orçamento - Ministério do Planejamento, Desenvolvimento e Gestão do Governo Federal; Banco Central do Brasil; Instituto Brasileiro de Geografia e Estatística.

${ }^{151}$ Lopreato, 2013; pp.211-6; 219; Bastos, 2017; p.80.

Segundo Bastos (2017; p.80), o salário mínimo cresce 70\% entre 2004 e 2014. Para Paulani (2017; p.93) esse cresce $85 \%$ entre 2003 e 2014. Ou seja, nem todos os mecanismos enumerados acima remontam específica ou exclusivamente ao ano de 2006.

Lopreato (2013; pp.233-7) enumera medidas institucionais e econômicas com vistas ao fortalecimento dos bancos públicos, e também a exposição de argumentos contrários a essas manobras. Apresenta-se crítica ao rompimento da "tradição de independência financeira" do BNDES frente ao Tesouro (p.236).

Nassif (2019; pp. 14-5) é convergente à avaliação sobre a guinada de estratégia fiscal em 2006. Para Nassif, a origem do PAC está relacionada ao embate entre a então ministra da Casa Civil, Dilma Rousseff, frente à proposta de ajuste fiscal de longo prazo, apresentada por Antônio Pallocci e Paulo Bernardo, ministros da Fazenda e do Planejamento, respectivamente. Desse modo, o PAC é concebido enquanto estratégia de alavancamento do investimento agregado e fortalecimento do crescimento econômico nacional. 
e ampliação da receita, a dedução dos investimentos e despesas PAC de resultado primário federal apenas ocorreu em 2009 e 2010. ${ }^{152}$ A Medida Provisória 496, de 19 de julho de 2010, autoriza as cidades-sede da copa do mundo de 2014 a tomar crédito para o financiamento de obras. A Medida Provisória 487, de 23 de abril de 2010, dispensa estados com crescimento econômico abaixo de $1 \%$ de cumprir as regras de superávit primário previstas em lei, viabilizando a expansão dos gastos e investimentos públicos, assim como o recebimento de transferências federais e a contratação de empréstimos. ${ }^{153}$

Entre 2006 e 2010 o Brasil apresenta importante crescimento econômico, com um crescimento do PIB real de 7,5\% em 2010, de acordo com o IBGE. Entre 2004 e 2008 o comércio mundial cresce 15\% ao ano, e as exportações brasileiras, mesmo em 2003, refletem a expansão de exportações industriais para a América do Sul e de commodities para a China. A cooperação sul-sul é expressão da diplomacia no período. ${ }^{154}$ Dentre outros, o recente período de crescimento econômico associa-se à ampliação dos investimentos públicos e consumo interno. ${ }^{155} \mathrm{Em} 2006$ o investimento público federal corresponde a 0,6\% do PIB, em 2010 esse índice equivale a 1,2\%, segundo a Secretaria do Tesouro Nacional do governo federal e desconsideradas as estatais.

O desempenho da economia, incluídas a desaceleração e subsequente recessão econômica a partir de 2011 e 2015, respectivamente, também se relaciona com a política fiscal e o cumprimento das regras fiscais. ${ }^{156}$ A redução do desemprego é mantida até 2014, mas as causas desse fenômeno estão em debate. ${ }^{157} \mathrm{~A}$ abrangência de políticas sociais experimentadas durante o período encontra-se em avaliação, com relevantes explicações sobre seus impactos sobre as desigualdades. ${ }^{158}$ Estudos identificam tensões em torno do fortalecimento de atuação estatal frente à condução e articulação de investimentos, sendo essas tensões evidências de

\footnotetext{
152 Carvalho, 2018; pp.31-2.

153 Lopreato, 2013; p.221.

154 Bastos, 2017; p.79.

155 Carvalho, 2018; Nassif, 2019.

156 Dweck; Teixeira, 2017; Barros, 2017; pp.81-2.

157 Saboia, 2014; Dweck; Teixeira, 2017.

158 Soares, 2006; 2010; Barros; Henriques; Mendonça, 2010; Arretche, 2015; 2018; Souza, 2018.
} 
contexto democrático, ainda que a participação social e a operacionalização desses processos pelas instituições brasileiras tenha revelado desafios. ${ }^{159}$

Certamente os governos de Luís Inácio Lula da Silva demandam avaliações complexificadas, tarefa dificultosa na ausência de distanciamento histórico. ${ }^{160}$ Contudo, parece existir consenso a respeito da construção e sofisticação de institucionalidades frente às políticas urbanas e habitacionais durante a década de 2000, em especial durante os governos Lula, e em contraste à trajetória errática dessas políticas durante a década de $1990 .^{161}$

1.2.4 Políticas urbanas e habitacionais federais e o cenário de austeridade fiscal permanente

O declínio do regime militar marca o início da constitucionalização permanente no Brasil, ${ }^{162}$ e a constitucionalização da moradia enquanto direito social acontece no ano de 2000. A afirmação da moradia enquanto direito social efetiva a responsabilização do Estado brasileiro frente à universalização do acesso à casa. ${ }^{163}$ Em 2001 é aprovada a Lei Federal № 10.257, o Estatuto da Cidade, regulamentação dos artigos 182 e 183 da Constituição Federal. Em linhas

159 Maricato, 2007; Gomide; Pires, 2013.

160 Ver entrevista concedida por Maria da Conceição Tavares ao Globo News em 2009, disponível em: <https://www.youtube.com/watch?v=K_qunKjZf4U>, link consultado em agosto de 2019. Em entrevista, Tavares debate as virtudes de governos Lula, dentre essas o seu caráter popular, a política externa fortalecida e a retomada de atuação estatal frente à condução de economia nacional, por exemplo.

Sobre o caráter popular do governo Lula, destaco o empréstimo de 200 milhões de reais contratado por cooperativa de catadores de papel junto ao BNDES. Informação extraída de entrevista concedida pelo presidente Luís Inácio à Rede Record em 21 de julho de 2010, disponível em: <https://www.youtube.com/watch?v=MXTWnpSNL_M>, link consultado em agosto de 2019. Além disso, são garantidos direitos trabalhistas de empregadas domésticas e ampliado o acesso de população de baixa renda ao ensino superior via ProUni ou ampliação de rede de institutos federais, por exemplo.

Francisco de Oliveira (2018 [2005; 2006; 2007; 2009]) apresenta críticas aos governos Lula, sendo as críticas especialmente orientadas às políticas "antissociais e antitrabalhador" (2018 [2006]; p.67). Durante participações no programa Roda Viva da TV Cultura, televisionadas em 10 de dezembro de 2003 e 30 de dezembro de 2013, Oliveira debate a "funcionalização da pobreza" por governos Lula. A crítica de Oliveira remonta à não permanência de medidas efetivadas pelo governo, por exemplo. Quais instituições foram construídas? Entrevistas disponíveis em: $\quad<$ https://www.youtube.com/watch?v=TFzPvVPLuqA>; $\quad<$ https://www.youtube.com/watch?v=fF-hGyhrO$8 \& \mathrm{t}=3988 \mathrm{~s}>$, links consultados em agosto de 2019.

${ }^{161}$ Arretche, 1996 apud Royer, 2009; p.95; Maricato, 2006; p.214.

162 Arantes et al., 2019.

163 É necessário reconhecer a premissa de universalização de direitos que permeia a Constituição Cidadã, e o rompimento da lógica de acesso a direitos a partir da situação trabalhista em 1988. Mesmo que relevante a garantia da moradia enquanto direito social, parecem faltar evidências sobre o impacto da Emenda Constitucional № 26 na condução das políticas no país. Agradecemos aos comentários de Luciana de Oliveira Royer e Luís Fernando Massonetto. 
gerais, o Estatuto trata de regulamentar a função social da propriedade, instituindo diretrizes e instrumentos de viés democrático. Cabe enumerar a Lei Federal da Parceria Público-Privada № 11.079 em 2004; Lei Federal do Consórcio Público № 11.107 em 2005; Lei Federal do Fundo Nacional de Habitação Social (FNHIS) № 11.124 em 2005;164 Lei Federal do Saneamento Básico №11.445 em 2007; Lei Federal dos Resíduos Sólidos № 12.305 em 2010. O Ministério das Cidades é criado em 2003, composto pelas secretarias da Habitação, Saneamento, Mobilidade Urbana e Programas Urbanos, e sua criação é acompanhada pela consolidação de corpo técnico concursado e a construção de capacidade administrativa e de planejamento das políticas urbanas e habitacionais federais. O Conselho Nacional das Cidades é criado em 2004, e as Conferências Nacional das Cidades são realizadas em 2003, 2004, 2005, 2007, 2010, 2013 e 2016. É implementado o programa Luz para Todos. O Programa de Aceleração do Crescimento (PAC) é inaugurado em 2007, e o Programa Minha Casa, Minha Vida (PMCMV) é anunciado em 2009. Em 2008 é apresentado o Plano Nacional de Habitação (PlanHab) federal. ${ }^{165}$ É sancionada a Lei Federal da Mobilidade Urbana № 12.587 em 2012 e o Estatuto da Metrópole, Lei Federal № 13.089 em 2015.

Segundo Bonduki (2014; pp.108-9), as políticas implementadas durante os governos Lula resultam do amadurecimento de propostas desenvolvidas após o fim do BNH, e até mesmo incorporam propostas do Seminário de Habitação e Reforma Urbana realizado em 1963. Ainda segundo Bonduki, a política nacional de habitação dos governos Lula remete também ao Projeto Moradia, documento lançado em 2000, que parte da preocupação sobre a articulação entre o

\footnotetext{
${ }^{164}$ A lei que cria o FNHIS também cria o Sistema Nacional de Habitação de Interesse Social e estabelece regras para a articulação entre os entes federados. Para acessar os recursos do FNHIS, estados e municípios precisam de fundo, plano e conselho setorial específico (Bonduki, 2014; p.111).

Segundo Arretche (2019; por volta do minuto 65), a construção institucional do SNHIS representa estratégia de emulação de sistemas de políticas já consolidados, a exemplo do SUS. Neste sentido, e segundo Arretche, verificase o adensamento e ampliação de cobertura por políticas públicas, mas não é verificada ruptura paradigmática em termos de construção institucional, políticas públicas e políticas sociais durante o início do século XXI. Verificar apresentação de Arretche em ocasião da comemoração dos 50 anos do CEBRAP. Apresentação de Arretche disponível em: <https://www.youtube.com/watch?v=wLz-_nXmh_E>, link consultado em agosto de 2019.

165 Para avaliações sobre o PMCMV consultar Santo Amore; Shimbo; Rufino (2015), por exemplo. Sobre o PACUrbanização de Assentamentos Precários consultar Cardoso; Denaldi (2018), por exemplo. Sobre o Conselho e Conferências das Cidades consultar Rodrigues (2011), por exemplo. Sobre o PlanHab consultar Cardoso; Aragão (2013); Bonduki (2014), por exemplo. Sobre a política de desenvolvimento urbano e o Ministério das Cidades consultar Maricato (2006); Maricato; Royer (2017), por exemplo.
} 
problema da moradia, crescimento econômico e geração de empregos. Maricato (2006; p.215) sintetiza: "O Ministério das Cidades tem sua criação, portanto, ligada a esse movimento social urbano que teve início ainda nos anos 1970 e que acumulou forças nas duas décadas seguintes na luta pela democratização do país e pela reforma urbana".

O financiamento habitacional expande-se em ritmo acelerado durante a década de 2000, ultrapassando em termos quantitativos o desempenho do período militar e extinto BNH. Superada a crise cambial de 1999, e com as taxas de juros mais baixas, há o aumento de investimentos e concessão de crédito. Segundo Royer (2009), a partir de 2003 o SFH incorpora mudanças que qualificam seu desempenho, e entre 2003 e 2008 há um aumento de aproximadamente $345 \%$ no número de financiamentos para aquisição de imóveis destinados a pessoas físicas sob as condições do SFH, mesmo após recrudescimento verificado para este indicador entre 1995 e 2002; e um aumento de aproximadamente 895\% no financiamento da construção de novas unidades, expressão de um boom imobiliário antes mesmo do PMCMV. Esses números correspondem aos financiamentos contratados via SBPE, as cadernetas de poupança brasileiras, e remontam à melhoria de ambiente regulatório, melhoria do crédito para a pessoa física com mudança da taxa de juros, prazos e valor de entrada, além da estabilidade macroeconômica (Royer, 2009; pp.71-80). As contratações de financiamento com recursos SBPE continuam sua expansão até 2014, seja em termos de valores financeiros ou número de unidades habitacionais financiadas. Em 2003, 34.601 unidades habitacionais são financiadas com recursos do SBPE, em 2014 o índice é de 538.236 (Maricato; Royer, 2017; p.155).

Relativo ao FGTS, a criação e fortalecimento do Ministério das Cidades influenciam a composição e forma do CCFGTS. O MCidades é responsabilizado pela gestão dos recursos do FGTS, e estabelece metas aos programas de habitação popular, saneamento básico e infraestrutura urbana. A partir de 2003, o CCFGTS e CEF aprimoram programas, processos e procedimentos, significando a melhoria da avaliação de risco de crédito para pessoas físicas e jurídicas, por exemplo. Em 2003 o contingenciamento de crédito ao setor público é excepcionado a aplicações específicas do FGTS. A Resolução CCFGTS № 460 de 2004 garante $60 \%$ dos recursos de aplicação do fundo para habitação popular, 30\% para saneamento básico, 5\% para infraestrutura urbana, $5 \%$ operações especiais. Esses percentuais são alterados ao 
longo do tempo. A partir de 2005, a Resolução CCFGTS № 460 ainda implementa subsídio destinado à pessoa física contratante de financiamento com recursos do FGTS e renda familiar bruta de até $R \$ 1.500,00$ (valor referência de 2004), ampliando a capacidade de atendimento da população de baixa renda pelo fundo. O orçamento final do FGTS em 2008 é 8,5 vezes superior ao orçamento de 1995, o que indica a disponibilidade financeira e política frente à gestão dos recursos do fundo, ainda que os diferentes programas financiados pelo FGTS apresentem desempenhos díspares. Em comparação ao desempenho apresentado pelo SBPE, é clara a maior tendência de afetação das demandas urbanas e habitacionais da mais baixa renda possibilitada via FGTS (Royer, 2009; pp.87-93). O modelo de subsídio implementado pela Resolução № 460 é adotado pelo PMCMV. As contratações com recursos do FGTS partem de 246.107 unidades habitacionais em 2003, atingem o pico de 528.093 unidades em 2010, e em 2015 representam o financiamento de 478.767 unidades (Maricato; Royer, 2017; pp.153-4).

Para além de avaliações sobre o FGTS e SBPE (recursos onerosos), a literatura ressalta a importância de melhor compreender o desenvolvimento urbano a partir do Orçamento Geral da União (Royer, 2009; pp.46-7), também devido ao aporte inovador de recursos não-onerosos às políticas urbanas e habitacionais durante os governos Lula e Dilma (Maricato; Royer, 2017; p.153).

Os governos Lula e Dilma realizam importantes gastos sociais no país, e o fortalecimento de atuação estatal é consenso no que se refere ao financiamento do desenvolvimento urbano. Em 2010 o total dos investimentos públicos federais equivalem a 1,2\% do PIB real brasileiro, desconsideradas as estatais e de acordo com a Secretaria do Tesouro Nacional. Contudo, o período de 2003 a 2016 apresenta matizes.

Em 2011 há ajuste nos investimentos federais, e entre 2012 e 2013 há uma disputa pública em torno das taxas de juros. Esse período aponta as bases de uma nova crise brasileira. 2014 é marcado por um crescimento do PIB real de 0,5\% e pelo déficit fiscal de 0,6\% em relação ao PIB. O PIB real decresce a partir de 2015, e o déficit fiscal amplia-se para 2\% em 2015, e 2,5\% em 2016, segundo o IBGE e o Banco Central do Brasil. A meta fiscal federal em 2014 é de 1,2\%, sobe para $1,83 \%$ em 2015, e sobe outro 0,7\% em 2016. A crise internacional de 2008, a queda 
dos preços das commodities e a Operação Lava-Jato vinculam-se ao debate. ${ }^{166}$ Ou seja, frente à desaceleração e recessão econômica nacional iniciadas em 2011, frente à decorrente queda de arrecadação fiscal, o gasto federal é questionado, com implicações sobre os serviços, políticas e investimentos estatais.

Como decorrência de um processo, incluídos neste o impedimento da presidente Dilma Rousseff e mandato de Michel Temer, é sancionada a Emenda Constitucional 95 em 2016, congelando por 20 anos as despesas correntes do governo federal, com a exceção dos juros. Segundo especialistas, a EC 95/2016 é um "choque" no orçamento público, e os impactos da austeridade fiscal permanente sobre as políticas sociais são imediatos. ${ }^{167}$

É impertinente, contudo, imaginar que a severidade da economia sobre os serviços, políticas e investimentos estatais é uma característica brasileira, ${ }^{168}$ apesar das feições que essa severidade adquire na periferia do sistema mundo, ${ }^{169}$ em nosso país e frente ao problema

\footnotetext{
166 Bastos, 2017; pp.82-3; Singer, 2015.
}

${ }^{167}$ Brasil Debate e a Fundação Friedrich Ebert lançam, em 2018, avaliação dos impactos da austeridade fiscal sobre as políticas sociais brasileiras. Documento disponível em: <http://brasildebate.com.br/wp-content/uploads/DOCAUSTERIDADE_doc3-_L9.pdf>, link consultado em agosto de 2019.

Segundo Fagnani (2017; pp.128-9), há alguns principais marcos ao recente movimento de desestruturação da cidadania social no Brasil: a EC95/2016, a Reforma da Previdência e a desregulamentação de relações trabalhistas são alguns deles.

Entre 2003 e 2015 o pagamento de juros pela União significa uma média de 4,5\% do PIB de cada ano. Para Kliass (2017; pp.102-3) esse fato relaciona-se ao "rigor na extração do superávit primário" durante os governos Lula e Dilma. Frente à desaceleração e recessão econômicas, isso aponta a contenção de gastos públicos não financeiros com vistas ao pagamento de juros da dívida pública. Segundo Kliass, entre 2003 e 2015 R\$3,1 trilhões do Orçamento Geral da União foram destinados ao pagamento de despesas financeiras associadas aos juros da dívida pública.

Para Fevereiro (2017; p.107) o debate sobre a dívida pública deve ser complexificado, com vistas a superar a dicotomia "orçamento equilibrado" e "impactos sobre os gastos primários da União". O crescimento da dívida pública relaciona-se com o custo de sua remuneração e, desse modo, tanto o crescimento econômico quanto a revisão de taxa Selic são relevantes ao entendimento do déficit nominal brasileiro. O autor entende que a dívida pública pode contribuir ao desenvolvimento nacional, desde que não remunerada a taxas expressivamente altas. 168 Boyer, 2012; Schäfer; Wolfgang, 2013; Streeck, 2014; Pierson, 2001.

169 Inclusive em termos teóricos, e consideradas as transformações de/atual estágio do padrão de acumulação capitalista, De Paula et al. (2017) defendem que economias em condição periférica estão sujeitas a maiores constrangimentos à adoção de políticas de orientação keynesiana, manutenção de pleno emprego ou estabilidade macroeconômica, por exemplo. Os constrangimentos associam-se, por exemplo, à maior vulnerabilidade de economias periféricas a choques externos. Sobre isso, e em comparação às economias centrais, a volatilidade dos fluxos de capitais é maior nas economias periféricas, por exemplo. "[...] at points of reversal of the cycle, of monetary policy changes in the center or of increase in the liquidity preference, emerging financial assets are the first victims of the global investors 'flight to quality', as they cannot provide a safe heaven under uncertainty on a global scale. [...] Within the global currency hierarchy, the currencies of peripheral emerging economies are characterized by a lower liquidity premium than the currencies of center economies, which is severely damaging 
urbano brasileiro. O início do século XXI matiza a tendência presente desde a década de 1990 no Brasil, expressa pela construção e manutenção de determinado regime fiscal e inserção internacional de economia brasileira, já debatidos anteriormente. Não é possível, contudo, igualar o início do século XXI à experiência estatal do século XX. ${ }^{170}$ Por complicada que seja a ideia de reversão dos processos sociais, é a partir de uma perspectiva social, histórica e econômica nacional e brasileira que Tavares (2019 [2017]) argumenta: "Restaurar o Estado é preciso".

\subsection{Desenvolvimento urbano enquanto fenômeno social e econômico}

Historicamente, verificam-se arranjos do Estado frente ao urbano e ao problema urbano, expressão de processos sociais. Mas a atuação estatal frente ao desenvolvimento urbano permanece pertinente à sociedade e às cidades brasileiras? Neste sentido, é adiante debatida a relevância social e econômica de atuação estatal frente ao desenvolvimento urbano no país. Em um primeiro momento, identificam-se os termos sociais dessa relevância, e em um segundo momento seus aspectos econômicos.

1.3.1 Relevância social de atuação estatal frente ao desenvolvimento urbano

Os dados apresentados por Souza (2018; p.41) impressionam: A apropriação da renda pelo 1\% mais rico no Brasil é marcada por relativa estabilidade histórica, mas também por sua magnitude, permanecendo quase sempre superior ao índice de 20\% entre 1926 e 2015, alcançando esporadicamente a marca dos 30\% da renda no país. Apesar de observações necessárias a respeito dos dados apresentados por Souza (2018), ${ }^{171}$ em comparação aos seis países avaliados por autor, centrais ou periféricos, não se verifica paralelo histórico ao desempenho brasileiro. Mais recentemente, a partir das décadas de 1980 e 1990, há expressiva

\footnotetext{
for a sustained growth process" (De Paula et al., 2017; p.191; 199). Prates et al. (2017) particularizam o argumento para o caso brasileiro, e argumentam que, em termos de vulnerabilidade externa entre 2003 e 2016, os resultados para a economia nacional são mistos (p.200).

170 Paulani (2017; pp.93-4) apresenta dados sobre os investimentos públicos durante o regime militar, e estabelece a comparação desses com o período recente de nossa história. Mesmo considerado o PAC, o montante de investimentos do governo central em relação ao PIB durante o período Lula chega a ser 3 ou 4 vezes menor do que aquele verificado entre 1950 e 1980 (Paulani, 2017; p.98).

171 Os ganhos de capital são incluídos para os cálculos do Brasil, Estados Unidos da América, Suécia, mas não para os cálculos da França, Argentina, Colômbia e África do Sul, por exemplo. Tendencialmente, os ganhos de capital representam ampliação da concentração de renda pelos mais ricos.
} 
ampliação da concentração da renda nos Estados Unidos da América, Argentina e África do Sul. A concentração da renda nesses países equipare-se, atualmente, aos patamares brasileiros.

O debate sobre a apropriação e distribuição da riqueza ganha um novo fôlego durante o início do século XXI, inclusive em termos de comparação internacional. ${ }^{172}$ Os trabalhos apresentam diferentes insumos, métodos, horizontes normativos, recortes e preocupações, cada qual com contribuição e inserção histórica própria, e que não necessariamente podem ser comparados entre si. De qualquer modo, sem prejuízo e como subsídio ao argumento aqui construído, destacam-se alguns estudos sobre o caso brasileiro.

Para Barros et al. (2000), o Brasil do início do século XXI não é um país pobre, mas notoriamente desigual e de marcada pobreza. "Desigualdade (econômica) que atravessou impassível o regime militar, governos democraticamente eleitos e incontáveis laboratórios de política econômica, além de diversas crises políticas, econômicas e internacionais" (Barros et al.2000; p.141).

Soares (2010) reforça a importância do mercado de trabalho para a compreensão da renda domiciliar per capita, assim como debate a complexidade desse fenômeno. Segundo o autor, as explicações desse fenômeno passam pela avaliação de políticas sociais, demografia e perfil educacional, por exemplo. O autor apresenta incertezas em torno da redução da concentração de riqueza no país durante a década de 2000. Interessa ainda destacar a seguinte afirmação de Soares (2010; p.376, grifo nosso):

Um país que se parece com o Canadá de hoje em termos de desigualdade não pode se parecer em nada com o Brasil que contemplamos da janela. Se continuarmos reduzindo nosso coeficiente de Gini a 0,7 ponto ao ano pelos próximos 24 anos, não será possível ter grandes favelas coexistindo com condomínios de luxo, indivíduos à beira da fome no sertão do Cariri vivendo no mesmo país cujos céus são cruzados por executivos viajando na segunda maior frota de aviões particulares do mundo, nem um exército de empregados particulares passando as roupas, encerando os pisos e lavando os banheiros da classe média.

Atualmente, segundo o Instituto de Pesquisa Econômica Aplicada, mais de 37 milhões de domicílios no Brasil possuem renda muito baixa. Ou seja, mais da metade dos domicílios no

\footnotetext{
${ }^{172}$ A exemplo da contribuição de Piketty (2014) são racionalizadas evidências acerca da renda de capital versus renda do trabalho, analisadas à luz dos regimes de poder em diferentes países, por exemplo. Piketty chega mesmo a questionar a centralidade dos regimes democráticos para a dissolução da desigualdade, por exemplo.
} 
país possui renda de até $\mathrm{R} \$ 1601,18$ em 2019. Em contrapartida, o número de domicílios de renda alta é ampliado no país. Com isso, a Pesquisa Nacional por Amostra de Domicílio (PNADIBGE) parece sugerir uma ampliação recente da desigualdade de renda do trabalho no Brasil. ${ }^{173}$

Para Arretche (2018), a distribuição da riqueza é melhor compreendida a partir de seu caráter multifacetado, sendo aquela afetada por processos políticos, mediados por políticas públicas; processos sociais, a exemplo da participação das mulheres no mercado de trabalho; processos econômicos, a exemplo do desempenho econômico nacional. Para a autora, os estudos sobre a desigualdade econômica deveriam contemplar a renda e também o acesso a serviços. ${ }^{174}$ Em termos gerais e segundo Arretche, se considerados os "99\% mais pobres" (excluído o 1\% mais rico) no Brasil, é possível argumentar a redução da desigualdade econômica entre 1985 e 2015. Essa redução seria explicada pela vinculação das pensões contributivas e não-contributivas ao valor do salário mínimo; universalização do acesso à educação e à saúde garantida pela Constituição de $1988 ;{ }^{175}$ convergência política à expansão do atendimento da população de mais baixa-renda, por exemplo.

Arretche (2015) avança no debate sobre o acesso a serviços no país. Verifica-se correlação entre riqueza, renda e acesso a serviços urbanos básicos, a exemplo de abastecimento de água, esgotamento sanitário, energia elétrica e coleta de lixo. Quanto maior é a renda domiciliar e a riqueza de determinado ente federativo, maior é a probabilidade de acesso aos serviços urbanos básicos, diagnóstico de relevo ao estudo do problema urbano no país. Neste sentido, a autora evidencia matizes territoriais do problema urbano.

173 <https://www.valor.com.br/brasil/6170641/mais-de-37-milhoes-de-lares-do-brasil-tem-renda-muito-baixanota-ipea>, consultado em setembro de 2019.

174 Parte da literatura apresentará o acesso aos serviços públicos e gratuitos como "renda indireta", "salário indireto" ou "salário político", a depender da orientação teórica. Por agora, mantemos os termos utilizados por autores referenciados.

Compatível ao debate apresentado por Esping-Andersen (1985), Levi (2016) debate a articulação entre as formas de financiamento, de provisão e de acesso às políticas e serviços de saúde, com atenção à promoção de justiça social a partir da atuação estatal. Ou seja, para além do quanto, importa como gastamos. Ambos autores indicam a relevância do debate sobre o gasto público.

175 O acesso universal à saúde e à educação pública são importantes conquistas sociais, e a Constituição Cidadã de 1988 é relevante marco deste debate. Hoje a renda não determina o acesso à saúde e educação básica no país. De qualquer modo, permanece necessário alinhamento entre universalização e qualidade. 
Arretche (2015) ainda caracteriza a trajetória do problema urbano no país. A universalização do acesso aos serviços urbanos básicos não é uma realidade brasileira. Com atenção aos mais pobres: (i) Em 1980, praticamente todos os domicílios dentre os 10\% mais pobres não possuem qualquer acesso aos serviços de esgoto; em 2015 este índice supera os 25\%; (ii) Em 1980, cerca de 10\% dos domicílios 10\% mais pobres possuem acesso aos serviços de abastecimento de água; em 2015 este índice aproxima-se aos 60\%; (iii) Em 1980, cerca de 10\% dos domicílios dos $10 \%$ mais pobres possuem acesso aos serviços coleta de lixo, hoje este índice aproxima-se dos 60\%; (iv) Em 1980, um pouco mais de 25\% dos 10\% mais pobres possuem acesso à energia elétrica, o acesso a este serviço é hoje virtualmente universal. Apesar da não universalização, verifica-se que a ampliação do acesso a essas infraestruturas e serviços urbanos dá-se de modo incremental no país, e destaca-se a ampliação do acesso a infraestruturas e serviços pelos mais pobres no Brasil. Segundo a autora, o atendimento das necessidades dos mais pobres é consequência da atuação estatal (Arretche, 2015; p.7; 427). Vale mencionar, nem sempre os $10 \%$ mais ricos dispuseram do acesso universal aos serviços urbanos básicos, também beneficiados por atuação estatal.

Segundo a Fundação João Pinheiro, em 2012 o déficit habitacional supera a marca dos 5 milhões de unidades habitacionais. A maior parte desses 5 milhões refere-se à habitação precária, gasto excessivo com aluguel e coabitação familiar. Segundo a Associação Nacional de Transportes Públicos (ANTP), entre 2003 e 2013 o custo individual do transporte coletivo subiu de cerca de 15 bilhões de reais para cerca de 40 bilhões de reais por ano no país. ${ }^{176}$

Politicamente, houveram conquistas que amenizaram as precariedades em nossas cidades, território e sociedade. Contudo, apesar dos avanços em termos de condições habitacionais e urbanas no país, permanecem as precariedades características de nossas cidades, especialmente no que se refere à situação experimentada pelos mais pobres (Marques, 2015; pp.233-4), mesmo em jurisdições ricas, como é o caso do município de São Paulo (Marques, 2014), ou das grandes metrópoles brasileiras (Pasternak; D’Ottaviano, 2016).

176 Dados extraídos de Faustino; Proni (2016). 
As disparidades sociais e espaciais brasileiras são evidências dos processos de produção e distribuição da riqueza no país. A produção e distribuição de riqueza, incorporadas aqui a distribuição de renda e o acesso aos serviços urbanos básicos, configura-se de modo distinto nos diferentes centros urbanos do país.

A renda é dimensão de compreensão do problema urbano, e o acesso à infraestrutura e serviços urbanos representa uma redistribuição indireta de renda, salário indireto, ou salário político. ${ }^{177}$ Contudo, por importante que seja a redistribuição de renda no país, uma forte política de aumento do salário mínimo parece ter alcance limitado à resolução do problema urbano. O combate ao problema urbano relaciona-se com a ampliação do sistema de serviços e infraestruturas urbanas e habitacionais. ${ }^{178}$

O enfrentamento do problema urbano é relevante socialmente, em especial se considerarmos o não-acesso a infraestruturas e serviços urbanos pelos mais pobres, e com destaque à demanda por ampliação do acesso a infraestrutura e serviços urbanos no país. ${ }^{179}$ Debater o enfrentamento do problema urbano passa, desse modo, por debater o financiamento dessas infraestruturas urbanas e habitacionais, do desenvolvimento urbano como um todo. É

177 Ver Comarú, 2004, por exemplo.

Sobre isso, mesmo que produto de relações sociais capitalistas, a atuação estatal guarda em si a potência nãomercantil em torno da casa e da cidade (cf. Jaramillo, 1982; cf. Esping-Andersen, 1985).

178 Ver Maricato, 2011, por exemplo.

Sobre isso, é central considerarmos a economia política da urbanização, a própria valorização imobiliária associada aos investimentos em infraestrutura urbana. Contudo, argumentamos que a dualidade em torno do desenvolvimento urbano pode ser dissolvida (não eliminada) diante do acesso universal à infraestrutura e serviços urbanos, estando o acesso à infraestrutura e serviços urbanos não relacionado à estrutura social de distribuição de riqueza no país, por exemplo. Ver Esping-Andersen, 1985; Arretche, 2015; p.428, por exemplo. Há defesas a respeito do fortalecimento de regulação e controle do mercado fundiário enquanto estratégia social.

179 É importante esclarecer que as dinâmicas do mercado imobiliário demandam atenção extra. A ampliação do crédito e aquecimento da produção imobiliária nos centros urbanos pode significar o acirramento de processos de segregação socioespacial, com fortes implicações à qualidade de vida dos mais pobres nas cidades brasileiras. Pensar o problema a ser enfrentado pela política habitacional é mais complexo do que a lei "oferta-procura", ou o atendimento da "meta do déficit habitacional". Parte da elaboração teórica passa pelo entendimento da terra enquanto um bem limitado, não produzido pelo trabalho, mas mercantilizado. Ver, por exemplo, Rufino (2016); Rufino; Pereira (2011). Há defesas a respeito do fortalecimento de regulação e controle do mercado imobiliário enquanto estratégia social. Entender o acesso dos mais pobres ao mercado imobiliário é também central ao debate, ponto tratado mais adiante. Além disso, é central a complexificação de atuação estatal, com atenção ao conceito de "necessidades habitacionais", e não à simples construção de novas unidades habitacionais. A respeito disso ver, por exemplo, o Plano Nacional de Habitação - PlanHab (Brasil, 2009), o qual avalia o "problema da habitação" no Brasil. 
neste sentido que parte da literatura aponta o caráter estratégico da atuação estatal para as cidades brasileiras. ${ }^{180}$

1.3.2 Relevância econômica de atuação estatal frente ao desenvolvimento urbano

A ideia de desenvolvimento econômico é controversa. O debate sobre o desenvolvimento econômico dedica atenção ao autoritarismo ou à super exploração do trabalho, este característico da modernização conservadora experimentada pelo país. As engrenagens e processos que articulam as históricas desigualdades e pobreza brasileiras, os estatutos trabalho e propriedade, e a concentração da apropriação privada de riqueza demandam argumentações robustas e, certamente, contribuem ao desvelamento de associações superficiais. ${ }^{181}$ A questão é complexa pois, mesmo em movimento de desindustrialização nacional e diante de profundas transformações globais econômicas e sociais, a concentração da riqueza pelos mais ricos permanece relativamente estável no Brasil, por exemplo.

Sem ignorar as preocupações necessárias ao debate sobre a economia e sociedade brasileiras, com atenção à ideia de um desenvolvimento nacional e universalização de direitos, o presente tópico busca pontualidade, e situar os termos econômico-financeiros da relevância da atuação estatal frente ao desenvolvimento urbano. ${ }^{182}$

A ampliação das infraestruturas, e consideradas aqui as infraestruturas urbanas, significa a ampliação da capacidade produtiva nacional, tal como apresentam Dweck e Teixeira (2017;

180 Royer, 2014; 2016; Maricato, 2015; p.51; Klink; Souza, 2017.

${ }^{181}$ Expoente do individualismo metodológico, Przeworski (1985) discute a dimensão coercitiva associada às relações trabalhistas capitalistas, mas também a racionalidade presente na manutenção coletiva da divisão do trabalho nas sociedades capitalistas democráticas do século XX europeu, por exemplo. Apesar dos desafios teóricos impostos à articulação estrutura-agência, também presentes no trabalho de Przeworski, parece pertinente a articulação entre materialismo, história, sociedade e indivíduo em busca de amplas interpretações, necessárias.

${ }^{182}$ Ao situar os termos econômico-financeiros de atuação estatal frente ao desenvolvimento urbano nacional, nos atentaremos principalmente ao desempenho de economia nacional, às fontes de recursos nacionais (recursos orçamentários, FGTS, SBPE), ao setor produtivo da construção civil e ao debate sobre o acesso à moradia digna, elementos amplamente relacionados com o financiamento e entendimento de políticas urbanas e habitacionais no país. No entanto, com atenção ao trabalho de Mioto (2015; pp.89-92), a ampla compreensão dos aspectos econômicos de setor e subsetores da construção civil exigiria o estudo de outros elementos, a exemplo dos fluxos dos capitais internacionais e balança comercial brasileira, também passíveis de compreensão à luz de atuação estatal. Sobre o tema, Mioto (2015; p.92) defende que os "efeitos do aquecimento do setor da construção civil (no início do XXI) são concomitantes a uma piora na inserção externa". 
pp.16-7). Essa questão pode ser desenvolvida sob a ótica setorial (habitação; mobilidade urbana; saneamento básico; energia elétrica, por exemplo), ${ }^{183}$ e de acordo com a espacialização e inserção urbana de determinado investimento público (cf. Isoda, 2013). Ainda, é possível debater o impacto das infraestruturas ao longo do tempo, e sobre a vida das futuras gerações, tal como sugerem Brasil Debate e a Fundação Friedrich Ebert (2018).

O crescimento econômico nacional também se associa à construção de moradias, à mobilidade urbana, ao saneamento básico (Dweck; Rossi, 2019; p.97), ainda que seja necessário qualificar o entendimento de crescimento econômico em associação aos objetivos sociais, tal como argumentam os autores. A ativação do setor da construção civil, por exemplo, impacta a demanda e composição do emprego na economia, e a formalização do emprego significa a ampliação do consumo (Brenck; Carvalho, 2019; p.169).

É interessante entender que a ativação de produção imobiliária residencial, parcela do setor da construção civil, passa também pela tecnologia organizacional (gestão e serviços) nos canteiros de obra, por exemplo (cf. Baravelli, 2014). Há, contudo, indicações de que, mesmo diante da ativação econômica do setor da construção civil, trabalhadores dos canteiros de obra seguem com baixa remuneração e degradadas condições de trabalho, significando acidentes no ambiente de trabalho (Oliveira; Fix, 2017).

Desde a década de 1970, então em contraposição às políticas econômicas implementadas no início do regime militar, argumenta-se que os investimentos em habitação

\footnotetext{
${ }^{183}$ A partir da perspectiva territorial e regional, estudos sobre infraestruturas de transporte apontam: "[...] o investimento público no setor de transportes provoca efeito positivo e estatisticamente significante sobre o desempenho econômico de longo prazo dos estados brasileiros e contribui potencialmente para a redução da desigualdade de renda entre eles" (Bertussi et al., 2011 ;p.89). Vale mencionar, o debate sobre desenvolvimento sustentável com redução de desigualdades deve ser complexificado, com espaço para as divergências. De acordo com Emilio Moran, professor da Universidade Estadual de Michigan: "[...] foram apresentados os resultados de uma pesquisa sobre os processos sociais e ambientais da construção da hidrelétrica de Belo Monte. Uma das principais conclusões foi que as promessas de induzir o desenvolvimento econômico sustentável da região, por meio da geração de empregos e melhorias nos serviços públicos de saneamento, saúde e educação, feitas antes e durante a construção da usina, na qual foram investidos R\$ 42 bilhões, não se concretizaram. Pelo contrário: contribuíram para aumentar o custo de vida e da energia elétrica para a população, agravar problemas nos sistemas de habitação e de água e saneamento, além de levar a uma diminuição da produção de alimentos e da pesca na região", informações extraídas de: <http://agencia.fapesp.br/belo-monte-descumpriu-promessa-de-levardesenvolvimento-sustentavel-a-regiao-amazonica/31374/>, consultado em setembro de 2019.
} 
popular poderiam significar um crescimento econômico nacional mais lento, mas também mais duradouro, com uma melhor distribuição de renda (Bolaffi, 1975; pp.76-7). Esse debate permanece em sociedade brasileira:

Despender recursos em infraestrutura e moradia é o caminho correto não só para conferir autonomia ao dinamismo da economia brasileira, como para alavancar o próprio processo de inovação tecnológica, condição sine qua non para que a economia atinja sua maturidade (Paulani, 2012; p.101).

Aos arquitetos e urbanistas que vivenciaram profissionalmente a década de 2000 e 2010, parece inegável o impacto da ativação da construção civil sobre as relações econômicas, evidente a partir da quantidade de projetos e obras urbanas e habitacionais desenvolvidos no país. ${ }^{184}$ Segundo o Governo Federal, entre 2009 e meados de 2019, foram concluídas 4.628.442 unidades habitacionais pelo PMCMV, contratadas 5.590.573. ${ }^{185}$ De acordo com Maricato (2015): "nossas cidades explodiram". ${ }^{186}$

Ainda que sejam necessários estudos detalhados, argumentos publicizados pela imprensa brasileira apontam elementos da relação econômica estabelecida entre atuação estatal e setor da construção civil.

Entre 2002 e 2012, o número de empregos formais no país cresceu 65,7\%, passou de 28,6 milhões para 47,4 milhões, e o setor da construção civil foi o segmento que mais gerou postos formais de trabalho, crescendo 155\% entre 2002 e 2012. ${ }^{187}$ Em maio de 2014, a Associação Brasileira da Indústria de Materiais de Construção (Abramat) e o Sindicato da Indústria da Construção Civil do Estado de São Paulo (Sinduscon-SP) reduzem estimativa de

\footnotetext{
184 Os dados do IBGE e Cadastro Geral de Empregados e Desempregados (Caged, Secretaria de Previdência e Trabalho do Governo Federal) ilustram o bom desempenho econômico de setor da construção civil no país. Este setor apresenta crescimento acentuado entre 2006 e 2014, com desempenho superior ao acumulado pela economia a partir de 2009. O número de postos de trabalhos formais na construção civil supera a marca de 3 milhões em 2013 e 2014. Dados disponíveis em: <https://www.nexojornal.com.br/expresso/2019/07/21/Como-aconstrução-civil-ajuda-a-explicar-a-crise-brasileira>, consultado em setembro de 2019.

185 Informações disponíveis em: <http://sishab.cidades.gov.br/>, consultado em setembro de 2019.

186 Maricato (2015) discute as cidades brasileiras também com atenção à perspectiva econômica nacional, por exemplo.

${ }^{187}$ <https://www.valor.com.br/brasil/3357378/empregos-formais-no-pais-crescem-657-em-dez-anos-indicaibge>, consultado em setembro de 2019.
} 
crescimento do PIB da construção, de 2,8\% para algo entre 1 e $2 \% .{ }^{188}$ No segundo trimestre de 2014, segundo dados apresentados pelo IBGE, o setor da construção civil verifica retração de 8,7\% de seu PIB, pior resultado desde o primeiro trimestre de $2002 .{ }^{189}$ Segundo pesquisa desenvolvida por Sinduscon-SP em parceria com a Fundação Getúlio Vargas, ao longo de 2014 há corte de 14,8 mil postos de trabalho na construção civil, em 2013 haviam sido gerados 141 mil vagas de trabalho. ${ }^{190}$ Em fevereiro de 2015, é informado que durante o ano de 2014 há o corte de 18 mil postos de trabalho na construção civil, dentre as causas apresentadas por presidente do Sinduscon-SP encontram-se: atrasos de pagamentos dos governos da União e Estados, adiamento de ordens de serviços para o início da execução de obras e até cancelamento de contratos em decorrência da Lava-Jato. ${ }^{191}$

O desenrolar da Operação Lava-Jato afeta Petrobrás e construtoras, e agentes privados estimam uma queda de cerca de $15 \%$ nos investimentos em infraestrutura no país durante o ano de 2015. ${ }^{192}$ Em março de 2015 a manchete é: "Setor da construção deve ter 'biênio perdido'”. 193 Em março de 2015, o então Ministro das Cidades, Gilberto Kassab, mesmo em cenário de ajustes fiscais federais, apresenta o PMCMV enquanto prioridade do governo Dilma Rousseff, e defende que o PMCMV serviria para alavancar a economia, gerar empregos e cumprir sua função enquanto política social. ${ }^{194} \mathrm{Em}$ março de 2015, o então Ministro do Trabalho, Manoel Dias, afirma que o setor da construção civil fecha 33,3 mil postos de trabalho

\footnotetext{
188 <https://www.valor.com.br/empresas/3566712/abramat-e-sinduscon-sp-reduzem-previsao-de-crescimento>, consultado em setembro de 2019.

$189<$ <https://www.valor.com.br/brasil/3675334/construcao-civil-recua-87-e-tem-maior-queda-desde-2002>, consultado em setembro de 2019.

$190 \quad<$ https://www.valor.com.br/brasil/3859466/emprego-na-construcao-civil-cai-em-2014-diz-sinduscon>, consultado em setembro de 2019.

191 <https://www.valor.com.br/empresas/3888954/nivel-de-emprego-na-construcao-civil-cai-apos-dois-anos-dealta>, consultado em setembro de 2019.

192 <https://www.valor.com.br/brasil/3881606/lava-jato-derruba-projecoes-de-pib-e-investimento>, consultado em setembro de 2019.

193 <https://www.valor.com.br/brasil/3935804/setor-de-construcao-deve-ter-bienio-perdido>, consultado em setembro de 2019.

194 <https://www.valor.com.br/brasil/3957038/kassab-diz-que-nova-fase-do-minha-casa-minha-vida-vai-gerarempregos, consultado em setembro de 2019.
} 
entre janeiro e fevereiro, e anuncia esforços em torno da compreensão dos impactos da LavaJato sobre economia. ${ }^{195}$

No Pará os investimentos em infraestrutura amortecem os efeitos da retração econômica nacional e significam um crescimento de 8,7\% durante o primeiro trimestre de 2015, em comparação com o mesmo período de 2014. ${ }^{196}$ Em junho de 2015, o Sinduscon-SP apoia publicamente o pacote de investimentos de $\mathrm{R} \$ 198,4$ bilhões apresentado pelo Programa de Investimento em Logística (PIL) do governo federal, mas ainda cobra medidas de estímulo à construção civil brasileira. ${ }^{197}$

Em agosto de 2015, o Sinduscon-SP projeta queda de 7\% do PIB da construção civil, e o setor de infraestruturas seria o mais prejudicado: "O governo não está contratando e tem atrasado os pagamentos", diz Ferraz Neto, além disso, segundo representante da FGV, o mercado imobiliário habitacional já sente os impactos da queda da renda real e restrições do crédito. ${ }^{198}$ Em setembro de 2015, a confiança dos empresários da construção civil registra queda, reflexo dos cortes de investimentos no PMCMV e PAC e dificuldades no acesso ao crédito. $^{199}$

Em outubro de 2015, o IPEA indica impacto de Operação Lava-Jato sobre o setor da construção civil. ${ }^{200}$ Em dezembro de 2015, o Sinduscon-SP indica encolhimento de 8\% do setor da construção civil durante o ano, indica o cenário político, a diminuição da renda das famílias, retiradas de recursos das poupanças, retração de crédito e investimentos, atrasos nos pagamentos PMCMV e PAC como fatores relacionados. ${ }^{201}$ Em janeiro de 2016, o Sinduscon-SP

\footnotetext{
195 <https://www.valor.com.br/brasil/3963526/ministerio-pretende-medir-impacto-da-lava-jato-na-reducao-doemprego-formal>, consultado em setembro de 2019.

196 <https://www.valor.com.br/brasil/4071964/obras-de-infraestrutura-contem-retracao-no-para>, consultado em setembro de 2019.

197 <https://www.valor.com.br/empresas/4086510/para-sinduscon-sp-investimentos-do-pacote-de-concessoessao-positivos>, consultado em setembro de 2019.

198 <https://www.valor.com.br/brasil/4165968/sinduscon-sp-preve-queda-maior-para-pib-da-construcao-desteano>, consultado em setembro de 2019.

$199<$ <ttps://www.valor.com.br/brasil/4241844/cortes-no-pac-e-minha-casa-minha-vida-afetam-confianca-daconstrucao>, consultado em setembro de 2019.

200 <https://www.valor.com.br/brasil/4289144/lava-jato-contribuiu-para-o-aumento-do-desemprego-diz-ipea>, consultado em setembro de 2019.

201 <https://www.valor.com.br/empresas/4346912/setor-de-construcao-encolhe-8-neste-ano-e-preve-queda-de5-em-2016>, consultado em setembro de 2019.
} 
indica o fechamento de 483 mil postos de trabalho na construção civil durante o ano de 2015, equiparando-se ao patamar de maio de 2010. ${ }^{202}$ Em abril de 2016, Ana Maria Castelo da FGV indica a importância das obras de infraestruturas e BNDES para a recuperação do setor de construção civil, apesar do cenário de ajustes fiscais. ${ }^{203}$

Em maio de 2016, "o mercado imobiliário aposta em projetos de moradia popular e social para estancar a queda nas atividades do setor". ${ }^{204}$ Em julho de 2016, "construção apoia Temer, mas quer obras". ${ }^{205}$ Em dezembro de 2016, o vice-presidente de habitação do Sinduscon-SP, Ronaldo Cury, afirma que "o setor chegou ao fundo do poço", e o presidente do Sinduscon-SP, José Romeu Ferraz Neto, defende as reformas da previdência, trabalhista e tributária, para além da retomada das obras de infraestrutura e redução da taxas de juros, por exemplo. 206

Em abril de 2019, "CCR quer investir em novos projetos de infraestrutura", e há indicações de atuação da empresa em rodovias, aeroportos e sistemas de mobilidade urbana, por exemplo. ${ }^{207}$ Em abril de 2019, "A agenda de investimentos em infraestruturas está no topo das prioridades das agências multilaterais no Brasil”. ${ }^{208}$ Em junho de 2019, Claudio Frischtak, presidente da Inter B Consutoria Internacional afirma: "o investimento em infraestrutura deveria ser política de Estado, não de governo". ${ }^{209}$

202 <https://www.valor.com.br/empresas/4412706/construcao-fecha-483-mil-postos-de-trabalho-em-2015-dizsinduscon-sp>, consultado em setembro de 2019.

203 <https://www.valor.com.br/brasil/4540109/retomada-de-obras-exige-recursos-do-banco-diz-fgv>, consultado em setembro de 2019.

204 <https://www.valor.com.br/empresas/4567719/continuidade-do-minha-casa-minha-vida-e-estrategica>, consultado em setembro de 2019.

205 <https://www.valor.com.br/brasil/4643527/construcao-apoia-temer-mas-quer-obras>, consultado em setembro de 2019.

$206<$ https://www.valor.com.br/empresas/4793401/sinduscon-sp-emprego-no-mercado-imobiliario-cai-quase-18em-10-meses>, consultado em setembro de 2019.

207 <https://www.valor.com.br/empresas/6202381/ccr-quer-investir-em-novos-projetos-de-infraestrutura>, consultado em setembro de 2019.

208 <afetam-confianca-da-construcao deveria ser pol da INter tancar a queda nas atividades do setor" cende que o PMCMV serviria parhttps://www.valor.com.br/financas/6203055/infraestrutura-e-alvo-prioritario-em-atuacaode-agencias>, consultado em setembro de 2019.

209 <https://www.valor.com.br/brasil/6300911/pais-precisa-investir-4-do-pib-em-infraestrutura-diz-consultor>, consultado em setembro de 2019. 
Há evidências sobre a relação econômica estabelecida entre atuação estatal e setor da construção civil. Contudo, é socialmente possível alinharmos o crescimento econômico à pobreza. Neste sentido, e conforme Royer (2009), o debate sobre os termos econômicos de atuação estatal sobre o desenvolvimento urbano exige refinamento, com atenção aos aspectos financeiros e suas relações sociais.

O Plano Nacional de Habitação (Brasil, 2009; pp.70-8) delineia as necessidades habitacionais do país. Desenvolvido entre 2007 e 2008, ainda não eram claros os desdobramentos da crise internacional sobre a economia brasileira. Apesar de salvaguardas a respeito desse tema, o plano adota o crescimento médio do PIB de 4\% e a premissa de melhoria da renda das camadas mais pobres no país até 2023, variáveis relevantes à construção de cenários habitacionais, urbanos e financeiros então apresentados pelo plano. O PlanHab projeta necessidade global de 35 milhões de unidades habitacionais até 2023, considerados o déficit acumulado e demanda futura. Em relação aos recursos orçamentários, um primeiro cenário estima o investimento não-oneroso federal de $\mathrm{R} \$ 85,5$ bilhões, investimento não-oneroso de estados e municípios equivalente a $\mathrm{R} \$ 53,2$ bilhões até 2023. Um segundo cenário incorpora a proposta da PEC da Moradia Digna, o que significaria estabelecer 2\% dos gastos orçamentários federais e $1 \%$ dos gastos orçamentários de estados e municípios ao atendimento das necessidades habitacionais, é esta a estratégia não efetivada de vinculação de receita dos orçamentos públicos para habitação. O segundo cenário significaria a alocação de $\mathrm{R} \$ 174,8$ bilhões de recursos não-onerosos federais, $R \$ 45,3$ bilhões por estados, $R \$ 32,7$ bilhões por municípios com vistas ao atendimento das necessidades habitacionais no país. Segundo o plano, apenas o segundo cenário apresentaria um nível satisfatório de atendimento das necessidades habitacionais, representando alguma estabilidade e previsibilidade em termos de alocação de recursos orçamentários, frente a necessidades que são permanentes. ${ }^{210}$

\footnotetext{
${ }^{210}$ A solução do financiamento habitacional pelo PlanHab dá-se a partir de: (i) ampliar os recursos não-onerosos e sua destinação ao atendimento da população de mais baixa renda; (ii) reduzir os custos e ampliar a alocação dos recursos do FGTS, também em termos de subsídio às famílias; (iii) articular FGTS e SNHIS; (iv) reduzir os riscos de agentes financeiros e ampliar o atendimento de baixa renda com alto risco de crédito; (v) direcionar os recursos do SBPE ao atendimento de rendas mais altas (Brasil, 2009; p.84). Desse modo, o PlanHab apresenta avaliações sobre o FGTS e SBPE. As avaliações em torno do FGTS buscam, na administração desses recursos, aliar saúde financeira de poupança compulsória à ampliação de investimentos em habitação e saneamento, debate que
} 
A ampliação dos recursos não-onerosos é uma estratégia essencial para o sucesso das metas do Plano Nacional de Habitação. [....] a habitação é uma questão de Estado, com foco nos setores de baixa renda, onde se concentra o déficit, que não tem capacidade de assumir parcial ou integralmente um financiamento, nem de pagar o aluguel de uma moradia digna, direito garantido constitucionalmente (Brasil, 2009; p.85; grifo nosso).

Ao assumir como referência a experiência de financiamento do programa Minha Casa, Minha Vida entre 2010 e 2014, Givisiez et al. (2018) apresentam estimativas da necessidade de financiamento imobiliário habitacional via crédito, poupança e subsídio para a aquisição de domicílios a partir de valores de produção habitacional e faixas de rendimento familiar. As estimativas apontam a demanda nacional pela construção de aproximadamente 25 milhões de moradias entre 2016 e 2040 (Givisiez et al., 2018; pp.247). Segundo esse estudo (pp.305-6), e com atenção à projeção de demanda futura no país, seriam necessários $R \$ 130$ bilhões de reais por ano de empréstimos via crédito imobiliário; a disponibilidade de poupança prévia foi estimada em $\mathrm{R} \$ 34,6$ bilhões por ano, considerados ativos imobiliários, fundos financeiros, poupança depositada em contas do FGTS; os subsídios públicos necessários estão estimados em $\mathrm{R} \$ 28,5$ bilhões por ano, considerando-se tanto aportes orçamentários dos governos quanto empréstimos a fundo perdido do FGTS, por exemplo. A necessidade de subsídios seria decrescente ao longo do tempo e segundo estimativas apresentadas.

Relevantes diagnósticos assumem o constante incremento da renda domiciliar dos mais pobres, com decorrência sobre as estimativas em torno do subsídio público, por exemplo. ${ }^{211}$ Outros estudos, contudo, apontam a não linearidade progressiva da renda familiar dos mais pobres no país. Segundo estudo desenvolvido pela Fundação Getúlio Vargas, apresentado por Marcelo Neri em 31 de agosto de 2018, a pobreza no Brasil volta a crescer entre 2014 e 2017,

confere espaço à ampliação de remuneração de contas e eventuais aumentos de saques, por exemplo. As avaliações em torno do SBPE consideram a estabilidade de moeda brasileira, a taxa Selic, a renda dos brasileiros, o aumento de depósitos em poupanças e a segurança jurídica de operações de crédito imobiliário, por exemplo. A estabilidade macroeconômica é fundamental para o entendimento de operações de crédito de longo prazo. Segundo o plano, o SBPE seria um funding capaz de financiar 6,3 milhões de UHs, desde que suportado por capacidade de produção e mercado. A calibração e focalização de SBPE poderia aliviar as disputas em torno do FGTS que, por sua vez, poderia ampliar o atendimento da baixa renda (Brasil, 2009; pp.78-81).

${ }^{211}$ Givisiez et al., 2018; p.297; Brasil, 2009; p.69 assumem a melhoria da renda das camadas mais pobres. 
o que significa 6,3 milhões de novos pobres, e um total de 23,3 milhões de pobres no país em 2017.212

A despeito de divergências acerca da mensura da distribuição da riqueza no país, é notória a constante necessidade de investimentos, crédito e subsídios públicos para a ampliação do acesso ao mercado imobiliário habitacional e o atendimento das necessidades habitacionais no país. Os recursos financeiros são centrais à política pública urbana e habitacional. Mesmo diante de crescimento econômico nacional, a detenção de recursos financeiros pelos mais pobres nunca foi suficiente à compra, acesso à moradia ou universalização da moradia digna no país.

Subjacente às avaliações apresentadas por esta dissertação, verifica-se a ideia de que a moradia digna está associada ao acesso à infraestrutura e aos serviços urbanos básicos. Neste sentido, a relevância econômica de atuação estatal frente ao desenvolvimento urbano incorpora o debate sobre as infraestruturas e serviços nas cidades brasileiras.

Segundo Gambiagi e Além (2011; pp.4-10), a relevância econômica da atuação estatal sobre o urbano pode ser compreendida a partir das próprias dinâmicas de mercado. É dificultoso impedir que determinado indivíduo usufrua de bens públicos, a exemplo do sistema viário ou sistema de iluminação pública, o que significaria a ineficiência de dinâmicas de mercado. Ainda, em determinados mercados, a operação de um grande número de empresas pode significar custos de produção mais altos, podendo ser economicamente interessante a existência de monopólio, a exemplo da distribuição de energia elétrica, por exemplo. A premissa de universalização do acesso a bens e serviços também pode significar o baixo interesse do setor privado. Neste sentido, assumem-se as ineficiências de mercado, e destaca-se a relevância de atuação estatal frente à provisão de bens e serviços públicos, sendo a provisão financiada

\footnotetext{
212 Considera-se $\mathrm{R} \$ 233$ reais por mês por pessoa a linha da pobreza. A apresentação "Qual foi o impacto da crise sobre a pobreza e a distribuição de renda?" encontra-se disponível em: $<$ https://www.cps.fgv.br/cps/bd/slides/SLIDE-NOTADis_Pobreza_Desigualdade_Crise_Neri_FGV_Social_FGV.pdf>, consultado em julho de 2019.
} 
pela cobrança compulsória de impostos, por exemplo. ${ }^{213}$ Há ainda outras alternativas às ineficiências de mercado, a exemplo da regulação e fiscalização de atividades privadas.

De acordo com Brasil (2013; pp.140-1), a respeito do saneamento básico no país:

Considera-se que os investimentos em medidas estruturais correspondem aos totais investidos em ações relativas à expansão da produção e distribuição de água; da coleta, interceptação, transporte e tratamento dos esgotos; de aterros sanitários e usinas de triagem e compostagem e também a uma parcela de 30\% dos investimentos em reposição nesses componentes. [...] serão necessários cerca de $\mathrm{R} \$$ 508,5 bilhões em medidas estruturais e estruturantes até 2033. No que se refere à origem dos investimentos, estima-se que $59 \%$ dos recursos (R\$2 299,9 bilhões) sejam provenientes dos agentes federais e $R \$ 208,6$ bilhões sejam aportados por agências internacionais, prestadores de serviços, orçamentos estaduais e municipais e setor privado, na forma de investimentos diretos ou de contrapartidas.

Em suma, e mesmo que de modo expedito, a presente seção alinha-se à tese de que o Estado exerce um papel de destaque na economia, também conformando instituições básicas e necessárias ao funcionamento desta, a exemplo da regulação das relações trabalhistas. ${ }^{214}$

Especificamente, argumenta-se a relevância econômica da atuação estatal frente ao desenvolvimento urbano a partir de três eixos principais:

(i) Produção, emprego e renda: Estruturação, articulação, indução e financiamento de obras de infraestrutura urbana e habitacional, com implicações sobre a sofisticação e concorrência de setor produtivo da construção civil, e sobre a produtividade, a oferta de empregos e o consumo no país; cabe aqui destacar a centralidade de atuação estatal frente à fiscalização de obras e relações trabalhistas, por exemplo;

\footnotetext{
${ }^{213}$ Gambiagi et al., 2011 apresentam que a atuação estatal através da política fiscal abrange três funções básicas, alocativa, distributiva e estabilizadora. A alocativa relaciona-se com o fornecimento de bens públicos. A distributiva visa a ajustes na distribuição de renda. A estabilizadora objetiva, por meio da intervenção estatal na economia, um alto nivel de emprego, estabilidade de preços e crescimento econômico. Relativo a isso, literatura específica avançará no debate sobre tamanho relativo do Estado a partir das ações redistributivas (Meltzer; Richard, 1981, por exemplo), e nos termos da economia de bem-estar social a respeito da infraestrutura e serviços urbanos (Soares, 2017, por exemplo). Soares (2017) debate o valor de mercado de acesso à eletricidade, água, esgoto, gás e telefonia fixa, com avaliação sobre a progressividade e valor de mercado desses serviços.

${ }^{214}$ Premissa adotada pela teoria da regulação. Ver Boyer, 2009.
} 
(ii) Mercado imobiliário habitacional e mercado fundiário: Promoção de investimentos, créditos e subsídios habitacionais, além da regulação, gestão e fiscalização do uso do solo urbano, por exemplo, e a articulação desses ao atendimento das necessidades urbanas e habitacionais, presentes e futuras; ${ }^{215}$

(iii) Infraestrutura e serviços urbanos: Provisão, regulação e fiscalização de infraestrutura, bens e serviços urbanos, com atenção à universalização de seu acesso.

Em termos de desenvolvimento urbano com universalização de direitos, mas também em termos econômicos, sempre importa debater onde (Aonde na cidade?) e como (Qual modelo de cidade? Para quem?) se dá a atuação estatal, ou seja, a alocação de recursos financeiros também em termos socioespaciais. ${ }^{216} \mathrm{~A}$ literatura mobilizada por esta dissertação sugere o caráter duradouro de relevância econômica de atuação estatal frente ao desenvolvimento urbano brasileiro.

\footnotetext{
${ }^{215}$ É necessário reconhecer a importância de regulação para o mercado fundiário e imobiliário habitacional. Contudo, o mercado fundiário ou imobiliário habitacional não é um espelhamento das normas urbanísticas, o caso dos condomínios fechados na região leste do Distrito Federal é um exemplo disso. Sobre isto, ver Vianna (2011), por exemplo.

${ }^{216}$ Ver Wissenbach, 2018, por exemplo. Ainda, a experiência dos CEUs (Centro Educacional Unificado - Prefeitura do Município de São Paulo) indica a arquitetura e a inserção urbana enquanto dimensão da qualidade de investimentos públicos, ainda que a associação entre políticas educacionais e infraestrutura urbana permaneceu central para avanços socioespaciais associados aos CEUs. Sobre os CEUs ver Oliveira (2017).
} 


\section{Finanças públicas a partir do desenvolvimento urbano}

A dissertação direciona-se à articulação entre urbano e atuação estatal a partir das finanças públicas. As finanças públicas não são condição única e suficiente à compreensão do urbano, contudo, as finanças públicas são condição à atuação estatal. Neste sentido, e também de acordo com literatura consultada, o estudo das finanças públicas demonstra-se pertinente ao debate sobre o urbano, e sua importância está organizada em dois eixos principais: (i) expressão de processos sociais, políticos e econômicos, com implicações sobre o fluxo de riqueza nacional e o urbano; (ii) possibilidade ao problema urbano. ${ }^{217} \boldsymbol{A}$ articulação entre urbano, atuação estatal e finanças públicas será, assim, entendida a partir do financiamento fiscal do desenvolvimento urbano, ou seja, a partir do gasto público no Brasil. ${ }^{218}$

\subsection{Investigação sobre as finanças públicas}

\subsubsection{Pergunta de pesquisa}

Considerada a articulação entre urbano, atuação estatal e finanças públicas, a presente dissertação indaga: Qual financiamento fiscal do desenvolvimento urbano é possível no Brasil? O presente estudo está inserido na articulação atuação estatal, finanças públicas e desenvolvimento urbano. O centro argumentativo é o desenvolvimento urbano, e por isso a pergunta de pesquisa refere-se a seu financiamento. Se o centro argumentativo fosse o Estado, a pergunta poderia referir-se ao gasto público. Por financiamento nos referimos ao ato de prover recursos financeiros, mais especificamente, à alocação de recursos orçamentários com vistas à promoção do desenvolvimento urbano no Brasil.

Responder à pergunta de pesquisa demanda compreender como e qual financiamento fiscal do desenvolvimento urbano ocorre no Brasil. Para tal, é necessário estabelecer definições, reconhecer premissas e apresentar as ressalvas sobre a pesquisa. Além disso, é central ao

\footnotetext{
217 O enfoque de pesquisa é o financiamento do desenvolvimento urbano, e menos sobre os impactos desse financiamento.

${ }^{218}$ A presente dissertação entende o gasto público como a execução de recursos orçamentários, principalmente. Essa relação é evidenciada pelo método de pesquisa, debatido adiante.
} 
debate avaliação quali-quantitativa precisa sobre a alocação das finanças públicas a partir da perspectiva sobre o urbano.

2.1.2 Definições, premissas, ressalvas e considerações gerais sobre a pesquisa

O presente trabalho adota os recursos orçamentários enquanto objeto de pesquisa. $\mathrm{O}$ estudo é focalizado sobre o controle, planejamento e execução de Orçamento Geral da União (2000-2016) e a realização de receita pela prefeitura do município de São Paulo (2003-2016).

A pesquisa parte da associação entre serviços urbanos e infraestrutura urbana e habitacional. Desse modo, por desenvolvimento urbano entende-se a associação entre diferentes eixos, elencados adiante:

(i) Habitação: provisão de unidades habitacionais, subsídio ao acesso a unidades habitacionais, urbanização de assentamentos precários, melhoria condições habitabilidade, produção de lotes urbanizados, regularização fundiária, assistência técnica à autoconstrução e ao mutirão;

(ii) Saneamento básico: abastecimento de água - incluída a construção de cisternas, coleta e tratamento de esgoto sanitário, drenagem urbana, coleta, tratamento e destinação final de resíduos sólidos;

(iii) Mobilidade urbana: sistemas de transporte ferroviário urbano de passageiros, sistemas de trens urbanos, malha metroviária, corredores estruturais de transporte coletivo urbano, acessibilidade para pessoas com restrição de mobilidade e deficiência;

(iv) Energia elétrica: oferta de energia elétrica, acesso a energia elétrica, concessão e fiscalização dos serviços de energia elétrica;

(v) Infraestrutura urbana: implantação ou melhoria de obras de infraestrutura urbana, mas em geral pouco qualificada pela execução orçamentária. Essa atuação também contempla qualificação do espaço público e preservação do patrimônio material, por exemplo; 
(vi) Planejamento e gestão pública: ${ }^{219}$ pagamento de pessoal ativo da União, gestão e administração de programas e unidades, capacitação técnica de recursos humanos, estudos técnicos e desenvolvimento de planos, gerenciamento e fiscalização de cadastros, georreferenciamento de imóveis e malha fundiária, sistemas de informação, administração do patrimônio imobiliário da União;

(vii) Operações especiais: programas 0904 - Operações Especiais: Outras Transferências; 0909 - Operações Especiais: Outros Encargos Especiais; e 0911 Operações Especiais - Remuneração de Agentes Financeiros. O estudo exploratório demonstra que a maioria das ações executadas no âmbito desses programas não se refere ao desenvolvimento urbano. Contudo, algumas ações financiadas no âmbito desses programas ainda não poderiam ser descartadas por nosso estudo, dado que se referem à implantação do metrô de Distrito Federal e ao subsídio à política de crédito imobiliário habitacional, por exemplo (programa Minha Casa, Minha Vida).

A articulação entre urbano, atuação estatal e finanças públicas sinaliza a associação de categorias enumeradas acima. Por exemplo, a urbanização de um assentamento precário pode significar tanto a produção de novas unidades habitacionais, como a construção de infraestruturas de esgotamento sanitário e abastecimento de água. $\mathrm{O}$ acesso a serviços urbanos pode estar associado ao sistema de mobilidade urbana, por exemplo. A preservação de um patrimônio histórico pode estar articulada à melhoria de infraestrutura de drenagem urbana, iluminação pública e a uma gestão pública continuada. As categorias, ou eixos do desenvolvimento urbano, podem então ser entendidas enquanto categorias heurísticas e, face à materialidade, complexidade e amplitude do urbano brasileiro, o debate sobre financiamento fiscal do desenvolvimento urbano demanda a articulação entre essas. De qualquer modo, para maior inteligibilidade de evidências primárias apresentadas por esta dissertação, será adotada a classificação apresentada acima.

\footnotetext{
${ }^{219}$ Assim como apresenta Core (2011; p.13), o campo da contabilidade pública demonstra preocupação sobre uma melhor mesura a respeito dos gastos em capital humano e capital fixo, elementos necessários a uma adequada atuação estatal. Agradecemos aos comentários de Fábio Pereira dos Santos.
} 
Em termos de referencial qualitativo, com atenção à consolidação e articulação de atuação estatal frente ao desenvolvimento urbano, também entendida a partir das finanças públicas, a atuação estatal consolidada e articulada frente ao desenvolvimento urbano não é marcada pela desassociação ou descontinuidade entre alocação de recursos, projetos e obras, por exemplo. A desassociação ou descontinuidade de atuação estatal pode impactar negativamente o urbano e representar tendência de má gestão das finanças públicas, isso pois o urbano se relaciona com a materialidade da provisão da infraestrutura urbana e habitacional nas cidades brasileiras. Não é economicamente racional o asfaltamento desassociado do sistema de saneamento básico, por exemplo. Tampouco é econômica ou socialmente racional a urbanização de apenas parcela de assentamento precário, prática que conduz ao acirramento de conflitos e disputas pelo espaço na cidade, também entre os mais pobres, por exemplo. A oferta e provisão de serviços e infraestrutura urbana e habitacional associam-se ao debate sobre o problema urbano brasileiro.

Desse modo, o financiamento fiscal do desenvolvimento urbano também está associado ao debate sobre (i) articulação, indução, financiamento de obras; (ii) promoção de investimentos, créditos e subsídios; (iii) regulação, gestão e fiscalização de atividades públicas e privadas, bens e serviços urbanos, e à articulação entre esses.

A ideia de problema urbano remete às necessidades habitacionais e ao não acesso aos serviços e infraestruturas urbanas. Sobre isso, destaca-se a correlação entre riqueza, renda e acesso a serviços e infraestruturas urbanas e habitacional no país. ${ }^{220}$ É adotada a universalização do acesso aos serviços e infraestruturas urbanas e habitacional enquanto horizonte normativo e, neste sentido, a atuação estatal é aqui entendida enquanto estratégia central à materialização desse horizonte, seja em termos econômicos ou sociais. O direito social à moradia poderia significar a efetiva responsabilização de Estado frente à resolução do problema urbano brasileiro. ${ }^{221}$ O presente trabalho assume o caráter duradouro de relevância de atuação estatal frente ao desenvolvimento urbano brasileiro no sentido dessa universalização.

\footnotetext{
220 Arretche, 2015.

221 Além disso, a adoção de atuação estatal enquanto principal alternativa ao problema urbano associa-se ao debate sobre controle social, por exemplo, o que pode representar maior tendência ao igualitário.
} 
Sobre as finanças públicas, não há vinculações de receitas ou vinculação de recursos orçamentários ao financiamento do desenvolvimento urbano a partir de desenho fiscal e tributário implementado por meio e após a Constituição de 1988. O que há é a ampliação das responsabilidades e regulamentação de possibilidades ao financiamento urbano pelos municípios a partir do capítulo da reforma urbana da Constituição Federal e por meio do Estatuto da Cidade. ${ }^{222}$ Ainda, as recentes mudanças no regime fiscal brasileiro tendem a exercer impacto direto sobre as finanças públicas e atuação estatal, já que é prevista a intensificação de conflitos e impasses distributivos em cenário de austeridade fiscal permanente, determinado para os próximos 20 anos por meio da Emenda Constitucional 95 de 2016.

Apesar da presente pesquisa dedicar-se ao estudo das finanças públicas, com destaque aos recursos orçamentários, é histórica a vinculação das políticas urbanas e habitacionais aos recursos onerosos, dentre os quais destacam-se o Fundo de Garantia do Tempo de Serviço e o Sistema Brasileiro de Poupança e Empréstimos. ${ }^{223}$ Além disso, despontam as experiências de concessão e parcerias público-privadas nas cidades do país, que deslocam a atuação estatal em direção à regulação e ao setor privado, e complexificam o debate sobre atuação estatal, finanças públicas e desenvolvimento urbano. 224

\subsection{Método de pesquisa sobre as finanças públicas}

A pesquisa é desenvolvida a partir de problematização teórica e investigação empírica, e a partir das relações entre essas. A investigação empírica desenvolve-se de três modos: (i) estudo documental; (ii) abordagem exploratória; (iii) estudo de caso.

\footnotetext{
222 Cf. Ipea, 2011 e Santos, 2012, por exemplo.

${ }^{223}$ Cf. Royer, 2009.

224 Garson (2018; p.172) referencia a dificuldade na obtenção de dados necessários à avaliação de parcerias público-privadas no país, por exemplo.

Segundo noticiado, com base em dados apresentados pela consultoria Radar PPP, "em meio à crise fiscal, os contratos de PPPs crescem 162,5\%". Segundo esses dados, o número de projetos lançados em 2015 é de 108 , em 2019 é de 219. O lançamento de licitações em 2015 é de 11, em 2019 é de 139. A assinatura de contratos em 2015 é de 18. Durante o primeiro semestre de 2019, são assinados 42 contratos, e os investimentos associados aos objetos desses contratos são da ordem de 25 bilhões de reais. Informações disponíveis em <https://valor.globo.com/brasil/noticia/2019/10/03/em-meio-a-crise-fiscal-contratos-de-ppps-crescem1625.ghtml>, link consultado em outubro de 2019.
} 
O estudo documental é orientado pelo estudo sobre o controle parlamentar do gasto público federal e sobre as peças orçamentárias da União. O estudo documental é, nesta pesquisa, essencialmente qualitativo, subsidia e articula-se aos demais métodos de pesquisa, com atenção à abordagem exploratória. De modo geral, o estudo documental visa contribuir para a definição de recorte de pesquisa, mas também para a interpretação processual sobre os dados orçamentários.

A abordagem exploratória destina-se ao estudo da execução do Orçamento Geral da União entre 2000 e 2016. Essa abordagem associa-se à relevância de esfera federal em estrutura federativa brasileira, central para a compreensão de concentração e redistribuição de riqueza pública, políticas de crédito e fiscal, indução de capacidades administrativas subnacionais, formulação e regulação de políticas públicas, por exemplo.

O estudo de caso destina-se ao estudo da receita realizada de prefeitura do município de São Paulo. Também é considerada a responsabilização de esfera local frente ao desenvolvimento urbano e execução de políticas públicas após a Constituição Federal de 1988.

Em ambos momentos, abordagem exploratória e estudo de caso, busca-se a compreensão sobre o financiamento fiscal do desenvolvimento urbano. Vale lembrar, em termos de atuação estatal e a respeito da organização territorial do poder no Brasil, o desenvolvimento urbano é uma competência concorrente, ou seja, de acordo com a Constituição de 1988 pode ser tratado pelas esferas federal, estadual e municipal.

A análise dos resultados da pesquisa estrutura-se a partir da sistematização e síntese de dados primários. Cada uma das abordagens de investigação empírica desvela diferentes questionamentos acerca do urbano, atuação estatal e finanças públicas no Brasil, favorecendo o debate multifacetado a partir da pergunta da pesquisa. Desse modo, a pesquisa é capaz de uma abordagem quali-quantitativa suficiente a sua pergunta, sendo a abordagem construída à luz dos estudos urbanos. A articulação entre teoria e investigação empírica possibilita o debate sobre o financiamento fiscal do desenvolvimento urbano possível no Brasil. 


\subsubsection{Estudo documental}

\subsubsection{Controle parlamentar do gasto público federal}

A Câmara dos Deputados Federais, o Senado Federal, e também o Congresso Nacional contam com instituições específicas ao estudo, revisão e controle externo e horizontal das finanças e do gasto público federal. Esse controle é dimensão efetiva do princípio democrático da separação de poderes e fundamental função do poder legislativo, mesmo que o controle de gasto público não seja função exclusiva do poder legislativo. O controle parlamentar do gasto público contribui, dentre outros, para a produção e publicização de informações relativas à administração pública, fornecendo evidências para o estudo das relações estabelecidas entre os diferentes poderes no âmbito federal, tal como se verifica em portais eletrônicos da Câmara dos Deputados Federais, Senado Federal, Congresso Nacional. ${ }^{225}$

A Comissão Mista de Planos, Orçamentos Públicos e Fiscalização (CMO) do Congresso Nacional publiciza em seu site estudos a respeito dos Planos Plurianuais, Leis de Diretrizes Orçamentárias, e Leis Orçamentárias Anuais, por exemplo. A Consultoria de Orçamentos, Fiscalização e Controle (CONORF) do Senado Federal publiciza estudos a respeito de Meta Fiscal, Adequação Orçamentária e Financeira, além de uma série de notas técnicas e estudos temáticos orçamentários periodicamente produzidos. A Consultoria de Orçamento e Fiscalização Financeira (CONOF) da Câmara dos Deputados Federais publiciza estudos a respeito da Meta Fiscal, Emendas Parlamentares à legislação orçamentária, além de uma série de notas técnicas e estudos temáticos orçamentários.

A CONORF e a CONOF são unidades técnicas do poder legislativo e contribuem com a prestação de serviços de consultoria e assessoramento técnico orçamentário, de fiscalização e de controle público. Ainda, contribuem enquanto assessoramento à CMO e outras comissões, aos parlamentares, à coordenação e ao processamento técnico e operacional de projetos de legislação orçamentária, dentre outros.

225 < https://www2.camara.leg.br/a-camara/estruturaadm/diretorias/diretoria-legislativa/estrutura1/conof/consultaconvenios.html>; < https://www12.senado.leg.br/orcamento>;

<https://www2.camara.leg.br/atividade-legislativa/comissoes/comissoes-mistas/cmo>, links consultados em fevereiro de 2020. 
A CMO, por sua vez, é a comissão exclusivamente responsável por recepcionar as proposições de executivo relativas à legislação orçamentária federal, tratando-se de órgão legislativo permanente do Congresso Nacional, composta por Deputados Federais e Senadores, competente pelo exame e parecer a respeito do planejamento, acompanhamento e fiscalização orçamentária, por exemplo. A CMO é composta por 40 membros titulares, 30 deputados federais e 10 senadores, ao relator também compete a apresentação de emendas próprias e se assim desejado.

O gasto público brasileiro é autorizado por três peças orçamentárias, o Plano Plurianual (PPA), a Lei de Diretrizes Orçamentárias (LDO), e a Lei Orçamentária Anual (LOA), modelo replicado por esferas federal, estadual e municipal, e também pelo distrito federal.

Com atenção ao financiamento fiscal do desenvolvimento urbano e ao caráter estratégico e de médio prazo associado ao PPA, é aqui avaliado o controle parlamentar sobre os projetos de lei dos Plano Plurianuais (PPA), possível a partir de relatórios desenvolvidos pela Comissão Mista de Planos, Orçamentos Públicos e Fiscalização (CMO) do Congresso Nacional entre os anos de 1999 e 2015. O estudo dos relatórios parlamentares subsidia, em termos qualitativos, a interpretação de execução do Orçamento Geral da União, objeto da abordagem exploratória. Os relatórios parlamentares são referenciados junto à bibliografia.

\subsubsection{Peças orçamentárias federais}

As peças orçamentárias autorizam o gasto público brasileiro. A literatura aponta, contudo, os limites à racionalização do orçamento público (Core, 2001; p.26; Mendes, 2008; Peres, 2018; Peres; Santos, 2018). Em outras palavras, e também considerado o caráter autorizativo das peças orçamentárias, é pouco provável que a execução das finanças públicas seja um reflexo exato das peças orçamentárias. De qualquer modo, o estudo de peças orçamentárias federais subsidia, em termos qualitativos, o entendimento sobre a finalidade proposta ao gasto público, central à operacionalização desta pesquisa, e o entendimento sobre as classificações programáticas. Para além de apoiar uma definição sobre "desenvolvimento urbano", quais os recursos financeiros são destinados ao desenvolvimento urbano? 
Em termos orçamentários, a classificação programática, ou programa, significa "o problema a ser resolvido por meio do gasto público". ${ }^{226}$ A classificação programática também significa a associação entre peças orçamentárias e a execução dos recursos orçamentários, ${ }^{227}$ ou seja, entre Plano Plurianual (PPA), Lei de Diretrizes Orçamentárias (LDO), Lei Orçamentária Anual (LOA) e a execução orçamentária. Neste sentido, entender a regulação dos programas federais a partir das peças orçamentárias auxilia a compreensão sobre a finalidade do gasto público, compondo um quadro de referência à pesquisa. ${ }^{228}$

O PPA é a peça orçamentária de caráter estratégico e de médio prazo e, dentre outros, apresenta o detalhamento de objetivos, ações, metas e iniciativas para cada classificação programática. Neste sentido, subsidia a definição do recorte de pesquisa. Mas conferir uma maior precisão ao recorte da pesquisa demanda uma segunda verificação, com atenção às ações de fato promovidas no âmbito de cada programa federal. Neste sentido, e a partir de classificação programática, são justapostos planejamento e execução orçamentária. A justaposição entre peças e execução orçamentárias subsidia a validação de recorte de pesquisa, com atenção às ações efetivadas (com recursos executados) no âmbito de cada programa federal. O refinamento de recorte adotado por esta pesquisa atende à definição de "desenvolvimento urbano", definição já apresentada por presente capítulo.

Para o ano de 2018, o orçamento atualizado da despesa federal é de $R \$ 3,46$ trilhões de reais. ${ }^{229}$ A complexidade apresentada pelas finanças públicas federais demanda aproximações faseadas, estratégia que também contribui à precisão de recorte de pesquisa. ${ }^{230}$ Para o estudo das finanças municipais, por exemplo, o método aqui proposto pode ser menos pertinente, de modo que o universo empírico é mais restrito.

\footnotetext{
226 Segundo Rezende (2006; p.81): "programa: instrumento de organização da ação governamental que visa à concretização dos objetivos pretendidos, sendo mensurado por indicadores estabelecidos no plano plurianual".

227 Segundo Core (2001; p.23), pelo menos desde a edição da portaria no 9, de 28 de janeiro de 1974, a classificação programática articula planejamento e execução orçamentária no país.

228 Interessante mencionar, as peças orçamentárias federais também podem apresentar diretrizes às agências financeiras no país.

229 <http://www.portaltransparencia.gov.br/orcamento?ano=2018>, consultado em setembro de 2019.

${ }^{230}$ No caso da presente pesquisa, esta estratégia foi possível por ser coletivamente desenvolvida no âmbito de grupo de pesquisa "Produção do espaço urbano e finanças contemporâneas: o papel do fundo público", coordenado pela professora Luciana de Oliveira Royer, com sede no LABHAB-FAU-USP.
} 
Assim, em associação à análise da execução orçamentária, o estudo das peças orçamentárias estrutura o recorte de pesquisa a partir da avaliação qualitativa de programas, posteriormente validada a nível de ações a partir da execução orçamentária. ${ }^{231}$ Deve estar claro que o recorte de pesquisa é realizado ao nível de programas e o estudo das ações representa uma etapa de validação. A lista de classificações programáticas que compõe recorte de pesquisa, com atenção à execução do Orçamento Geral da União, é apresentada em anexo (Quadro Anexo 2; Quadro Anexo 3).

As peças orçamentárias, aprovadas em formato de lei, estão disponíveis em portais eletrônicos do governo federal, de acesso público. Os portais eletrônicos consultados estão apresentados em bibliografia.

\subsubsection{Abordagem exploratória e estudo de caso}

No que se refere aos dados primários de abordagem exploratória e estudo de caso, serão avaliados a execução do Orçamento Geral da União (2000-2016) e a receita realizada de município de São Paulo (2003-2016), respectivamente. Os dados primários são obtidos a partir do portal eletrônico do governo federal e da prefeitura do município de São Paulo, por vezes por meio da Lei de Acesso à Informação (LAI). As fontes de dados primários são apresentadas junto à bibliografia. Relativo à abordagem exploratória e estudo de caso, os valores financeiros apresentados são corrigidos de acordo com o Índice Nacional de Preços ao Consumidor Amplo (IPCA-IBGE), e adotam o ano de 2016 como referência.

\footnotetext{
${ }^{231}$ Há recortes de pesquisa determinados a partir da classificação funcional da despesa. Essa opção confere maior agilidade à pesquisa, ancora-se em normativa e sistemas federais, mas também pode significar menor precisão em termos de avaliação. Tal imprecisão pode remontar à classificação da despesa pelos municípios. A classificação funcional é normatizada por esfera federal, mas o município pode classificar a despesa com mobilidade urbana na função "urbanismo". O município de São Paulo, por exemplo, classifica a despesa com mobilidade urbana na função "transporte". Agradecemos a Fabio Pereira pelos comentários.

Em linhas gerais, o recorte de pesquisa deve ser debatido a partir do universo empírico da pesquisa, horizonte normativo e objetivos adotados por pesquisa, e as escolhas de pesquisa devem ser esclarecidas ao leitor. Em geral e em termos de processo orçamentário, para além da confeç̧ão das peças orçamentárias, a criação de novos programas pode ser proposta pelo executivo por meio de projetos de lei, e a inclusão, alteração ou exclusão de ações orçamentárias pode dar-se por intermédio da LOA ou créditos adicionais (Garson, 2018; p.192).
} 


\subsubsection{Abordagem exploratória}

Para compreender o financiamento fiscal do desenvolvimento urbano não é suficiente atentar-se às peças orçamentárias, sendo a execução orçamentária a evidência empírica sobre a articulação material real entre finanças públicas, atuação estatal e urbano. A execução do Orçamento Geral da União é a base empírica da abordagem exploratória.

A abordagem exploratória orienta-se pelo estudo da execução do Orçamento Geral da União para o período de 2000 a 2016, de forma a abarcar o principal orçamento público do país $^{232}$ e recorte temporal suficiente ao entendimento de sua histórica recente. Para o período de 2000 a 2016, o banco de dados da execução do Orçamento Geral da União é composto por mais de 530.000 dotações orçamentárias. Com atenção à definição de desenvolvimento urbano, o recorte de pesquisa abarca 50.710 rubricas orçamentárias. ${ }^{233}$ Desse modo, a melhor apreensão de evidências empíricas demanda construção de síntese gráfica quantitativa, por meio de tabelas, gráficos e imagens, por exemplo. O acesso ao banco de dados referente à execução de Orçamento Geral da União dá-se em julho de 2017, pelo portal eletrônico do Sistema Integrado do Planejamento e Orçamento, então sob a gestão do Ministério do Planejamento, Desenvolvimento e Gestão do governo federal.

\begin{tabular}{ll}
\hline $\begin{array}{l}\text { Recorte de pesquisa } \\
\text { Financiamento fiscal do desenvolvimento urbano brasileiro e a execução do Orçamento Geral da União }\end{array}$ \\
\hline $\begin{array}{l}\text { Quantidade de programas selecionados } \\
\text { (sem uniformizações) }\end{array}$ & 69 \\
$\begin{array}{l}\text { Quantidade de ações selecionadas } \\
\text { (uniformização por código) }\end{array}$ & 909 \\
$\begin{array}{l}\text { Quantidade de rubricas selecionadas } \\
\text { Valor total Empenhado }\end{array}$ & 50.710 (9\% banco dados primários) \\
Valor total Liquidado & $\mathrm{R} \$ 352.921 .324 .087$ \\
Valor total Pago & $\mathrm{R} \$ 204.383 .935 .242$ \\
\hline
\end{tabular}

Quadro 2.1: Financiamento do desenvolvimento urbano brasileiro: recorte de pesquisa a partir de banco de dados da execução do Orçamento Geral da União (2000-2016). Ano referência valores: 2016. Elaboração nossa.

${ }^{232}$ A União é o ente federado concentrador de recursos públicos (MacDowell, 2007), mesmo após a repartição constitucional obrigatória (Afonso, 2017).

${ }^{233}$ A complexidade apresentada por execução orçamentária demanda reflexão sobre a gestão desses dados, orientada pela coleta, limpeza (eliminação de ruídos), análise e sociabilização dos resultados. 
A avaliação da execução orçamentária demanda considerar o planejamento e execução orçamentária, mas também as etapas desta, ${ }^{234} \mathrm{com}$ destaque ao empenho, liquidação e pagamento de recursos orçamentários. ${ }^{235}$ Deve ficar claro, no entanto, que a pergunta do pesquisador deve ser ajustada para cada etapa da execução orçamentária. ${ }^{236}$

(i) Empenho: é uma "reserva" de recursos para determinada rubrica orçamentária frente às demais dotações do orçamento (Garson, 2018; p.169). O empenho também pode iluminar questões relativas ao conflito distributivo, já que demonstra o sucesso de determinada dotação orçamentária frente à disputa por recursos financeiros, que são limitados, no âmbito de uma administração.

(ii) Liquidação: atende o direito de contratado em receber seu pagamento, consistindo na verificação de credor por parte da administração pública. Se o empenho é um primeiro compromisso, a liquidação está lastreada na prestação de determinado serviço, ou conclusão total ou parcial de determinado contrato ou obra urbana, por exemplo.

234 Para avaliação a respeito das etapas de execução orçamentária, ou estágios da despesa, esta dissertação beneficia-se do debate apresentado por Peres (2018); Peres e Santos (2018); Mendes (2008); palestra ministrada por Fabio Pereira dos Santos na Residência em Arquitetura e Urbanismo 2015-2016 da FAU-USP, além de debates no âmbito do grupo de pesquisa "Produção do espaço urbano e finanças contemporâneas: o papel do fundo público".

235 Segundo a Lei Federal № 4.320 de 1964 :

“Art. 58. O empenho de despesa é o ato emanado de autoridade competente que cria para o Estado obrigação de pagamento pendente ou não de implemento de condição. [...] Art. 63. A liquidação da despesa consiste na verificação do direito adquirido pelo credor tendo por base os títulos e documentos comprobatórios do respectivo crédito. [...] Art. 64. A ordem de pagamento é o despacho exarado por autoridade competente, determinando que a despesa seja paga".

236 Core (2011; p.8) apresenta reflexão convergente: "No tocante à despesa (pública), as classificações, basicamente, respondem as principais indagações que habitualmente surgem quando o assunto é gasto orçamentário. A cada uma dessas indagações, corresponde um tipo de classificação. Ou seja: quando a pergunta é "para que" serão gastos os recursos alocados, a resposta será encontrada na classificação programática ou, mais adequadamente, de acordo com a portaria no 42/99, na estrutura programática; "em que" serão gastos os recursos, a resposta consta da classificação funcional; "o que" será adquirido ou "o que" será pago, na classificação por elemento de despesa; "quem" é o responsável pela programação a ser realizada, a resposta é encontrada na classificação institucional (órgão e unidade orçamentária); "qual o efeito econômico da realização da despesa", na classificação por categoria econômica; e "qual a origem dos recursos", na classificação por fonte de recursos". Core (2011) também explicita os objetivos por trás das categorias de classificação da despesa pública, elementos da reforma gerencial do planejamento e orçamento no Brasil durante a década de 1990 e início da década de 2000. 
(iii) Pagamento: é a etapa final da execução orçamentária, efetuada pela tesouraria ou instituição bancária após a liquidação de recursos. O empenho de recursos é um primeiro compromisso da administração pública, contudo, não é possível deduzir que os recursos empenhados serão liquidados ou pagos.

Garson (2018; pp.168-9) debate os estágios de despesa. Para a autora, a apuração dos gastos públicos para posterior avaliação dos resultados deveria considerar a liquidação dos recursos, considerando ainda que a liquidação pode remontar ao empenho realizado em exercícios fiscais anteriores (Garson, 2018; p.169). Essa é a estratégia adotada pela pesquisa. Isso pois tratamos de debater a atuação estatal sobre o espaço e, neste sentido, é central a atenção à conclusão total ou parcial de determinado serviço ou obra.

Cabe lembrar, é a liquidação a etapa amparada nas recomendações da Lei de Responsabilidade Fiscal. Ainda, utilizar os valores pagos tende a subestimar o gasto público, uma vez que é necessário o estudo associado dos "restos a pagar". Contudo, os "restos a pagar" são executados de modo extraorçamentário e a partir de registros por meio do Cadastro Nacional da Pessoa Jurídica (CNPJ). ${ }^{237}$

A administração pública pode deixar de pagar despesas empenhadas e liquidadas, as quais são realocadas no orçamento do ano seguinte (próximo exercício fiscal) sob a forma de "restos a pagar". Segundo Mendes (2008; p.16-8), isso acontece por (i) simular o atendimento à Lei de Responsabilidade Fiscal a partir do empenho de recursos, que determina a execução de despesas diante da realização de receita prevista, mas sem de fato efetuar a liquidação ou pagamento; (ii) elevar o superavit primário, calculado a partir dos recursos na conta do Tesouro, e não exatamente a partir do comprometimento dos recursos (empenho e liquidação); (iii) barganha entre executivo e parlamentares, que deverão seguir negociando frente à estratégia do restos a pagar. Segundo Mendes, esse fenômeno é conhecido como contingenciamento, ou "limitação de empenho e movimentação financeira", expressivo no início do ano orçamentário, com a execução de recursos realizada de acordo com a efetivação de receita. Para o orçamento

\footnotetext{
${ }^{237}$ Agradecemos aos comentários da professora doutora Ursula Dias Peres.
} 
de 2006, Mendes demonstra que o contingenciamento sobre os investimentos públicos é bastante expressivo, dos quais apenas $33 \%$ dos valores previstos foram empenhados. ${ }^{238}$

Em associação, a avaliação sobre a execução orçamentária demanda perspectiva multicausal, já que agência e estrutura conformam a execução dos recursos orçamentários no Brasil. ${ }^{239}$ A questão de pesquisa, no entanto, refere-se ao desenvolvimento urbano brasileiro. Sendo o desenvolvimento urbano o foco argumentativo da dissertação, as premissas adotadas para a avaliação sobre as etapas de execução orçamentária são:

(i) A articulação estatal frente ao desenvolvimento urbano brasileiro: o empenho de recursos não representa o efetivo financiamento das infraestruturas urbana e habitacional, mas um primeiro compromisso assumido pela administração pública; ${ }^{240}$

(ii) A dimensão processual do financiamento fiscal do desenvolvimento urbano brasileiro: a relação entre liquidação e empenho ilumina a não-linearidade do processo orçamentário, possibilitando o debate sobre limites e possibilidades ao efetivo financiamento das infraestruturas urbana e habitacional no país;

\footnotetext{
${ }^{238}$ A relação pagamento / empenho para os grupos de natureza de despesa federal deu-se então da seguinte maneira: investimentos (33\%); inversões financeiras (74\%); outras despesas correntes (95\%); pessoal e encargos sociais (99\%); juros e encargos da dívida (100\%); amortização e refinanciamento da dívida (100\%) (Mendes, 2008; p.18). Garson (2018; p.170) apresenta avaliação convergente a respeito da não liquidação de empenhos, com destaque aos recursos alocados em investimentos, e acrescenta que os empenhos não liquidados podem vir a ser cancelados.

239 Peres (2018) debate as disputas em torno das finanças públicas, com atenção à regulação de orçamento, à estrutura hierárquica da administração pública e à complexificação do processo orçamentário frente ao incrementalismo e períodos de escassez de recursos financeiros, por exemplo. A partir de Peres (2018), é possível assumir que a política (ou agência), para além das estruturas econômicas e institucionais, também confere relevo à administração dos recursos fiscais no Brasil, o que implica novas camadas à compreensão das etapas de execução orçamentária.

${ }^{240}$ A acepção da locução articulação estatal implica reconhecer sua expressão social. Para esta dissertação, a semântica de articulação estatal equivale àquela de atuação estatal. No entanto, cabe distinguir que o signo articulação pode melhor exprimir, mesmo que intuitivamente, o significante de relações e processos em torno de; a partir de; com vistas a; em meio a a administração pública. Desse modo, opta-se aqui, em específico, pela utilização do termo articulação, e a associação deste à ideia de compromisso. Há de ficar claro, contudo, que a agência não é a inquietação central desta pesquisa, apesar de sua reconhecida relevância à compreensão dos fenômenos aqui referenciados.
} 
(iii) O efetivo desenvolvimento urbano promovido a partir das finanças públicas: a liquidação de recursos financeiros está lastreada em base material, assim, a liquidação é a proxy de produto urbano a partir dos recursos orçamentários. ${ }^{241}$

O presente estudo confere centralidade à abordagem exploratória de execução orçamentária federal. Assume-se que a liquidação de recursos financeiros representa a intervenção material nas cidades brasileiras, ainda que o pagamento não seja realizado imediatamente após a liquidação desses recursos. De modo geral, a partir da execução orçamentária é possível uma avaliação quanti-qualitativa sobre o financiamento fiscal do desenvolvimento urbano brasileiro.

\subsubsection{Estudo de caso}

O debate sobre o financiamento fiscal do desenvolvimento urbano demanda um esforço multiescalar devido ao modelo federativo tripartite da organização socioterritorial do Brasil. Se o desenvolvimento urbano é competência das diversas esferas do poder executivo, a pesquisa compreenderá articulação entre esferas federal, estadual e municipal.

O estudo de caso analítico ${ }^{242}$ é a receita realizada da prefeitura do município de São Paulo, para o período de 2003 a 2016. O recorte temporal relaciona-se com a disponibilidade de dados primários. A opção por estudo de caso analítico justifica-se por:

(i) Consolidação de atuação estatal frente ao urbano: Contribuir qualitativamente ao debate sobre a consolidação e articulação de atuação estatal frente ao urbano, nos termos discutidos anteriormente por este capítulo;

(ii) Relações entre urbano, atuação estatal e riqueza pública: Contribuir quantiqualitativamente ao desvelamento de relações entre urbano, atuação estatal e riqueza pública a partir das finanças da capital paulista.

\footnotetext{
241 "Se foram empenhados recursos para a compra de medicamentos novos para combate a uma doença, mas nada foi liquidado, ou seja, os medicamentos não foram entregues, não há como esperar qualquer melhoria na qualidade de vida dos pacientes" (Garson, 2018; p.170).

242 "Estudo de caso analítico": entendimento conforme Almeida (2016).
} 
A concentração de riqueza associada ao município de São Paulo ilustra sua condição de "estudo de caso único". 243 Descartada a generalização de avaliações específicas, a condição de outliner do município de São Paulo ainda se demonstra pertinente ao debate sobre urbano, atuação estatal e finanças públicas, iluminando tendências apresentadas às cidades brasileiras, conforme apresentado pela seção 3.3 do presente trabalho.

\subsubsection{Apontamentos metodológicos sobre o tratamento das finanças públicas}

Sobre o estudo da relação entre planejamento e execução orçamentária, interessa a articulação a partir da classificação programática e empenho de recursos financeiros, de modo a debater a relação entre plano ou previsão e um primeiro compromisso orçamentário.

Em termos de execução orçamentária, o estudo das ações ou iniciativas é fundamental. A prática demonstra que as classificações programáticas podem ser atualizadas, também de acordo com as peças orçamentárias, mas isso não implica necessária ruptura com as ações ou iniciativas já em curso. Uma urbanização de assentamento precário pode ser conduzida durante anos, o que demanda a execução de recursos financeiros durante todo esse período: seja por meio do programa " $A$ ", seja por meio do programa "B", o estudo das ações orçamentárias ainda expressará a "urbanização de assentamento precário Y". 244

Para estudos comparados entre entes federados a alternativa é a execução orçamentária. A elaboração das peças orçamentárias é obrigatória para todos os entes federados, mas não há normatização sobre "como" deveriam ser essas peças, o que torna dificultosa qualquer comparação. Em termos de orçamento público, a principal regulação é a Lei Federal № 4.320 de 1964, ${ }^{245}$ ainda que caiba reconhecer a importância das reformas administrativas da década de 1990, debate já referenciado pelo capítulo 1 desta dissertação.

\footnotetext{
${ }^{243}$ Não é possivel uma associação direta entre o município de São Paulo e os demais municípios brasileiros. A literatura chega mesmo a apontar o "porte estadual" de orçamento de município de São Paulo (Peres, 2018; p.122). Em associação ao arranjo tributário brasileiro, o setor de serviços, o mercado imobiliário e o patrimônio predial e territorial urbano paulistano, por exemplo, reforçam a distinção entre a capital paulista e demais municípios.

${ }^{244}$ Ver o debate de Peres e Santos (2018) sobre o incrementalismo orçamentário.

${ }^{245}$ Garson (2018; p.165) apresenta, por exemplo, quadro sobre a relevância da Lei Federal № 4.320 de 1964 para a apuração do gasto público no Brasil.
} 
Em termos de método, o estudo sobre o financiamento do desenvolvimento urbano a partir das finanças públicas contribui à construção de entendimentos interrelacionais entre diferentes faces da atuação estatal, a exemplo do entendimento articulado entre política habitacional, de saneamento básico e mobilidade urbana. A presente dissertação dedica esforços nessa direção. 


\section{Financiamento fiscal do desenvolvimento urbano}

A década de 1990 é marcada pela construção de um novo regime fiscal brasileiro, ampliação do controle das contas públicas e por uma política fiscal qualificada como austera. ${ }^{246}$ O campo do planejamento urbano e regional aponta transformações nas cidades brasileiras durante o início do século XXI, em parte impulsionadas pelo bom desempenho macroeconômico pós-crise cambial de 1999 e pelas menores taxas de juros, mas em grande medida orientadas pela atuação estatal. O Programa de Aceleração do Crescimento (PAC) e o Programa Minha Casa, Minha Vida (PMCMV), e os temas correlatos, a exemplo dos Jogos Olímpicos, Mundial de Futebol e Manifestações de Junho de 2013, assumem destaque no debate público. Por um lado, reconhece-se a permanência da centralidade dos fundos parafiscais, FGTS e SBPE, para o financiamento dessas transformações. Por outro lado, são apontadas inovações e uma ampliação da alocação de recursos fiscais, recursos não-onerosos aplicados "a fundo perdido", em relação ao financiamento do urbano. ${ }^{247}$ Sobre isso, nosso estudo empírico demonstra que entre 2000 e 2016 são empenhados $\mathrm{R} \$ 352$ bilhões de reais e liquidados $\mathrm{R} \$ 204$ bilhões de reais oriundos do Orçamento Geral da União com vistas ao financiamento do desenvolvimento urbano brasileiro (Quadro 3.1; Gráfico 3.1) (ano referência 2016). ${ }^{248}$ Adiante avaliação sobre o financiamento fiscal do desenvolvimento urbano brasileiro, especificamente sobre a execução do Orçamento Geral da União para o período de 2000 a 2016.

No detalhe, e em termos de valores empenhados, entre os anos de 2000 e 2006 os valores anuais oscilam de R\$7 bilhões em 2004 até $R \$ 12$ bilhões em 2001. A exceção no período é o ano de 2002, com um montante equivalente de $\mathrm{R} \$ 28$ bilhões empenhados, melhor compreendido pela próxima seção do presente trabalho. Como particularidade desse período,

\footnotetext{
${ }^{246}$ As políticas habitacionais e de saneamento e meio ambiente financiadas por recursos não-onerosos federais contam com histórico de contingenciamento que se estende da década de 1980 a 2002, com breve ampliação dos gastos verificada entre 1995 e 1998. Essa breve ampliação dos gastos é interrompida por conta de restrições fiscais decorrentes da crise cambial dos anos 1990 e das cláusulas de superávit primário negociadas com o Fundo Monetário Internacional. Este fato seria evidência da subordinação das políticas sociais em geral, e daquelas em particular, à política macroeconômica restritiva (Ipea, 2009; p.246; 250). Este estudo do IPEA apresenta ampla avaliação sobre o financiamento de políticas públicas durante os governos de Fernando Henrique Cardoso.

${ }^{247}$ Financiamento do urbano; financiamento do desenvolvimento urbano; financiamento fiscal do desenvolvimento urbano aqui adotados enquanto equivalentes. Caso o texto não se refira ao financiamento fiscal, será especificado. 248 Os gráficos, imagens e tabelas elaborados por nós adotam como ano referência 2016.
} 
destaca-se que o total de recursos empenhados é também liquidado, o que não implica correspondência direta entre empenho e liquidação, mas indica linearidade na administração dos recursos orçamentários. Nesse período e em termos absolutos quantitativos, não há forte inflexão em termos de alocação de recursos fiscais federais e o financiamento do desenvolvimento urbano, apesar da criação do Ministério das Cidades em 2003 e do Fundo Nacional de Habitação de Interesse Social em 2005, por exemplo. 249

\begin{tabular}{|c|c|c|}
\hline \multicolumn{3}{|c|}{$\begin{array}{l}\text { Execução do Orçamento Geral da União e o Financiamento fiscal do desenvolvimento urbano: } \\
\text { Empenho e liquidação entre } 2000 \text { e } 2016\end{array}$} \\
\hline Ano & Empenhado & Liquidado \\
\hline 2000 & $R \$ 10.688,46$ & $R \$ 10.688,46$ \\
\hline 2001 & $\mathrm{R} \$ 12.733,54$ & $\mathrm{R} \$ 12.733,54$ \\
\hline 2002 & $R \$ 28.635,80$ & $\mathrm{R} \$ 28.635,80$ \\
\hline 2003 & $\mathrm{R} \$ 11.242,44$ & $\mathrm{R} \$ 11.242,21$ \\
\hline 2004 & $\mathrm{R} \$ 7.032,73$ & $\mathrm{R} \$ 7.032,73$ \\
\hline 2005 & $R \$ 9.273,76$ & $R \$ 9.273,76$ \\
\hline 2006 & $\mathrm{R} \$ 10.007,17$ & $\mathrm{R} \$ 10.007,17$ \\
\hline 2007 & $R \$ 27.843,25$ & $R \$ 13.207,87$ \\
\hline 2008 & $\mathrm{R} \$ 16.380,10$ & $R \$ 3.934,25$ \\
\hline 2009 & $R \$ 26.587,45$ & $\mathrm{R} \$ 8.456,18$ \\
\hline 2010 & $R \$ 26.932,18$ & $R \$ 8.360,62$ \\
\hline 2011 & $R \$ 29.742,34$ & $R \$ 4.288,08$ \\
\hline 2012 & $R \$ 26.042,19$ & $R \$ 7.163,66$ \\
\hline 2013 & $R \$ 29.252,07$ & $\mathrm{R} \$ 11.617,06$ \\
\hline 2014 & $\mathrm{R} \$ 41.539,39$ & $\mathrm{R} \$ 28.323,50$ \\
\hline 2015 & $R \$ 25.606,20$ & $R \$ 19.738,95$ \\
\hline 2016 & $\mathrm{R} \$ 13.382,26$ & $\mathrm{R} \$ 9.680,10$ \\
\hline
\end{tabular}

Quadro 3.1: Execução do Orçamento Geral da União e o financiamento do desenvolvimento urbano brasileiro: empenho e liquidação entre 2000 e 2016. Valores em milhões. Ano referência de valores: 2016. Fonte: Sistema Integrado de Planejamento e Orçamento, Ministério do Planejamento, Desenvolvimento e Gestão do Governo Federal. Elaboração nossa.

249 Lei № 11.124, de 16 de junho de 2005: Dispõe sobre o Sistema Nacional de Habitação de Interesse Social SNHIS, cria o Fundo Nacional de Habitação de Interesse Social - FNHIS e institui o Conselho Gestor do FNHIS. 


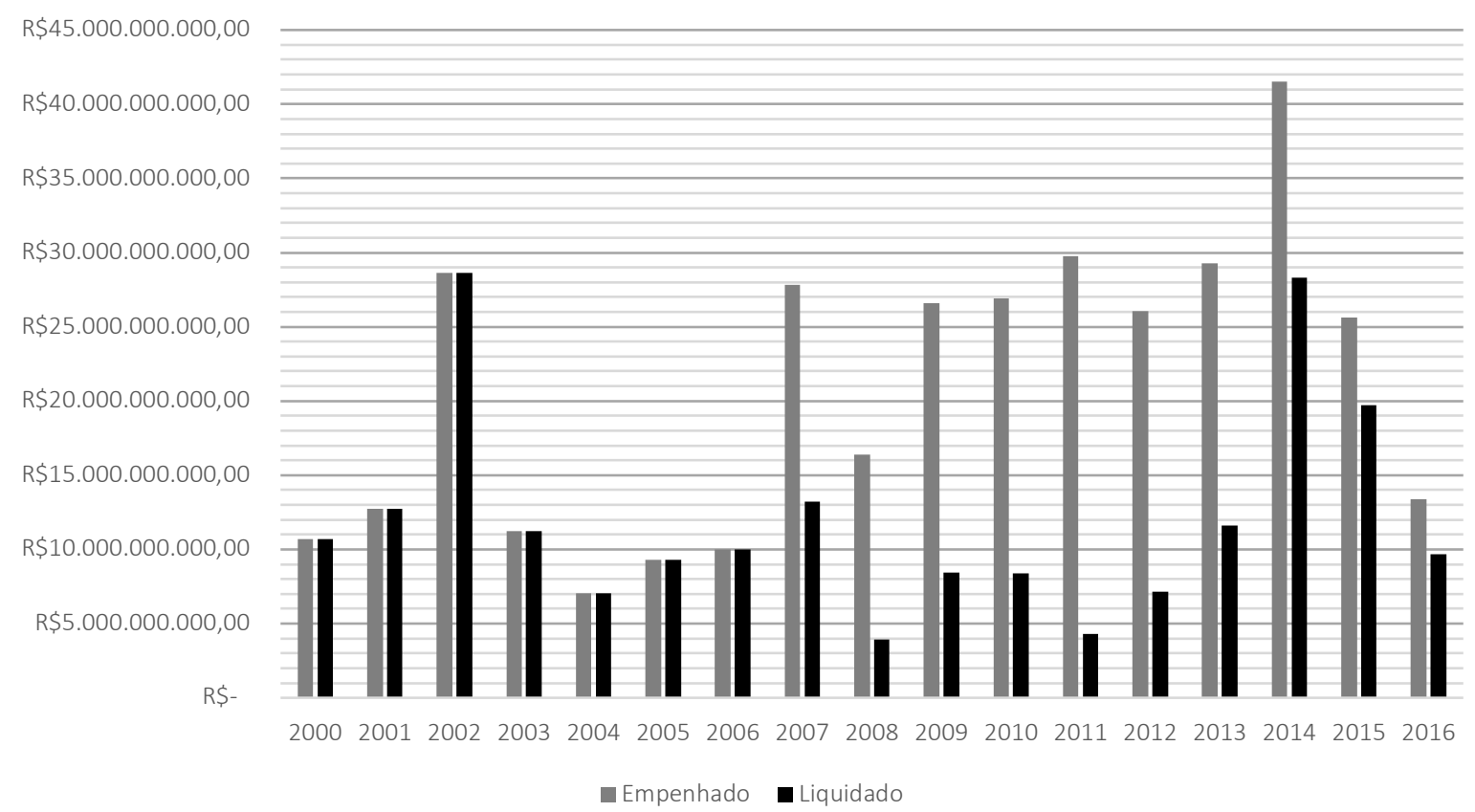

Gráfico 3.1: Execução do Orçamento Geral da União e o financiamento do desenvolvimento urbano brasileiro: empenho e liquidação entre 2000 e 2016. Ano referência de valores: 2016. Fonte: Sistema Integrado de Planejamento e Orçamento, Ministério do Planejamento, Desenvolvimento e Gestão do Governo Federal. Elaboração nossa.

Em termos de política fiscal, o debate sobre crescimento econômico frequentemente demonstra-se associado à ideia de ótimos resultados primários, ideia que ganha espaço no governo federal em 2004 e parece associar-se à redução do financiamento fiscal do desenvolvimento urbano nesse ano. Entre 2004 e 2006 os montantes totais anuais, empenho ou liquidação, são inferiores aos montantes anuais apresentados entre 2000 e 2003, inclusive. Entre 2003 e 2004 há avaliações positivas a respeito do cenário macroeconômico, mas também ceticismos em relação à progressividade de atuação estatal, frente à capacidade social em alinhar crescimento econômico e pobreza, o que delineia o controle sobre o gasto federal no âmbito do planejamento orçamentário. ${ }^{250}$ Relacionado a isso, diante do projeto de PPA 20042007 federal, há o reconhecimento parlamentar sobre a relevância de atuação estatal para a condução do desenvolvimento nacional, mas essa atuação deveria dar-se em setores

${ }^{250}$ Cf. Congresso Nacional, 2003; p.10.

A interface entre Executivo, Parlamento e orçamento público ainda se relaciona às emendas parlamentares, mas estas não são tratadas pelo presente estudo. 
específicos, tidos como pouco atrativos ao setor privado. ${ }^{251}$ Frente à desaceleração econômica e ao aumento da taxa de juros, a proposta de endurecimento do ajuste fiscal federal encontra resistências intragovernamentais em 2005. ${ }^{252}$ As relações estabelecidas entre execução e controle do gasto federal, entre desempenho econômico nacional, expectativa dos agentes privados entre 2003 e 2006 e resistências intragovernamentais à ampliação de ajuste fiscal em 2005, iluminam a contração dos gastos federais em desenvolvimento urbano em 2004 (R\$7 bi), mas também o subsequente crescimento incremental desses gastos em 2005 (R\$9 bi) e 2006 ( $\mathrm{R} \$ 10 \mathrm{bi})$.

A nova composição do Ministério da Fazenda em 2006 indica o redirecionamento da política fiscal federal, com o resgate de mecanismos de intervenção estatal na economia, tal como debatido pelo capítulo 1. Entre 2004 e 2008 para o comércio mundial, entre 2006 e 2010 para a economia brasileira, ${ }^{253}$ o bom desempenho de economia e a ampliação da arrecadação de receitas associa-se ao empenho de $\mathrm{R} \$ 27$ bilhões em 2007 e a liquidação de $\mathrm{R} \$ 13$ bilhões em prol do desenvolvimento urbano. Diante do projeto do PPA 2008-2011 apresentado pelo Executivo em 2007, o Parlamento já identifica a proposta de desenvolvimento de longo prazo e aceleração do crescimento econômico com inclusão social a partir do orçamento e

\footnotetext{
251 Para o Parlamento em 2004, a relevância de atuação estatal para desenvolvimento nacional também está associada às assimetrias de informação e externalidades prejudiciais ao "bom desempenho de leis de mercado". Segundo documento consultado, a atuação estatal seria fundamental para as atividades e investimentos em áreas específicas, tal como energia (enquanto setor estratégico de economia) e mobilidade urbana (a exemplo de construção de metrô, considerada enquanto "pouco atrativa ao setor privado") (Congresso Nacional, 2004, p.11). Em paralelo, em 2004 é promulgada a Lei № 11.079, de 30 de dezembro, que institui normas gerais para licitação e contratação de parceria público- privada no âmbito da administração pública.

${ }^{252}$ Vale lembrar, em 2005 o regime fiscal brasileiro incorpora a possibilidade de excluir os gastos com investimentos da base do cálculo do resultado primário. Além disso, em maio de 2005 o Mensalão é divulgado por reportagem de Revista Veja, em julho de 2005 o ministro das cidades é indicado pelo PP.

253 Para Serrano e Summa (2018) a economia brasileira cresceu entre 2004 e 2010. Carneiro (2017) apresenta avaliação convergente, mas para o período de 2003 a 2010.
} 
investimentos públicos. ${ }^{254}$ O cenário macroeconômico em 2007 é positivo, e apresenta "bases sólidas", tal como sugere o Parlamento. ${ }^{255}$

No bojo do processo orçamentário, o executivo federal confere centralidade às iniciativas PAC, que apesar de prioritárias pouco são esclarecidas pelo planejamento ou execução orçamentária. ${ }^{256}$ A partir de 2007, e ao menos até 2013, se destaca a dificuldade em liquidar os recursos fiscais empenhados em desenvolvimento urbano, com explicações diversas sobre esse fenômeno. ${ }^{257}$ Assim, mesmo que recursos do OGU sejam destinados ao desenvolvimento urbano, a grande parte desses recursos não é liquidada, ou seja, não encontra lastro material nas cidades brasileiras. Em 2008, mesmo com o empenho de $\mathrm{R} \$ 16$ bilhões, menos de R\$4 bilhões são liquidados neste ano, o ano com mais baixa liquidação de recursos do OGU em prol do desenvolvimento urbano entre 2000 e 2016. Entre 2007 e 2013 foram empenhados mais de $\mathrm{R} \$ 180$ bilhões e apenas $\mathrm{R} \$ 57$ bilhões foram liquidados, ou seja, cerca de $31 \%$ dos recursos empenhados foram liquidados.

\footnotetext{
${ }^{254}$ Relativo ao tema, em 2007 é promulgada Lei № 11.445, de 5 de janeiro: Estabelece diretrizes nacionais para o saneamento básico; altera as Leis nos 6.766, de 19 de dezembro de 1979, 8.036, de 11 de maio de 1990, 8.666, de 21 de junho de 1993, 8.987, de 13 de fevereiro de 1995; revoga a Lei no 6.528, de 11 de maio de 1978; e dá outras providências.

A Lei № 11.445 é alterada em 2018 pela Medida Provisória № 844, de 6 de julho: Atualiza o marco legal do saneamento básico e altera a Lei no 9.984, de 17 de julho de 2000, para atribuir à Agência Nacional de Águas competência para editar normas de referência nacionais sobre o serviço de saneamento, a Lei no 10.768, de 19 de novembro de 2003, para alterar as atribuições do cargo de Especialista em Recursos Hídricos, e a Lei no 11.445, de 5 de janeiro de 2007, para aprimorar as condições estruturais do saneamento básico no País.

${ }^{255}$ Sobre o momento brasileiro: Em outubro de 2007 o Brasil é apresentado como sede do Mundial de Futebol de 2014. Em junho de 2008 o Rio de Janeiro é finalista no processo de escolha da sede dos Jogos Olímpicos de 2016. O Rio de Janeiro é definido como sede olímpia em outubro de 2009.

256 O Programa de Aceleração do Crescimento (PAC) é criado por meio do Decreto № 6.025 de 2007 . Segundo documento elaborado pelo Congresso Nacional em 2007, ressalta-se que o Órgão Central de Planejamento e Orçamento Federal deveria processar o cadastramento de empreendimentos, autorização de empenho, monitoramento de execução física, orçamentária e financeira de contratos e convênios promovidos pelo programa. Ainda, o projeto do PPA 2008-2011 determinou que as ações do PAC teriam tratamento diferenciado. A descrição das ações que integram o PAC deveria ser dotada de informações complementares aos projetos de leis orçamentárias e conforme definido em lei específica, contemplando a relação por órgão e unidade. À época, critica-se que o caráter prioritário conferido ao PAC no âmbito do PPA exigiria definição mais clara das ações que integram o programa (Congresso Nacional, 2007; p.5). O que de fato compôs a carteira de investimentos do PAC está em avaliação. Mesmo a partir dos dados orçamentários, nosso objeto de pesquisa, é dificultosa a enumeração das iniciativas financiadas por esse programa.

${ }^{257}$ Cabe situar que a relação empenho / liquidação encontra baixa relação com os ciclos eleitorais.
} 
Em setembro de 2008 há a falência do banco Lehman Brothers, um dos estopins da crise econômica internacional, fenômeno que afeta o crescimento econômico brasileiro em 2009, mas não os investimentos públicos federais, ou o financiamento do desenvolvimento urbano, que crescem entre 2008 e 2010. Neste momento, nos anos de 2009 e 2010, a análise dos anexos de meta fiscal da LDO demonstra a dedução dos investimentos e despesas PAC de resultado primário federal. Além disso, as Medidas Provisórias 496 de 2010 e 487 de 2010 facilitam o acesso ao crédito por governos subnacionais com vistas ao financiamento de obras. Sobre esse momento, há quem sinalize o papel dos investimentos estimulados por esfera federal para a manutenção de estabilidade econômica nacional frente à crise internacional. ${ }^{258}$ Nos anos de 2009 e 2010 são empenhados R\$26 bilhões e liquidados R\$8 bilhões, o que em parte sinaliza o esforço estatal no direcionamento de recursos fiscais ao desenvolvimento urbano, mas também as dificuldades em materializar tais investimentos.

No âmbito do planejamento orçamentário 2012-2015 realizado em 2011, as avaliações sobre o cenário macroeconômico já não demonstram a segurança do momento anterior, e o Congresso Nacional chega a revisar a projeção de crescimento econômico nacional em 2012 apresentada pelo Executivo. De qualquer modo, para o quadriênio em questão assume-se a tendência de crescimento econômico com inclusão social, orientada pela ampliação dos investimentos e atenção às metas fiscais, o que sinaliza a busca por alinhar redistribuição de renda e riqueza internas à inserção econômica internacional. ${ }^{259}$ O projeto do PPA 2012-2015

\footnotetext{
258 Ver capítulo 1.

259 Interessante notar que, diante de instabilidade econômica internacional, o ativismo fiscal e a manutenção de equilíbrio das contas públicas aparecem enquanto estratégias à manutenção de crescimento econômico, alinhamento que aponta para o debate sobre o custeio da administração pública. Os trechos adiante sintetizam esse debate:

O projeto do PPA 2012-2015 adota como base a tendência de crescimento econômico com inclusão social, redução de vulnerabilidade externa e "estabelecimento de metas fiscais". O plano propõe a melhoria da infraestrutura, fortalecimento de mercado interno, manutenção de ambiente macroeconômico estável, consolidação de financiamento de longo prazo, ampliação do investimento, aproveitamento das reservas naturais do pré-sal, dentre outros (Congresso Nacional, 2011; p.2).

A redução de apenas 0,5\% para a previsão de crescimento real do PIB em 2012 se deve à expectativa de reativação de atividade econômica nacional a partir de maior ativismo fiscal, centrado no fortalecimento de investimentos notadamente via PAC -, mas também pela desobstrução de contenção de contenção de crédito e redução de taxa de juros básica SELIC (Congresso Nacional, 2011; p.10). "[...] entendemos que a nova política monetária de redução sustentada da taxa básica de juros SELIC e de remoção dos entraves macroprudenciais à expansão do crédito, associados à retomada dos investimentos públicos, fazem com que o quadro econômico desenhado pelo PPA 2012-2015 seja factível de realização" (Congresso Nacional, 2011; p.13).
} 
defende $26 \%$ dos recursos dos programas temáticos às políticas de infraestrutura. ${ }^{260} \mathrm{O}$ projeto de ampliar os investimentos públicos federais a partir do orçamento público manifesta-se assim no financiamento fiscal do desenvolvimento urbano, o que significa um expressivo crescimento dos montantes liquidados entre 2011 (R\$4 bilhões) e 2014 (R\$ 28 bilhões). Em 2015 o montante é de R\$ 19 bilhões. Em 2011 verificam-se importantes ajustes nos investimentos federais, comportamento geral que não encontra correspondência no financiamento fiscal do desenvolvimento urbano. Vale lembrar, em 2011 é iniciado o PAC 2. Destaca-se ainda a expressiva diminuição do gap entre montantes empenhados e liquidados para os anos de 2014 a 2016, fenômeno orientado pelo modo em que se dá a operação desses recursos, modo debatido mais adiante. Por ora, cabe relacionar que em 2011 é promulgado o Regime Diferenciado de Contratações. ${ }^{261}$ Se entre 2007 e 2013 há a liquidação média de 31\% dos recursos empenhados, entre 2014 e 2016 esse índice médio é de 72\%. Se os valores empenhados quase sempre superam os R\$25 bilhões entre 2007 e 2015, evidenciando os esforços estatais em torno do desenvolvimento urbano, a partir de 2014 uma mudança qualitativa na execução desses recursos é evidente.

O plano reforça que a manutenção de equilíbrio das contas públicas seria fundamental ao crescimento econômico sustentado. Relativo ao tema, e a partir de estimativas em torno das receitas e resultados primários federais, foi prevista a expansão de custeio da administração pública abaixo do crescimento do PIB "[...] denotando a intenção governamental de seguir elevando o investimento público, contido nas despesas discricionárias [...]" (Congresso Nacional, 2011; pp.10-13).

260 É proposta a distribuição dos recursos dos programas temáticos principalmente entre os programas Moradia Digna (R\$389,7 bi), Petróleo e Gás (R\$227,7 bi), Energia Elétrica ( $R \$ 177,2$ bi), Combustíveis ( $R \$ 122,5$ bi) e Transportes (R\$117,1 bi). Destacam-se os recursos destinados ao programa Moradia Digna que "[...] combinados com investimentos em equipamentos sociais e urbanos, deverão aumentar a qualidade de vida nas cidades brasileiras" (Congresso Nacional, 2011; p.7). Relativo a isso e dentre os investimentos voltados ao desenvolvimento e previstos por projeto de PPA 2012-2015, destacam-se a construção de 2 milhões de casas com o Minha Casa, Minha Vida; inclusão de 495 mil domićlios rurais com energia elétrica pelo Luz para Todos; destinação de R\$18 bi a empreendimentos de mobilidade urbana nas grandes cidades e a requalificação de sistemas de mobilidade urbana pactuados para as cidades-sede da Copa do Mundo; regularização da oferta de água para os sistemas de abastecimento de 297 municípios, com destaque para o projeto de integração do rio São Francisco (Congresso Nacional, 2011; p.7-8).

${ }^{261}$ Lei № 12.462, de 4 de agosto de 2011: Institui o Regime Diferenciado de Contratações Públicas - RDC; altera a Lei no 10.683, de 28 de maio de 2003, que dispõe sobre a organização da Presidência da República e dos Ministérios, a legislação da Agência Nacional de Aviação Civil (Anac) e a legislação da Empresa Brasileira de Infraestrutura Aeroportuária (Infraero); cria a Secretaria de Aviação Civil, cargos de Ministro de Estado, cargos em comissão e cargos de Controlador de Tráfego Aéreo; autoriza a contratação de controladores de tráfego aéreo temporários; altera as Leis nos 11.182, de 27 de setembro de 2005, 5.862, de 12 de dezembro de 1972, 8.399, de 7 de janeiro de 1992, 11.526, de 4 de outubro de 2007, 11.458, de 19 de março de 2007, e 12.350, de 20 de dezembro de 2010, e a Medida Provisória no 2.185-35, de 24 de agosto de 2001; e revoga dispositivos da Lei no 9.649, de 27 de maio de 1998. 
Se em 2011 havia incertezas sobre projeções econômicas, entre 2013 e 2015 a crise urbana, econômica e política já está em andamento, ${ }^{262}$ contexto da apresentação do planejamento orçamentário 2016-2019 pelo Executivo ao Parlamento. ${ }^{263}$ A respeito disso, o estudo parlamentar questiona os valores de projeção de crescimento econômico apresentados por executivo para o período de 2016 a 2019, dissonantes das projeções apresentadas por mercado, por exemplo. Para o ano de 2016 foi previsto um crescimento real do PIB de 0,2\%. 2017, 1,7\%; 2018, 2\%; 2019, 2,5\% (Congresso Nacional, 2015; p.16). De qualquer modo, a proposta central de plano demonstra continuidade com os anos anteriores, de crescimento com inclusão social. ${ }^{264}$ Ainda, defende-se que a retomada do crescimento se dê a partir dos investimentos em infraestrutura, ${ }^{265}$ proposta referendada por Parlamento, ${ }^{266}$ sendo os investimentos caracterizados pelo "grande volume de recursos envolvidos para sua

${ }^{262}$ Manifestações de junho de 2013, sinal da crise urbana. Em 2014 o Supremo encerra o julgamento do Mensalão, é iniciada a Operação Lava-Jato. Em 2015 há protestos contra o governo federal, panelaço durante o programa eleitoral do Partido dos Trabalhadores, acolhimento do processo de impedimento da presidente Dilma Rousseff, por exemplo.

263 "O projeto em análise (PPA 2016-2019) foi enviado tempestivamente e tramita junto à Comissão Mista de Planos, Orçamentos Públicos e Fiscalização (CMO), devendo ser apreciado pelo Congresso Nacional até o final da sessão legislativa de 2015 (22 de dezembro) " (Congresso Nacional, 2015, p.1, grifo nosso).

${ }^{264}$ Congresso Nacional, 2015; p.1;5.

265 Segundo o projeto PPA 2016-2019: As políticas de infraestrutura concentram cerca de 21\% dos recursos de programas temáticos, de acordo com o projeto de PPA 2016-2019. As políticas de infraestrutura organizam-se em Infraestrutura Urbana; Petróleo e Gás; Energia Elétrica; Transportes; Combustíveis; outros. Enquanto programas de infraestrutura urbana (de acordo com classificação de projeto de PPA 2016-2019), apresentam-se os programas Moradia Digna, Mobilidade Urbana e Trânsito, Saneamento Básico, Gestão de Riscos e Desastres e Planejamento Urbano, responsáveis por cerca de $\mathrm{R} \$ 750$ bi e representando mais de $50 \%$ dos recursos destinados às políticas de infraestrutura. A respeito das metas de programas de infraestrutura urbana destacam-se: (i) construção de 3 milhões de moradias por meio do programa Minha Casa, Minha Vida; (ii) implantação e/ou requalificação de 1480 $\mathrm{km}$ de sistemas sobre pneus e de $320 \mathrm{~km}$ de sistemas sobre trilhos; (iii) investir R\$2 bi em projetos urbanos estratégicos em territórios de especial interesse, em parceria com a iniciativa privada, para expansão e/ou reabilitação urbana; (iv) ampliação de 54,8 para 57,8 milhões o número de domićlios urbanos abastecidos por rede de distribuição de água ou poço ou nascente com canalização interna; (v) ampliação de 46,8 para 49,6 milhões o número de domicílios urbanos servidos por rede coletora ou fossa séptica para os excretas ou esgotos sanitários (Congresso Nacional, 2015; pp.11-12).

266 O estudo parlamentar reforça o aumento dos investimentos enquanto estratégia ao crescimento econômico e "superação do esgotamento de um modelo de crescimento mais centrado no consumo" (Congresso Nacional, 2015; p.16). Sobre isso, de modo geral, o estudo documental evidencia desconstrução de ceticismo sobre a relevância ou possibilidade de articulação entre crescimento econômico e redução das desigualdades por meio de políticas públicas federais entre 2004 e 2015. Em 2004, nota-se o ceticismo parlamentar a respeito do tema. Em contrapartida, em 2015 reforça-se a importância de retomada de crescimento econômico nacional, entendido enquanto condição à melhoria da qualidade de vida no país, por exemplo. Trata-se de um movimento de curta ou média duração, complexificado frente a instabilidades econômicas, mas que parece ganhar espaço no âmbito do processo de planejamento orçamentário federal durante o período estudado. 
concretização, bem como o longo prazo de maturação dos empreendimentos". Sobre isso, apresenta-se que o PAC continuará a organizar e priorizar os grandes investimentos públicos e de empresas estatais. Ao PAC propõe-se articular o Programa de Investimentos em Logísticas (PIL), organizando a ampliação de concessões e ampliação da oferta de serviços no setor logístico (Congresso Nacional, 2015; p.5). A respeito dos investimentos, o estudo parlamentar chega a apontar as dificuldades em torno da garantia de grandes volumes de recursos orçamentários, longo prazo de maturação, capacidade de planejamento e articulação com a iniciativa privada, além de evidenciar que o PAC e o PIL não encontram correspondência nas peças ou execução orçamentária, o que complexifica qualquer avaliação. ${ }^{267}$ As dificuldades associadas à garantia de recursos orçamentários para a realização de investimentos parece ser acirrada frente ao rebaixamento de rating brasileiro para grau especulativo a partir da avaliação de risco-país, fato em grande medida associado pelo Parlamento à alteração de situação fiscal nacional "[...] representada, por exemplo, pelo envio ao Congresso Nacional da proposta orçamentária para 2016 com um déficit primário da ordem de R\$30 bilhões" (Congresso Nacional, 2015; p.17). Mesmo reconhecendo a potência em torno da promoção de investimentos públicos, o documento elaborado pela CMO apresenta que:

"[...] o emprego da taxa positiva de crescimento real do PIB de 0,20\%, embutida nas projeções para 2016, não é factível de ser obtida, diante das negativas perspectivas econômicas hoje vigentes, cuja reversão depende com destaque do ajuste sustentável das finanças públicas, sem o que não se criará condições para a retomada da confiança dos agentes privados" (Congresso Nacional, 2015; p.17, grifo nosso).

Frente às instabilidades internas e externas e mau desempenho de economia nacional, as restrições orçamentárias sobre despesas discricionárias são acirradas, ${ }^{268}$ com atenção à

\footnotetext{
267 “Nem o PAC nem o PIL, com efeito, são estruturados na forma de programas constantes do PPA, [...] não são identificáveis tanto do ponto de vista qualitativo como quantitativo, isto é, não se pode determinar, no plano plurianual, o que compõe tais programas e quais os seus valores financeiros projetados para o quadriênio 20162019" (Congresso Nacional, 2015; p.16).

268 Desenvolvendo o argumento: Diante de desaceleração econômica, incipiente em 2011 e já bastante clara em 2015, o gasto público busca atender parâmetros de sustentabilidade fiscal, inclusive a partir do planejamento orçamentário. O ajuste fiscal se demonstra a agenda reforçada por parlamento brasileiro e se expressa a partir do exercício de controle do gasto público federal, orientada em grande medida por avaliações em torno de indicadores econômicos nacionais e do resultado primário federal. É o ajuste sustentável das finanças públicas e a confiança de agentes privados os elementos que parecem predominar mais recentemente na prática do controle parlamentar sobre o planejamento orçamentário federal. O ajuste das finanças públicas parece contrapor a própria argumentação favorável à manutenção e ampliação de políticas públicas e do investimento público para a
} 
garantia da confiança privada e com implicações sobre o financiamento do desenvolvimento urbano. No ano de 2016 os valores empenhados e liquidados em prol do desenvolvimento urbano caem substancialmente, atingindo os valores de $\mathrm{R} \$ 13$ bilhões e $\mathrm{R} \$ 9$ bilhões, respectivamente. Após o ano de 2016 a tendência é de uma redução ainda maior a respeito do financiamento fiscal do desenvolvimento urbano nacional, em grande parte sinalizada pela promulgação da Emenda Constitucional 95 em 2016.

Como elemento do debate apresentado, é possível verificar a relevância fiscal do financiamento do desenvolvimento urbano entre 2000 e 2016 (Quadro 3.2; Gráfico 3.2), ou seja, a relação entre os recursos destinados ao desenvolvimento urbano e o total dos valores empenhados e liquidados em acordo com a execução do Orçamento Geral da União. A relevância fiscal do desenvolvimento urbano, com atenção aos valores liquidados, cai entre 2002 (1,78\%) e 2004 (0,39\%), e cresce incrementalmente entre 2004 e 2007 (0,64\%). O índice cai novamente em 2008 (0,2\%), oscila entre 2008 e 2011, e cresce entre 2012 (0,31\%) e 2014 (1,08\%). Cai novamente entre 2014 e 2016 (0,37\%). Em termos relativos, seria possível dizer que 2002 foi o ano de maior relevância fiscal do financiamento do desenvolvimento urbano brasileiro. Em termos absolutos, 2002 é comparável ao ano de 2014. Essa abstração pouco acrescenta ao debate já apresentado, mas apresenta a alta oscilação, também em temos relativos, com que se dá o financiamento fiscal do desenvolvimento urbano. Ora o espaço fiscal do desenvolvimento está restringido a 0,2\% em 2008, ora ocupa 1,78\% em 2002. De modo geral, oscila entre 0,4\% e 0,6\%, e apenas ocasionalmente supera o $1 \%$ da execução do Orçamento Geral da União, e verifica-se baixa correlação entre crescimento econômico e crescimento dos gastos em desenvolvimento urbano.

condução do desenvolvimento nacional com inclusão social. Desse modo, evidenciamos o não rompimento com a ideia de superávit para o período estudado (mesmo quando se acreditava uma política macroeconômica com bases sólidas em 2011), mas destacamos também que, apesar disso, foram construídas condições econômicas e políticas para a ampliação de gastos em políticas sociais. 


\begin{tabular}{lll}
\hline \multicolumn{3}{l}{$\begin{array}{l}\text { Relevância fiscal do desenvolvimento urbano: relação entre financiamento desenvolvimento urbano e } \\
\text { execução do Orçamento Geral da União }\end{array}$} \\
\hline Ano & Empenhado & Liquidado \\
2000 & $0,61 \%$ & $0,61 \%$ \\
2001 & $0,80 \%$ & $0,80 \%$ \\
2002 & $1,78 \%$ & $1,78 \%$ \\
2003 & $0,60 \%$ & $0,60 \%$ \\
2004 & $0,39 \%$ & $0,39 \%$ \\
2005 & $0,44 \%$ & $0,44 \%$ \\
2006 & $0,46 \%$ & $0,46 \%$ \\
2007 & $1,29 \%$ & $0,64 \%$ \\
2008 & $0,78 \%$ & $0,20 \%$ \\
2009 & $1,18 \%$ & $0,39 \%$ \\
2010 & $1,19 \%$ & $0,39 \%$ \\
2011 & $1,26 \%$ & $0,19 \%$ \\
2012 & $1,06 \%$ & $0,31 \%$ \\
2013 & $1,20 \%$ & $0,51 \%$ \\
2014 & $1,51 \%$ & $1,08 \%$ \\
2015 & $1,00 \%$ & $0,80 \%$ \\
2016 & $0,50 \%$ & $0,37 \%$ \\
\hline
\end{tabular}

Quadro 3.2: Relevância fiscal do desenvolvimento urbano: relação entre financiamento desenvolvimento urbano e execução total do OGU. Fonte: Sistema Integrado de Planejamento e Orçamento, Ministério do Planejamento, Desenvolvimento e Gestão do Governo Federal. Elaboração nossa.

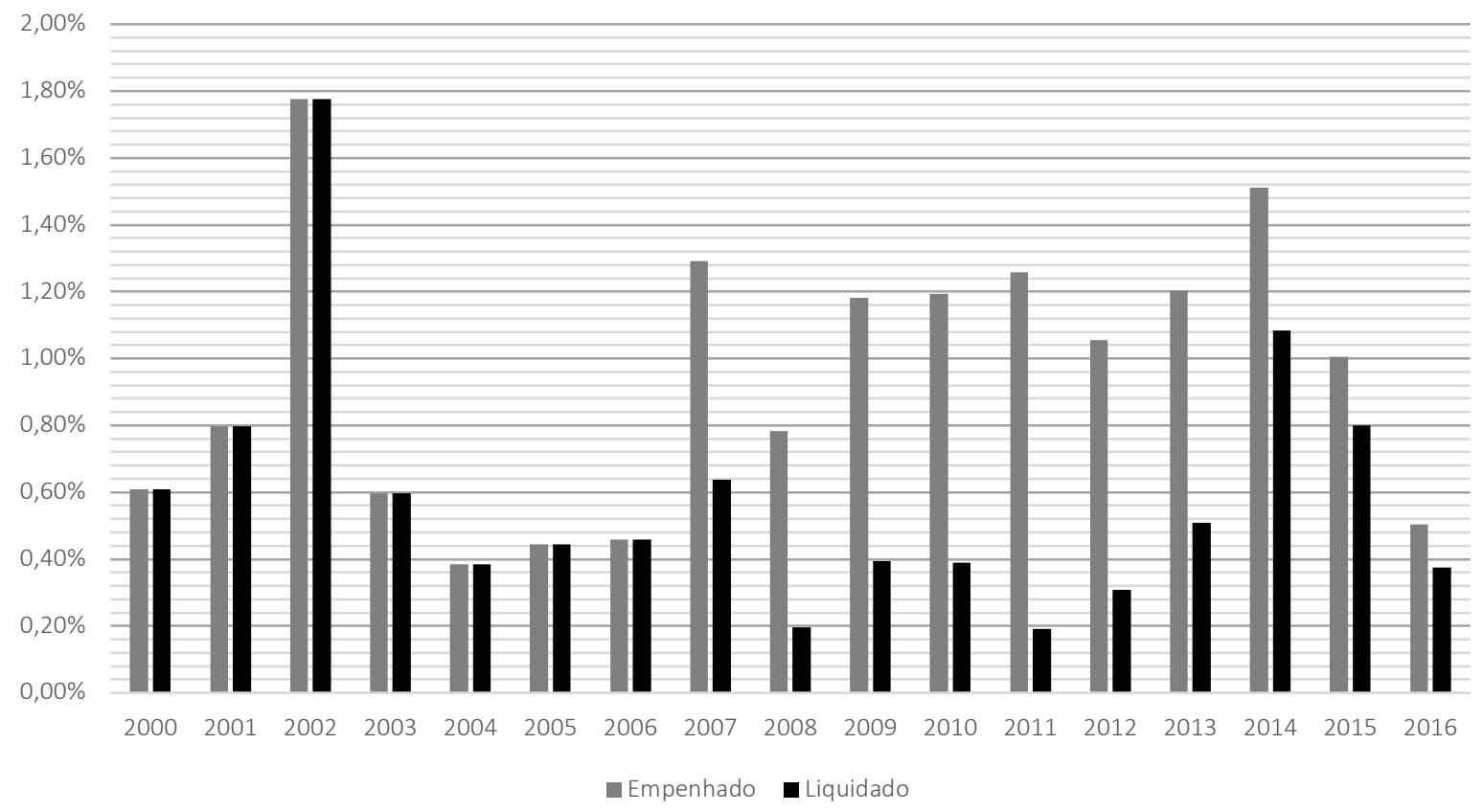

Gráfico 3.2: Relevância fiscal do desenvolvimento urbano: relação entre financiamento desenvolvimento urbano e execução total do OGU. Fonte: Sistema Integrado de Planejamento e Orçamento, Ministério do Planejamento, Desenvolvimento e Gestão do Governo Federal. Elaboração nossa. 
Sobre isso, a não vinculação de receitas prejudica a regularidade da alocação dos recursos fiscais em prol do desenvolvimento urbano, de modo que os recursos orçamentários devem ser disputados ano a ano. ${ }^{269}$ Desse modo, o orçamento público é permeado por impasses distributivos, onde é preciso escolher algo em detrimento de outros, e essas tensões são acirradas em cenário de desaceleração e recessão econômica. ${ }^{270}$ Assim sendo, também o debate sobre ajustes e saúde fiscal do governo, gastos com a previdência social e sua crescente demanda por financiamento, desonerações e subsídios fiscais, vinculação de recursos públicos e a rigidez orçamentária, despesas financeiras e a garantia da solvência pública, e a importância da reforma tributária para o financiamento de políticas públicas demonstram-se pertinentes aos estudos sobre financiamento do desenvolvimento urbano, mesmo que não tratados pelo presente estudo. ${ }^{271}$

Em associação à disputa pela alocação de recursos, é necessário o debate sobre a liquidação dos recursos empenhados, em especial se considerada a relevante dificuldade em liquidar os recursos orçamentários destinados ao desenvolvimento urbano a partir de 2007. Uma série de fatores pode ser considerada para entender a capacidade estatal em liquidar os recursos orçamentários. No caso das cooperações entre entes federados, o valor financeiro da contrapartida subnacional; a capacidade de endividamento financeiro e fiscal subnacional; licenciamento da obra financiada; titularidade do território sobre o qual dar-se-á a intervenção estatal; qualidade do projeto de intervenção; regularidade da concessão de serviços, nos casos pertinentes, a exemplo do saneamento básico; repasses financeiros em acordo com as etapas de obras, o que demanda inteligência de gestão, por exemplo, podem tornar dificultosa a

269 Devido a isso os fundos assumem relevância na administração pública, podendo garantir os recursos orçamentários conquistados pelos setoriais para além do ano orçamentário ou exercício fiscal. Deve ficar claro, contudo, que os fundos não significam a priori garantia de financiamento de políticas públicas. Cada fundo atende a estruturas regulatórias próprias, e ainda existe uma série de fundos: de repartição de receitas; de incentivos fiscais; constitucionais de financiamento; garantidores; financeiros; contábeis; e orçamentários, por exemplo. Sobre isso, a Lei Federal №4.320 de 1964 ainda é o marco regulatório nacional. A respeito da associação entre vinculação de receitas e fundos, há uma disputa em torno da ampliação de vinculações, na tentativa de garantia de políticas públicas específicas, e de redução das vinculações, na tentativa de ampliar a discricionariedade sobre os recursos orçamentários.

270 Schick, 1976; Peres, 2018.

271 O presente trabalho beneficia-se dos debates construídos no âmbito da disciplina GPP5805 - Economia e Políticas Públicas - 2S2018, ministrada pela professora doutora Ursula Dias Peres, pós-graduação em Gestão de Políticas Públicas da Universidade de São Paulo. 
execução dos recursos empenhados. ${ }^{272}$ Com atenção à execução dos recursos oriundos do Orçamento Geral da União, é possível verificar que a liquidação de recursos oscila de acordo com a modalidade de aplicação adotada, em especial: aplicações diretas realizadas pela União; transferências a estados e distrito federal; transferências a municípios (Quadro 3.3). No caso das aplicações diretas realizadas pela União, a taxa de liquidação dos recursos empenhados em desenvolvimento urbano é de $66 \%$. No caso das transferências realizadas a estados e distrito federal essa taxa cai para 43\%, e no caso das transferências para municípios essa taxa atingi a marca dos $40 \%$.

\begin{tabular}{|c|c|c|c|c|c|c|c|c|}
\hline \multicolumn{9}{|c|}{ Modalidade de aplicação dos recursos oriundos do Orçamento Geral da União em prol do desenvolvimento urbano } \\
\hline \multirow[b]{2}{*}{ Ano } & \multicolumn{4}{|c|}{ Valor Empenhado } & \multicolumn{4}{|c|}{ Valor Liquidado } \\
\hline & $\begin{array}{l}\text { Aplicação } \\
\text { Direta } \\
\text { União }\end{array}$ & $\begin{array}{l}\text { Transfe- } \\
\text { rência } \\
\text { Município }\end{array}$ & $\begin{array}{l}\text { Transfe- } \\
\text { rência } \\
\text { Estados / } \\
\text { DF }\end{array}$ & Outros & $\begin{array}{l}\text { Aplicação } \\
\text { Direta } \\
\text { União }\end{array}$ & $\begin{array}{l}\text { Transfe- } \\
\text { rência } \\
\text { Município }\end{array}$ & $\begin{array}{l}\text { Transfe- } \\
\text { rência } \\
\text { Estados / } \\
\text { DF }\end{array}$ & Outros \\
\hline 2000 & $\mathrm{R} \$ 6.406$ & $\mathrm{R} \$ 2.377$ & $\mathrm{R} \$ 1.740$ & $\mathrm{R} \$ 166$ & $\mathrm{R} \$ 6.406$ & $\mathrm{R} \$ 2.377$ & $\mathrm{R} \$ 1.740$ & $\mathrm{R} \$ 166$ \\
\hline 2001 & $\mathrm{R} \$ 3.179$ & $\mathrm{R} \$ 5.307$ & $\mathrm{R} \$ 4.095$ & $\mathrm{R} \$ 153$ & $\mathrm{R} \$ 3.179$ & $\mathrm{R} \$ 5.307$ & $\mathrm{R} \$ 4.095$ & $\mathrm{R} \$ 153$ \\
\hline 2002 & $\mathrm{R} \$ 24.136$ & $\mathrm{R} \$ 2.990$ & $\mathrm{R} \$ 1.359$ & $\mathrm{R} \$ 151$ & $\mathrm{R} \$ 24.136$ & $\mathrm{R} \$ 2.990$ & $\mathrm{R} \$ 1.359$ & $\mathrm{R} \$ 151$ \\
\hline 2003 & $\mathrm{R} \$ 9.264$ & $\mathrm{R} \$ 1.480$ & $\mathrm{R} \$ 435$ & $\mathrm{R} \$ 63$ & $\mathrm{R} \$ 9.264$ & $\mathrm{R} \$ 1.480$ & $\mathrm{R} \$ 435$ & $\mathrm{R} \$ 63$ \\
\hline 2004 & $\mathrm{R} \$ 3.835$ & $\mathrm{R} \$ 2.460$ & $\mathrm{R} \$ 608$ & $\mathrm{R} \$ 129$ & $R \$ 3.835$ & $\mathrm{R} \$ 2.460$ & $\mathrm{R} \$ 608$ & $\mathrm{R} \$ 129$ \\
\hline 2005 & $R \$ 4.415$ & $R \$ 3.840$ & $R \$ 884$ & $\mathrm{R} \$ 134$ & $\mathrm{R} \$ 4.415$ & $R \$ 3.840$ & $R \$ 884$ & $\mathrm{R} \$ 134$ \\
\hline 2006 & $\mathrm{R} \$ 3.492$ & $\mathrm{R} \$ 5.718$ & $\mathrm{R} \$ 600$ & $\mathrm{R} \$ 196$ & $\mathrm{R} \$ 3.492$ & $\mathrm{R} \$ 5.718$ & $\mathrm{R} \$ 600$ & $\mathrm{R} \$ 196$ \\
\hline 2007 & $\mathrm{R} \$ 14.051$ & $\mathrm{R} \$ 7.913$ & $R \$ 5.595$ & $\mathrm{R} \$ 284$ & $\mathrm{R} \$ 11.818$ & $\mathrm{R} \$ 180$ & $\mathrm{R} \$ 980$ & $\mathrm{R} \$ 229$ \\
\hline 2008 & $R \$ 3.650$ & $\mathrm{R} \$ 7.427$ & $\mathrm{R} \$ 5.095$ & $\mathrm{R} \$ 208$ & $\mathrm{R} \$ 1.603$ & $\mathrm{R} \$ 1.264$ & R\$ 898 & $\mathrm{R} \$ 170$ \\
\hline 2009 & $\mathrm{R} \$ 13.115$ & $\mathrm{R} \$ 8.328$ & $\mathrm{R} \$ 4.906$ & R\$ 239 & $\mathrm{R} \$ 5.382$ & $\mathrm{R} \$ 1.503$ & $\mathrm{R} \$ 1.421$ & $\mathrm{R} \$ 150$ \\
\hline 2010 & $\mathrm{R} \$ 17.201$ & $R \$ 5.507$ & $R \$ 3.975$ & $R \$ 249$ & $R \$ 5.736$ & $\mathrm{R} \$ 750$ & $\mathrm{R} \$ 1.709$ & $R \$ 165$ \\
\hline 2011 & $R \$ 20.627$ & $R \$ 5.783$ & $R \$ 2.976$ & $R \$ 356$ & $R \$ 2.752$ & $\mathrm{R} \$ 611$ & $\mathrm{R} \$ 742$ & $\mathrm{R} \$ 182$ \\
\hline 2012 & $\mathrm{R} \$ 18.985$ & $\mathrm{R} \$ 4.641$ & $\mathrm{R} \$ 2.166$ & $\mathrm{R} \$ 251$ & $\mathrm{R} \$ 5.315$ & $\mathrm{R} \$ 1.165$ & $\mathrm{R} \$ 540$ & $\mathrm{R} \$ 143$ \\
\hline 2013 & $\mathrm{R} \$ 21.689$ & $R \$ 4.919$ & $R \$ 2.408$ & $R \$ 235$ & $\mathrm{R} \$ 10.757$ & $\mathrm{R} \$ 341$ & $R \$ 373$ & $\mathrm{R} \$ 147$ \\
\hline 2014 & $\mathrm{R} \$ 36.454$ & $R \$ 3.031$ & $\mathrm{R} \$ 1.927$ & $\mathrm{R} \$ 128$ & $\mathrm{R} \$ 27.404$ & $R \$ 248$ & $R \$ 597$ & $\mathrm{R} \$ 74$ \\
\hline 2015 & $\mathrm{R} \$ 21.160$ & $R \$ 3.597$ & $\mathrm{R} \$ 734$ & $\mathrm{R} \$ 115$ & $\mathrm{R} \$ 19.283$ & $R \$ 341$ & $\mathrm{R} \$ 45$ & $R \$ 69$ \\
\hline 2016 & $\mathrm{R} \$ 10.062$ & $R \$ 2.533$ & $\mathrm{R} \$ 682$ & $\mathrm{R} \$ 105$ & $\mathrm{R} \$ 8.756$ & $R \$ 457$ & $R \$ 403$ & $R \$ 64$ \\
\hline Total & $R \$ 231.723$ & $\mathrm{R} \$ 77.852$ & $\mathrm{R} \$ 40.186$ & $R \$ 3.161$ & $\mathrm{R} \$ 153.534$ & $\mathrm{R} \$ 31.035$ & $\mathrm{R} \$ 17.431$ & $\mathrm{R} \$ 2.384$ \\
\hline \multicolumn{9}{|c|}{ Relação Liquidação / Empenho } \\
\hline & \multicolumn{2}{|c|}{$\begin{array}{l}\text { Aplicação Direta } \\
\text { União }\end{array}$} & \multicolumn{2}{|c|}{$\begin{array}{l}\text { Transferências a } \\
\text { Municípios }\end{array}$} & \multicolumn{2}{|c|}{$\begin{array}{l}\text { Transferências a } \\
\text { Estados / DF }\end{array}$} & \multicolumn{2}{|l|}{ Outros } \\
\hline & \multicolumn{2}{|l|}{$66 \%$} & $40 \%$ & & \multicolumn{2}{|l|}{$43 \%$} & \multicolumn{2}{|l|}{$75 \%$} \\
\hline
\end{tabular}

Quadro 3.3: Modalidade de aplicação recursos orçamentários destinados ao desenvolvimento urbano - Empenho e Liquidação. Valores em milhões. Ano referência de valores: 2016. Fonte: Sistema Integrado de Planejamento e Orçamento, Ministério do Planejamento, Desenvolvimento e Gestão do Governo Federal. Elaboração nossa.

\footnotetext{
272 Ver Kuhn, 2018.
} 
Apresentamos anteriormente que a criação do Ministério das Cidades (2003), do Sistema Nacional de Habitação de Interesse Social (2005) e do Fundo Nacional de Habitação de Interesse Social (2005) não está associada a uma forte ampliação dos recursos destinados ao desenvolvimento urbano. Contudo, há sim uma relação temporal entre a construção de institucionalidades federais e a modalidade de aplicação dos recursos fiscais. No que se refere ao desenvolvimento urbano, entre 2003 e 2008 verifica-se importante esforço federal em descentralizar a execução dos recursos oriundos do OGU, em especial por meio das transferências a municípios (Quadro 3.3; Gráfico 3.3). Trata-se, em certa medida, do atendimento dos preceitos apresentados pela Constituição de 1988, que amplia as responsabilidades de esfera local frente ao desenvolvimento urbano. No ano de 2008 apenas $22 \%$ dos recursos empenhados em prol do desenvolvimento urbano seriam aplicados diretamente pela União, quase $50 \%$ pelos municípios, e cerca de $30 \%$ pelos estados e distrito federal. O que parece ter ficado claro dessa experiência histórica das políticas urbanas e habitacionais são os desafios em torno da construção de capacidades subnacionais em torno das políticas urbanas e habitacionais. No entanto, a esfera federal desempenha um papel central na formulação, regulação, financiamento de políticas públicas no país, o que acaba por induzir a construção de capacidades subnacionais, orientada pela captação de recursos e a execução descentralizada de políticas públicas nacionais. Neste sentido, mesmo os municipalistas devem reconhecer o papel a ser desempenhado pela União no financiamento do desenvolvimento urbano, com resultados possíveis apenas a médio prazo. 


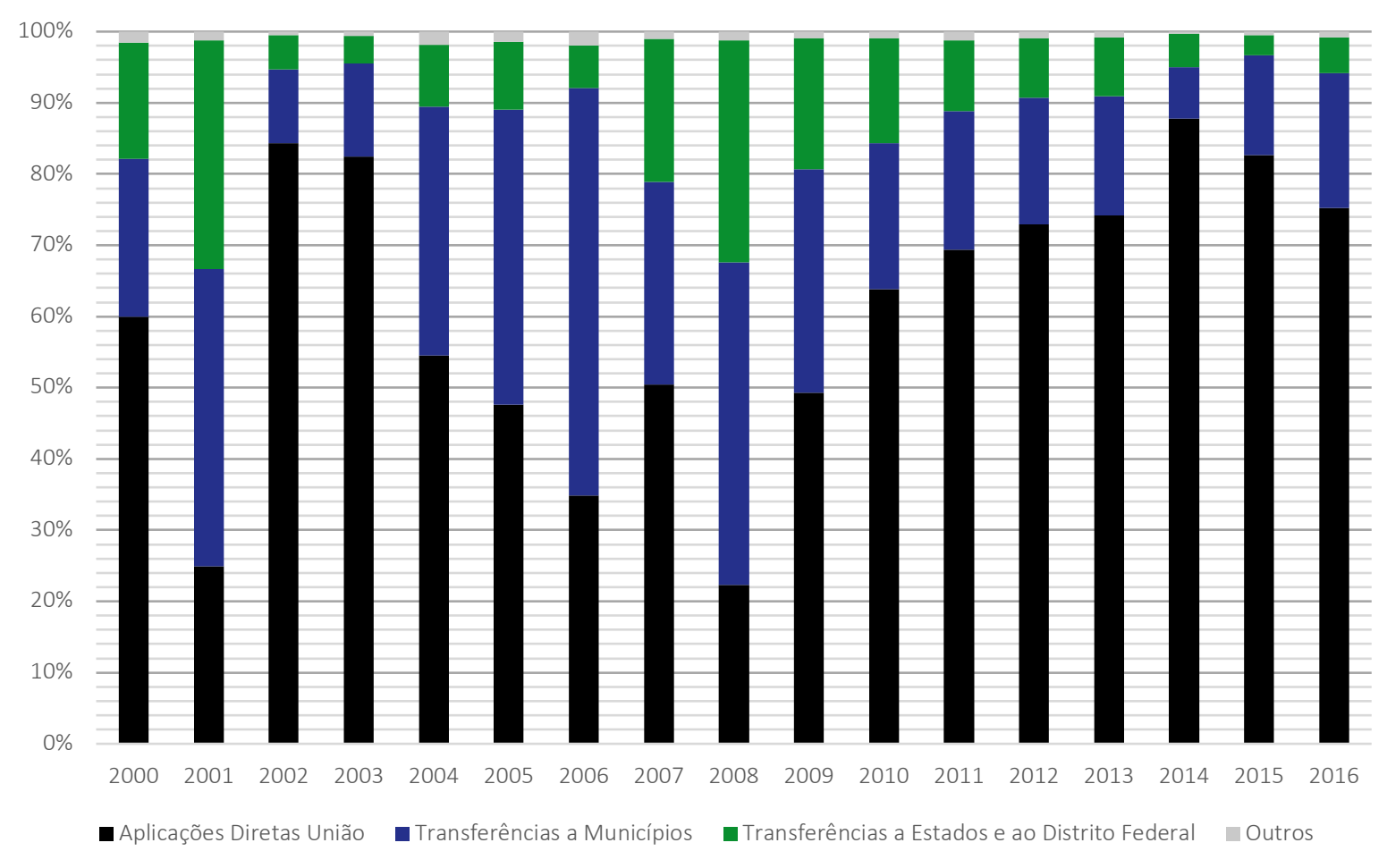

Gráfico 3.3: Modalidade de aplicação recursos orçamentários destinados ao desenvolvimento urbano - Empenho. Ano referência de valores: 2016. Fonte: Sistema Integrado de Planejamento e Orçamento, Ministério do Planejamento, Desenvolvimento e Gestão do Governo Federal. Elaboração nossa.

Sobre isso, é corrente no campo das políticas urbanas e habitacionais dedicar centralidade às fragilidades administrativas e financeiras de entes subnacionais frente ao mau desempenho do SNHIS e FNHIS. A execução do Orçamento Geral da União demonstra, contudo, que há também uma importante redução dos recursos destinados ou sob supervisão do FNHIS, mesmo antes do Programa Minha Casa, Minha Vida. Neste sentido, é relevante entender que a criação de um fundo de natureza contábil não garante a alocação de recursos orçamentários. Mesmo em 2006, o total de recursos destinados ao FNHIS pouco supera a marca dos R\$2 bilhões de reais (Quadro 3.4; Gráfico 3.4). 


\begin{tabular}{|c|c|c|}
\hline \multicolumn{3}{|c|}{$\begin{array}{l}\text { Recursos orçamentários federais destinados ou sob supervisão do Fundo Nacional de Habitação de Interesse } \\
\text { Social }\end{array}$} \\
\hline Ano & Empenhado & Liquidado \\
\hline 2006 & $R \$ 2.141 .398 .239$ & $R \$ 2.141 .398 .239$ \\
\hline 2007 & $R \$ 1.057 .116 .073$ & $R \$ 673.444$ \\
\hline 2008 & $R \$ 1.759 .236 .821$ & $R \$ 252.963 .780$ \\
\hline 2009 & $R \$ 1.610 .712 .686$ & $R \$ 215.639 .515$ \\
\hline 2010 & $R \$ 263.843 .325$ & $R \$ 32.119 .084$ \\
\hline 2011 & $R \$ 716.417 .232$ & $R \$ 84.263 .136$ \\
\hline 2012 & $R \$ 755.299 .178$ & $\mathrm{R} \$ 179.007 .982$ \\
\hline 2013 & $R \$ 261.130 .216$ & $\mathrm{R} \$ 14.514 .450$ \\
\hline 2014 & $R \$ 56.414 .524$ & $\mathrm{R} \$ 8.838 .575$ \\
\hline 2015 & $\mathrm{R} \$ 73.622 .621$ & $R \$ 2.566 .756$ \\
\hline 2016 & $\mathrm{R} \$ 38.162 .827$ & $R \$ 9.405 .847$ \\
\hline Total & $\mathrm{R} \$ 8.733 .353 .743$ & $R \$ 2.941 .390 .809$ \\
\hline Relação Liquidação / Empenho & & $34 \%$ \\
\hline
\end{tabular}

Quadro 3.4: Recursos orçamentários federais destinados ou sob supervisão do Fundo Nacional de Habitação de Interesse Social (FNHIS) entre 2006 e 2016 (Unidades orçamentárias 56902; 74911). Ano referência de valores: 2016. Fonte: Sistema Integrado de Planejamento e Orçamento, Ministério do Planejamento, Desenvolvimento e Gestão do Governo Federal. Elaboração nossa.

$R \$ 2.500 .000 .000$

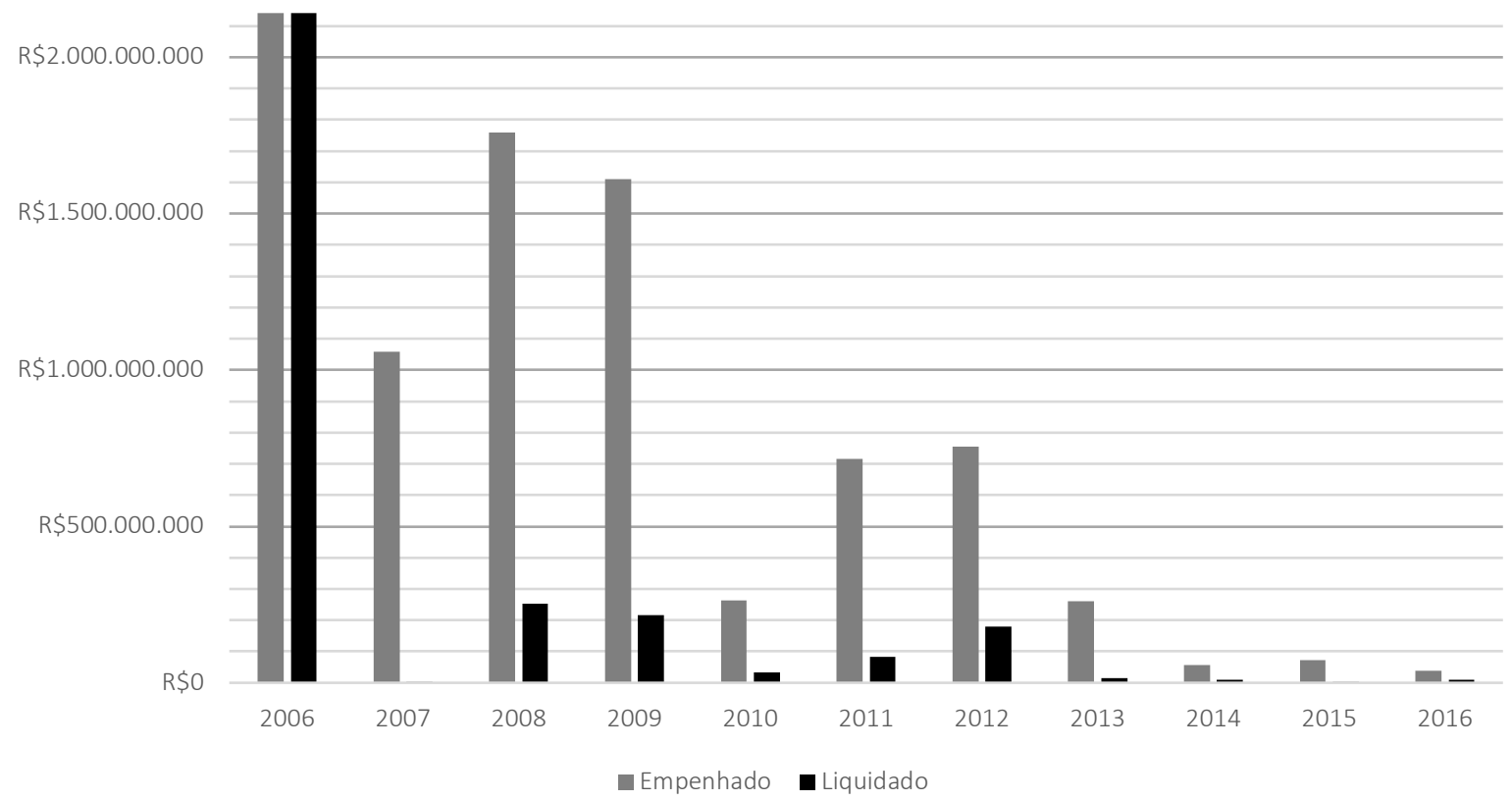

Gráfico 3.4: Recursos orçamentários federais destinados ou sob supervisão do Fundo Nacional de Habitação de Interesse Social (FNHIS) entre 2006 e 2016 (Unidades orçamentárias 56902; 74911). Ano referência de valores: 2016. Fonte: Sistema Integrado de Planejamento e Orçamento, Ministério do Planejamento, Desenvolvimento e Gestão do Governo Federal. Elaboração nossa. 
Articular as observações já apresentadas nos permite a apresentação de uma hipótese. A associação entre o resgate de mecanismos de intervenção federal na economia, a construção de uma importância política e econômica dos investimentos na manutenção e dinamização do crescimento econômico com inclusão social, as dificuldades na liquidação de recursos a partir da cooperação entre entes federados, por exemplo, podem ter subsidiado a opção federal por recentralizar a execução dos recursos fiscais frente à crise econômica de $2009 .{ }^{273}$ Em 2008 cerca de $20 \%$ dos recursos destinados ao desenvolvimento urbano seriam aplicados diretamente pela União, taxa que cresce consistentemente entre 2008 e 2016, atingindo a marca de 80\% em 2015 (Quadro 3.3; Gráfico 3.3). Observar a destinação de recursos orçamentários ao Programa Minha Casa, Minha Vida (PMCMV) ilustra esse debate (Quadro 3.5; Gráfico 3.5). ${ }^{274}$

Em termos financeiros, é possível comparar a produção efetivada pelo SNHIS àquela produzida pelo PMCMV. Se o FNHIS chega a liquidar R\$2,9 bilhões entre 2006 e 2016, o PMCMV liquida um total de $\mathrm{R} \$ 52,6$ bilhões de recursos oriundos do Orçamento Geral da União. Entender os tipos de projetos financiados, as capacidades administrativas e a modalidade de aplicação dos recursos ajudam a entender a racionalidade estatal por trás dessa opção de política pública.

\begin{tabular}{lll}
\hline Recursos orçamentários federais destinados às diferentes modalidades do & Programa Minha Casa, Minha Vida \\
\hline Ano & Empenhado & Liquidado \\
2009 & $\mathrm{R} \$ 8.339,57$ & $\mathrm{R} \$ 3.365,56$ \\
2010 & $\mathrm{R} \$ 10.045,03$ & $\mathrm{R} \$ 215,51$ \\
2011 & $\mathrm{R} \$ 15.482,85$ & $\mathrm{R} \$ 844,56$ \\
2012 & $\mathrm{R} \$ 15.013,10$ & $\mathrm{R} \$ 3.305,82$ \\
2013 & $\mathrm{R} \$ 18.530,92$ & $\mathrm{R} \$ 8.406,27$ \\
2014 & $\mathrm{R} \$ 19.786,04$ & $\mathrm{R} \$ 13.239,93$ \\
2015 & $\mathrm{R} \$ 17.713,33$ & $\mathrm{R} \$ 16.523,52$ \\
2016 & $\mathrm{R} \$ 6.916,67$ & $\mathrm{R} \$ 6.720,24$ \\
Total & $\mathrm{R} \$ 111.827,52$ & $\mathrm{R} \$ 52.621,41$ \\
Relação Liquidação / Empenho & & $47 \%$ \\
\hline
\end{tabular}

Quadro 3.5: Recursos orçamentários federais destinados às diferentes modalidades do Programa Minha Casa, Minha Vida, inclusive a Rural (Ações orçamentárias: 00AF; 00CW; 00CX; OOCY; OE64). Valores em milhões. Ano referência de valores: 2016. Fonte: Sistema Integrado de Planejamento e Orçamento, Ministério do Planejamento, Desenvolvimento e Gestão do Governo Federal. Elaboração nossa.

273 Debate construído no grupo de pesquisa CNPq "Produção do espaço urbano e finanças contemporâneas: o papel do fundo público", coordenado pela professora Luciana de Oliveira Royer, sediado no LABHAB-FAU-USP.

274 O Programa Minha Casa, Minha Vida é iniciado em 2009. Contudo, sua operacionalização no Orçamento Geral da União dá-se também por meio de ações orçamentárias existentes pré-2009. 


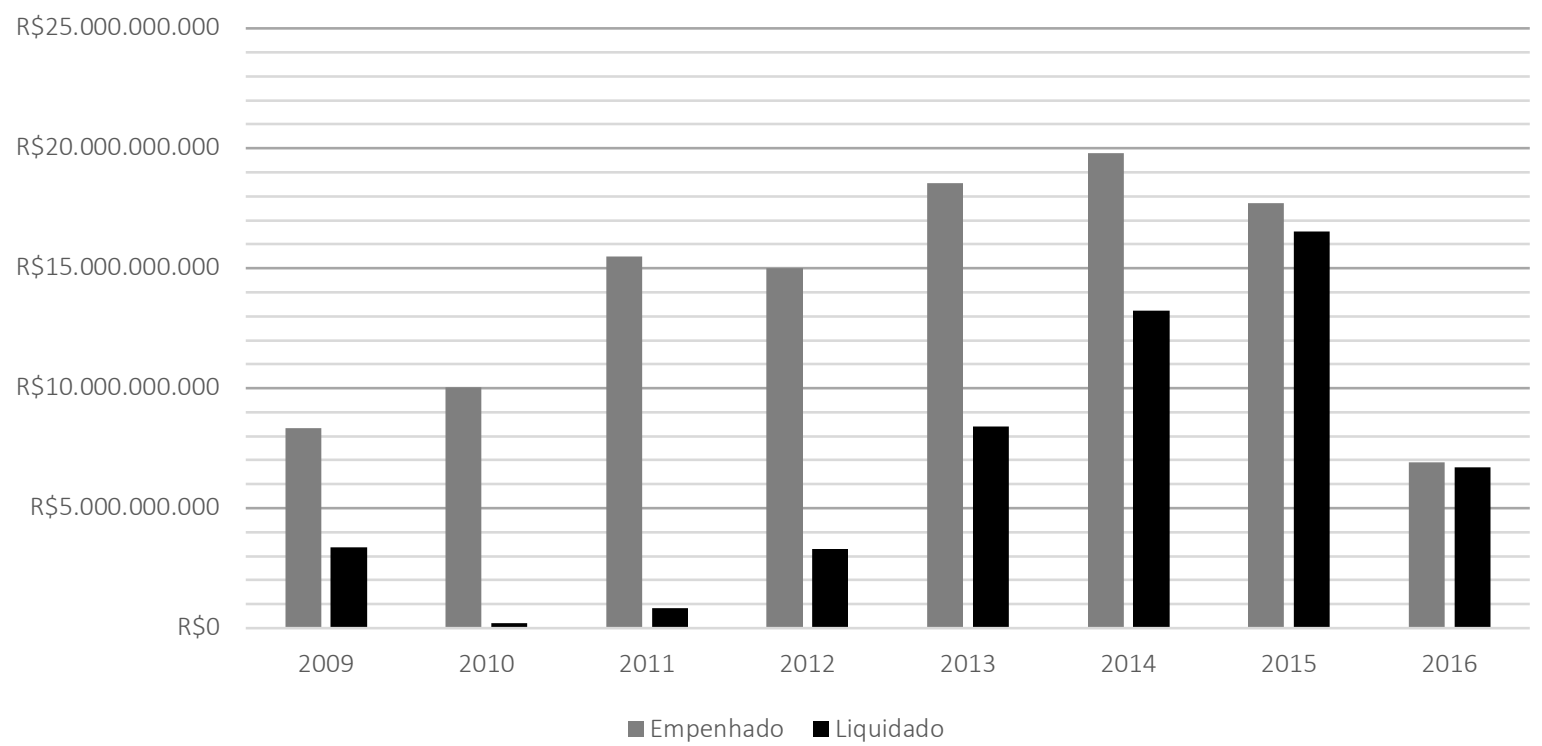

Gráfico 3.5: Recursos orçamentários federais destinados às diferentes modalidades do Programa Minha Casa, Minha Vida, inclusive a Rural (Ações orçamentárias: 00AF; 00CW; 00CX; 00CY; OE64). Ano referência de valores: 2016. Fonte: Sistema Integrado de Planejamento e Orçamento, Ministério do Planejamento, Desenvolvimento e Gestão do Governo Federal. Elaboração nossa.

É notório que o SNHIS dedicou importância à operacionalização do financiamento de urbanizações de assentamentos precários (Cardoso; Jaenisch; Aragão, 2017), um tipo de intervenção urbana complexificada, seja em termos econômicos, políticos ou sociais. ${ }^{275}$ Operacionalizar os recursos do Orçamento Geral da União a partir do sistema bancário brasileiro, ${ }^{276}$ com destaque ao papel desempenhado pela Caixa Econômica Federal, a partir da atuação de agentes privados do subsetor produtivo imobiliário habitacional, e com vistas à produção de novas unidades habitacionais, implica parcialmente 277 excluir da equação as fragilidades administrativas e financeiras subnacionais, mas também escapar da complexidade dos assentamentos precários. Em termos de política pública, essa escolha apresenta ganhos e perdas, mas certamente os ganhos sociais apenas são possíveis a partir do subsídio à população de mais baixa renda no acesso à casa própria, sendo este papel desempenhado pelos recursos orçamentários federais aplicados a "fundo perdido".

\footnotetext{
${ }^{275}$ Cf. Cardoso e Denaldi, 2018.

276 Sobre o desenho e operação do PMCMV ver Cardoso e Aragão, 2013.

277 Cabe lembrar, mesmo que não produzindo habitações, a esfera local participou ativamente da operação do PMCMV, seja em termos de licenciamento dos empreendimentos imobiliários, seja em termos da regulação do mercado fundiário e do uso e ocupação do solo urbano, seja em termos da concessão de lotes, por exemplo.
} 
Entendida a engenharia financeira do PMCMV, os recursos oriundos do Orçamento Geral da União e destinados ao Fundo de Arrendamento Residencial (FAR) ou Fundo de Desenvolvimento Social (FDS), ambos sob a gestão da CEF, demonstram-se centrais para tencionar o caráter economicista da política habitacional federal predominante a partir de 2009, propriamente uma política de crédito imobiliário habitacional, conferindo a esta uma dimensão social, própria da política habitacional. Em associação, o acirramento dos ajustes fiscais federais também exerce influência sobre a operacionalização do PMCMV, uma vez que a destinação de recursos orçamentários esteve descompassada da contratação de financiamento imobiliário operacionalizada pela CEF, o que implica atraso ou inviabilização das obras de novas unidades habitacionais por todo o país. ${ }^{278}$ Certamente as questões urbanas, econômicas, sociais e políticas do PMCMV não se resumem ao subsídio direto às famílias, debate que perpassa a compreensão de uma política habitacional enquanto atendimento das necessidades habitacionais, e não necessariamente a construção de novas unidades. ${ }^{279}$

Por fim, cabe avaliar os órgãos federais responsáveis pelos recursos orçamentários (Quadro 3.6; Gráfico 3.6). A empiria demonstra que uma série de órgãos federais são responsáveis por articular recursos que, ora ou outra, manifestam-se em prol do desenvolvimento urbano. Desses, quatro órgãos são centrais: Ministério das Cidades, Ministério da Saúde, Ministério da Fazenda e Ministério da Integração Nacional, além dos Encargos Financeiros da União, estes também entendidos enquanto órgão orçamentário.

Com atenção ao empenho de recursos orçamentários, o Ministério das Cidades demonstra uma crescente capacidade na articulação entre políticas e recursos financeiros, assumindo centralidade perante as políticas urbanas e habitacionais federais. ${ }^{280}$ Isso representa, ao menos em parte, a importância desse ministério para a construção de

\footnotetext{
278 "Governo deve R\$ 500 mi para empreiteiras do Minha Casa Minha Vida. A maioria é de empresas responsáveis pelas construções dos imóveis de baixa renda". Disponível em: <https://www1.folha.uol.com.br/mercado/2019/10/governo-deve-r-500-mi-para-empreiteiras-do-minha-casaminha-vida.shtml>, consultado em outubro de 2019.

${ }^{279}$ Cf. Bolaffi, 1975.

${ }^{280}$ A literatura já demonstrou que, após a extinção do BNH, a “[...]questão habitacional percorreu uma verdadeira 'via-crúcis institucional' desde 1986" (Arretche, 1998 apud Royer, 2009; p.95), o que ressalta a relevância histórica desse momento para as políticas urbanas e habitacionais no país.
} 
institucionalidades relativas ao desenvolvimento urbano, em grande medida expressas pelo arcabouço regulatório elencado no capítulo 1, mas também pela realização de planos e estudos técnicos, a exemplo dos planos nacionais de habitação, saneamento básico e mobilidade urbana, por exemplo. Isso está em acordo com a criação do Ministério, proposto enquanto um órgão de planejamento na esfera federal, central para a articulação federativa ou mesmo a construção de capacidades, inclusive subnacionais, em torno das políticas urbanas e habitacionais. Destaca-se a série de concursos públicos realizados para composição de corpo técnico permanente do Ministério das Cidades, também elemento de destaque para a compreensão dos dados financeiros aqui apresentados. Já se demonstrou a relevância do PMCMV na composição do financiamento fiscal do desenvolvimento urbano, responsável por condensar mais de $25 \%$ dos recursos liquidados. O PMCMV foi apresentado pela Casa Civil da Presidência da República mas, por mais que faltem evidências a este trabalho, cabe salientar a importância extra-financeira atribuída à Secretaria Nacional de Habitação para o programa, responsável em grande medida pela elaboração de marco regulatório programático próprio, incorporando incrementalmente melhorias à operacionalização do PMCMV. ${ }^{281}$

De acordo com o Manual Técnico do Orçamento do Governo Federal versão 2016,282 os Encargos Financeiros da União podem estar sob supervisão do Ministério da Fazenda, do Ministério do Planejamento, Orçamento e Gestão, destinados ao pagamento de sentenças judiciais, à remuneração de agentes financeiros e sob supervisão do Ministério da Fazenda, sob supervisão do Ministério da Agricultura, Pecuária e Abastecimento, sob supervisão do Ministério de Minas e Energia, destinados ao Fundo Contingente da Extinta RFFSA sob supervisão do Ministério da Fazenda, destinados ao Fundo Soberano do Brasil sob supervisão do Ministério da Fazenda e destinados ao Fundo Social. Os Encargos Financeiros da União relativos ao desenvolvimento urbano são especialmente expressivos nos anos de 2002, 2007 e 2014.283

\footnotetext{
${ }^{281}$ A Caixa Econômica Federal elencou uma série de normativas relativas ao PMCMV-FAR, por exemplo. Ver: <https://www.caixa.gov.br/Downloads/habitacao-minha-casa-minha-vida/_Legislacao_FAR.pdf>, situação julho de 2018, consultado em outubro de 2019.

$282 \quad$ Disponível em: <http://www.orcamentofederal.gov.br/informacoes-orcamentarias/manualtecnico/mto_2016_1aedicao-200515.pdf>, consultado em outubro de 2019.

283 O detalhamento de ações será apresentado pela próxima seção.
} 


\begin{tabular}{|c|c|c|c|c|c|c|}
\hline \multicolumn{7}{|c|}{ Responsabilidade pelos recursos orçamentários federais destinados ao desenvolvimento urbano } \\
\hline & \multicolumn{6}{|c|}{ Empenho } \\
\hline & 56000 & 71000 & 36000 & 25000 & 53000 & Outros \\
\hline & Ministério & Encargos & Ministério & Ministério & Ministério & \\
\hline & das Cidades & Financeiros da & da Saúde & da Fazenda & da Integração & \\
\hline & & União & & & Nacional & \\
\hline 2000 & $\mathrm{R} \$-$ & 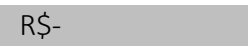 & $\mathrm{R} \$ 702$ & $R \$ 3.924$ & $\mathrm{R} \$ 1.601$ & $R \$ 4.461$ \\
\hline 2001 & $R \$-$ & $\mathrm{R} \$-$ & $R \$ 3.617$ & $\mathrm{R} \$ 356$ & $\mathrm{R} \$ 2.747$ & $R \$ 6.014$ \\
\hline 2002 & $\mathrm{R} \$-$ & $\mathrm{R} \$ 16.733$ & $\mathrm{R} \$ 1.554$ & $R \$ 3.234$ & $\mathrm{R} \$ 1.096$ & $R \$ 6.019$ \\
\hline 2003 & $\mathrm{R} \$ 1.871$ & $\mathrm{R} \$ 4.952$ & $\mathrm{R} \$ 414$ & $R \$ 2.219$ & $\mathrm{R} \$ 493$ & $\mathrm{R} \$ 1.292$ \\
\hline 2004 & $R \$ 2.767$ & $\mathrm{R} \$-$ & $R \$ 1.166$ & $\mathrm{R} \$ 1.438$ & $R \$ 373$ & $\mathrm{R} \$ 1.289$ \\
\hline 2005 & $\mathrm{R} \$ 4.220$ & $\mathrm{R} \$-$ & $R \$ 1.403$ & $R \$ 1.075$ & $\mathrm{R} \$ 843$ & $R \$ 1.733$ \\
\hline 2006 & $R \$ 5.579$ & $\mathrm{R} \$-$ & $\mathrm{R} \$ 1.804$ & $\mathrm{R} \$ 1.201$ & $\mathrm{R} \$ 531$ & $\mathrm{R} \$ 892$ \\
\hline 2007 & $\mathrm{R} \$ 11.602$ & $R \$ 9.159$ & $\mathrm{R} \$ 2.302$ & $\mathrm{R} \$ 1.116$ & $\mathrm{R} \$ 1.919$ & $\mathrm{R} \$ 1.746$ \\
\hline 2008 & $\mathrm{R} \$ 10.698$ & $\mathrm{R} \$-$ & $\mathrm{R} \$ 1.540$ & $\mathrm{R} \$ 1.190$ & $\mathrm{R} \$ 1.899$ & $\mathrm{R} \$ 1.052$ \\
\hline 2009 & $R \$ 20.952$ & $\mathrm{R} \$ 1.191$ & $R \$ 1.532$ & $\mathrm{R} \$ 1.172$ & $R \$ 1.108$ & $\mathrm{R} \$ 631$ \\
\hline 2010 & $\mathrm{R} \$ 18.923$ & $R \$ 3.445$ & $R \$ 1.365$ & $R \$ 1.071$ & $R \$ 1.391$ & $R \$ 737$ \\
\hline 2011 & $\mathrm{R} \$ 23.766$ & $R \$ 1.924$ & $R \$ 1.695$ & $R \$ 824$ & $\mathrm{R} \$ 817$ & $\mathrm{R} \$ 716$ \\
\hline 2012 & $R \$ 23.236$ & $\mathrm{R} \$ 107$ & $\mathrm{R} \$ 1.459$ & $\mathrm{R} \$ 682$ & $R \$ 388$ & $\mathrm{R} \$ 171$ \\
\hline 2013 & $\mathrm{R} \$ 25.840$ & $\mathrm{R} \$ 101$ & $R \$ 1.600$ & $\mathrm{R} \$ 1.133$ & $R \$ 359$ & $R \$ 219$ \\
\hline 2014 & $R \$ 25.360$ & $\mathrm{R} \$ 12.590$ & $R \$ 853$ & $R \$ 2.077$ & $R \$ 329$ & $\mathrm{R} \$ 330$ \\
\hline 2015 & $R \$ 22.850$ & $\mathrm{R} \$ 311$ & $R \$ 581$ & $R \$ 810$ & $\mathrm{R} \$ 54$ & $R \$ 1.000$ \\
\hline 2016 & $\mathrm{R} \$ 10.803$ & $\mathrm{R} \$-$ & $\mathrm{R} \$ 829$ & $\mathrm{R} \$ 839$ & $\mathrm{R} \$ 59$ & $R \$ 852$ \\
\hline \multirow[t]{2}{*}{ Total } & $R \$ 208.469$ & $\mathrm{R} \$ 50.515$ & $\mathrm{R} \$ 24.414$ & $\mathrm{R} \$ 24.362$ & $\mathrm{R} \$ 16.007$ & $\mathrm{R} \$ 29.154$ \\
\hline & \multicolumn{6}{|c|}{ Liquidação } \\
\hline 2000 & $\mathrm{R} \$-$ & $\mathrm{R} \$-$ & $\mathrm{R} \$ 702$ & $R \$ 3.924$ & $\mathrm{R} \$ 1.601$ & $\mathrm{R} \$ 4.461$ \\
\hline 2001 & $\mathrm{R} \$-$ & $R \$-$ & $R \$ 3.617$ & $R \$ 356$ & $R \$ 2.747$ & $R \$ 6.014$ \\
\hline 2002 & $\mathrm{R} \$-$ & $\mathrm{R} \$ 16.733$ & $\mathrm{R} \$ 1.554$ & $\mathrm{R} \$ 3.234$ & $\mathrm{R} \$ 1.096$ & $R \$ 6.019$ \\
\hline 2003 & $\mathrm{R} \$ 1.871$ & $\mathrm{R} \$ 4.952$ & $\mathrm{R} \$ 414$ & $R \$ 2.219$ & $\mathrm{R} \$ 493$ & $\mathrm{R} \$ 1.292$ \\
\hline 2004 & $R \$ 2.767$ & $\mathrm{R} \$-$ & $\mathrm{R} \$ 1.166$ & $R \$ 1.438$ & $R \$ 373$ & $\mathrm{R} \$ 1.289$ \\
\hline 2005 & $\mathrm{R} \$ 4.220$ & $\mathrm{R} \$-$ & $\mathrm{R} \$ 1.403$ & $\mathrm{R} \$ 1.075$ & $R \$ 843$ & $\mathrm{R} \$ 1.733$ \\
\hline 2006 & $R \$ 5.579$ & $\mathrm{R} \$-$ & $\mathrm{R} \$ 1.804$ & $R \$ 1.201$ & $\mathrm{R} \$ 531$ & $\mathrm{R} \$ 892$ \\
\hline 2007 & $R \$ 2.304$ & $R \$ 9.159$ & $\mathrm{R} \$ 122$ & $\mathrm{R} \$ 308$ & $\mathrm{R} \$ 374$ & $\mathrm{R} \$ 941$ \\
\hline 2008 & $R \$ 2.595$ & $\mathrm{R} \$-$ & $\mathrm{R} \$ 74$ & $\mathrm{R} \$ 419$ & $\mathrm{R} \$ 345$ & $\mathrm{R} \$ 501$ \\
\hline 2009 & $R \$ 7.209$ & $R \$-$ & $R \$ 80$ & $R \$ 535$ & $R \$ 267$ & $R \$ 365$ \\
\hline 2010 & $R \$ 3.443$ & $R \$ 3.445$ & $\mathrm{R} \$ 111$ & $R \$ 336$ & $R \$ 634$ & $\mathrm{R} \$ 392$ \\
\hline 2011 & $R \$ 2.837$ & $\mathrm{R} \$-$ & $R \$ 326$ & $R \$ 285$ & $\mathrm{R} \$ 418$ & $\mathrm{R} \$ 423$ \\
\hline 2012 & $R \$ 5.680$ & $\mathrm{R} \$-$ & $R \$ 632$ & $R \$ 616$ & $\mathrm{R} \$ 149$ & $\mathrm{R} \$ 87$ \\
\hline 2013 & $\mathrm{R} \$ 10.103$ & $R \$-$ & $R \$ 227$ & $R \$ 940$ & $R \$ 216$ & $\mathrm{R} \$ 131$ \\
\hline 2014 & $\mathrm{R} \$ 15.143$ & $\mathrm{R} \$ 12.398$ & $\mathrm{R} \$ 179$ & $R \$ 235$ & $\mathrm{R} \$ 125$ & $R \$ 243$ \\
\hline 2015 & $\mathrm{R} \$ 17.955$ & $\mathrm{R} \$ 107$ & $R \$ 149$ & $R \$ 681$ & $R \$ 9$ & $R \$ 838$ \\
\hline 2016 & $R \$ 8.552$ & $\mathrm{R} \$-$ & $\mathrm{R} \$ 300$ & $R \$-$ & $\mathrm{R} \$ 10$ & $\mathrm{R} \$ 818$ \\
\hline Total & $\mathrm{R} \$ 90.258$ & $\mathrm{R} \$ 46.794$ & $\mathrm{R} \$ 12.859$ & $\mathrm{R} \$ 17.804$ & $\mathrm{R} \$ 10.230$ & $\mathrm{R} \$ 26.440$ \\
\hline \multicolumn{7}{|c|}{ Relação Liquidação / Empenho } \\
\hline & & $93 \%$ & & & $64 \%$ & $91 \%$ \\
\hline
\end{tabular}

Quadro 3.6: Responsabilidade pelos recursos orçamentários federais destinados ao desenvolvimento urbano (Órgão orçamentário) - Empenho e Liquidação. Valores em milhões. Ano referência de valores: 2016. Fonte: Sistema Integrado de Planejamento e Orçamento, Ministério do Planejamento, Desenvolvimento e Gestão do Governo Federal. Elaboração nossa. 


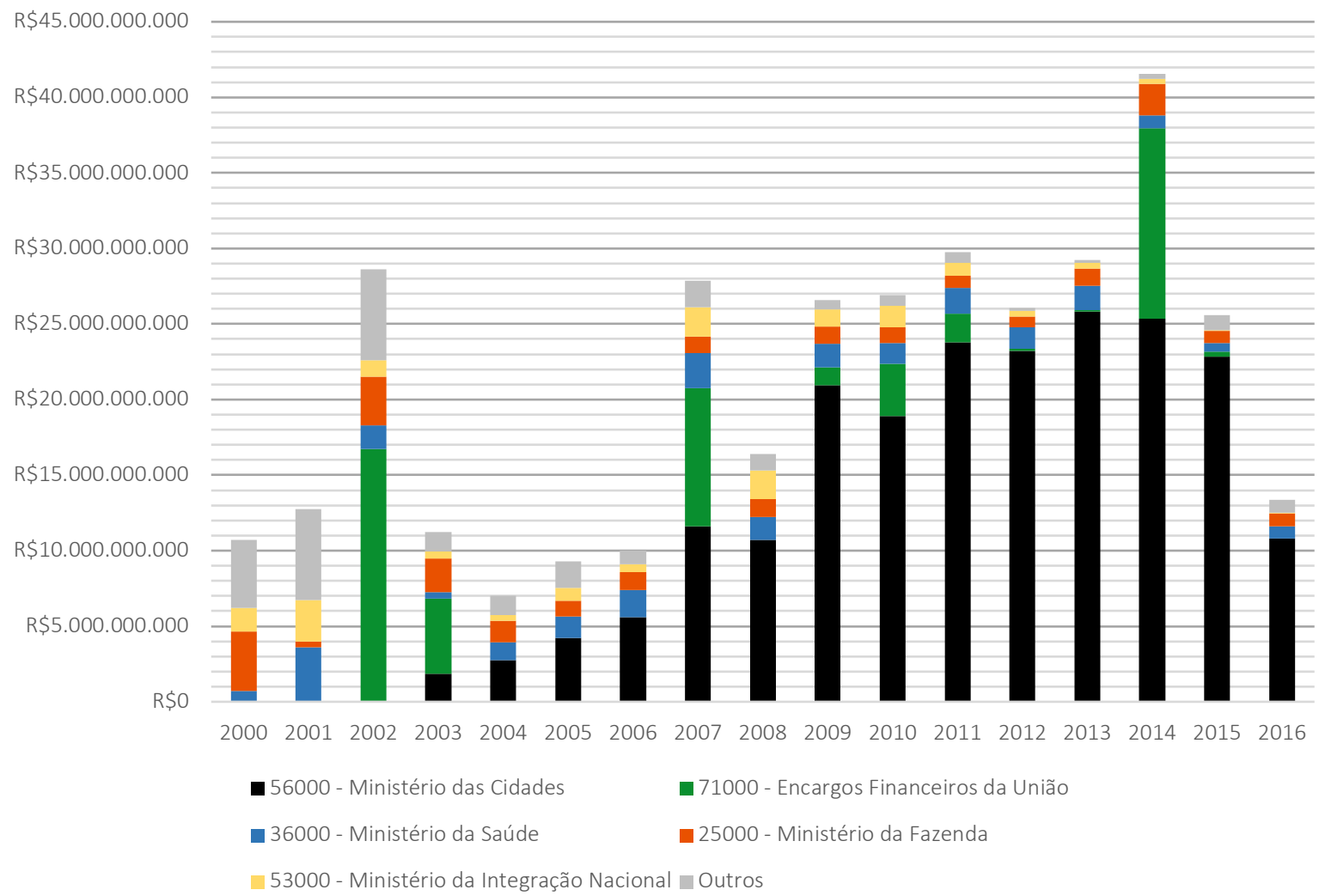

Gráfico 3.6: Responsabilidade pelos recursos orçamentários federais destinados ao desenvolvimento urbano (Órgão orçamentário) - Empenho. Ano referência de valores: 2016. Fonte: Sistema Integrado de Planejamento e Orçamento, Ministério do Planejamento, Desenvolvimento e Gestão do Governo Federal. Elaboração nossa.

A presente seção corrobora a afirmação de que a atuação estatal é elemento de compreensão do desenvolvimento urbano, e os recursos oriundos do Orçamento Geral da União desempenharam um papel, seja em termos de articulação de investimentos, projetos e obras, seja em termos do apoio à política de crédito imobiliário habitacional em forma de subsídio direto à família como alternativa de acesso à casa própria pelos mais pobres, seja em termos da ativação e construção de capacidades e institucionalidades em torno das políticas urbanas e habitacionais e por meio do sistema federativo brasileiro, por exemplo.

Cabe destacar a dimensão que assume esse fenômeno. Os estudos urbanos dedicam importância ao PMCMV. No que se refere ao Orçamento Geral da União, o PMCMV representa cerca de $25 \%$ dos recursos liquidados: quais processos em torno da articulação entre urbano e atuação estatal ainda devem ser considerados? Um balanço coeso e consensual sobre o 
financiamento fiscal do desenvolvimento urbano pode não ser pertinente, uma vez que a produção do espaço também se desdobra em acordo com as estruturas e agentes locais, a exemplo do mercado fundiário, rede de infraestruturas urbanas e habitacionais já existentes, e o acesso a esses, por exemplo. De qualquer modo, é importante frisar que a experiência de construção democrática de políticas urbanas e habitacionais é ainda recente. A continuidade dessas experiências parece fundamental para a qualificação dos processos. Certamente a quantidade de recursos financeiros não determina os resultados finais, mas os recursos financeiros são condição à atuação estatal, e é neste sentido que destacamos a relevância do financiamento fiscal do desenvolvimento urbano.

Se a atuação estatal é relevante à compreensão do urbano, certamente há méritos em estudá-la, também a partir do campo do planejamento urbano e regional. Em acordo com os regulacionistas, a atuação estatal tanto é condição ao regime de acumulação, como é expressão social, também determinada pelas trajetórias econômicas, políticas e históricas. Isso implica reconhecer a complexidade de atuação estatal, tanto relacionada às dinâmicas de regime de acumulação contemporâneo (ou flexível), como em acordo com as instituições historicamente construídas, a exemplo das regulações em torno das finanças públicas.

A presente avaliação trata ainda de iluminar a tensão entre o Estado articulador de investimentos e projetos, condutor de processos econômicos e sociais, em relação ao Estado garantidor da agência privada nacional e internacional, regulador, organizado em torno da concessão da provisão de infraestruturas e serviços. Essa tensão está sempre presente, mas é evidenciada frente à desaceleração econômica nacional, de tal modo que a garantia de continuidade do financiamento fiscal do desenvolvimento urbano no país é diminuta, em especial se considerada a implementação da austeridade fiscal permanente em 2016. A condição atual da atuação estatal, expressa a partir do estudo do financiamento fiscal do desenvolvimento urbano, é um produto histórico, em processo desde os finais da década de 1970, tal como debatido pelo capítulo 1 do presente estudo. Dito disso, como pensar em formas de atuação estatal capazes de enfrentar o problema urbano, solução que passa pela provisão e promoção do acesso universal aos serviços e infraestruturas urbana e habitacional? 


\subsection{Financiamento fiscal por eixos do desenvolvimento urbano}

Compreende-se o financiamento fiscal do desenvolvimento urbano a partir de sete eixos, seis temáticos e um relativo à execução dos recursos orçamentários, as Operações Especiais, tal como apresentado pelo capítulo 2. A presente seção parte da classificação programática adotada em execução orçamentária federal para a composição dos eixos do desenvolvimento urbano. ${ }^{284}$ Estabelecidos os eixos do desenvolvimento urbano, são avaliadas as ações financeiramente mais representativas para cada um desses. ${ }^{285}$

A presente dissertação não pretende, em termos teóricos ou metodológicos, esclarecer os motivos que justificam a alocação de recursos financeiros $X$ ou $Y$ para determinado eixo do desenvolvimento urbano. Avançar neste sentido demandaria o estudo dos processos decisórios que permeiam o orçamento público, também de grande importância e a exemplo do debate apresentado por Peres (2018). De qualquer modo, avaliar o financiamento fiscal por eixos do desenvolvimento é fundamental ao entendimento da materialidade promovida a partir do Orçamento Geral da União: para cada eixo do desenvolvimento urbano são avaliadas as dez ações orçamentárias mais representativas em termos financeiros, o que demonstrar-se-á estratégia satisfatória ao entendimento de universo empírico tão amplo, de R\$204 bilhões liquidados. ${ }^{286}$ As ações orçamentárias são a informação mais detalhada apresentada pela base de dados da execução orçamentária federal, e novos avanços qualitativos demandariam o estudo dos contratos promovidos no âmbito de cada ação orçamentária, por exemplo. A presente seção também subsidia e ilustra o debate construído pela seção seguinte deste trabalho, acerca da expressão territorial do financiamento fiscal do desenvolvimento urbano.

284 A totalidade do recorte empírico é abarcada pelas categorias ou eixos do desenvolvimento urbano. Os Quadro Anexo 2 e Quadro Anexo 3 detalham os eixos do desenvolvimento urbano, estruturados a partir das classificações programáticas federais, e apresentam os valores empenhados e liquidados por ano para cada classificação programática de cada eixo do desenvolvimento urbano.

285 A pertinência de estruturar os eixos do desenvolvimento urbano a partir das classificações programáticas é debatida pelo capítulo 2 da presente dissertação. Não é improvável que uma mesma ação, executada por diferentes programas em diferentes momentos, componha também diferentes eixos do desenvolvimento urbano, o que não acarreta prejuízos ao debate apresentado pela presenta seção. Vale lembrar, o universo empírico é composto por 909 ações, mais de 50.000 rubricas orçamentárias, o que representa desafios à uniformização da execução orçamentária federal a nível de ações.

286 No caso da Habitação, a estratégia contempla 93\% dos recursos liquidados; Saneamento Básico, $77 \%$; Mobilidade Urbana, 68\%; Energia Elétrica, 97\%; Infraestrutura Urbana, 91\%; Planejamento e Gestão Pública, 81\%; Operações Especiais, 98\%. 
Como demonstra a execução do Orçamento Geral da União, a multisetorialidade é uma constante no financiamento fiscal do desenvolvimento urbano (Quadro 3.1.1, Gráfico 3.1.1). No detalhe, dos R\$204 bilhões de reais oriundos do Orçamento Geral da União e liquidados em prol do desenvolvimento urbano entre 2000 e 2016, a maior parte foi destinada à Habitação, $\mathrm{R} \$ 65$ bilhões, cerca de 32\% do total. Na sequência, as Operações Especiais ( $R$ \$47 bilhões, cerca de 23\%), Saneamento Básico (R\$ 28 bilhões, cerca de 14\%), Energia elétrica (R\$26 bilhões, cerca de 13\%), Mobilidade urbana (R\$19 bilhões, cerca de 9\%), Infraestrutura urbana (R\$9 bilhões, cerca de 5\%), Planejamento e gestão pública (R\$7 bilhões, cerca de 4\%).

\begin{tabular}{|c|c|c|c|c|c|c|c|}
\hline \multicolumn{8}{|c|}{ Liquidação dos recursos orçamentários federais por eixo do desenvolvimento urbano } \\
\hline & Habitação & $\begin{array}{l}\text { Saneamento } \\
\text { básico }\end{array}$ & $\begin{array}{l}\text { Mobilidade } \\
\text { urbana }\end{array}$ & $\begin{array}{l}\text { Energia } \\
\text { elétrica }\end{array}$ & $\begin{array}{l}\text { Infraestrutura } \\
\text { urbana }\end{array}$ & $\begin{array}{l}\text { Planejamento } \\
\text { e Gestão }\end{array}$ & $\begin{array}{l}\text { Operações } \\
\text { especiais }\end{array}$ \\
\hline 2000 & $\mathrm{R} \$ 1.160$ & $\mathrm{R} \$ 2.487$ & $R \$ 2.029$ & $\mathrm{R} \$ 241$ & $\mathrm{R} \$ 646$ & $\mathrm{R} \$ 117$ & $\mathrm{R} \$ 4.008$ \\
\hline 2001 & $\mathrm{R} \$ 1.286$ & $R \$ 6.793$ & $\mathrm{R} \$ 1.861$ & $\mathrm{R} \$ 319$ & $\mathrm{R} \$ 1.789$ & $R \$ 102$ & $\mathrm{R} \$ 583$ \\
\hline 2002 & $\mathrm{R} \$ 1.248$ & $R \$ 3.000$ & $\mathrm{R} \$ 1.289$ & $\mathrm{R} \$ 16.995$ & $\mathrm{R} \$ 1.676$ & $\mathrm{R} \$ 105$ & $\mathrm{R} \$ 4.323$ \\
\hline 2003 & $\mathrm{R} \$ 1.236$ & $\mathrm{R} \$ 1.057$ & $\mathrm{R} \$ 815$ & $\mathrm{R} \$ 5.047$ & $\mathrm{R} \$ 1.259$ & $\mathrm{R} \$ 76$ & $\mathrm{R} \$ 1.752$ \\
\hline 2004 & $\mathrm{R} \$ 1.459$ & $R \$ 1.666$ & $\mathrm{R} \$ 1.473$ & $\mathrm{R} \$ 316$ & $\mathrm{R} \$ 586$ & $\mathrm{R} \$ 191$ & $\mathrm{R} \$ 1.342$ \\
\hline 2005 & $\mathrm{R} \$ 1.742$ & $R \$ 2.430$ & $\mathrm{R} \$ 2.027$ & $R \$ 264$ & $\mathrm{R} \$ 1.422$ & $R \$ 320$ & $\mathrm{R} \$ 1.069$ \\
\hline 2006 & $\mathrm{R} \$ 2.379$ & $R \$ 2.436$ & $\mathrm{R} \$ 1.805$ & $\mathrm{R} \$ 225$ & $\mathrm{R} \$ 1.821$ & $\mathrm{R} \$ 273$ & $\mathrm{R} \$ 1.067$ \\
\hline 2007 & $\mathrm{R} \$ 1.185$ & $\mathrm{R} \$ 611$ & $R \$ 1.453$ & $R \$ 225$ & $R \$ 61$ & $\mathrm{R} \$ 344$ & $\mathrm{R} \$ 9.328$ \\
\hline 2008 & $\mathrm{R} \$ 1.583$ & $\mathrm{R} \$ 864$ & $\mathrm{R} \$ 756$ & $\mathrm{R} \$ 218$ & $\mathrm{R} \$ 27$ & $\mathrm{R} \$ 210$ & $R \$ 277$ \\
\hline 2009 & $\mathrm{R} \$ 2.198$ & $\mathrm{R} \$ 1.086$ & $\mathrm{R} \$ 1.032$ & $R \$ 235$ & $\mathrm{R} \$ 12$ & $\mathrm{R} \$ 152$ & $\mathrm{R} \$ 3.742$ \\
\hline 2010 & $\mathrm{R} \$ 1.448$ & $\mathrm{R} \$ 1.245$ & $\mathrm{R} \$ 1.440$ & $R \$ 235$ & $R \$ 25$ & $R \$ 152$ & $R \$ 3.816$ \\
\hline 2011 & $\mathrm{R} \$ 402$ & $\mathrm{R} \$ 1.198$ & $R \$ 1.364$ & $R \$ 247$ & $\mathrm{R} \$ 14$ & $\mathrm{R} \$ 102$ & $\mathrm{R} \$ 962$ \\
\hline 2012 & $\mathrm{R} \$ 3.641$ & $\mathrm{R} \$ 1.440$ & $\mathrm{R} \$ 419$ & $\mathrm{R} \$ 48$ & $\mathrm{R} \$ 0$ & $\mathrm{R} \$ 1.000$ & $\mathrm{R} \$ 616$ \\
\hline 2013 & $\mathrm{R} \$ 8.442$ & $R \$ 693$ & $R \$ 358$ & $\mathrm{R} \$ 122$ & $\mathrm{R} \$ 0$ & $\mathrm{R} \$ 1.061$ & $\mathrm{R} \$ 940$ \\
\hline 2014 & $\mathrm{R} \$ 13.260$ & $\mathrm{R} \$ 436$ & $\mathrm{R} \$ 714$ & $\mathrm{R} \$ 232$ & $\mathrm{R} \$ 0$ & $\mathrm{R} \$ 1.049$ & $\mathrm{R} \$ 12.633$ \\
\hline 2015 & $\mathrm{R} \$ 16.526$ & $\mathrm{R} \$ 321$ & $\mathrm{R} \$ 164$ & $\mathrm{R} \$ 833$ & $\mathrm{R} \$ 0$ & $\mathrm{R} \$ 1.106$ & $\mathrm{R} \$ 788$ \\
\hline 2016 & $R \$ 6.758$ & $\mathrm{R} \$ 600$ & $\mathrm{R} \$ 396$ & $\mathrm{R} \$ 818$ & $\mathrm{R} \$ 0$ & $\mathrm{R} \$ 1.109$ & $\mathrm{R} \$ 0$ \\
\hline Total & $R \$ 65.953$ & $\mathrm{R} \$ 28.361$ & $\mathrm{R} \$ 19.393$ & $R \$ 26.621$ & $\mathrm{R} \$ 9.336$ & $\mathrm{R} \$ 7.472$ & $\mathrm{R} \$ 47.247$ \\
\hline$\%$ & $32 \%$ & $14 \%$ & $9 \%$ & $13 \%$ & $5 \%$ & $4 \%$ & $23 \%$ \\
\hline
\end{tabular}

Quadro 3.1.1: Liquidação dos recursos orçamentários federais por eixo do desenvolvimento urbano. Valores em milhões. Ano referência de valores: 2016. Fonte: Sistema Integrado de Planejamento e Orçamento, Ministério do Planejamento, Desenvolvimento e Gestão do Governo Federal. Elaboração nossa. 
$R \$ 35.000 .000 .000$

$\mathrm{R} \$ 30.000 .000 .000$
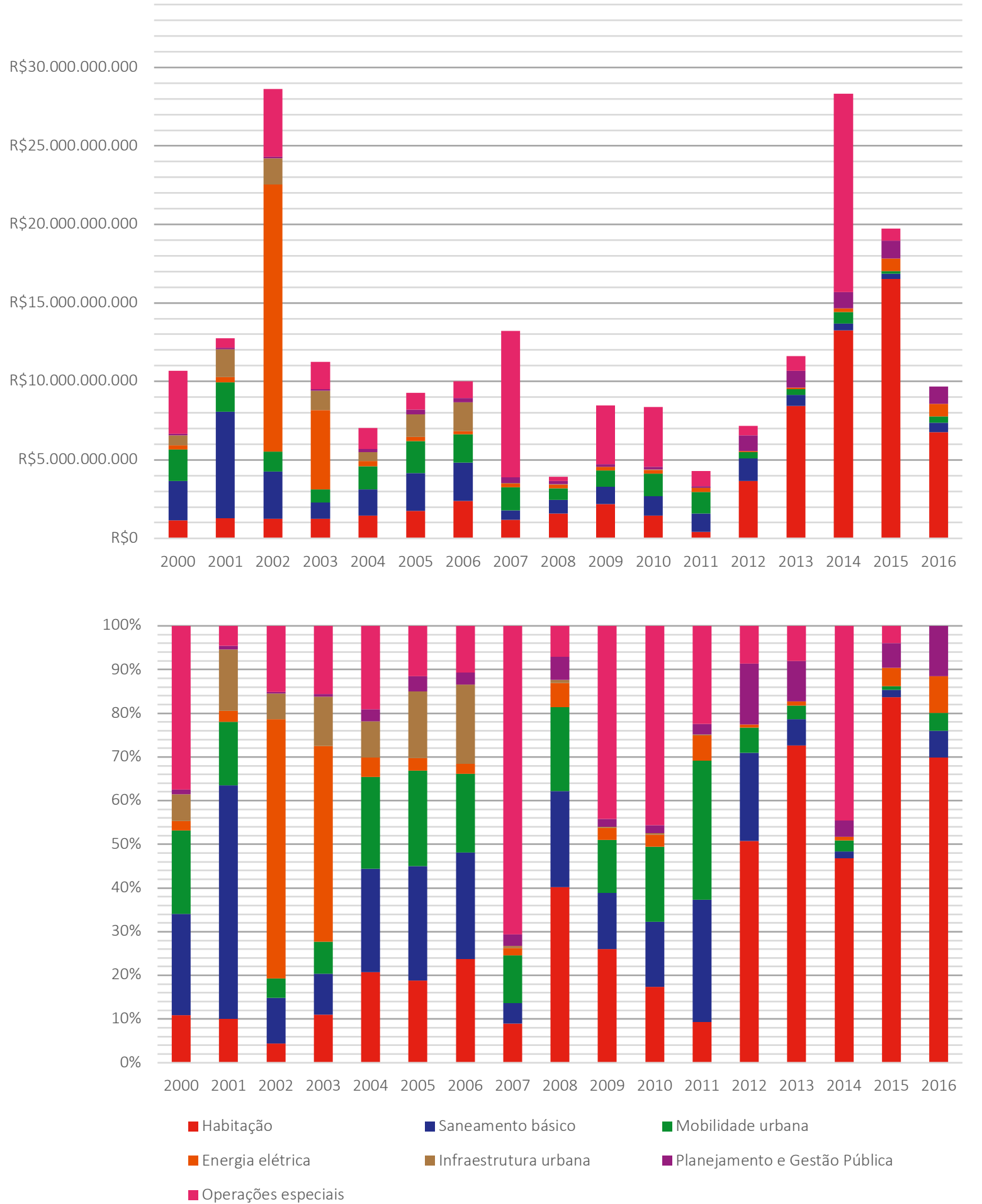

Gráfico 3.1.1: Liquidação dos recursos orçamentários federais por eixo do desenvolvimento urbano - Valores absolutos e relativos por ano. Ano referência de valores: 2016. Fonte: Sistema Integrado de Planejamento e Orçamento, Ministério do Planejamento, Desenvolvimento e Gestão do Governo Federal. Elaboração nossa. 
De modo geral, o financiamento fiscal da Habitação (Quadro 3.1.2) esteve centrado na integralização de cotas e transferências ao Fundo de Arrendamento Residencial (ação 00AF), ${ }^{287}$ com liquidação de recursos concentrada especialmente entre 2012 e 2016, congregando R\$33 bilhões de reais, 50\% do total destinado à habitação. Essa ação, como já debatido, significa o subsídio direto à família com vistas à ampliação do acesso a novas unidades habitacionais no país. As ações $00 C W$ e $00 C X$ também significam o subsídio direto à família com vistas à ampliação do acesso a novas unidades habitacionais, em áreas urbanas ou rurais. ${ }^{288}$ Desse modo, consideradas as dez ações mais representativas no eixo da habitação, três representam o financiamento fiscal do PMCMV. ${ }^{289}$ Os valores totais destinados ao PMCMV já foram debatidos anteriormente pelo presente trabalho. A ação 10S3, a ação 0634, ação 10 5 e ação 0644 significam o apoio à urbanização e melhoria de condições de assentamentos precários e/ou provisão de infraestrutura urbana básica, ${ }^{290}$ que apresentam movimentação financeira a partir de 2004, grande fôlego financeiro em 2006 e entre 2008 e 2010, mas após isso tem sua relevância financeira diminuída, inclusive sem liquidação de recursos em 2015. Essas ações congregam mais de $\mathrm{R} \$ 7$ bilhões de reais. A ação 0703 remonta à Medida Provisório 2.212 de 2001, à Medida Provisória 200 de 2004 e à Lei № 10.998 de 2004, marcos regulatórios do Programa Subsídio à Habitação (PSH), ${ }^{291}$ sendo que a ação concentra liquidação de recursos

${ }^{287}$ OOAF - Integralização de Cotas ao Fundo de Arrendamento Residencial - FAR; OOAF - Transferência ao Fundo de Arrendamento Residencial - FAR.

288 00CW - Subvenção Econômica destinada à implementação de Projetos de Interesse Social em Áreas Urbanas (MP 459, de 2009); 00CW - Subvenção Econômica Destinada a Implementação de Projetos de Interesse Social em Áreas Urbanas (Lei no 11.977, de 2009); 00CX - Subvenção Econômica destinada à implementação de Projetos de Interesse Social em Áreas Rurais (MP 459, de 2009); 00CX - Subvenção Econômica Destinada a Implementação de Projetos de Interesse Social em Áreas Rurais (Lei no 11.977, de 2009).

${ }^{289}$ Apesar da associação ao PMCMV, em termos orçamentários as ações são operadas no âmbito de três classificações programáticas distintas: 0909 - Operações Especiais: Outros Encargos Especiais; 2049 - Moradia Digna; 9991 - Habitação de Interesse Social.

$29010 S 3$ - Apoio à Urbanização de Assentamentos Precários; 0634 - Apoio à Melhoria das Condições de Habitabilidade de Assentamentos Precários; $10 S 5$ - Apoio a Empreendimentos de Saneamento Integrado em Assentamentos Precários em Municípios de Regiões Metropolitanas, de Regiões Integradas de Desenvolvimento Econômico ou Municípios com mais de 150 mil Habitantes; 1055 - Apoio a Empreendimentos de Saneamento Integrado em Municípios com População Superior a 50 mil Habitantes ou Municípios Integrantes de Regiões Metropolitanas ou de Regiões Integradas de Desenvolvimento; $10 S 5$ - Apoio a Empreendimentos de Saneamento Integrado em Regiões Metropolitanas, Regiões Integradas de Desenvolvimento Econômico, Municípios com mais de 50 mil Habitantes ou Integrantes de Consórcios Públicos com mais de 150 mil Habitantes; 0644 - Apoio à Urbanização de Assentamentos Precários (Habitar-Brasil).

${ }^{291} 0703$ - Subsídio à Habitação de Interesse Social (Lei no 10.998, de 2004); 0703 - Subsídio à Habitação de Interesse Social (MP no 2.212, de 2001); 0703 - Subsídio à Habitação de Interesse Social (MP no 200, de 2004). 
entre 2002 e 2008, e significa o financiamento do consumo e da produção de unidades habitacionais ou do parcelamento habitacional, sendo esse recurso operado por agências financeiras, com atenção ao equilíbrio econômico-financeiro na gestão dos recursos, compreendendo a remuneração das despesas de administração e contratação do crédito, à capacidade de pagamento de contratante do financiamento e ampliação do acesso à habitação em relação ao valor de subsídio possível, por exemplo. ${ }^{292}$ A ação 3958 "Melhoria das Condições de Habitabilidade" é abarcada pelo Programa Morar Melhor, com liquidação de recursos entre 2000 e $2003 .{ }^{293}$ A ação 2272 refere-se ao custeio da gestão e administração de uma série de programas federais.

Com o fortalecimento do financiamento fiscal do PMCMV a partir de 2012, as demais iniciativas de financiamento da Habitação no país perdem relevância financeira, e a produção e acesso subsidiado a novas unidades habitacionais se torna a proposta federal predominante. Em um país urbano e autoconstruído, a solução para o problema habitacional vai além da construção de novas unidades, sendo a melhoria habitacional e urbanística uma alternativa importante para as cidades brasileiras, e por isso a importância da urbanização de assentamentos precários, com importância financeira restrita entre 2006 e 2010, principalmente. $^{294}$

292 Lei № 10.998, de 15 de dezembro de 2004: Art. 3o Para os fins desta Lei considera-se: I - financiamento: a operação caracterizada, no mínimo, pelo aporte de recursos financeiros, provenientes das instituições financeiras ou agentes financeiros do SFH participantes do Programa, necessários à composição do pagamento do preço de imóvel residencial, retornáveis pelos beneficiários finais das operações; II - parcelamento: a operação caracterizada, no mínimo, pelo aporte de recursos financeiros, bens ou serviços, provenientes de órgãos e entidades responsáveis pela promoção dos empreendimentos necessários à composição do pagamento do preço de imóvel residencial, passíveis de retorno, parcial ou integral, pelos beneficiários finais das operações.

${ }^{293}$ Em 2003 o Tribunal de Contas da União realizou auditoria sobre o Programa Morar Melhor, então sob responsabilidade da Secretaria Nacional de Habitação, Ministério das Cidades. O documento encontra-se disponível em: <https://www.google.com/url?sa=t\&rct=j\&q=\&esrc=s\&source=web\&cd=1\&ved=2ahUKEwjt4y84MHIAhVEHbkGHYFVDM8QFjAAegQIAhAC\&url=https\%3A\%2F\%2Fportal.tcu.gov.br\%2Flumis\%2Fportal\%2Ffile \%2FfileDownload.jsp\%3Ffileld\%3D8A8182A24F0A728E014F0AE28A346938\&usg=AOvVaw2w_gPjUYSycvZ_y2CIX pNg>, consultado em outubro de 2019.

${ }^{294}$ A política federal de urbanização de assentamentos precários remonta a iniciativas de governos locais e, assim, encontra correspondência em outras políticas sociais, a exemplo do Programa Bolsa Família. 


\begin{tabular}{|c|c|c|c|c|c|c|c|c|c|c|c|}
\hline \multicolumn{12}{|c|}{ Financiamento fiscal da Habitação: Valores liquidados por ação orçamentária } \\
\hline & OOAF & OOCW & 1053 & 0703 & OOCX & 0634 & 3958 & $10 S 5$ & 2272 & 0644 & Outras \\
\hline 2000 & $\mathrm{R} \$-$ & $R \$-$ & $R \$-$ & $R \$-$ & $R \$-$ & $\mathrm{R} \$-$ & $\mathrm{R} \$ 671,2$ & $\mathrm{R} \$-$ & $\mathrm{R} \$-$ & $R \$-$ & $\mathrm{R} \$ 489,3$ \\
\hline 2001 & $\mathrm{R} \$-$ & $R \$-$ & $\mathrm{R} \$-$ & $\mathrm{R} \$-$ & $\mathrm{R} \$-$ & $R \$-$ & $R \$ 587,7$ & $R \$-$ & $R \$-$ & $R \$-$ & $R \$ 698,6$ \\
\hline 2002 & $R \$$ & $R \$-$ & $\mathrm{R} \$-$ & $\mathrm{R} \$ 820,1$ & R\$- & $R \$-$ & $\mathrm{R} \$ 299,9$ & $R \$-$ & $R \$-$ & $R \$-$ & $\mathrm{R} \$ 128,5$ \\
\hline 2003 & $R \$-$ & $R \$-$ & $R \$-$ & $R \$ 622,6$ & $R \$-$ & $\mathrm{R} \$-$ & $\mathrm{R} \$ 177,6$ & $\mathrm{R} \$-$ & $\mathrm{R} \$-$ & $\mathrm{R} \$-$ & $R \$ 435,4$ \\
\hline 2004 & 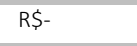 & $R \$-$ & $R \$-$ & $\mathrm{R} \$ 578,7$ & $\mathrm{R} \$-$ & $\mathrm{R} \$ 169,1$ & $\mathrm{R} \$-$ & $R \$-$ & $\mathrm{R} \$ 76,2$ & $\mathrm{R} \$ 361,7$ & $R \$ 273,8$ \\
\hline 2005 & $R \$-$ & $R \$-$ & $R \$-$ & $\mathrm{R} \$ 889,0$ & $R \$-$ & $\mathrm{R} \$ 53,2$ & $\mathrm{R} \$-$ & $\mathrm{R} \$-$ & $R \$ 91,8$ & $\mathrm{R} \$ 231,4$ & $\mathrm{R} \$ 476,5$ \\
\hline 2006 & $\mathrm{R} \$-$ & $R \$-$ & $R \$-$ & $\mathrm{R} \$ 266,0$ & $\mathrm{R} \$-$ & $\mathrm{R} \$ 1.638,9$ & $\mathrm{R} \$-$ & $\mathrm{R} \$-$ & $\mathrm{R} \$ 97,6$ & $R \$ 56,2$ & $R \$ 320,5$ \\
\hline 2007 & $\mathrm{R} \$ 880,6$ & $R \$-$ & $R \$-$ & $\mathrm{R} \$-$ & $R \$-$ & $\mathrm{R} \$ 0,2$ & $R \$-$ & $\mathrm{R} \$-$ & $\mathrm{R} \$ 105,7$ & $R \$ 95,6$ & $R \$ 103,2$ \\
\hline 2008 & $\mathrm{R} \$-$ & $R \$-$ & $\mathrm{R} \$ 794,6$ & $\mathrm{R} \$ 79,6$ & $\mathrm{R} \$-$ & $\mathrm{R} \$-$ & $\mathrm{R} \$-$ & $\mathrm{R} \$ 380,1$ & $\mathrm{R} \$ 106,8$ & $\mathrm{R} \$ 1,1$ & $R \$ 220,8$ \\
\hline 2009 & $\mathrm{R} \$-$ & $R \$-$ & $\mathrm{R} \$ 1.196,0$ & $\mathrm{R} \$-$ & $\mathrm{R} \$-$ & $\mathrm{R} \$-$ & $\mathrm{R} \$-$ & $R \$ 625,9$ & $\mathrm{R} \$ 121,5$ & $\mathrm{R} \$-$ & $R \$ 254,1$ \\
\hline 2010 & $\mathrm{R} \$-$ & $\mathrm{R} \$-$ & $\mathrm{R} \$ 943,0$ & $\mathrm{R} \$-$ & $\mathrm{R} \$-$ & $\mathrm{R} \$-$ & $\mathrm{R} \$-$ & $R \$ 290,2$ & $\mathrm{R} \$ 130,2$ & $R \$-$ & $\mathrm{R} \$ 84,4$ \\
\hline 2011 & $\mathrm{R} \$-$ & $R \$-$ & $\mathrm{R} \$ 149,9$ & $\mathrm{R} \$$ & $\mathrm{R} \$-$ & $\mathrm{R} \$-$ & $\mathrm{R} \$-$ & $\mathrm{R} \$-$ & $\mathrm{R} \$ 123,3$ & $R \$-$ & $\mathrm{R} \$ 128,6$ \\
\hline 2012 & $R \$ 3.006,4$ & $R \$-$ & $R \$ 155,7$ & $\mathrm{R} \$-$ & $R \$ 220,0$ & $\mathrm{R} \$-$ & $\mathrm{R} \$-$ & $\mathrm{R} \$-$ & $\mathrm{R} \$-$ & $R \$-$ & $R \$ 258,5$ \\
\hline 2013 & $\mathrm{R} \$ 7.872,4$ & $R \$-$ & $\mathrm{R} \$ 22,2$ & $R \$-$ & $\mathrm{R} \$ 470,8$ & $R \$-$ & $R \$-$ & $R \$-$ & $R \$-$ & $\mathrm{R} \$-$ & $\mathrm{R} \$ 77,0$ \\
\hline 2014 & $\mathrm{R} \$ 12.276,7$ & $\mathrm{R} \$-$ & $\mathrm{R} \$ 10,9$ & $\mathrm{R} \$$ & $\mathrm{R} \$ 793,7$ & $\mathrm{R} \$-$ & $\mathrm{R} \$-$ & $\mathrm{R} \$-$ & $R \$-$ & $R \$-$ & $\mathrm{R} \$ 178,3$ \\
\hline 2015 & $R \$ 4.768,2$ & $R \$ 11.255,4$ & $\mathrm{R} \$-$ & $R \$-$ & $R \$ 301,3$ & $R \$-$ & $\mathrm{R} \$-$ & $\mathrm{R} \$-$ & $R \$-$ & $R \$-$ & $R \$ 201,1$ \\
\hline 2016 & $\mathrm{R} \$ 4.474,3$ & $\mathrm{R} \$ 918,5$ & $\mathrm{R} \$ 27,9$ & $\mathrm{R} \$-$ & $\mathrm{R} \$ 727,4$ & 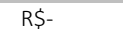 & $\mathrm{RS}-$ & $\mathrm{R} \$-$ & $\mathrm{R} \$-$ & $R \$-$ & $\mathrm{R} \$ 609,5$ \\
\hline Total & $R \$ 33.278,6$ & $\mathrm{R} \$ 12.173,9$ & $\mathrm{R} \$ 3.300,3$ & $\mathrm{R} \$ 3.255,9$ & $\mathrm{R} \$ 2.513,2$ & $\mathrm{R} \$ 1.861,4$ & $\mathrm{R} \$ 1.736,4$ & $\mathrm{R} \$ 1.296,2$ & $\mathrm{R} \$ 853,0$ & $\mathrm{R} \$ 746,1$ & $\mathrm{R} \$ 4.938,2$ \\
\hline$\%$ & $50 \%$ & $18 \%$ & $5 \%$ & $5 \%$ & $4 \%$ & $3 \%$ & $3 \%$ & $2 \%$ & $1 \%$ & $1 \%$ & $7 \%$ \\
\hline
\end{tabular}

Quadro 3.1.2: Financiamento fiscal da Habitação: valores liquidados por ação orçamentária. Valores em milhões. Ano referência de valores: 2016. Fonte: Sistema Integrado de Planejamento e Orçamento, Ministério do Planejamento, Desenvolvimento e Gestão do Governo Federal. Elaboração nossa.

A respeito do financiamento fiscal do Saneamento Básico (Quadro 3.1.3), destaca-se a ação $5528,{ }^{295}$ orientada ao financiamento do saneamento básico, inclusive em pequenas localidades, articulando quase $\mathrm{R} \$ 7$ bilhões de reais entre 2000 e 2006. A ação 3861, ${ }^{296}$ operacionalizada no âmbito dos programas Saneamento Básico, Saneamento Ambiental Urbano e Serviços Urbanos de Água e Esgoto, ${ }^{297}$ está orientada à implantação, ampliação ou melhoria do abastecimento de água, inclusive em municípios de pequeno porte, congregando quase R\$7 bilhões de reais entre 2000 e 2007. Destacam-se ainda os gastos com a construção e recuperação de infraestrutura hídrica (ação 1851), 298 operacionalizados no âmbito dos programas Infraestrutura Hídrica ou Proágua - Infraestrutura hídrica, ${ }^{299}$ por meio de ação que

\footnotetext{
2955528 - Ações de Saneamento Básico em Pequenas Localidades; 5528 - Ações de Saneamento em Pequenas Localidades; 5528 - Saneamento Básico para Controle de Agravos. Operacionalizadas no âmbito dos programas 0119 - Saneamento Básico; 0122 - Saneamento Ambiental Urbano; 0122 - Serviços Urbanos de Água e Esgoto.

2963861 - Implantação, Ampliação ou Melhoria de Sistema Público de Abastecimento de Água para a Prevenção e Controle de Agravos em Municípios de até 30.000 habitantes; 3861 - Construção e Ampliação Ou Melhoria dos Serviços de Abastecimento de Água para Controle de Agravos.

2970119 - Saneamento Básico; 0122 - Saneamento Ambiental Urbano; 0122 - Serviços Urbanos de Água e Esgoto. 2981851 - Construção e Recuperação de Obras de Infra-estrutura Hídrica.

2990515 - Infra-Estrutura Hídrica; 0515 - Proágua - Infra-estrutura. Em acordo com os PPAs 2000, 2004 e 2008, esses programas objetivam (i) 2000: Assegurar a ampliação de oferta de água de boa qualidade para o consumo
} 
congrega mais de R\$5 bilhões, liquidados entre 2000 e 2011, e que visa qualificar a oferta de água de boa qualidade a partir do financiamento de obras estruturantes e prioritárias. As ações 3859 e 3860, 300 por sua vez, promovem a melhoria das condições sanitárias domiciliares e ampliação ou melhoria do sistema de coleta e tratamento de esgoto sanitário, especialmente entre 2000 e 2003. A ação 1845, também operacionalizada entre 2000 e 2003, volta-se às obras de contenção de enchentes. ${ }^{301}$ A ação 1 N08 e a ação 10GE estão direcionadas à ampliação e melhoria de sistema de esgotamento sanitário em municípios com mais de 50 mil habitantes, integrantes ou não integrantes de regiões metropolitanas (RM) ou regiões integradas de desenvolvimento econômico (RIDE). ${ }^{302} 303$ A ação 002L também está direcionada à ampliação e melhoria de sistema de esgotamento sanitário, mas com foco nos municípios com mais de 30 mil habitantes ou integrantes de RM ou RIDE. ${ }^{304}$ Em paralelo a essas, a ação 10SC também foca-

humano e para a produção, por meio da conclusão de obras estruturantes e prioritárias: barragens, açudes e adutoras; (ii) 2004: Aumentar a oferta de água de boa qualidade para o consumo humano e para a produção por meio da execução de obras estruturantes: barragens, açudes e adutoras; (iii) 2008: Desenvolver obras estruturantes de infra-estrutura hídrica para o aumento da oferta de água de boa qualidade.

3003859 - Implantação de Melhorias Sanitárias Domiciliares para Controle de Agravos; 3860 - Construção e Ampliação Ou Melhoria de Sistema de Coleta e Tratamento de Esgoto Sanitário para Controle de Agravos, ambas ações operacionalizadas pelo programa 0119-Saneamento Básico

3011845 - Construção de Obras de Contenção de Enchentes; programa 0515 - Proágua - Infra-estrutura.

302 1N08 - Apoio à Implantação, Ampliação ou Melhorias de Sistemas de Esgotamento Sanitário em Municípios com População Superior a 50 mil Habitantes ou Municípios Integrantes de Regiões Metropolitanas ou de Regiões Integradas de Desenvolvimento; 1N08 - Apoio à Implantação, Ampliação ou Melhorias de Sistemas de Esgotamento Sanitário em Municípios com População Superior a 50 mil Habitantes ou Municípios Integrantes de Regiões Metropolitanas ou de Regiões Integradas de Desenvolvimento; 1N08 - Apoio a Sistemas de Esgotamento Sanitário em Municípios de Regiões Metropolitanas, de Regiões Integradas de Desenvolvimento Econômico, Municípios com mais de 50 mil Habitantes ou Integrantes de Consórcios Públicos com mais de 150 mil Habitantes. Ações operacionalizadas pelos programas 0122 - Serviços Urbanos de Água e Esgoto e 2068 - Saneamento Básico.

${ }^{303}$ 10GE - Implantação e Melhoria de Sistemas Públicos de Esgotamento Sanitário em Municípios de até 50.000 Habitantes ou Integrantes de Consórcios Públicos, Exclusive de Regiões Metropolitanas ou Regiões Integradas de Desenvolvimento Econômico (RIDE); 10GE - Implantação e Melhoria de Sistemas Públicos de Esgotamento Sanitário em Municípios de até 50.000 Habitantes, Exclusive de Regiões Metropolitanas ou Regiões Integradas de Desenvolvimento Econômico (RIDE); 10GE - Implantação, Ampliação e Melhoria de Sistemas Públicos de Esgotamento Sanitário em Municípios com população até 50.000 Habitantes, Exclusive em Regiões Metropolitanas (RM) ou Regiões Integradas de Desenvolvimento Econômico (RIDE). Ações operacionalizadas pelos programas 0122 - Serviços Urbanos de Água e Esgoto e 2068 - Saneamento Básico.

304 002L - Apoio à Implantação e Ampliação de Sistemas de Coleta e Tratamento de Esgotos Sanitários em Municípios com População Superior a 30.000 habitantes; 002L - Apoio à Implantação, Ampliação ou Melhoria de Sistema Público de Esgotamento Sanitário em Municípios Integrantes de Regiões Metropolitanas e Regiões Integradas de Desenvolvimento Econômico (RIDE) para Prevenção e Controle de Doenças. Ações operacionalizadas pelos programas 0122 - Serviços Urbanos de Água e Esgoto e 0122 - Saneamento Ambiental Urbano. 
se sobre municípios com mais de 50 mil habitantes ou integrantes de RM ou RIDE, mas com atenção à ampliação e melhoria de sistema de abastecimento de água. ${ }^{305}$

A respeito do financiamento fiscal do Saneamento Básico, não é observada grande mudança no mérito das ações entre 2000 e 2016, em grande medida orientadas à ampliação e qualificação de sistemas de esgotamento sanitário, abastecimento de água e drenagem urbana, por exemplo. Em geral, as ações com liquidação de recursos entre 2000 e 2007 deixam de ser financiadas, ao passo que as ações 1N08, 10SC e 10GE ganham relevância a partir de 2008, o que significa a liquidação de recursos fiscais em municípios com mais de 30 ou 50 mil habitantes, em geral integrantes de RM ou RIDE, onde concentram-se a precariedade urbanística brasileira e demandas por infraestrutura e serviços de saneamento básico. Evidente, se o objetivo é a universalização do acesso ao saneamento básico, isso não significa dizer que os municípios não priorizados devem estar desassistidos pela atuação federal.

\footnotetext{
305 10SC - Apoio à Implantação, Ampliação ou Melhorias em Sistemas de Abastecimento de Água em Municípios com População Superior a 50 mil Habitantes ou Municípios Integrantes de Regiões Metropolitanas ou de Regiões Integradas de Desenvolvimento; 10SC - Apoio à Implantação, Ampliação ou Melhorias em Sistemas de Abastecimento de Água em Municípios com População Superior a 50 mil Habitantes ou Municípios Integrantes de Regiões Metropolitanas ou de Regiões Integradas de Desenvolvimento; 10SC - Apoio a Sistemas de Abastecimento de Água em Municípios de Regiões Metropolitanas, de Regiões Integradas de Desenvolvimento Econômico, Municípios com mais de 50 mil Habitantes ou Integrantes de Consórcios Públicos com mais de 150 mil Habitantes. Ações operacionalizadas pelos programas 0122 - Serviços Urbanos de Água e Esgoto e 2068 - Saneamento Básico.
} 


\begin{tabular}{|c|c|c|c|c|c|c|c|c|c|c|c|}
\hline \multicolumn{12}{|c|}{ Financiamento fiscal do Saneamento Básico: valores liquidados por ação orçamentária } \\
\hline & 5528 & 3861 & 1851 & 3859 & 3860 & 1845 & 1N08 & $10 \mathrm{SC}$ & 10GE & $002 \mathrm{~L}$ & Outras \\
\hline 2000 & $\mathrm{R} \$ 126,4$ & $\mathrm{R} \$ 202,1$ & $\mathrm{R} \$ 1.133,4$ & $\mathrm{R} \$ 146,4$ & $\mathrm{R} \$ 202,3$ & $\mathrm{R} \$ 277,6$ & $\mathrm{R} \$-$ & $\mathrm{R} \$-$ & $\mathrm{R} \$-$ & $\mathrm{R} \$-$ & $R \$ 398,9$ \\
\hline 2001 & $\mathrm{R} \$ 417,5$ & $\mathrm{R} \$ 1.494,6$ & $\mathrm{R} \$ 1.838,0$ & $\mathrm{R} \$ 964,4$ & $\mathrm{R} \$ 716,9$ & $\mathrm{R} \$ 542,1$ & $R \$-$ & $\mathrm{R} \$-$ & $R \$-$ & $\mathrm{R} \$-$ & $\mathrm{R} \$ 819,0$ \\
\hline 2002 & $\mathrm{R} \$ 137,7$ & $\mathrm{R} \$ 495,2$ & $R \$ 489,4$ & $R \$ 501,1$ & $R \$ 392,2$ & $R \$ 143,7$ & $R \$-$ & $\mathrm{R} \$-$ & $R \$-$ & $\mathrm{RS}-$ & $\mathrm{R} \$ 840,5$ \\
\hline 2003 & $\mathrm{R} \$ 106,4$ & $\mathrm{R} \$ 119,8$ & $\mathrm{R} \$ 122,7$ & $\mathrm{R} \$ 86,3$ & $\mathrm{R} \$ 66,5$ & $\mathrm{R} \$ 100,6$ & $R \$-$ & $R \$-$ & $R \$-$ & $\mathrm{R} \$-$ & $\mathrm{R} \$ 454,9$ \\
\hline 2004 & $\mathrm{R} \$ 2,3$ & $\mathrm{R} \$ 193,7$ & $\mathrm{R} \$ 121,1$ & $\mathrm{R} \$-$ & $\mathrm{R} \$-$ & $\mathrm{R} \$-$ & $R \$-$ & $R \$-$ & $\mathrm{R} \$-$ & $\mathrm{R} \$ 306,4$ & $\mathrm{R} \$ 1.042,0$ \\
\hline 2005 & $R \$ 263,2$ & $R \$ 257,0$ & $\mathrm{R} \$ 110,2$ & $\mathrm{R} \$-$ & $\mathrm{R} \$-$ & $\mathrm{R} \$-$ & $R \$-$ & $\mathrm{R} \$-$ & $R \$-$ & $R \$ 194,4$ & $R \$ 1.605,5$ \\
\hline 2006 & $\mathrm{R} \$ 407,5$ & $R \$ 306,0$ & $R \$ 146,2$ & $R \$-$ & $R \$-$ & $R \$-$ & $R \$-$ & $R \$-$ & $\mathrm{R} \$-$ & $R \$ 209,4$ & $R \$ 1.366,6$ \\
\hline 2007 & $\mathrm{R} \$-$ & $\mathrm{R} \$ 6,5$ & $\mathrm{R} \$ 6,7$ & $R \$-$ & $R \$-$ & $\mathrm{R} \$-$ & $R \$-$ & $\mathrm{R} \$-$ & $R \$ 9,0$ & $\mathrm{R} \$ 0,3$ & $\mathrm{R} \$ 588,5$ \\
\hline 2008 & $R \$-$ & $\mathrm{R} \$-$ & $\mathrm{R} \$ 30,7$ & $R \$-$ & $R \$-$ & $R \$-$ & $\mathrm{R} \$ 173,9$ & $\mathrm{R} \$ 194,7$ & $R \$-$ & $R \$-$ & $\mathrm{R} \$ 464,8$ \\
\hline 2009 & $\mathrm{R} \$-$ & $R \$-$ & $\mathrm{R} \$ 3,0$ & $\mathrm{R} \$-$ & $\mathrm{R} \$-$ & $\mathrm{R} \$-$ & $\mathrm{R} \$ 323,5$ & $R \$ 299,9$ & $R \$ 2,6$ & $\mathrm{R} \$-$ & $\mathrm{R} \$ 456,8$ \\
\hline 2010 & $R \$-$ & $R \$-$ & $\mathrm{R} \$ 7,8$ & $\mathrm{R} \$-$ & $R \$-$ & $\mathrm{R} \$-$ & $\mathrm{R} \$ 276,0$ & $R \$ 137,6$ & $\mathrm{R} \$ 23,0$ & $\mathrm{R} \$-$ & $\mathrm{R} \$ 801,0$ \\
\hline 2011 & $\mathrm{R} \$-$ & $R \$-$ & $\mathrm{R} \$ 0,8$ & $R \$-$ & $R \$-$ & $\mathrm{R} \$-$ & $\mathrm{R} \$ 64,5$ & $\mathrm{R} \$ 154,3$ & $\mathrm{R} \$ 219,7$ & $R \$-$ & $\mathrm{R} \$ 758,3$ \\
\hline 2012 & $R \$-$ & $R \$-$ & $\mathrm{R} \$-$ & $R \$-$ & $\mathrm{R} \$-$ & $\mathrm{R} \$-$ & $R \$ 206,0$ & $R \$ 202,5$ & $\mathrm{R} \$ 430,4$ & $R \$-$ & $\mathrm{R} \$ 601,1$ \\
\hline 2013 & $\mathrm{R} \$-$ & $R \$-$ & $\mathrm{R} \$-$ & $\mathrm{R} \$-$ & $R \$-$ & $\mathrm{RS}-$ & $\mathrm{R} \$ 121,6$ & $\mathrm{R} \$ 75,3$ & $\mathrm{R} \$ 155,0$ & $\mathrm{R} \$-$ & $R \$ 341,2$ \\
\hline 2014 & $R \$-$ & $\mathrm{R} \$-$ & $R \$-$ & $\mathrm{R} \$-$ & $R \$-$ & $\mathrm{R} \$-$ & $\mathrm{R} \$ 38,3$ & $\mathrm{R} \$ 71,9$ & $\mathrm{R} \$ 96,5$ & $R \$-$ & $\mathrm{R} \$ 228,9$ \\
\hline 2015 & $\mathrm{R} \$-$ & $\mathrm{R} \$-$ & $R \$-$ & $R \$-$ & $\mathrm{R} \$-$ & $\mathrm{R} \$-$ & $\mathrm{R} \$ 66,4$ & $\mathrm{R} \$ 41,9$ & $\mathrm{R} \$ 86,8$ & $\mathrm{R} \$-$ & $\mathrm{R} \$ 126,1$ \\
\hline 2016 & $\mathrm{R} \$-$ & $\mathrm{R} \$-$ & $\mathrm{R} \$-$ & $\mathrm{R} \$-$ & $\mathrm{R} \$-$ & $\mathrm{R} \$-$ & $\mathrm{R} \$ 134,4$ & $R \$ 109,9$ & $R \$ 186,8$ & $R \$-$ & $\mathrm{R} \$ 168,5$ \\
\hline Total & $R \$ 6.989,0$ & $R \$ 6.935,9$ & $R \$ 5.860,9$ & $\mathrm{R} \$ 5.557,3$ & $R \$ 5.237,9$ & $R \$ 2.908,9$ & $\mathrm{R} \$ 1.404,4$ & $\mathrm{R} \$ 1.287,9$ & $R \$ 1.209,8$ & $\mathrm{R} \$ 710,4$ & $\mathrm{R} \$ 11.062,7$ \\
\hline$\%$ & $14 \%$ & $14 \%$ & $12 \%$ & $11 \%$ & $11 \%$ & $6 \%$ & $3 \%$ & $3 \%$ & $2 \%$ & $1 \%$ & $23 \%$ \\
\hline
\end{tabular}

Quadro 3.1.3: Financiamento fiscal do Saneamento Básico: valores liquidados por ação orçamentária. Valores em milhões. Ano referência de valores: 2016. Fonte: Sistema Integrado de Planejamento e Orçamento, Ministério do Planejamento, Desenvolvimento e Gestão do Governo Federal. Elaboração nossa.

Referente ao financiamento fiscal da Mobilidade Urbana (Quadro 3.1.4) destaca-se a ação $2843,{ }^{306}$ com liquidação de mais de $R \$ 5$ bilhões de reais entre 2000 e 2011, responsáveis por financiar a operação e manutenção do sistema de transportes ferroviários urbanos de passageiros. Destacam-se ainda a ação $5754,{ }^{307}$ relativa à implantação do sistema de trens urbanos de Recife, Pernambuco; a ação 7L64,308 relativa à expansão e melhoria de malha metroviária de Porto Alegre, Rio Grande do Sul; a ação 5319, ${ }^{309}$ relativa à implantação do sistema de trens urbanos de Fortaleza, Ceará; a ação 5350, ${ }^{310}$ relativa à construção de Rodoanel,

\footnotetext{
3062843 - Funcionamento dos Sistemas de Transporte Ferroviário Urbano de Passageiros; 2843 - Manutenção e Operação dos Sistemas de Transporte Ferroviário de Passageiros, operacionalizadas pelos programas 0222 Transporte Ferroviário Urbano de Passageiros; 1295 - Descentralização dos Sistemas de Transporte Ferroviário Urbano de Passageiros; 2116 - Programa de Gestão e Manutenção do Ministério das Cidades.

3075754 - Implantação do Sistema de Trens Urbanos de Recife; 5754 - Implantação do Sistema de Trens Urbanos de Recife - PE; 5754 - Implantação do Trecho Cajueiro Seco-Tip-Timbi do Sistema de Trens Urbanos de Recife - PE; 5754 - Implantação do Trecho Rodoviária-Camaragibe e Modernização dos Trechos Recife - Jaboatão, Coqueiral Rodoviária e Recife - Cabo do Sistema de Trens Urbanos de Recife - PE; 5754 - Implantação do Trecho Tip-Timbi e Modernização do Trecho Rodoviária-Recife-Cabo do Sistema de Trens Urbanos de Recife - PE.

3087 L64 - Expansão e Melhoria da Malha Metroviária do Sistema de Trens Urbanos de Porto Alegre - RS.

3095319 - Construção do Sistema de Trens Urbanos de Fortaleza; 5319 - Construção do Sistema de Trens Urbanos de Fortaleza - CE; 5319 - Implantação do Trecho Sul do Sistema de Trens Urbanos de Fortaleza - CE; 5319 Implantação do Trecho Sul Vila das Flores-João Felipe do Sistema de Trens Urbanos de Fortaleza.

${ }^{310} 5350$ - BR-381/116/SP- Construção do Rodoanel; 5350 - Construção do Rodoanel - BR-381/116/SP.
} 
rodovia na região metropolitana de São Paulo; a ação 10SS, ${ }^{311}$ relativa ao desenvolvimento de projetos para o transporte público coletivo urbano; a ação 5743, ${ }^{312}$ relativa à duplicação de trechos rodoviários transmetropolitanos; a ação 5366, ${ }^{313}$ relativa à implantação do metrô de Salvador, Bahia; a ação 10SY, ${ }^{314}$ também referente à implantação do sistema de trens urbanos de Fortaleza, Ceará; e a ação 5753, ${ }^{315}$ relativa à implantação de sistemas de trens urbanos de Belo Horizonte, Minas Gerais.

Verifica-se uma política de mobilidade urbana organizada em torno de grandes projetos de infraestrutura de mobilidade de média e alta capacidade, em geral ferroviária ou metroviária, mas também vias expressas destinadas ao deslocamento por meio de veículos automotores. Entre 2013 e 2014 há um aumento dos recursos liquidados em prol da mobilidade urbana, mas esse aumento não é sustentado durante os anos de 2015 e 2016. Neste sentido, a partir da perspectiva do financiamento fiscal, não é pertinente afirmar que as manifestações de junho de 2013 inflexionaram a trajetória dessas políticas. Parte da explicação pode estar na distribuição das competências estatais entre as diferentes esferas federativas, a partir da qual o governo local assume maior responsabilidade sobre o preço e subsídios das tarifas do transporte público coletivo urbano, por exemplo. Importante frisar, grande parte dos recursos fiscais foram destinados à implantação de infraestrutura de mobilidade urbana em capitais-sede do Mundial de Futebol, mas a liquidação de grande parte desses recursos é iniciada antes mesmo da definição do Brasil enquanto sede do mundial em 2007, à exceção do caso de Porto Alegre (7L64) com recursos liquidados a partir de 2008.

\footnotetext{
311 10SS - Apoio a Projetos de Corredores Estruturais de Transporte Coletivo Urbano; 10SS - Apoio a Projetos de Sistemas de Transporte Coletivo Urbano; 10SS - Apoio a Sistemas de Transporte Público Coletivo Urbano.

3125743 - Duplicação de Trechos Rodoviários no Corredor Transmetropolitano.

3135366 - Implantação do Metrô de Salvador; 5366 - Implantação do Metrô de Salvador - BA; 5366 - Implantação do Sistema de Trens Urbanos de Salvador; 5366 - Implantação do Trecho Lapa-Pirajá do Sistema de Trens Urbanos de Salvador - BA.

314 10SY - Apoio à Implantação do Trecho Sul Vila das Flores-João Felipe do Sistema de Trens Urbanos de Fortaleza - CE.

3155753 - Implantação do Sistema de Trens Urbanos de Belo Horizonte; 5753 - Implantação do Sistema de Trens Urbanos de Belo Horizonte - MG.
} 


\begin{tabular}{|c|c|c|c|c|c|c|c|c|c|c|c|}
\hline \multicolumn{12}{|c|}{ Financiamento fiscal da Mobilidade Urbana: valores liquidados por ação orçamentária } \\
\hline & 2843 & 5754 & 7L64 & 5319 & 5350 & $10 S S$ & 5743 & 5366 & $10 S Y$ & 5753 & Outras \\
\hline 2000 & $\mathrm{R} \$ 184,1$ & $R \$ 215,6$ & $\mathrm{R} \$-$ & $\mathrm{R} \$ 341,9$ & $\mathrm{R} \$ 228,3$ & $\mathrm{R} \$-$ & $\mathrm{R} \$ 462,0$ & $R \$ 93,5$ & $\mathrm{R} \$-$ & $\mathrm{R} \$ 175,5$ & $\mathrm{R} \$ 328,1$ \\
\hline 2001 & $R \$ 159,0$ & $\mathrm{R} \$ 348,2$ & $R \$-$ & $\mathrm{R} \$ 233,0$ & $R \$ 265,2$ & $R \$-$ & $\mathrm{R} \$ 147,9$ & $\mathrm{R} \$ 253,8$ & $R \$-$ & $\mathrm{R} \$ 275,6$ & $\mathrm{R} \$ 178,7$ \\
\hline 2002 & $R \$ 206,3$ & $\mathrm{R} \$ 133,0$ & $R \$-$ & $\mathrm{R} \$ 217,5$ & $\mathrm{R} \$ 391,3$ & $R \$-$ & $\mathrm{R} \$ 67,0$ & $\mathrm{R} \$ 98,7$ & $R \$-$ & $\mathrm{R} \$ 89,9$ & $\mathrm{R} \$ 85,0$ \\
\hline 2003 & $R \$ 153,2$ & $\mathrm{R} \$ 75,6$ & $R \$-$ & $\mathrm{R} \$ 18,2$ & $R \$-$ & $R \$-$ & $R \$-$ & $R \$ 37,5$ & $R \$-$ & $R \$ 44,6$ & $\mathrm{R} \$ 486,1$ \\
\hline 2004 & $\mathrm{R} \$ 531,2$ & $\mathrm{R} \$ 112,8$ & $R \$-$ & $R \$ 92,4$ & $\mathrm{R} \$-$ & $\mathrm{R} \$-$ & $\mathrm{R} \$-$ & $\mathrm{R} \$ 89,2$ & $\mathrm{R} \$-$ & $R \$-$ & $\mathrm{R} \$ 647,8$ \\
\hline 2005 & $R \$ 593,0$ & $R \$ 55,0$ & $R \$-$ & $R \$ 50,2$ & $\mathrm{R} \$-$ & $R \$-$ & $R \$-$ & $\mathrm{R} \$ 50,5$ & $R \$-$ & $R \$-$ & $\mathrm{R} \$ 1.277,9$ \\
\hline 2006 & $R \$ 618,2$ & $\mathrm{R} \$ 143,5$ & $R \$-$ & $R \$-$ & $\mathrm{R} \$-$ & $R \$-$ & $\mathrm{R} \$-$ & $\mathrm{R} \$-$ & $R \$-$ & $R \$-$ & $\mathrm{R} \$ 1.043,3$ \\
\hline 2007 & $\mathrm{R} \$ 592,1$ & $\mathrm{R} \$ 9,9$ & $R \$-$ & $R \$-$ & $\mathrm{RS}-$ & $\mathrm{R} \$-$ & $\mathrm{RS}-$ & $\mathrm{RS}-$ & $\mathrm{R} \$-$ & $R \$-$ & $\mathrm{R} \$ 851,1$ \\
\hline 2008 & $R \$ 569,7$ & $\mathrm{R} \$ 8,4$ & $\mathrm{R} \$ 24,6$ & $R \$-$ & $\mathrm{R} \$$ & $\mathrm{R} \$-$ & $\mathrm{R} \$-$ & $\mathrm{R} \$-$ & $R \$-$ & $R \$-$ & $\mathrm{R} \$ 152,8$ \\
\hline 2009 & $R \$ 616,1$ & $\mathrm{R} \$ 4,2$ & $R \$ 275,7$ & $\mathrm{R} \$-$ & $\mathrm{R} \$-$ & $\mathrm{R} \$$ & $\mathrm{R} \$-$ & $\mathrm{R} \$-$ & $\mathrm{R} \$-$ & $R \$-$ & $\mathrm{R} \$ 135,6$ \\
\hline 2010 & $R \$ 680,7$ & $R \$ 3,6$ & $\mathrm{R} \$ 342,6$ & $R \$-$ & $\mathrm{R} \$$ & $R \$-$ & $\mathrm{R} \$-$ & $\mathrm{R} \$$ & $R \$ 253,9$ & $R \$-$ & $\mathrm{R} \$ 158,8$ \\
\hline 2011 & $\mathrm{R} \$ 774,1$ & $\mathrm{R} \$ 0,8$ & $R \$ 250,6$ & $R \$-$ & $R \$-$ & $R \$-$ & $R \$-$ & $R \$-$ & $\mathrm{R} \$ 143,8$ & $R \$-$ & $\mathrm{R} \$ 194,4$ \\
\hline 2012 & $\mathrm{R} \$-$ & $\mathrm{R} \$ 12,2$ & $R \$ 220,2$ & $R \$-$ & $\mathrm{R} \$$ & $R \$ 2,6$ & $R \$-$ & $R \$-$ & $\mathrm{R} \$ 22,6$ & $R \$-$ & $\mathrm{R} \$ 160,9$ \\
\hline 2013 & $R \$-$ & $R \$ 104,2$ & $R \$-$ & $R \$-$ & $R \$-$ & $\mathrm{R} \$ 73,6$ & $\mathrm{R} \$-$ & $R \$-$ & $\mathrm{R} \$ 42,9$ & $R \$-$ & $R \$ 137,4$ \\
\hline 2014 & $R \$-$ & $\mathrm{R} \$ 3,3$ & $\mathrm{R} \$-$ & $\mathrm{R} \$-$ & R\$- & $\mathrm{R} \$ 496,6$ & $\mathrm{R} \$-$ & $R \$-$ & $\mathrm{R} \$ 127,7$ & $R \$-$ & $\mathrm{R} \$ 86,9$ \\
\hline 2015 & $R \$-$ & $\mathrm{R} \$-$ & $R \$-$ & $\mathrm{R} \$-$ & $R \$-$ & $\mathrm{R} \$ 76,2$ & $\mathrm{R} \$-$ & $\mathrm{R} \$-$ & $\mathrm{R} \$-$ & $R \$-$ & $\mathrm{R} \$ 87,7$ \\
\hline 2016 & $\mathrm{R} \$-$ & $\mathrm{R} \$ 0,0$ & $\mathrm{R} \$-$ & $\mathrm{R} \$-$ & $\mathrm{R} \$-$ & $R \$ 221,3$ & $\mathrm{R} \$-$ & $\mathrm{R} \$-$ & $\mathrm{R} \$-$ & $\mathrm{R} \$-$ & $\mathrm{R} \$ 174,2$ \\
\hline Total & $\mathrm{R} \$ 5.677,8$ & $\mathrm{R} \$ 1.230,3$ & $\mathrm{R} \$ 1.113,7$ & $\mathrm{R} \$ 953,2$ & $\mathrm{R} \$ 884,8$ & $\mathrm{R} \$ 870,4$ & $\mathrm{R} \$ 676,9$ & $\mathrm{R} \$ 623,1$ & $\mathrm{R} \$ 590,9$ & $\mathrm{R} \$ 585,6$ & $\mathrm{R} \$ 6.186,7$ \\
\hline$\%$ & $29 \%$ & $6 \%$ & $6 \%$ & $5 \%$ & $5 \%$ & $4 \%$ & $3 \%$ & $3 \%$ & $3 \%$ & $3 \%$ & $32 \%$ \\
\hline
\end{tabular}

Quadro 3.1.4: Financiamento fiscal da Mobilidade Urbana: valores liquidados por ação orçamentária. Valores em milhões. Ano referência de valores: 2016. Fonte: Sistema Integrado de Planejamento e Orçamento, Ministério do Planejamento, Desenvolvimento e Gestão do Governo Federal. Elaboração nossa.

Pertinente ao financiamento fiscal da Energia Elétrica (Quadro 3.1.5) destaca-se a ação 0358, ${ }^{316}$ que condensa mais de $\mathrm{R} \$ 16$ bilhões de reais, todos liquidados no ano de 2002. Isso explica a exceção do ano de 2002, exceção em termos de recursos liquidados, exceção debatida no início do capítulo 3. Essa liquidação de recursos, operacionalizada pela ação 0358, encontra sustentação na Medida Provisória № 59 de 2002 que, segundo referida exposição de motivos apresentada pela Casa Civil, busca "[...] conceder financiamento às concessionárias de serviços públicos de distribuição de energia elétrica e às empresas que detenham contratos de compra e venda de energia elétrica. Esse apoio financeiro é cabível tanto como medida preventiva - em face da ameaça de generalização da inadimplência entre os agentes, [...] quanto por seus efeitos sobre os índices de inflação, decorrentes do repasse às tarifas de energia elétrica dos altos custos dos financiamentos que estas empresas teriam de incorrer para suportar esses investimentos". 317

\footnotetext{
${ }^{316} 0358$ - Financiamento ao BNDES para atendimento de ações voltadas ao Setor Elétrico (MP № 59, de 2002). 317 Exposição de motivos de Medida Provisória № 59 de 2002. Disponível em: <http://www.planalto.gov.br/ccivil_03/Exm/2002/203-MF-02.htm>, consultado em outubro de 2019.
} 
É possível apreender, para além das justificativas contábeis e econômicas, os esforços federais para a superação da crise do apagão de 2001, por meio da operacionalização de recursos orçamentários e financiamentos administrados pelo BNDES. Ainda, destaca-se a ação 0874, ${ }^{318}$ lastreada na Medida Provisória № 127 de 2003, que visa a "[...] criação, no âmbito do Banco Nacional de Desenvolvimento Econômico e Social - BNDES, de programa de apoio emergencial e excepcional às concessionárias de serviços públicos de distribuição de energia elétrica $[\ldots]^{\prime \prime}{ }^{319}$

As ações 0358 e 0874 apresentaram uma resposta à crise do apagão no país, também por meio da liquidação de recursos orçamentários e sua operação pelo BNDES, com foco nas concessionárias de serviços públicos de distribuição de energia elétrica. Associadas, essas ações superam a marca dos $\mathrm{R} \$ 20$ bilhões de reais, mais de $80 \%$ dos recursos totais destinados ao financiamento fiscal da energia elétrica entre 2000 e 2016.

Ainda de relevância, destaca-se a ação 00NY, 320 na esteira das medidas emergenciais relativas ao setor de energia elétrica, lastreada na Lei Federal № 10.438 de 2002 que trata da “[...] expansão da oferta de energia elétrica emergencial, recomposição tarifária extraordinária, cria o Programa de Incentivo às Fontes Alternativas de Energia Elétrica (Proinfa), a Conta de Desenvolvimento Energético (CDE), dispõe sobre a universalização do serviço público de energia elétrica $[\ldots]^{\prime \prime}{ }^{321}$

${ }^{318} 0874$ - Financiamento no âmbito do Programa Emergencial de Apoio às Concessionárias de Serviços Públicos de Distribuição de Energia Elétrica (MP no 127, de 2003).

319 "Encaminhamos à consideração de Vossa Excelência, proposta de Edição de Medida Provisória, objetivando a criação, no âmbito do Banco Nacional de Desenvolvimento Econômico e Social - BNDES, de programa de apoio emergencial e excepcional às concessionárias de serviços públicos de distribuição de energia elétrica, destinado a suprir a insuficiência de recursos decorrentes do adiamento da compensação do saldo da Conta de Compensação de Variação de Valores de Itens da "Parcela A" - CVA, estabelecido no art. 1o da Portaria Interministerial no 116, de 04 de abril de 2003, dos Ministros de Estado da Fazenda e de Minas e Energia, para os reajustes e revisões tarifárias que ocorrerem entre 8 de abril de 2003 e 7 de abril de 2004, conforme previsto nos contratos celebrados entre o Poder Concedente e os Concessionários Públicos de energia elétrica". Exposição de motivos de Medida Provisória № 127 de 2003. Disponível em: <http://www.planalto.gov.br/ccivil_03/Exm/2003/EMI151-MF-MMEMDIC-03.htm>, consultado em outubro de 2019.

${ }^{320}$ 00NY - Transferência de Recursos para a Conta de Desenvolvimento Energético (Lei no 10.438, de 26 de abril de 2002).

${ }^{321} \mathrm{Na}$ íntegra: "Dispõe sobre a expansão da oferta de energia elétrica emergencial, recomposição tarifária extraordinária, cria o Programa de Incentivo às Fontes Alternativas de Energia Elétrica (Proinfa), a Conta de Desenvolvimento Energético (CDE), dispõe sobre a universalização do serviço público de energia elétrica, dá nova redação às Leis no 9.427, de 26 de dezembro de 1996, ํㅡ 9.648, de 27 de maio de 1998, ํㅡ 3.890-A, de 25 de abril 
De modo secundário, destaca-se a ação 2272,322 responsável por operacionalizar o custeio da gestão e administração de programas federais. As ações 4880, 323 2993, ${ }^{324} 1437,{ }^{325}$ $2404^{326}$ e $09 \mathrm{HB}^{327}$ tratam de articular a fiscalização de energia elétrica, operar e manter o sistema de ouvidoria e serviços da Agência Nacional de Energia Elétrica, promover campanha educativa sobre o consumo de energia elétrica e fiscalizar as concessionárias de distribuição de energia elétrica. Apenas a $1379^{328}$ está diretamente associada à ampliação do acesso a energia elétrica no país, ação que congrega cerca de 300 milhões de reais liquidados entre 2000 e 2015.

A infraestrutura e serviços de energia elétrica no país estão organizados por meio de concessões, com forte atuação de agentes privados neste setor. Ao Estado, aqui entendido a partir do Orçamento Geral da União, cabe o papel de regulador, fiscalizador e garantidor do setor. Dentre os serviços urbanos básicos, o acesso à energia elétrica é quase universal, destacando-se de todos os demais. As correlações, no entanto, devem ser cuidadosas. Se o acesso a energia elétrica é quase universal, também a provisão dessa infraestrutura é muito menos dificultosa, se comparada à provisão de um sistema integrado de saneamento básico ou mobilidade urbana, por exemplo.

de 1961, no 5.655, de 20 de maio de 1971, no 5.899, de 5 de julho de 1973, ํo 9.991, de 24 de julho de 2000, e dá outras providências." Disponível em: <http://www.planalto.gov.br/ccivil_03/LEIS/2002/L10438.htm>, consultado em outubro de 2019.

3222272 - Gestão e Administração do Programa.

3234880 - Fiscalização dos Serviços de Energia Elétrica.

3242993 - Operação e Manutenção do Sistema de Ouvidoria; 2993 - Ouvidoria da Agência Nacional de Energia Elétrica; 2993 - Ouvidoria Setorial da Agência Nacional de Energia Elétrica.

3251437 - Campanha Educativa Sobre Direitos e Deveres dos Consumidores de Energia Elétrica.

${ }^{326} 2404$ - Fiscalização das Concessionárias de Distribuição de Energia Elétrica.

327 09HB - Contribuição da União para o Custeio do Regime de Previdência dos Servidores Públicos Federais; 09HB - Contribuição da União, de suas Autarquias e Fundações para o Custeio do Regime de Previdência dos Servidores Públicos Federais; 09HB - Contribuição da União, de suas Autarquias e Fundações para o Custeio do Regime de Previdência dos Servidores Públicos Federais.

3281379 - Atendimento das Demandas por Energia Elétrica em Comunidades Não -supridas; 1379 - Atendimento das Demandas por Energia Elétrica em Localidades Isoladas Não Supridas Pela Rede Elétrica Convencional; 1379 Atendimento das Demandas por Energia Elétrica em Localidades Isoladas Não-Supridas pela Rede Elétrica Convencional; 1379 - Atendimento das Demandas por Energia Elétrica em Localidades Isoladas Não-Supridas pela Rede Elétrica Convencional (PRODEEM). 


\begin{tabular}{|c|c|c|c|c|c|c|c|c|c|c|c|}
\hline \multicolumn{12}{|c|}{ Financiamento fiscal da Energia elétrica: valores liquidados por ação orçamentária } \\
\hline & 0358 & 0874 & OONY & 2272 & 4880 & 1379 & 2993 & 1437 & 2404 & 09HB & Outras \\
\hline 2000 & $\mathrm{R} \$-$ & $\mathrm{R} \$-$ & $\mathrm{R} \$-$ & $\mathrm{R} \$-$ & $\mathrm{R} \$-$ & $\mathrm{R} \$ 45,0$ & $\mathrm{R} \$-$ & $R \$ 16,0$ & $\mathrm{R} \$ 51,1$ & $\mathrm{R} \$-$ & $\mathrm{R} \$ 129,0$ \\
\hline 2001 & $\mathrm{R} \$-$ & $R \$-$ & $R \$-$ & $R \$-$ & $R \$-$ & $R \$ 114,7$ & $R \$-$ & $R \$ 69,7$ & $\mathrm{R} \$ 51,0$ & $R \$-$ & $\mathrm{R} \$ 83,9$ \\
\hline 2002 & $\mathrm{R} \$ 16.733,4$ & $\mathrm{R} \$-$ & $R \$-$ & $R \$-$ & $R \$-$ & $\mathrm{R} \$ 68,8$ & $R \$ 34,0$ & $\mathrm{R} \$ 42,0$ & $\mathrm{R} \$ 29,3$ & $R \$-$ & $\mathrm{R} \$ 87,8$ \\
\hline 2003 & $R \$-$ & $\mathrm{R} \$ 4.952,5$ & $R \$-$ & $\mathrm{R} \$-$ & $R \$-$ & $R \$ 14,4$ & $R \$ 25,0$ & $\mathrm{R} \$ 7,0$ & $R \$-$ & $R \$-$ & $R \$ 48,3$ \\
\hline 2004 & $R \$-$ & $\mathrm{R} \$-$ & $R \$-$ & $R \$ 145,5$ & $R \$ 24,6$ & $R \$ 31,2$ & $R \$ 20,7$ & $\mathrm{R} \$-$ & $R \$-$ & $R \$-$ & $R \$ 93,9$ \\
\hline 2005 & $R \$-$ & $\mathrm{R} \$-$ & $R \$-$ & $\mathrm{R} \$ 138,3$ & $\mathrm{R} \$ 40,8$ & $\mathrm{R} \$ 21,8$ & $\mathrm{R} \$ 19,0$ & $R \$-$ & $R \$-$ & $R \$-$ & $R \$ 43,9$ \\
\hline 2006 & $R \$-$ & $R \$-$ & $R \$-$ & $\mathrm{R} \$ 129,4$ & $\mathrm{R} \$ 33,4$ & $\mathrm{R} \$ 9,1$ & $\mathrm{R} \$ 18,5$ & R\$- & $R \$-$ & $R \$ 4,5$ & $R \$ 30,3$ \\
\hline 2007 & $R \$-$ & $R \$-$ & $R \$-$ & $R \$ 120,5$ & $\mathrm{R} \$ 27,7$ & $\mathrm{R} \$ 6,7$ & $R \$ 16,6$ & $R \$-$ & $R \$-$ & $R \$ 11,0$ & $R \$ 42,2$ \\
\hline 2008 & $R \$-$ & $R \$-$ & $R \$-$ & $\mathrm{R} \$ 131,8$ & $R \$ 25,0$ & $R \$ 13,2$ & $R \$ 13,8$ & $R \$-$ & $R \$-$ & $R \$ 16,0$ & $R \$ 18,0$ \\
\hline 2009 & $R \$-$ & $R \$-$ & $R \$-$ & $\mathrm{R} \$ 142,7$ & $\mathrm{R} \$ 20,8$ & $\mathrm{R} \$ 4,8$ & $\mathrm{R} \$ 12,0$ & $R \$-$ & $R \$-$ & $R \$ 21,0$ & $R \$ 33,7$ \\
\hline 2010 & $R \$-$ & $R \$-$ & $R \$-$ & $\mathrm{R} \$ 158,8$ & $\mathrm{R} \$ 21,8$ & $\mathrm{R} \$-$ & $R \$ 14,4$ & $\mathrm{R} \$-$ & $R \$-$ & $R \$ 21,5$ & $\mathrm{R} \$ 18,6$ \\
\hline 2011 & $R \$-$ & $R \$-$ & $R \$-$ & $R \$ 161,5$ & $\mathrm{R} \$ 29,4$ & $\mathrm{R} \$-$ & $R \$ 14,6$ & $R \$-$ & $\mathrm{R} \$-$ & $R \$ 24,6$ & $R \$ 16,5$ \\
\hline 2013 & $R \$-$ & $R \$-$ & $\mathrm{R} \$-$ & $\mathrm{R} \$-$ & $\mathrm{R} \$ 24,4$ & $\mathrm{R} \$ 0,0$ & $R \$ 13,3$ & $R \$-$ & $R \$-$ & $\mathrm{R} \$-$ & $R \$ 83,8$ \\
\hline 2014 & $R \$-$ & $R \$-$ & $R \$ 184,4$ & $R \$-$ & $\mathrm{R} \$ 20,8$ & $\mathrm{R} \$ 0,0$ & $R \$ 12,5$ & $R \$-$ & $R \$-$ & $R \$-$ & $R \$ 14,5$ \\
\hline 2015 & $R \$-$ & $R \$-$ & $R \$ 782,7$ & $R \$-$ & $\mathrm{R} \$ 16,2$ & $\mathrm{R} \$ 0,0$ & $\mathrm{R} \$ 18,8$ & $R \$-$ & $R \$-$ & $R \$-$ & $R \$ 15,6$ \\
\hline 2016 & $\mathrm{R} \$-$ & $\mathrm{R} \$-$ & $\mathrm{R} \$ 773,4$ & $\mathrm{R} \$-$ & $\mathrm{R} \$ 20,6$ & $\mathrm{R} \$-$ & $\mathrm{R} \$ 16,6$ & $\mathrm{R} \$-$ & $\mathrm{R} \$-$ & $\mathrm{R} \$-$ & $\mathrm{R} \$ 7,7$ \\
\hline Total & $\mathrm{R} \$ 16.733,4$ & $\mathrm{R} \$ 4.952,5$ & $\mathrm{R} \$ 1.740,6$ & $\mathrm{R} \$ 1.128,5$ & $\mathrm{R} \$ 330,7$ & $\mathrm{R} \$ 329,9$ & $\mathrm{R} \$ 264,0$ & $\mathrm{R} \$ 134,7$ & $\mathrm{R} \$ 131,4$ & $\mathrm{R} \$ 98,7$ & $\mathrm{R} \$ 776,6$ \\
\hline$\%$ & $63 \%$ & $19 \%$ & $7 \%$ & $4 \%$ & $1 \%$ & $1 \%$ & $1 \%$ & $1 \%$ & $0 \%$ & $0 \%$ & $3 \%$ \\
\hline
\end{tabular}

Quadro 3.1.5: Financiamento fiscal da Energia elétrica: valores liquidados por ação orçamentária. Valores em milhões. Ano referência de valores: 2016. Fonte: Sistema Integrado de Planejamento e Orçamento, Ministério do Planejamento, Desenvolvimento e Gestão do Governo Federal. Elaboração nossa.

O eixo do desenvolvimento urbano aqui denominado Infraestrutura Urbana abarca programas que contribuem ao financiamento das infraestruturas urbanas e habitacionais no Brasil, mas o produto dessa atuação não é exatamente a promoção de uma política de habitação, de saneamento básico, de mobilidade urbana, de energia elétrica ou de financiamento do planejamento e gestão urbana. Mesmo que não incorporado pelas categorias mencionadas, o financiamento fiscal da Infraestrutura Urbana pode se relacionar aos diversos eixos do desenvolvimento urbano: o asfaltamento de uma via urbana, por exemplo, pode estar associado à melhoria da mobilidade urbana, até mesmo ao acesso à educação e saúde pública, por exemplo; um centro histórico urbanamente qualificado, com passeio e iluminação pública adequados, podem significar benefícios turísticos ou ao cotidiano urbano, por exemplo.

O objetivo apresentado pelo PPA 2004 ao programa 6002- Apoio ao Desenvolvimento Urbano de Municípios de Médio e Grande Porte ilustra o debate: “o objetivo desse programa é apoiar a implantação e/ou adequação de recursos de infraestrutura urbana que contribuam para a qualidade de vida da população por meio de obras ou ações que não se enquadrem nas 
ações típicas de outros programas". Os quadros em anexo detalham os demais programas incorporados pelo eixo Infraestrutura Urbana.

As ações mais representativas no financiamento fiscal da Infraestrutura Urbana (Quadro 3.1.6) são operacionalizadas no âmbito de cinco programas. As ações 1920,,329 $1951^{330}$ e $3178^{331}$ são operacionalizadas no âmbito do programa 0805, e essas ações articulam mais de $\mathrm{R} \$ 3$ bilhões de reais. De modo geral, essas ações tratam de implementar ou qualificar a infraestrutura urbana, a exemplo de vias urbanas. A ação 109A 332 é operacionalizada no âmbito do programa 6001, a ação congrega mais de $\mathrm{R} \$ 2,5$ bilhões de reais, e trata de implementar ou qualificar a infraestrutura urbana em municípios com até 100.000 habitantes. As ações 0544,333 $0001,{ }^{334} 0175,{ }^{335}$ e $0402^{336}$ são operacionalizadas no âmbito do programa 0803, e essas ações correspondem à liquidação de mais de $\mathrm{R} \$ 1,5$ bilhão entre 2000 e 2003. Como um todo, a execução orçamentária do programa 0803 aponta para a articulação entre a esfera federal e organismos multilaterais internacionais com vistas à captação de financiamentos, qualificação técnica e desenvolvimento de estratégias de atuação estatal, inclusive em torno de parcerias

\footnotetext{
3291920 - Implantação, Ampliação Ou Melhoria de Obras de Infra-estrutura Urbana, operacionalizada no âmbito do programa 0805 - Infra-estrutura Urbana.

3301951 - Ações de Reestruturação Urbana, Interligação de Áreas Urbanas e de Adequação de Vias, operacionalizada no âmbito do programa 0805 - Infra-estrutura Urbana.

3313178 - Ações Integradas de Desenvolvimento Urbano, ação operacionalizada no âmbito do programa 0122 Saneamento É Vida; 0805 - Infra-estrutura Urbana.

332 109A - Implantação ou Melhoria de Obras de Infra-estrutura Urbana em Municípios com até 100.000 Habitantes, ação operacionalizada no âmbito do programa 6001 - Apoio ao Desenvolvimento Urbano de Municípios; 6001 - Apoio ao Desenvolvimento Urbano de Municípios de Pequeno Porte. De acordo com o PPA 2004, o objetivo do programa 6001 é apoiar a adequação urbana por meio da adequação de recursos de infraestrutura urbana que contribuam para a qualidade de vida da população, inclusive adequação de vias para sistemas motorizados e não-motorizados.

${ }^{333} 0544$ - Integralização de Cotas da Associação Internacional de Desenvolvimento - AID, ação operacionalizada no âmbito do programa 0803 - Recursos para o Desenvolvimento. De acordo com o PPA 2004, o programa 0803 objetiva manter e ampliar as fontes de recursos para financiamento de programas e de outras oportunidades de investimentos a eles associados e monitorar a sua utilização.

3340001 - Integralização de Cotas da Corporação Andina de Fomento - CAF, ação operacionalizada no âmbito do programa 0803 - Recursos para o Desenvolvimento.

3350175 - Promoção do Desenvolvimento do Estado do Tocantins, ação operacionalizada no âmbito do programa 0803 - Recursos para o Desenvolvimento.

${ }^{336} 0402$ - Integralização de Cotas ao Banco Interamericano de Desenvolvimento - Bid, operacionalizada no âmbito do programa 0803 - Recursos para o Desenvolvimento.
} 
público-privadas, por exemplo. ${ }^{337}$ A ação $109 B^{338}$ está direcionada a municípios de médio e grande porte, e a ação $5538^{339}$ à preservação de patrimônio histórico urbano.

\begin{tabular}{|c|c|c|c|c|c|c|c|c|c|c|c|}
\hline \multicolumn{12}{|c|}{ Financiamento fiscal da Infraestrutura urbana: valores liquidados por ação orçamentária } \\
\hline & $109 \mathrm{~A}$ & 1920 & 109B & 0544 & 1951 & 0001 & 3178 & 5538 & 0175 & 0402 & Outras \\
\hline 2000 & $R \$-$ & $R \$ 236,4$ & $\mathrm{R} \$-$ & R\$- & $\mathrm{R} \$ 54,1$ & RS- & $R \$ 100,3$ & $\mathrm{R} \$ 9,8$ & $R \$-$ & $R \$ 70,6$ & $\mathrm{R} \$ 174,8$ \\
\hline 2001 & $\mathrm{R} \$-$ & $\mathrm{R} \$ 709,2$ & $R \$-$ & R\$- & $R \$ 333,2$ & $R \$ 120,8$ & $\mathrm{R} \$ 165,8$ & $\mathrm{R} \$ 22,8$ & $R \$ 259,9$ & $R \$ 62,4$ & $\mathrm{R} \$ 114,5$ \\
\hline 2002 & $\mathrm{R} \$-$ & $\mathrm{R} \$ 851,3$ & $R \$-$ & $R \$ 383,2$ & $R \$ 128,0$ & $R \$ 36,9$ & $R \$ 64,9$ & $R \$ 26,2$ & $R \$-$ & $\mathrm{R} \$ 41,7$ & $R \$ 143,3$ \\
\hline 2003 & $\mathrm{R} \$$ - & $R \$ 403,4$ & $\mathrm{R} \$-$ & $R \$ 375,4$ & $R \$ 35,2$ & $R \$ 182,8$ & RS- & $\mathrm{R} \$ 28,4$ & RS- & $\mathrm{R} \$ 38,8$ & $R \$ 194,8$ \\
\hline 2004 & $R \$ 318,2$ & $\mathrm{R} \$$ - & $R \$ 152,5$ & $R \$-$ & $R S-$ & $R S-$ & 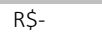 & $R \$ 30,0$ & $R \$-$ & RS\$- & $R \$ 84,8$ \\
\hline 2005 & $R \$ 998,9$ & $R \$-$ & $\mathrm{R} \$ 325,1$ & $\mathrm{R} \$$ - & $\mathrm{R} \$-$ & 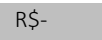 & $\mathrm{R} \$-$ & $\mathrm{R} \$ 48,4$ & $R \$-$ & $R \$-$ & $R \$ 49,5$ \\
\hline 2006 & $\mathrm{R} \$ 1.226,3$ & $R S-$ & $\mathrm{R} \$ 469,1$ & $R \$-$ & $R S-$ & $R S-$ & $R \$-$ & $\mathrm{R} \$ 82,8$ & $R \$-$ & R\$- & $R \$ 42,9$ \\
\hline 2007 & $\mathrm{R} \$ 9,1$ & $R \$-$ & $R \$ 2,3$ & $\mathrm{R} \$$ - & $R \$-$ & $R \$-$ & RS- & $\mathrm{R} \$ 33,5$ & $R \$-$ & R\$- & $R \$ 16,3$ \\
\hline 2008 & $R \$ 1,8$ & $R \$-$ & $R S-$ & $R \$-$ & $R S-$ & $R S-$ & $R \$-$ & $\mathrm{R} \$ 11,8$ & $R \$-$ & $R \$-$ & $R \$ 12,9$ \\
\hline 2009 & $R \$-$ & $R \$-$ & $R \$-$ & $\mathrm{R} \$$ - & $R \$-$ & $R \$-$ & 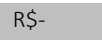 & $\mathrm{R} \$ 2,5$ & $R \$-$ & $R \$-$ & $\mathrm{R} \$ 9,5$ \\
\hline 2010 & $R \$-$ & $R \$-$ & $R S-$ & $R \$-$ & $R S-$ & $R S-$ & RS- & $R \$ 21,0$ & $R \$-$ & RS- & $\mathrm{R} \$ 3,9$ \\
\hline 2011 & $\mathrm{R} \$-$ & $\mathrm{R} \$-$ & $R \$-$ & $R \$-$ & $R \$-$ & $\mathrm{R} \$-$ & 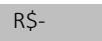 & $\mathrm{R} \$ 12,4$ & $R \$-$ & $R \$-$ & $\mathrm{R} \$ 1,5$ \\
\hline Total & $\mathrm{R} \$ 2.554,4$ & $\mathrm{R} \$ 2.200,3$ & $\mathrm{R} \$ 949,2$ & $\mathrm{R} \$ 758,6$ & $\mathrm{R} \$ 550,4$ & $\mathrm{R} \$ 340,5$ & $\mathrm{R} \$ 331,1$ & $\mathrm{R} \$ 329,6$ & $\mathrm{R} \$ 259,9$ & $\mathrm{R} \$ 213,4$ & $\mathrm{R} \$ 848,8$ \\
\hline$\%$ & $27 \%$ & $24 \%$ & $10 \%$ & $8 \%$ & $6 \%$ & $4 \%$ & $4 \%$ & $4 \%$ & $3 \%$ & $2 \%$ & $9 \%$ \\
\hline
\end{tabular}

Quadro 3.1.6: Financiamento fiscal da Infraestrutura urbana: valores liquidados por ação orçamentária. Valores em milhões. Ano referência de valores: 2016. Fonte: Sistema Integrado de Planejamento e Orçamento, Ministério do Planejamento, Desenvolvimento e Gestão do Governo Federal. Elaboração nossa.

Desconsiderado o eixo Planejamento e Gestão Pública, que tendencialmente é menos custoso por não significar o investimento direto em infraestruturas e financiamento de obras urbanas, é interessante notar que o eixo Infraestrutura Urbana é o menos representativo no âmbito do financiamento fiscal do desenvolvimento urbano, congregando a liquidação de cerca de $\mathrm{R} \$ 9$ bilhões de reais entre 2000 e 2016. Isso pode ser uma evidência a respeito do caráter

${ }^{337}$ A execução orçamentária desse programa aponta para integralização de cotas ao Banco Interamericano de Desenvolvimento (BID); Promoção de investimentos estruturantes no PPA; Captação de recursos externos de organismos financeiros privados multilaterais e governamentais bilaterais; Capacitação de técnicos; Estudo para estabelecimento de estratégias para financiamento do desenvolvimento; Engenharias financeiras para a viabilização de programas estratégicos; Implantação de unidade de parceiras público-privadas no Brasil. Entendendo o BID enquanto agente na produção do espaço urbano no Brasil, esse programa compõe recorte de pesquisa.

${ }^{338}$ 109B - Obras de Infra-estrutura Urbana em Municípios de Médio e Grande Porte, operacionalizada no âmbito do programa 6002 - Apoio ao Desenvolvimento Urbano de Municípios de Médio e Grande Porte. De acordo com o PPA 2004, o objetivo desse programa é apoiar a implantação e/ou adequação de recursos de infraestrutura urbana que contribuam para a qualidade de vida da população por meio de obras ou ações que não se enquadrem nas ações típicas de outros programas.

3395538 - Preservação do Patrimônio Histórico - MONUMENTA; 5538 - Preservação do Patrimônio Histórico Urbano; 5538 - Preservação do Patrimônio Histórico Urbano - Monumenta, ações operacionalizadas no âmbito dos programas 0813 - Monumenta; 0813 - Monumenta - Preservação do Patrimônio Histórico; 0813 MONUMENTA: PRESERVAÇÃO DO PATRIMÔNIO HISTÓRICO. De acordo com o PPA 2008, o objetivo do programa 0813 é revitalizar o patrimônio cultural em centros urbanos, criando condições para a sua sustentabilidade. 
das intervenções territoriais financiadas no âmbito deste eixo, possivelmente pontuais e/ou menos custosas.

A respeito do financiamento fiscal do Planejamento e Gestão Pública (Quadro 3.1.7), destaca-se a ação 20TP, ${ }^{340}$ que corresponde à liquidação de cerca de $R \$ 3$ bilhões, pagamento de pessoal ativo da União, ou seja, pagamento de salários. As ações 2000, ${ }^{341} 2012^{342}$ e 2272,343 operacionalizadas no âmbito de uma série de programas, também correspondem ao pagamento de recursos humanos na administração pública. A ação $2843^{344}$ direciona-se ao funcionamento, manutenção e operação dos sistemas de transporte ferroviário no país. As ações $4426,{ }^{345} 2105^{346}$ e $2114^{347}$ referem-se ao georreferenciamento da malha fundiária nacional, ao gerenciamento do cadastro rural e ao sistema de cadastro rural, respectivamente, ações operacionalizadas no âmbito do programa 0138, referente ao gerenciamento, fiscalização e destinação de estrutura fundiária e de terras públicas no país. A ação $4511^{348}$ corresponde ao pagamento de instituições financeiras pela operacionalização de programas federais. A ação

340 20TP - Pagamento de Pessoal Ativo da União; 20TP - Pessoal Ativo da União, ações operacionalizadas no âmbito do programa 2116 - Programa de Gestão e Manutenção do Ministério das Cidades.

3412000 - Administração da Unidade, ação operacionalizada no âmbito dos programas 0222 - Transporte Ferroviário Urbano de Passageiros, 0778 - Desenvolvimento do Mercado de Valores Mobiliários, 2116 - Programa de Gestão e Manutenção do Ministério das Cidades.

3422012 - Auxílio-Alimentação aos Servidores Civis, Empregados e Militares, 2012 - Auxílio-Alimentação aos Servidores e Empregados, ações operacionalizadas no âmbito dos programas 0272 - Qualidade do Serviço de Energia Elétrica; 0778 - Desenvolvimento do Mercado de Valores Mobiliários; 1295 - Descentralização dos Sistemas de Transporte Ferroviário Urbano de Passageiros; 2116 - Programa de Gestão e Manutenção do Ministério das Cidades.

${ }^{343} 2272$ - Gestão e Administração do Programa, ação adotada por uma série de 25 programas.

3442843 - Funcionamento dos Sistemas de Transporte Ferroviário Urbano de Passageiros; 2843 - Manutenção e Operação dos Sistemas de Transporte Ferroviário de Passageiros, operacionalizadas no âmbito dos programas 0222 - Transporte Ferroviário Urbano de Passageiros; 1295 - Descentralização dos Sistemas de Transporte Ferroviário Urbano de Passageiros; 2116 - Programa de Gestão e Manutenção do Ministério das Cidades.

3454426 - Georreferenciamento da Malha Fundiária Nacional; 4426 - Georreferenciamento de Imóveis Rurais ações operacionalizadas no âmbito dos programas 0138 - Gerenciamento da Estrutura Fundiária e Destinação de Terras Públicas; 0138 - Regularização e Gerenciamento da Estrutura Fundiária.

3462105 - Gerenciamento do Cadastro Rural; 2105 - Gerenciamento e Fiscalização do Cadastro Rural ações operacionalizadas pelos programas 0138 - Gerenciamento da Estrutura Fundiária; 0138 - Gerenciamento da Estrutura Fundiária e Destinação de Terras Públicas; 0138 - Regularização e Gerenciamento da Estrutura Fundiária. 3472114 - Sistema de Cadastro Rural, ação operacionalizada no âmbito dos programas 0138 - Gerenciamento da Estrutura Fundiária; 0138 - Gerenciamento da Estrutura Fundiária e Destinação de Terras Públicas; 0138 Regularização e Gerenciamento da Estrutura Fundiária.

3484511 - Remuneração às Instituições Financeiras Públicas pela Operacionalização de Programas de Saneamento, Habitação e Infra-estrutura Urbana; 4511 - Remuneração às Instituições Financeiras Públicas pela Operacionalização de Projetos de Desenvolvimento Urbano ações operacionalizadas pelo programa 0310 - Gestão da Política de Desenvolvimento Urbano. 
$3955^{349}$ destina-se à capacitação técnica, científica e tecnológica e ao reordenamento institucional e operacional do setor de saneamento, também pelo pagamento de estudos.

Sobre o financiamento fiscal do planejamento e gestão pública, é importante frisar que esses gastos são centrais à execução de políticas, planos e projetos no país, condição à atuação estatal qualificada. ${ }^{350}$ Estudos sobre a administração pública apontam a relevância do gasto com capital humano para as políticas sociais. Core (2001; pp.12-3) destaca a "importância estratégica" do gasto com capital humano, e apresenta ainda a ideia de que o capital intelectual, representado pelo conhecimento existente em determinada instituição, poderia ser agregado aos balanços, por exemplo. Os gastos com capital humano nas áreas de saúde e educação, ou seja, professores, médicos, enfermeiros, por exemplo, são vitais para o acesso público e universal a esses serviços, entendidos enquanto direitos sociais no Brasil. Com as acomodações necessárias, o gasto com capital humano também é uma potência ao desenvolvimento urbano, que se materializa no investimento em planejamento e gestão de políticas públicas, mas que também pode significar o financiamento da prestação de serviços em arquitetura e urbanismo, a exemplo da prática em assessoria técnica, atuação já existente no país.

\footnotetext{
3493955 - Desenvolvimento de Atividades de Capacitação, Assistência Técnica e Desenvolvimento Científico e Tecnológico; 3955 - Estudos para Modernização e Reordenamento Institucional e Operacional do Setor Saneamento; 3955 - Estudos para Modernização e Reordenamento Institucional e Operacional do Setor Saneamento - PMSS II; 3955 - Reordenamento Institucional e Operacional do Setor de Saneamento, ações operacionalizadas pelos programas 0122 - Saneamento É Vida; 0310 - Gestão da Política de Desenvolvimento Urbano; 0311 - Gestão Urbana; 2068 - Saneamento Básico.

${ }^{350}$ Agradecemos aos comentários de doutor Fabio Pereira dos Santos.
} 


\begin{tabular}{|c|c|c|c|c|c|c|c|c|c|c|c|}
\hline \multicolumn{12}{|c|}{ Financiamento fiscal do Planejamento e Gestão Pública: valores liquidados por ação orçamentária } \\
\hline & 20TP & 2843 & 2000 & 2012 & 4426 & 4511 & 2105 & 2272 & 3955 & 2114 & Outras \\
\hline 2000 & $R \$-$ & $\mathrm{R} \$-$ & $\mathrm{R} \$-$ & $R \$-$ & $R \$-$ & $R \$-$ & $\mathrm{R} \$ 12,1$ & $\mathrm{R} \$-$ & $\mathrm{R} \$ 11,4$ & $\mathrm{R} \$ 20,2$ & $\mathrm{R} \$ 73,1$ \\
\hline 2001 & $R \$-$ & $R \$-$ & $R \$-$ & $\mathrm{R} \$-$ & $R \$-$ & $R \$-$ & $\mathrm{R} \$ 11,6$ & $R \$-$ & $R \$ 10,3$ & $\mathrm{R} \$ 18,7$ & $\mathrm{R} \$ 61,2$ \\
\hline 2002 & $R \$-$ & $R \$-$ & $R \$-$ & $R \$-$ & $R \$-$ & $\mathrm{R} \$ 8,3$ & $R \$ 20,9$ & $R \$-$ & $R \$-$ & $R \$ 16,7$ & $R \$ 59,1$ \\
\hline 2003 & $R \$-$ & $R \$-$ & $R \$-$ & $R \$-$ & $R \$-$ & $\mathrm{R} \$ 3,7$ & $\mathrm{R} \$ 19,0$ & $R \$-$ & $R \$-$ & $R \$ 12,6$ & $\mathrm{R} \$ 41,1$ \\
\hline 2004 & $R \$-$ & $R \$-$ & $R \$-$ & $R \$-$ & $R \$ 19,7$ & $R \$ 3,5$ & $R \$ 24,8$ & $\mathrm{R} \$-$ & $R \$ 16,3$ & $\mathrm{R} \$ 11,9$ & $\mathrm{R} \$ 114,8$ \\
\hline 2005 & $R \$-$ & $\mathrm{R} \$-$ & $\mathrm{R} \$-$ & $R \$-$ & $R \$ 25,7$ & $R \$ 3,5$ & $R \$ 51,3$ & $\mathrm{R} \$ 0,8$ & $R \$ 31,6$ & $R \$ 13,4$ & $\mathrm{R} \$ 193,7$ \\
\hline 2006 & $\mathrm{RS}-$ & $\mathrm{R} \$-$ & $\mathrm{R} \$-$ & $R \$-$ & $\mathrm{R} \$ 41,8$ & $\mathrm{R} \$ 19,7$ & $\mathrm{R} \$ 19,2$ & $R \$ 26,2$ & $\mathrm{R} \$ 17,9$ & $\mathrm{R} \$ 10,5$ & $\mathrm{R} \$ 138,2$ \\
\hline 2007 & $R \$-$ & $R \$-$ & $R \$-$ & $R \$-$ & $R \$ 38,2$ & $R \$ 154,2$ & $R \$ 6,2$ & $\mathrm{R} \$ 21,3$ & $R \$ 33,7$ & $R \$ 9,8$ & $\mathrm{R} \$ 80,9$ \\
\hline 2008 & $R \$-$ & $R \$-$ & $R \$-$ & $R \$-$ & $R \$ 23,6$ & $R \$-$ & $\mathrm{R} \$ 9,2$ & $\mathrm{R} \$ 17,8$ & $R \$ 22,1$ & $\mathrm{R} \$ 7,4$ & $\mathrm{R} \$ 130,4$ \\
\hline 2009 & $R \$-$ & $R \$-$ & $R \$-$ & $R \$-$ & $R \$ 10,7$ & $R \$-$ & $R \$ 6,6$ & $R \$ 23,3$ & $R \$-$ & $\mathrm{R} \$ 9,0$ & $\mathrm{R} \$ 102,7$ \\
\hline 2010 & $R \$-$ & $\mathrm{R} \$-$ & $\mathrm{R} \$-$ & $\mathrm{R} \$-$ & $R \$ 29,5$ & $R \$-$ & $\mathrm{R} \$ 6,6$ & $\mathrm{R} \$ 40,1$ & $R \$-$ & $\mathrm{R} \$ 4,1$ & $\mathrm{R} \$ 71,6$ \\
\hline 2011 & $\mathrm{R} \$-$ & $R \$-$ & $R \$-$ & $\mathrm{R} \$-$ & $R \$ 22,0$ & $R \$-$ & $\mathrm{R} \$ 2,0$ & $\mathrm{R} \$ 32,7$ & $\mathrm{R} \$-$ & $\mathrm{R} \$ 7,0$ & $\mathrm{R} \$ 38,5$ \\
\hline 2012 & $\mathrm{R} \$ 546,9$ & $\mathrm{R} \$ 275,4$ & $\mathrm{R} \$ 84,1$ & $\mathrm{R} \$ 36,7$ & $R \$-$ & $\mathrm{R} \$-$ & $\mathrm{R} \$-$ & $\mathrm{R} \$-$ & $\mathrm{R} \$-$ & $\mathrm{R} \$-$ & $\mathrm{R} \$ 57,2$ \\
\hline 2013 & $\mathrm{R} \$ 610,0$ & $R \$ 264,5$ & $\mathrm{R} \$ 74,4$ & $\mathrm{R} \$ 40,3$ & $\mathrm{R} \$-$ & $\mathrm{R} \$-$ & $R \$-$ & $R \$-$ & $R \$-$ & $\mathrm{R} \$-$ & $\mathrm{R} \$ 72,1$ \\
\hline 2014 & $\mathrm{R} \$ 609,9$ & $\mathrm{R} \$ 271,1$ & $\mathrm{R} \$ 80,7$ & $\mathrm{R} \$ 46,0$ & $R \$-$ & $R \$-$ & $R \$-$ & $\mathrm{R} \$-$ & $\mathrm{R} \$-$ & $\mathrm{R} \$-$ & $\mathrm{R} \$ 41,1$ \\
\hline 2015 & $R \$ 640,4$ & $R \$ 275,8$ & $R \$ 78,7$ & $R \$ 55,4$ & $R \$-$ & $R \$-$ & $\mathrm{R} \$-$ & $\mathrm{R} \$-$ & $R \$-$ & $\mathrm{R} \$-$ & $R \$ 56,0$ \\
\hline 2016 & $\mathrm{R} \$ 651,3$ & $\mathrm{R} \$ 267,9$ & $\mathrm{R} \$ 77,3$ & $\mathrm{R} \$ 56,2$ & $\mathrm{R} \$-$ & $\mathrm{R} \$-$ & $\mathrm{R} \$-$ & $\mathrm{R} \$-$ & $\mathrm{R} \$-$ & $\mathrm{R} \$-$ & $\mathrm{R} \$ 56,6$ \\
\hline Total & $\mathrm{R} \$ 3.058,5$ & $\mathrm{R} \$ 1.354,8$ & $\mathrm{R} \$ 395,2$ & $\mathrm{R} \$ 234,5$ & $\mathrm{R} \$ 211,3$ & $\mathrm{R} \$ 192,9$ & $\mathrm{R} \$ 189,4$ & $\mathrm{R} \$ 162,2$ & $\mathrm{R} \$ 143,3$ & $\mathrm{R} \$ 141,3$ & $\mathrm{R} \$ 1.388,6$ \\
\hline$\%$ & $41 \%$ & $18 \%$ & $5 \%$ & $3 \%$ & $3 \%$ & $3 \%$ & $3 \%$ & $2 \%$ & $2 \%$ & $2 \%$ & $19 \%$ \\
\hline
\end{tabular}

Quadro 3.1.7: Financiamento fiscal do Planejamento e Gestão Pública: valores liquidados por ação orçamentária. Valores em milhões. Ano referência de valores: 2016. Fonte: Sistema Integrado de Planejamento e Orçamento, Ministério do Planejamento, Desenvolvimento e Gestão do Governo Federal. Elaboração nossa.

Por fim, o estudo do financiamento fiscal do desenvolvimento urbano a partir do eixo das Operações Especiais. As operações especiais não são programas implementados a partir das políticas urbanas e habitacionais. De modo geral, as operações especiais referem-se a operações de financiamento e encargos delas decorrentes, a exemplo de empréstimos, financiamentos diretos, concessões de créditos, equalizações, subvenções, subsídios, coberturas de garantias, coberturas de resultados, honras de aval, assistência financeira, reembolsáveis ou não. Ainda, podem referir-se a complementações ou compensações financeiras. Segundo o Manual técnico de orçamento (MTO) versão 2012 (Brasil, 2011; pp.3940), as operações especiais são: 
Despesas que não contribuem para a manutenção, expansão ou aperfeiçoamento das ações de governo, das quais não resulta um produto e não geram contraprestação direta sob a forma de bens ou serviços. Exemplos: amortização, juros, encargos e rolagem da dívida contratual e mobiliária; pagamento de aposentadorias e pensões; transferências constitucionais ou legais por repartição de receita (FPM, FPE, Salário- Educação, Compensação de Tributos ou Participações aos Estados, Distrito Federal e Municípios, Transferências ao Governo do Distrito Federal); pagamento de indenizações, ressarcimentos, abonos, seguros, auxílios, benefícios previdenciários, benefícios de assistência social; reserva de contingência, inclusive as decorrentes de receitas próprias ou vinculadas; cumprimento de sentenças judiciais (precatórios, sentenças de pequeno valor, sentenças contra empresas, débitos vincendos etc); operações de financiamento e encargos delas decorrentes (empréstimos, financiamentos diretos, concessão de créditos, equalizações, subvenções, subsídios, coberturas de garantias, coberturas de resultados, honras de aval, assistência financeira), reembolsáveis ou não; ações de reservas técnicas (centralização de recursos para atender concursos, provimentos, nomeações, reestruturação de carreiras etc); complementação ou compensação financeira da União; contraprestação da União nos contratos de Parcerias Público-Privadas; contribuição a organismos e/ou entidades nacionais ou internacionais; integralização e/ou recomposição de cotas de capital junto a entidades internacionais; contribuição à previdência privada; contribuição patronal da União ao Regime de Previdência dos Servidores Públicos; desapropriação de ações, dissolução ou liquidação de empresas; encargos financeiros (decorrentes da aquisição de ativos, questões previdenciárias ou outras situações em que a União assuma garantia de operação); operações relativas à subscrição de ações; indenizações financeiras (anistiados políticos, programas de garantias de preços etc); participação da União no capital de empresas nacionais ou internacionais; e outras.

Apesar disso, e a partir da execução do Orçamento Geral da União, as operações especiais não poderiam ser descartadas por nosso estudo, dado que contribuem ao entendimento do financiamento de implantação do metrô de Distrito Federal, à estabilidade financeira de Sistema Financeiro da Habitação, à implementação e melhoria de infraestrutura de transportes rodoviário e portuário, e à operacionalização de projetos de desenvolvimento urbano promovidos pelo Ministério das Cidades, por exemplo. ${ }^{351}$

\footnotetext{
351 Por operações especiais nos referimos aos programas "0904 - Operações Especiais: Outras Transferências", "0909 - Operações Especiais: Outros Encargos Especiais" e "0911 - Operações Especiais - Remuneração de Agentes Financeiros".
} 
A respeito das operações especiais e com atenção ao desenvolvimento urbano (Quadro 3.1.8), destacam-se as ações $000 B^{352}$ e 0737, ${ }^{353}$ ambas pertinentes ao setor de energia elétrica. Essas ações são relativas à expansão da oferta de energia elétrica emergencial; cobertura do bônus individual a consumidores residenciais de energia elétrica; e às concessões de geração, transmissão e distribuição de energia elétrica, encargos setoriais e modicidade tarifária. As ações $0023,{ }^{354} 0467,,^{355} 0465^{356}$ e $0617^{357}$ são pertinentes ao setor habitacional. Essas ações se referem à saúde fiscal do Sistema Financeiro da Habitação (SFH), e até mesmo do FUNDHAB, Fundo de Assistência Habitacional criado em 1964 com vistas a financiar operações de interesse social no âmbito do SFH e cobertura de saldos devedores dos contratos de financiamento dos mutuários, por exemplo. Além disso, destaca-se a remuneração de agentes financeiros para a administração do FCVS. O Fundo de Compensação de Variações Salariais (FCVS) é um fundo criado em 1967, ratificado em 1997, "com a finalidade precípua de garantir o limite de prazo para amortização da dívida dos mutuários decorrentes de financiamentos habitacionais", segundo a CEF. A regulação do FCVS ainda sofre ajustes em 2011. ${ }^{358}$

352 00OB - Auxílio à Conta de Desenvolvimento Energético (Leis nos 10.438, de 26/04/2002, e 12.783, de 11/01/2013), ação operacionalizada no âmbito do programa 0909 - Operações Especiais: Outros Encargos Especiais.

3530737 - Complementação de Recursos para Pagamento de Bônus a Consumidores Residenciais de Energia Elétrica, MP N. 4, de 17/10/2001, ação operacionalizada no âmbito do programa 0909 - Operações Especiais: Outros Encargos Especiais.

${ }^{354} 0023$ - Cobertura do Resíduo Resultante de Contratos Firmados com o Sistema Financeiro da Habitação, ação operacionalizada no âmbito do programa 0909 - Operações Especiais: Outros Encargos Especiais.

3550467 - Cobertura de Sinistros do Seguro de Crédito FUNDHAB, ação operacionalizada no âmbito do programa 0909 - Operações Especiais: Outros Encargos Especiais.

3560465 - Cobertura do Déficit do Seguro Habitacional, ação operacionalizada no âmbito do programa 0909 Operações Especiais: Outros Encargos Especiais.

3570617 - Remuneração aos Agentes Gestores Pela Administração do Fcvs; 0617 - Remuneração de Agentes Financeiros pela Administração do FCVS; 0617 - Remuneração de Agentes Financeiros pela Administração do FCVS e do Seguro de Crédito; 0617 - Remuneração de Agentes Financeiros pela Administração do FCVS, do Seguro de Crédito e do Seguro Habitacional, ações operacionalizadas no âmbito do programa 0909 - Operações Especiais: Outros Encargos Especiais.

358 “A partir da edição da Lei no 12.409, de 25/05/2011, compete ao FCVS a assunção dos direitos e obrigações do extinto Seguro Habitacional do SFH - SH/SFH e o oferecimento de cobertura direta a contratos de financiamento habitacional averbados na Apólice Pública do SH/SFH e dessa forma, o FCVS, também denominado FCVS Garantia, liquidará ou amortizará o saldo do financiamento habitacional, em caso de Morte ou Invalidez Permanente - MIP do adquirente e assumirá as despesas de recuperação ou indenização decorrentes de danos físicos no imóvel DFI." Fonte: <https://fundosdegoverno.caixa.gov.br/sicfg/fundos/FCVS/detalhe/sobre/>, consultado em novembro de 2019. 
A ação 0C34 ${ }^{359}$ significa fonte de recursos adicionais para a ampliação de limites operacionais da CEF, sendo esses recursos aplicados em saneamento básico, habitação popular e outras operações previstas no estatuto social da CEF, segundo MP №347 de 2007. A ação $00 C R^{360}$ refere-se à participação da União em Fundo de Garantia a Empreendimentos de Energia Elétrica (FGEE), "que terá por finalidade prestar garantias proporcionais à participação, direta ou indireta, de empresa estatal federal do setor elétrico em sociedade de propósito específico, constituída para a construção de empreendimentos de energia elétrica constantes do Programa de Aceleração do Crescimento - PAC, nos financiamentos concedidos por instituição financeira federal e por seus agentes repassadores", tal como atesta MP № 450 de 2008. As ações 00AF 361 e $00 \mathrm{CW}^{362}$ referem-se ao financiamento de $\mathrm{PMCMV}$, por meio da transferência de recursos fiscais ao Fundo de Arrendamento Residencial (FAR) e Fundo de Desenvolvimento Social (FDS), por exemplo, tema já debatido anteriormente.

359 0C34 - Concessão de Crédito à Caixa Econômica Federal na Forma de Instrumento Híbrido de Capital e Dívida (Medida Provisória no 347, de 2007), ação operacionalizada no âmbito do programa 0909 - Operações Especiais: Outros Encargos Especiais.

360 O0CR - Concessão de Crédito ao Banco Nacional de Desenvolvimento Econômico e Social - BNDES (MP no 450, de 2008), ação operacionalizada no âmbito do programa 0909 - Operações Especiais: Outros Encargos Especiais.

${ }^{361}$ OOAF - Integralização de Cotas ao Fundo de Arrendamento Residencial - FAR; 00AF - Transferência ao Fundo de Arrendamento Residencial - FAR, ações operacionalizadas no âmbito do programa 0909 - Operações Especiais: Outros Encargos Especiais; 2049 - Moradia Digna; 9991 - Habitação de Interesse Social.

362 00CW - Subvenção Econômica Destinada a Implementação de Projetos de Interesse Social em Áreas Urbanas (Lei no 11.977, de 2009); 00CW - Subvenção Econômica destinada à implementação de Projetos de Interesse Social em Áreas Urbanas (MP 459, de 2009), ações operacionalizadas no âmbito dos programas 0909 - Operações Especiais: Outros Encargos Especiais e 2049 - Moradia Digna.

Em acordo com a Lei no 11.977, de 2009 e MP № 459, de 2009, a União ainda poderia participar do Fundo Garantidor da Habitação Popular - FGHab e conceder subvenção econômica ao Banco Nacional de Desenvolvimento Econômico e Social - BNDES. 


\begin{tabular}{|c|c|c|c|c|c|c|c|c|c|c|c|}
\hline \multicolumn{12}{|c|}{ Financiamento fiscal das Operações Especiais: valores liquidados por ação orçamentária } \\
\hline & OOOB & 0023 & $0 \mathrm{C34}$ & OOCR & OOAF & 0617 & 0737 & 0467 & 0465 & OOCW & Outras \\
\hline 2000 & $\mathrm{R} \$-$ & $\mathrm{R} \$ 3.757,2$ & R\$- & $\mathrm{R} \$-$ & $R \$-$ & $\mathrm{R} \$ 146,7$ & $R \$-$ & R\$- & R\$- & $R \$-$ & $\mathrm{R} \$ 104,1$ \\
\hline 2001 & $\mathrm{R} \$-$ & $\mathrm{R} \$ 339,8$ & RŞ- & RS\$- & RŞ- & $R \$-$ & $\mathrm{R} \$ 132,3$ & RȘ- & RŞ- & RS- & $\mathrm{R} \$ 111,4$ \\
\hline 2002 & RS- & $\mathrm{R} \$ 2.239,6$ & $R \$-$ & R\$- & RŞ- & $\mathrm{R} \$ 291,3$ & $\mathrm{R} \$ 1.508,9$ & $\mathrm{R} \$ 226,6$ & $\mathrm{R} \$ 56,4$ & RS- & R\$- \\
\hline 2003 & R\$- & $\mathrm{R} \$ 1.142,3$ & $R \$-$ & $R \$-$ & R\$- & $\mathrm{R} \$ 298,6$ & $R \$-$ & $\mathrm{R} \$ 231,9$ & $\mathrm{R} \$ 79,1$ & R\$- & $\mathrm{R} \$-$ \\
\hline 2004 & $\mathrm{R} \$-$ & $\mathrm{R} \$ 971,6$ & $R \$-$ & R\$- & RŞ- & $\mathrm{R} \$ 290,0$ & RS- & $\mathrm{R} \$ 80,3$ & R\$̦- & RS- & $R \$-$ \\
\hline 2005 & $R \$-$ & $R \$ 602,4$ & $R \$-$ & $R \$-$ & R\$- & $\mathrm{R} \$ 274,8$ & $R \$-$ & $\mathrm{R} \$ 86,3$ & RS- & R\$- & $\mathrm{R} \$ 105,6$ \\
\hline 2006 & RS\$- & $\mathrm{R} \$ 458,8$ & $\mathrm{R} \$-$ & R\$- & R\$- & $\mathrm{R} \$ 260,0$ & R\$- & $\mathrm{R} \$ 55,1$ & $\mathrm{R} \$ 293,7$ & RS- & $\mathrm{R} \$-$ \\
\hline 2007 & $R \$-$ & $\mathrm{R} \$ 19,5$ & $R \$ 9.158,5$ & R\$- & R\$- & $\mathrm{R} \$ 130,8$ & $R \$-$ & $R \$-$ & $\mathrm{R} \$ 19,3$ & RS- & $R \$-$ \\
\hline 2008 & RS\$- & $\mathrm{R} \$ 101,0$ & $\mathrm{R} \$-$ & R\$- & $R \$-$ & $\mathrm{R} \$ 154,2$ & $R \$-$ & R\$- & $R \$ 21,5$ & $\mathrm{R} \$-$ & $R \$-$ \\
\hline 2009 & $R \$-$ & $\mathrm{R} \$ 29,7$ & $R \$-$ & $R \$-$ & $R \$ 2.213,9$ & $\mathrm{R} \$ 127,4$ & $R \$-$ & $R \$-$ & $\mathrm{R} \$ 219,1$ & $\mathrm{R} \$ 714,8$ & $R \$ 436,8$ \\
\hline 2010 & R\$- & $\mathrm{R} \$ 44,7$ & $R \$-$ & $\mathrm{R} \$ 3.445,0$ & $\mathrm{R} \$-$ & $\mathrm{R} \$ 110,8$ & R\$- & $R \$-$ & $R \$-$ & $R \$-$ & $R \$ 215,5$ \\
\hline 2011 & $R \$-$ & $R \$ 64,5$ & $R \$-$ & $\mathrm{R} \$-$ & $\mathrm{R} \$ 823,5$ & $R \$ 52,9$ & $R \$-$ & RS- & $R \$-$ & $R \$-$ & $\mathrm{R} \$ 21,1$ \\
\hline 2012 & R\$- & $\mathrm{R} \$ 157,6$ & $R \$-$ & $R \$-$ & $\mathrm{R} \$-$ & $\mathrm{R} \$ 125,0$ & R\$- & $R \$-$ & $\mathrm{R} \$ 333,4$ & RS- & $R \$-$ \\
\hline 2013 & R\$- & $\mathrm{R} \$ 802,2$ & $R \$-$ & $R \$-$ & RS- & $\mathrm{R} \$ 138,2$ & $R \$-$ & RȘ- & $R \$-$ & R\$- & R\$- \\
\hline 2014 & $R \$ 12.397,7$ & $\mathrm{R} \$ 82,8$ & $R \$-$ & $R \$-$ & R\$- & $\mathrm{R} \$ 152,5$ & $R \$-$ & $\mathrm{R} \$-$ & $R \$-$ & RS- & RS- \\
\hline 2015 & $\mathrm{R} \$ 107,3$ & $R \$ 47,9$ & $R \$-$ & $R \$-$ & RS- & $\mathrm{R} \$ 132,6$ & $R \$-$ & $R \$ 500,4$ & $R \$-$ & $R \$-$ & $R \$-$ \\
\hline 2016 & $R \$-$ & $\mathrm{R} \$-$ & $\mathrm{R} \$-$ & $R \$-$ & $R \$-$ & $R \$-$ & $R \$-$ & $\mathrm{R} \$-$ & $R \$-$ & $R \$-$ & $R \$-$ \\
\hline Total & $\mathrm{R} \$ 12.505,0$ & $\mathrm{R} \$ 10.861,5$ & $\mathrm{R} \$ 9.158,5$ & $\mathrm{R} \$ 3.445,0$ & $\mathrm{R} \$ 3.037,4$ & $\mathrm{R} \$ 2.685,7$ & $\mathrm{R} \$ 1.641,3$ & $\mathrm{R} \$ 1.180,6$ & $\mathrm{R} \$ 1.022,5$ & $\mathrm{R} \$ 714,8$ & $\mathrm{R} \$ 994,5$ \\
\hline$\%$ & $26 \%$ & $23 \%$ & $19 \%$ & $7 \%$ & $6 \%$ & $6 \%$ & $3 \%$ & $2 \%$ & $2 \%$ & $2 \%$ & $2 \%$ \\
\hline
\end{tabular}

Quadro 3.1.8: Financiamento fiscal das Operações Especiais: valores liquidados por ação orçamentária. Valores em milhões. Ano referência de valores: 2016. Fonte: Sistema Integrado de Planejamento e Orçamento, Ministério do Planejamento, Desenvolvimento e Gestão do Governo Federal. Elaboração nossa.

Em suma, por um lado, a presente seção demonstra que $\mathrm{R} \$ 204$ bilhões de reais oriundos do Orçamento Geral da União foram liquidados em prol do desenvolvimento urbano entre 2000 e 2016. Com isso, a esfera federal financiou a urbanização de favelas e assentamentos precários, construção de casas, ampliação e qualificação do acesso aos serviços urbanos de água, esgoto, drenagem urbana, energia elétrica, mobilidade urbana, de gestão dos resíduos sólidos, qualificação da gestão de terras públicas e do patrimônio histórico, e gestão e planejamento estatais, por exemplo. O Programa de Aceleração do Crescimento (PAC) - Urbanização de Assentamentos Precários e os subsídios à Faixa 1 de Programa Minha Casa, Minha Vida são exemplos da atuação federal e produtos do financiamento federal e fiscal durante os últimos governos. Com isso, a esfera federal contribuiu ativamente ao desenvolvimento urbano nacional, em grande parte orientada pelo corpo burocrático do Ministério das Cidades.

Por outro lado, a avaliação do financiamento fiscal aponta diferenças entre os diferentes os eixos do desenvolvimento urbano, seja em temos de montantes liquidados, seja em termos de estratégias dessa liquidação. Os setores sociais mobilizados pelos diferentes eixos do desenvolvimento urbano são distintos, uma vez que a presente seção se refere tanto às 
concessionárias do setor da energia elétrica, como ao subsetor produtivo edificações ou ao subsetor produtivo infraestrutura. Os desafios à universalização das diferentes infraestruturas e serviços devem ser particularizados.

Para além das particularidades entre os eixos do desenvolvimento urbano, os dados ilustram diversidades no modo da atuação estatal frente ao urbano entre 2000 e 2016. Uma importante liquidação de recursos esteve associada à centralidade da agência privada, seja por meio de uma atuação garantidora do mercado de energia elétrica e da atuação das concessionárias de serviços urbanos, seja por meio do acesso subsidiado a unidades habitacionais produzidas via mercado, subsetor produtivo edificações. Mesmo a garantia ou a ampliação de mercados demanda expressiva alocação de recursos fiscais. A ideia das companhias estaduais de habitação, ícones da promoção pública da infraestrutura urbana e habitacional, por exemplo, parece tratar-se de uma experiência própria do século XX, de um outro momento histórico e concepção de Estado e, neste sentido, há evidências de uma mudança longa, processual, longe de disruptiva. ${ }^{363}$ A execução descentralizada dos recursos federais, já tratada anteriormente, que confere aos governos subnacionais possibilidades de determinação dos processos em torno do desenvolvimento urbano, quando viabilizada, é expressão desse processo econômico, social e político não linear.

\footnotetext{
${ }^{363}$ Cf. capítulo 1.
} 


\subsection{Expressão territorial do financiamento fiscal do desenvolvimento urbano}

Não são recentes os esforços em atribuir feições territoriais ao gasto público no Brasil, por um lado, contribuindo para o planejamento de atuação estatal, por outro lado, para a sua avaliação. O ciclo orçamentário, para citar tópico de atuação estatal, é completo quando dotado de elaboração, aprovação, execução, avaliação. Ainda, o campo da administração pública apresenta a função alocativa, a função distributiva e a função estabilizadora enquanto funções do orçamento público, e essas funções podem ser debatidas à luz da variável territorial. Vale lembrar, o Brasil é país dotado de expressivas desigualdades, de modo que o orçamento público pode ser relacionado às desigualdades territoriais, e disso decorre, por exemplo, a categorização do gasto público por regiões apresentada por alguns planos plurianuais federais.

Aos urbanistas, contudo, reconhecendo a relevância de atuação estatal à produção do urbano, o estudo sobre o gasto público é mobilizado no sentido de melhor compreender o processo e resultado de atuação estatal sobre as cidades no país, por vezes também interessados na qualificação dessa atuação e assumindo o pressuposto que a alocação territorial do gasto público é dimensão relevante à compreensão e realização desse gasto. Neste sentido, enquanto dimensão de abordagem exploratória construída pelo presente trabalho, é apresentado georreferenciamento do financiamento fiscal do desenvolvimento urbano a partir de execução do Orçamento Geral da União para o período de 2000 a 2016.

A partir de banco de dados da execução orçamentária federal é possível construir uma avaliação territorial sobre o gasto público, contudo ainda de modo dificultoso. O banco de dados objeto de estudo é dotado da categoria "localizador", que melhor permite uma compreensão individualizada da rubrica orçamentária, e menos uma compreensão abrangente. A não uniformização de procedimentos durante a construção desse banco de dados representa um desafio ao processamento das informações, as quais não estão padronizadas. 0 georreferenciamento aqui apresentado apenas foi possível a partir do estudo detalhado das dotações orçamentárias, a partir da categoria "localizador", qualificando a execução do 
orçamento por jurisdições (municípios e estados) a partir da codificação IBGE. ${ }^{364}$ Com isso, é possível a produção de cartografias, mas também de processamentos secundários, e o estudo de correlações espaciais entre gasto público, riqueza de jurisdições e precariedades urbana e habitacional, por exemplo. Ao adotar a codificação IBGE as possibilidades de desenvolvimento de estudos e associação entre diferentes bancos de dados são ampliadas de modo significativo. Superado o esforço no tratamento dos dados primários, a presente seção avança sobre a compreensão das relações entre financiamento fiscal do desenvolvimento urbano, eixos do desenvolvimento urbano e expressão territorial desse gasto público, ou seja, a alocação territorial dos recursos oriundos do Orçamento Geral da União entre 2000 e $2016 .{ }^{365}$

Cabe frisar, mesmo a partir do estudo detalhado das rubricas orçamentárias, ainda não é possível uma territorialização total dos recursos federais destinados ao financiamento fiscal das infraestruturas urbanas e habitacionais no país (Quadro 3.2.1). Ora as dificuldades remontam à qualidade de banco de dados, esta já debatida, ora ao modo como são operacionalizados esses recursos federais. Como já demonstrado, parcela significativa dos recursos não-onerosos são executados por agências financeiras, a exemplo da Caixa Econômica Federal e Banco Nacional de Desenvolvimento Econômico e Social, o que demanda a sistematização e processamento de novos bancos de dados, ou até mesmo o estudo detalhado de contratos. Consciente dos limites associados às informações aqui construídas, o presente estudo evidencia o montante financeiro liquidado passível de territorialização, o que significa a

364 O Quadro Anexo 4 apresenta territorialização do financiamento fiscal do desenvolvimento urbano: Valores empenhados por Estado (Milhões). O Quadro Anexo 5 apresenta territorialização do financiamento fiscal do desenvolvimento urbano: Valores liquidados por Estado (Milhões)

${ }^{365}$ A alocação territorial do gasto público não representa, exatamente, o agente executor desses recursos. Pode ser possível, hipoteticamente, o mapeamento de obra urbana no município de Paraty, executado pelo governo do estado do Rio de Janeiro, financiado com recursos fiscais federais, sendo o financiamento condicionado a uma contrapartida estadual e/ou municipal, por exemplo. Neste sentido, denotamos a complexidade de um estudo holístico sobre os produtos de atuação estatal sobre o espaço urbano: seria necessário avaliar, de modo concomitante, a atuação das esferas federal, estadual e local, o que significa o estudo de 5.598 orçamentos públicos. Ainda caberia identificar a atuação das agências financeiras, com atenção aos fundos parafiscais, a exemplo do FGTS, por exemplo. A validade do presente estudo está na concentração dos recursos públicos por esfera federal.

Apesar da alocação territorial do gasto público não representar a execução desses recursos, tendencialmente a expressão territorial do financiamento fiscal do desenvolvimento urbano encontra relação nas competências e capacidades administrativas e financeiras de estados e municípios, fenômeno melhor tratado pela seção 3.3 do presente trabalho. 
territorialização por estados de $22 \%$ dos recursos liquidados; territorialização por municípios de 4\% dos recursos liquidados. ${ }^{366}$ Apesar das limitações, ainda é possível observar a expressão territorial de financiamento fiscal do desenvolvimento urbano brasileiro. A presente seção concentra-se, assim, sobre os recursos liquidados organizados por municípios.

\begin{tabular}{|c|c|c|c|c|}
\hline & Valor empenhado & \% (Empenho) & Valor liquidado & \% (Liquidação) \\
\hline $\begin{array}{l}\text { Financiamento fiscal do } \\
\text { desenvolvimento urbano }\end{array}$ & $R \$ 352.921 .324 .087$ & $100 \%$ & $R \$ 204.383 .935 .241$ & $100 \%$ \\
\hline $\begin{array}{l}\text { Territorialização possível por } \\
\text { Estados e DF ou Região }\end{array}$ & $R \$ 88.943 .302 .135$ & $25 \%$ & $\mathrm{R} \$ 45.974 .810 .080$ & $22 \%$ \\
\hline $\begin{array}{l}\text { Territorialização possível por } \\
\text { Municípios }\end{array}$ & $\mathrm{R} \$ 16.069 .812 .141$ & $5 \%$ & $R \$ 9.147 .322 .021$ & $4 \%$ \\
\hline
\end{tabular}

Quadro 3.2.1: Territorialização do financiamento fiscal do desenvolvimento urbano a partir da execução do Orçamento Geral da União, 2000 a 2016. Ano referência de valores: 2016. Fonte: Sistema Integrado de Planejamento e Orçamento, Ministério do Planejamento, Desenvolvimento e Gestão do Governo Federal. Elaboração nossa.

Com atenção aos mais de R\$9 bilhões liquidados e territorializados por municípios, é possível observar que a grande parte dos municípios brasileiros é afetada pela atuação estatal federal, atuação financiada por recursos oriundos do Orçamento Geral da União. Ao menos ${ }^{367}$ 3.267 municípios brasileiros são beneficiados pela liquidação de recursos federais, o que pode significar a viabilização de infraestrutura urbana e habitacional ou até mesmo de projetos (Imagem 3.2.1). Isso denota a alta capilaridade territorial apresentada pelo gasto público federal, execução orçamentária federal, pelo financiamento fiscal do desenvolvimento urbano no Brasil. É possível observar que, especialmente a partir de 2012, a territorialização do financiamento fiscal do desenvolvimento urbano é mínima, por motivos já debatidos, relativos à operacionalização do gasto público.

\footnotetext{
${ }^{366}$ A Fundação Tide Setubal desenvolveu pesquisas sobre a regionalização do orçamento público em grandes cidades e a dimensão territorial do orçamento público. Essas pesquisas foram conduzidas por Pedro de Lima Marin e Tomás Wissenbach, respectivamente. Essas pesquisas dedicam especial atenção às municipalidades, mas ainda contribuem ao debate apresentado por nós. A territorialização do gasto público é dificultosa, seja pela organização dos dados orçamentários, seja pela finalidade do gasto público. Esses estudos tratam, inclusive, da categoria "não regionalizável". Resguardadas as diferenças quanti-qualitativas entre orçamentos municipais e federal, os desafios à territorialização do gasto público são transversais. As pesquisas mencionadas encontram-se disponíveis em: $<$ https://fundacaotidesetubal.org.br/downloads/publicacoes/2988/regionalizacao-de-orcamento-em-grandescidades-o-estado-da-arte>; <https://fundacaotidesetubal.org.br/downloads/getFile/2983/8186/e2984fdba5ae5ff842828586e45ad48d> , links consultados em fevereiro de 2020.

367 Dado que $96 \%$ do gasto não foi territorializado por municípios, é provável que o número de municípios beneficiados seja ainda mais amplo.
} 


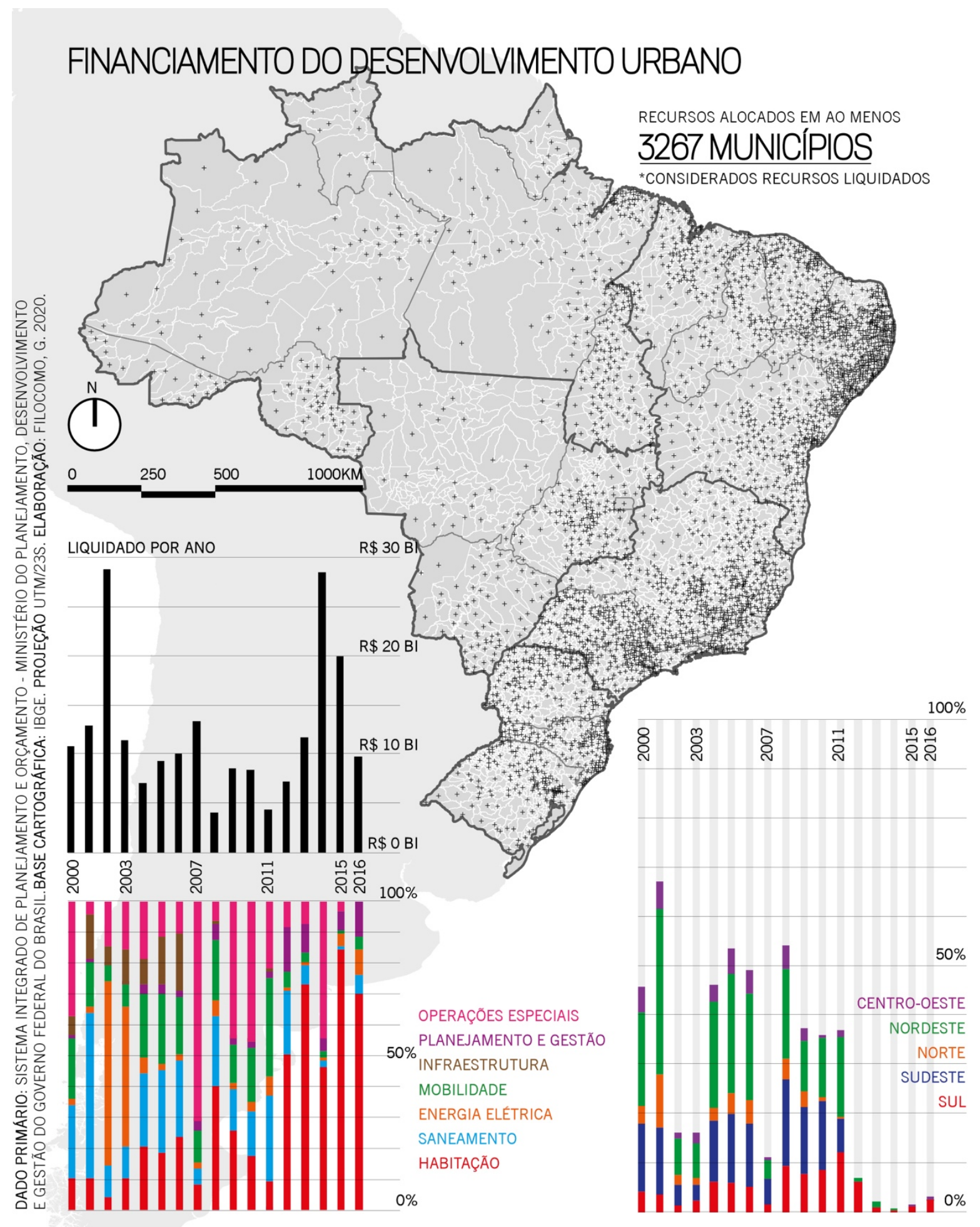

Imagem 3.2.1: Financiamento fiscal do desenvolvimento urbano entre 2000 e 2016: alocação territorial dos gastos com desenvolvimento urbano, alocação organizada por município. Elaboração nossa. 
Como um todo, mas em especial para o período de 2000 a 2011, é possível observar maior liquidação de recursos em prol das regiões Nordeste (9\%) e Sudeste (6\%). A região Sul concentra 3\% dos recursos liquidados, e as regiões Centro-Oeste e Norte 2\% cada uma (Quadro 3.2.2). A concentração do financiamento fiscal do desenvolvimento urbano na região Nordeste e Sudeste corresponde à concentração de pobreza e à concentração da população urbana no país, uma correspondência com aparentes desdobramentos positivos, mas uma maior assertividade sobre os impactos de atuação estatal demandaria novos estudos.

\begin{tabular}{|c|c|c|c|c|c|c|}
\hline \multicolumn{7}{|c|}{ Territorialização do financiamento fiscal do desenvolvimento urbano por região } \\
\hline Ano & $\begin{array}{l}\text { Centro- } \\
\text { Oeste }\end{array}$ & Nordeste & Norte & Sudeste & Sul & Não especificado \\
\hline 2000 & $\mathrm{R} \$ 537$ & $R \$ 2.030$ & $R \$ 384$ & $\mathrm{R} \$ 1.489$ & $\mathrm{R} \$ 441$ & $R \$ 5.808$ \\
\hline 2001 & $\mathrm{R} \$ 720$ & $\mathrm{R} \$ 4.284$ & $\mathrm{R} \$ 1.378$ & $\mathrm{R} \$ 1.716$ & $\mathrm{R} \$ 460$ & $\mathrm{R} \$ 4.175$ \\
\hline 2002 & $R \$ 354$ & $\mathrm{R} \$ 2.115$ & $\mathrm{R} \$ 560$ & $\mathrm{R} \$ 1.214$ & $R \$ 384$ & $R \$ 24.009$ \\
\hline 2003 & $R \$ 232$ & $\mathrm{R} \$ 789$ & $R \$ 171$ & $R \$ 360$ & $R \$ 261$ & $R \$ 9.429$ \\
\hline 2004 & $R \$ 250$ & $\mathrm{R} \$ 1.511$ & $R \$ 190$ & $\mathrm{R} \$ 867$ & $R \$ 433$ & $R \$ 3.782$ \\
\hline 2005 & $R \$ 482$ & $\mathrm{R} \$ 2.244$ & $R \$ 384$ & $\mathrm{R} \$ 1.295$ & $R \$ 555$ & $\mathrm{R} \$ 4.314$ \\
\hline 2006 & $\mathrm{R} \$ 484$ & $R \$ 2.165$ & $\mathrm{R} \$ 471$ & $R \$ 1.296$ & $\mathrm{R} \$ 512$ & $R \$ 5.080$ \\
\hline 2007 & $R \$ 58$ & $R \$ 506$ & $\mathrm{R} \$ 12$ & $R \$ 683$ & $R \$ 210$ & $\mathrm{R} \$ 11.739$ \\
\hline 2008 & $R \$ 184$ & $R \$ 719$ & $R \$ 162$ & $\mathrm{R} \$ 694$ & $R \$ 368$ & $\mathrm{R} \$ 1.807$ \\
\hline 2009 & $R \$ 227$ & $\mathrm{R} \$ 857$ & $R \$ 265$ & $\mathrm{R} \$ 1.147$ & $R \$ 667$ & $R \$ 5.294$ \\
\hline 2010 & $R \$ 61$ & $\mathrm{R} \$ 1.001$ & $\mathrm{R} \$ 57$ & $\mathrm{R} \$ 1.171$ & $R \$ 723$ & $\mathrm{R} \$ 5.348$ \\
\hline 2011 & $\mathrm{R} \$ 60$ & $\mathrm{R} \$ 701$ & $\mathrm{R} \$ 15$ & $\mathrm{R} \$ 287$ & $\mathrm{R} \$ 524$ & $R \$ 2.700$ \\
\hline 2012 & $\mathrm{RS}-$ & $\mathrm{R} \$ 44$ & $\mathrm{R} \$-$ & $\mathrm{R} \$ 0^{\circ}$ & $R \$ 450$ & $R \$ 6.669$ \\
\hline 2013 & $R \$-$ & $R \$ 148$ & $R \$-$ & $\mathrm{R} \$-$ & $R \$ 105$ & $\mathrm{R} \$ 11.364$ \\
\hline 2014 & $\mathrm{R} \$-$ & $R \$ 131$ & $R \$-$ & $R \$-$ & $R \$ 111$ & $\mathrm{R} \$ 28.081$ \\
\hline 2015 & $\mathrm{R} \$ 54$ & $R \$-$ & $R \$-$ & $R \$-$ & $R \$ 245$ & $\mathrm{R} \$ 19.440$ \\
\hline 2016 & $R \$ 52$ & $R \$ 6$ & $R \$ 2$ & $\mathrm{R} \$ 7$ & $R \$ 243$ & $R \$ 9.370$ \\
\hline Total & $\mathrm{R} \$ 3.755$ & $\mathrm{R} \$ 19.251$ & $\mathrm{R} \$ 4.050$ & $\mathrm{R} \$ 12.227$ & $R \$ 6.692$ & $\mathrm{R} \$ 158.409$ \\
\hline
\end{tabular}

Quadro 3.2.2: Territorialização do financiamento fiscal do desenvolvimento urbano por região, 2000 a 2016. Valores liquidados, em milhões. Ano referência de valores: 2016. Fonte: Sistema Integrado de Planejamento e Orçamento, Ministério do Planejamento, Desenvolvimento e Gestão do Governo Federal. Elaboração nossa.

Ainda, tratamos de refletir sobre uma destinação média de recursos fiscais federais aos municípios brasileiros, ou seja, R\$2.799.915 por município. Essa média simples (R\$9.147.322.021 por 3.267 municípios) considera apenas o gasto territorializado, o que pode significar a subvalorização dos valores reais. Certamente importante parcela desses recursos federais ainda deveria ser compreendida em associação à participação dos demais entes federados, estados e/ou municípios, via contrapartidas financeiras, por exemplo. É notório que aproximados R\$3 milhões possuem baixa capacidade de estruturação urbana, dados os custos associados à provisão de infraestrutura urbana e habitacional. Os leitores que estudam as 
metrópoles brasileiras certamente notarão que se trata de um baixo quantitativo médio, e com razão: o município de São Paulo prevê destinação de cerca de $\mathrm{R} \$ 2$ bilhões de reais de seus recursos próprios apenas para o subsídio da tarifa de transporte público para o ano de 2020, por exemplo. Sem embargo, há ainda espaço para uma ponderação, já que as metrópoles brasileiras são exceção dentre os municípios brasileiros. Relativo a isso, os recursos orçamentários federais podem ter contribuído para uma associação e coordenação entre esferas nacional e local de poder executivo. Nesses termos, os recursos oriundos do Orçamento Geral da União podem ter contribuído para a indução dos governos subnacionais em torno das políticas urbanas e habitacionais federais.

Os municípios brasileiros são desiguais entre si, tal como apresenta o PlanHab (Brasil, 2009). O tratamento do banco de dados primários pela pesquisa evidencia dimensões desse debate. O estudo detalhado da execução do Orçamento Geral da União permite verificar alguns dos municípios beneficiados pelo financiamento fiscal do desenvolvimento urbano brasileiro. A Imagem 3.2.2 apresenta a visão de satélite do (A) município de Lagoa Nova, estado do Rio Grande do Norte; (B) município Franciscópolis, estado de Minas Gerais; (C) município Nova Santa Helena, estado de Mato Grosso; (D) município Dezesseis de Novembro, estado do Rio Grande do Sul, todos mencionados pela execução orçamentária e abarcados pelo financiamento fiscal e federal do desenvolvimento urbano entre 2000 e 2016. 

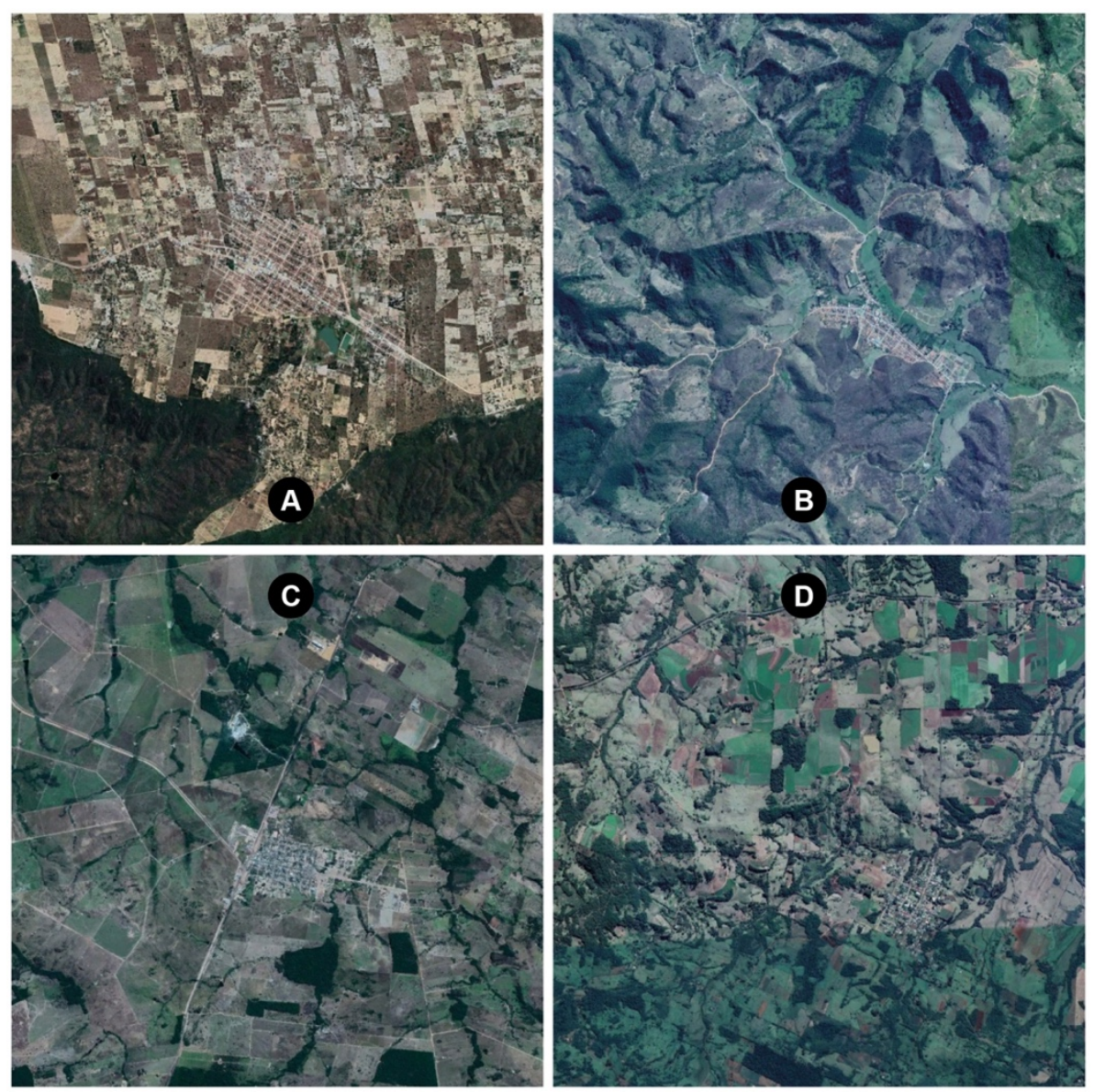

Imagem 3.2.2: Casos de territórios dos municípios das regiões Nordeste, Sudeste, Centro-Oeste e Sul beneficiados pelo financiamento fiscal do desenvolvimento urbano. Fonte: Google Earth.

Sem grandes aprofundamentos, considerando a inserção regional de cada um desses municípios, assim como aspectos morfológicos apresentados pela visão de satélite, é possível afirmar que cada uma desses municípios incorpora em si dinâmicas sociais, econômicas e políticas próprias, particulares entre si, mas também muito distintas daquelas apresentadas pelas grandes metrópoles brasileiras. Se Lagoa Nova parece estar vinculada a uma produção agrícola não latifundiária, o mesmo não parece ocorrer em Nova Santa Helena ou Franciscópolis, o que significa a diferenciação entre essas estruturas e mercados fundiários, por exemplo. Neste sentido, é factível imaginar que os produtos espaciais de diferentes organizações sociais e econômicas sejam diferentes entre si, mas também devido às condições geográficas, a exemplo da ocupação em mares de morro, típica do estado de Minas Gerais. 
Contudo, um dos casos que se destaca é o do município de Nhamundá, estado do Amazonas (Imagem 3.2.3), também afetado pelo financiamento fiscal e federal do desenvolvimento urbano. Este município organiza-se em uma ilha fluvial, próxima à divisa administrativa do estado do Amazonas, quase estado do Pará, e quase a totalidade da superfície da ilha fluvial se encontra ocupada. Considerada a inserção regional do município, mas também os aspectos morfológicos apresentados pela imagem de satélite, algumas perguntas são inevitáveis: Como se deu a produção do urbano de Nhamundá? Quais as relações sociais e econômicas existem em Nhamundá? Qual o problema urbano de Nhamundá? e tantas outras. Tendencialmente, aparte este caso ao acaso, é possível imaginarmos um município pobre no qual a administração pública representa um de seus setores econômicos mais expressivos, responsável por significativa parcela do emprego formal e renda dessa população. ${ }^{368}$ Associado a isso, o nosso estudo identifica que, entre 2002 e 2006, cerca de $R \$ 1,5$ milhão oriundo do Orçamento Geral da União foi empenhado e liquidado em prol do financiamento do desenvolvimento urbano no município de Nhamundá.

A execução do Orçamento Geral da União aponta que R\$239.049,18 foram destinados a obras de contenção de enchentes; $R \$ 594.543,89$ ao saneamento básico para controle de agravos; R\$602.374,95 à implantação, ampliação ou melhoria de sistema público de esgotamento sanitário para a prevenção e controle de agravos neste município. As ações promovidas no município de Nhamundá, financiadas por recursos fiscais federais, nos dão uma ideia das demandas desse território. As demandas, ou o aparente problema urbano de Nhamundá, em nada surpreendem, dado que o saneamento básico é um dos serviços urbanos mais precários no país, e a drenagem urbana deve ser questão recorrente em planícies fluviais. Como em tantos outros lugares, esses problemas, associados a uma urbanização precária característica do século XX brasileiro, ainda persistem.

\footnotetext{
368 Segundo informações apresentadas pelo IBGE, o município de Nhamundá possui uma população de 18.278 habitantes. Além disso: "Em 2017, o salário médio mensal era de 1.5 salários mínimos. A proporção de pessoas ocupadas em relação à população total era de 4.2\%. Na comparação com os outros municípios do estado, ocupava as posições 45 de 62 e 41 de 62, respectivamente. Já na comparação com cidades do país todo, ficava na posição 4770 de 5570 e 5395 de 5570, respectivamente. Considerando domicílios com rendimentos mensais de até meio salário mínimo por pessoa, tinha $56.5 \%$ da população nessas condições, o que o colocava na posição 3 de 62 dentre as cidades do estado e na posição 261 de 5570 dentre as cidades do Brasil". Informações disponíveis em: <https://cidades.ibge.gov.br/brasil/am/nhamunda/panorama>, consultado em novembro de 2019.
} 


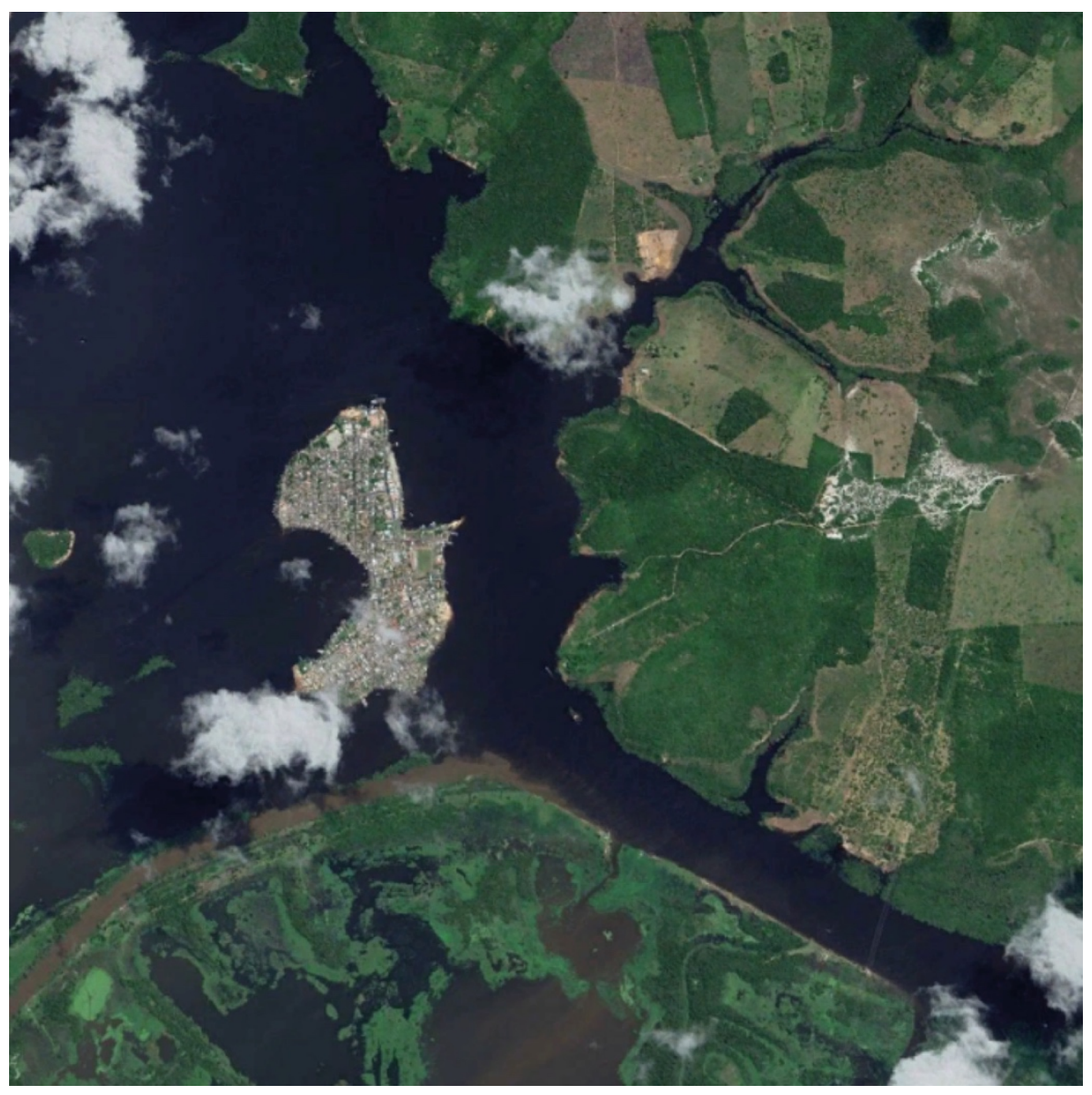

Imagem 3.2.3: Município de Nhamundá, Amazonas, beneficiado pelo financiamento fiscal do desenvolvimento urbano. Fonte: Google Earth.

O que surpreende, no entanto, é compreender a capilaridade da atuação estatal em território nacional, organizada a partir de um sistema federativo composto por 5.560 municípios, 26 estados, 1 distrito federal e a União. A articulação federativa ainda permite, apesar de todas as limitações já debatidas por este trabalho, o atendimento, mesmo que parcial ou descontínuo, das necessidades urbanas de um município pobre do norte brasileiro. Isso é evidência da solidariedade presente na organização territorial do poder brasileira, ${ }^{369}$ a partir da qual, após a concentração da riqueza pública por esfera federal, os recursos são redistribuídos com vistas à dissolução de precariedades, desigualdades e universalização do acesso a direitos.

\footnotetext{
${ }^{369}$ Agradecemos à professora Maria do Livramento Miranda Clementino pelas observações apresentadas durante o XVIII Enanpur, maio de 2019.
} 
Em termos econômicos, esse fenômeno reflete a importância da atuação estatal, do fundo público, para a articulação de projetos e investimentos, mesmo em regiões economicamente deprimidas, onde o setor produtivo da construção civil possuiria baixa ou inexistente atuação. A articulação das dimensões social e econômica, intrínsecas ao financiamento fiscal do desenvolvimento urbano, manifesta-se na produção de infraestruturas urbanas e habitacionais em municípios pobres, possível a partir da redistribuição da riqueza socialmente produzida, possível a partir da atuação estatal. É inevitável retomarmos Francisco de Oliveira e Maria da Conceição Tavares, expoentes da sociologia e ciências econômicas brasileiras, que verificam a centralidade da atuação estatal para a integração do territorial nacional, para a expansão das forças produtivas capitalistas e interiorização do desenvolvimento econômico no país. Em paralelo, retomarmos Marta Arretche, que demonstra a trajetória de redução incremental das desigualdades brasileiras, também orientada pela avaliação do acesso aos serviços urbanos básicos, fenômeno que se associa à relevância da União no sistema federativo, e o financiamento fiscal do desenvolvimento urbano brasileiro parece iluminar processos por trás dessa trajetória. Ermínia Maricato, por sua vez, relembra que as grandes metrópoles, já desde a década de 1980, não concentram o crescimento urbano brasileiro. Tendo em mente a ampliação do financiamento do desenvolvimento urbano brasileiro no início do século XXI e considerando os recursos oriundos do FGTS, SBPE e OGU, a professora debate a importância de compreender as transformações e processos decorrentes nas cidades do país, em parte conduzidas a partir da aplicação desses fundos. ${ }^{370}$ Interpretações possíveis para a imagem 3.2.1 estão ancoradas nesses debates, aqui ilustrados por meio de quatro intelectuais brasileiros.

Em específico e em relação ao financiamento fiscal da Habitação (Imagem 3.2.4), ao menos 1.543 municípios foram beneficiados pela liquidação de recursos oriundos do Orçamento Geral da União. Vale reforçar, esse número reflete a execução orçamentária passível de territorialização, e esse número deve estar subestimado. A título de exemplo, entre 2012 e 2016 não é possível territorializar o financiamento fiscal da Habitação, o que não significa que

\footnotetext{
370 Exposição realizada por Ermínia Maricato, encontro "O setor imobiliário residencial no atual ciclo de retração no Brasil" promovido pelo LABHAB-FAU-USP, 29 de outubro de 2019.
} 
os subsídios destinados ao PMCMV não exerceram influência sobre o desenvolvimento urbano brasileiro, ou que são desprovidos de uma alocação territorial.

Em relação ao financiamento fiscal do Saneamento Básico (Imagem 3.2.5), destaca-se a importância da atuação federal para a ampliação dessa rede de infraestruturas e serviços principalmente na região Nordeste, afirmação assertiva graças à ampla territorialização do gasto público possível para este eixo entre 2000 e 2011.

A respeito do financiamento fiscal da Mobilidade Urbana (Imagem 3.2.6), sobressai-se a região Sul enquanto principal beneficiada. O estudo detalhado da execução orçamentária aponta para a importância da Empresa de Trens Urbanos de Porto Alegre S.A, unidade orçamentária federal, para a execução desses recursos. Tal correlação denota a importância que uma empresa pública, responsável por sua própria programação orçamentária, pode assumir para a alocação territorial dos recursos financeiros, importância expressa especialmente para o período de 2008 a $2012 .{ }^{371}$

Em termos do financiamento fiscal da Energia Elétrica (Imagem 3.2.7), a territorialização possível do gasto público é mínima, uma vez que boa parte dos recursos foram operados pelo BNDES. A opacidade em torno da alocação territorial desses recursos não deve ser menosprezada, mesmo que se tratando de um serviço quase universalizado, pois ainda há de se pensar na manutenção e qualidade desses serviços, e sobre o controle social desses recursos.

Relativo ao financiamento fiscal da Infraestrutura Urbana (Imagem 3.2.8), é importante retomar que se trata de um eixo do desenvolvimento urbano que congrega um montante liquidado relativamente baixo. Contudo, esses recursos se distribuem entre, ao menos, 1.876 municípios, o que levanta a hipótese sobre o perfil de obras abarcadas por esse eixo, tendencialmente de menor custo.

A respeito do financiamento fiscal do Planejamento e Gestão Pública (Imagem 3.2.9), destaca-se a relevância financeira incorporada pela região Sul, concentrando R\$937.584.226. Contudo, ao passo que o município de Aparecida de Goiânia concentra ao menos R\$12 milhões

\footnotetext{
${ }^{371}$ Agradecemos aos comentários de Nicholas Zbigniew Pretto Kaminski, pesquisador grupo de pesquisa CNPq "Produção do espaço urbano e finanças contemporâneas: o papel do fundo público".
} 
de reais liquidados, o município de Tururu parece concentrar apenas $\mathrm{R} \$ 3.808$ de recursos liquidados, o que aponta para a desigual distribuição de recursos entre as diferentes jurisdições da mesma região. Vale lembrar, no Brasil as desigualdades intrarregionais ou municipais são ainda maiores do que as desigualdades regionais.

Por fim, no que diz respeito às Operações Especiais, seria possível territorializar apenas os recursos financeiros destinados ao metrô de Brasília nos anos de 2000 e 2001, o que denota limites em torno da avaliação deste eixo do desenvolvimento urbano, também substancialmente operada a partir do sistema bancário. Neste sentido, não é apresentada cartografia sobre as Operações Especiais.

Concluindo, mesmo se consideradas as fragilidades associadas ao financiamento fiscal do desenvolvimento urbano, ainda é possível debater a relevância de atuação estatal para a compreensão do desenvolvimento urbano brasileiro, e suas decorrências para todo o território nacional. O fato de apenas $4 \%$ do financiamento fiscal do desenvolvimento urbano estar territorializado, e mesmo assim abarcar um total de 3.267 municípios, apenas reforça esse argumento. A fragilidade dos dados, contudo, pode impedir novos avanços interpretativos a partir da execução do Orçamento Geral da União. Dotar a execução do gasto público de categorias territoriais, que efetivamente permitam a territorialização do financiamento do urbano, contribuiria para avanços, seja em termos de atuação estatal - políticas públicas - , seja em termos do entendimento sobre a relação entre atuação estatal e urbano a partir das finanças públicas. Dotar a administração de processos e procedimentos, organizados em um sistema, seria imprescindível. A territorialização do gasto público possibilitaria estudos sobre tendências e comportamentos relativos à distribuição espacial desses recursos financeiros, a avaliação e planejamento de atuação estatal.

De qualquer modo: Como melhor compreender e qualificar a atuação estatal frente ao desenvolvimento urbano? Como melhor compreender as relações entre desenvolvimento urbano, atuação estatal e concentração da riqueza no país? A seção 3.3 do presente trabalho avança sobre essas questões, mas por meio de estudo de caso único. 


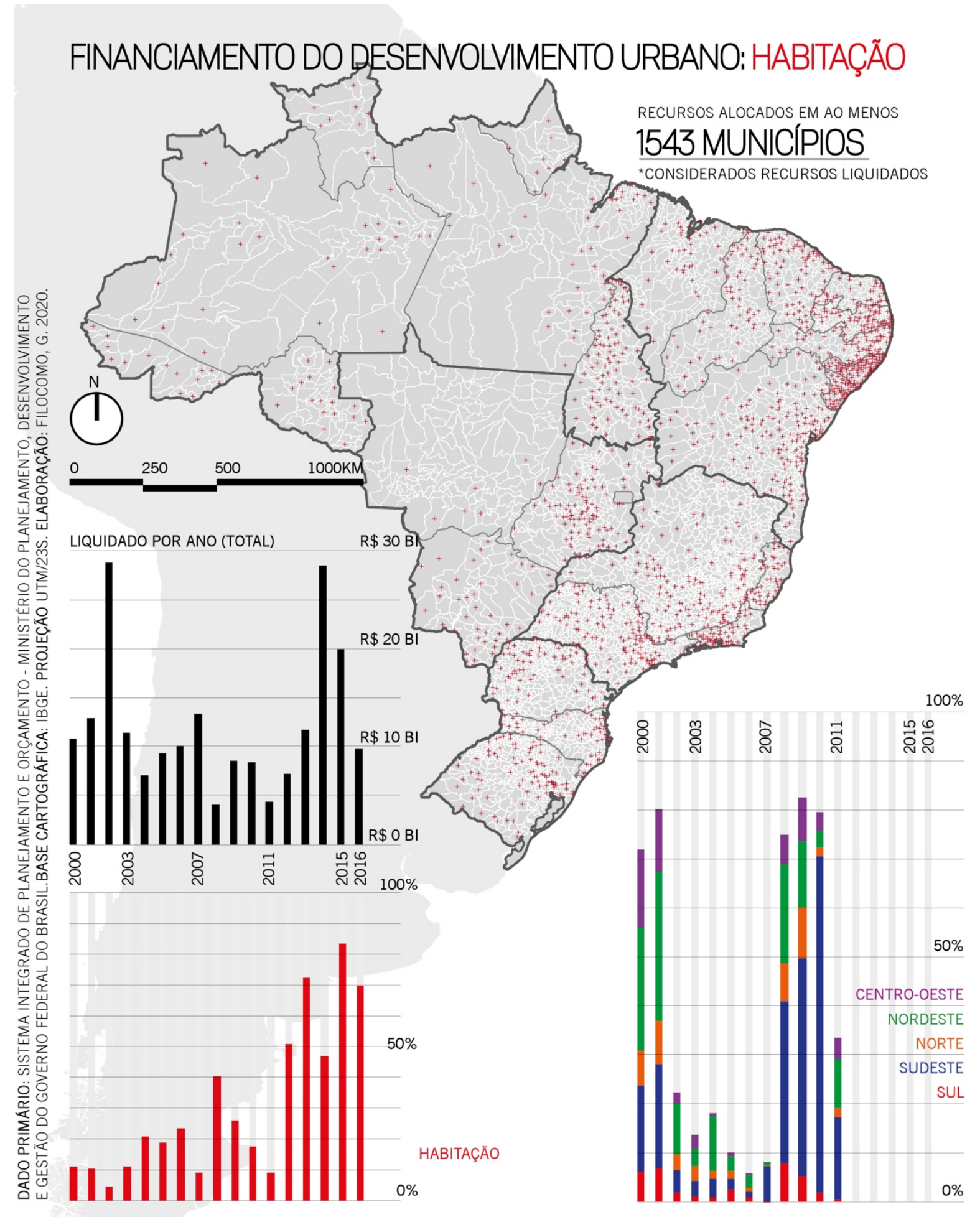

Imagem 3.2.4: Financiamento fiscal do desenvolvimento urbano entre 2000 e 2016: alocação territorial dos gastos com Habitação, alocação organizada por município. Elaboração nossa. 


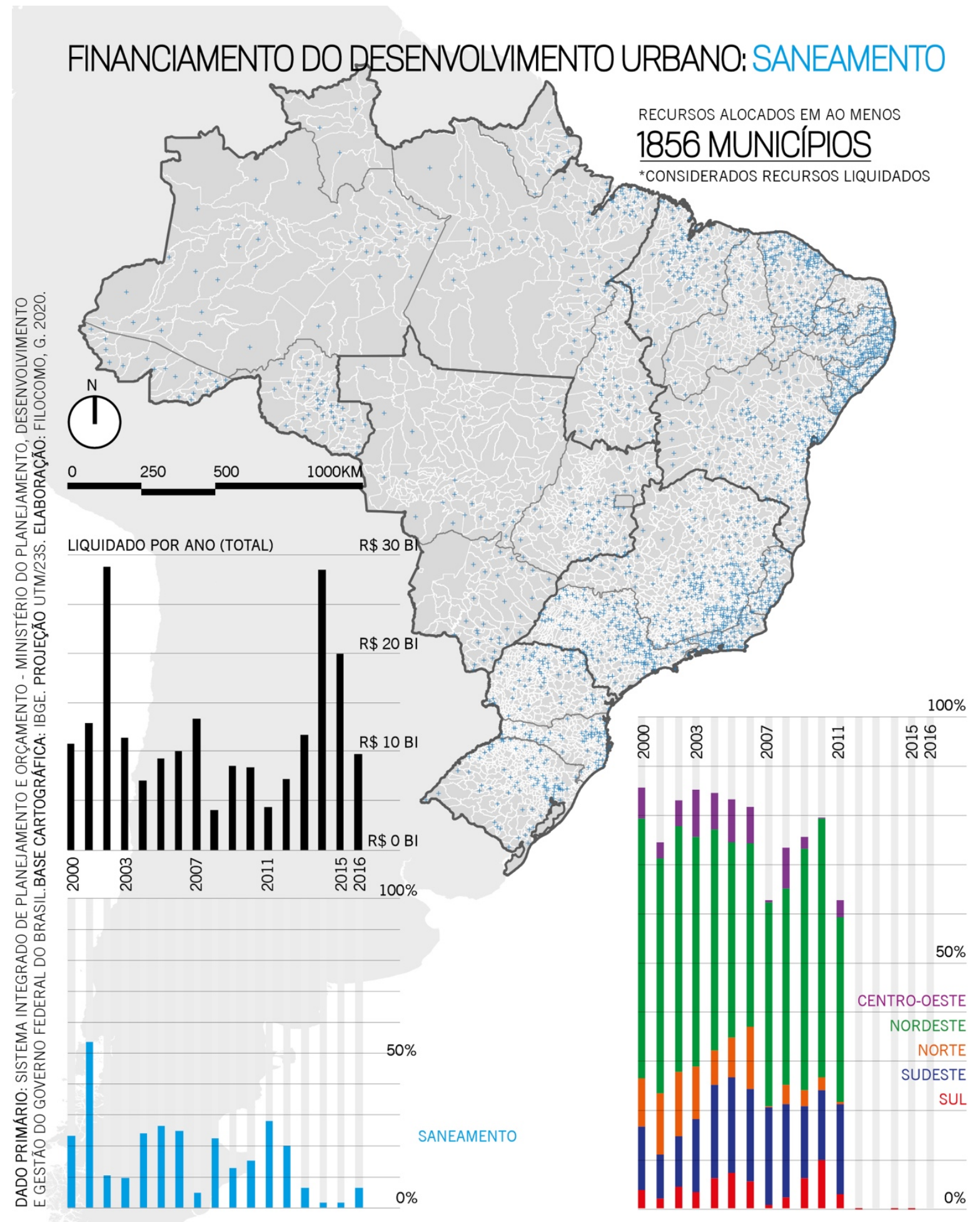

Imagem 3.2.5: Financiamento fiscal do desenvolvimento urbano entre 2000 e 2016: alocação territorial dos gastos com Saneamento Básico, alocação organizada por município. Elaboração nossa. 


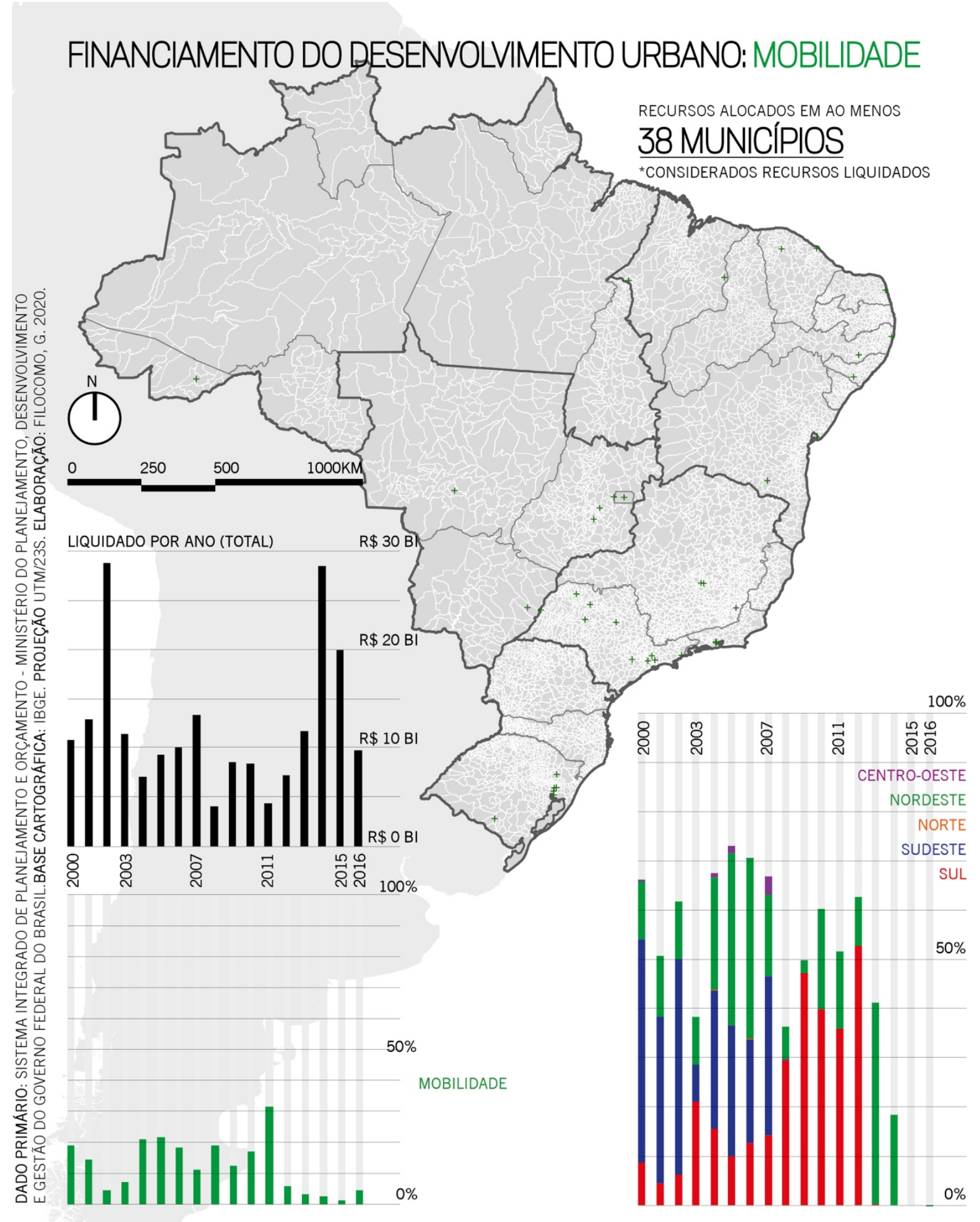

Imagem 3.2.6: Financiamento fiscal do desenvolvimento urbano entre 2000 e 2016: alocação territorial dos gastos com Mobilidade Urbana, alocação organizada por município. Elaboração nossa. 


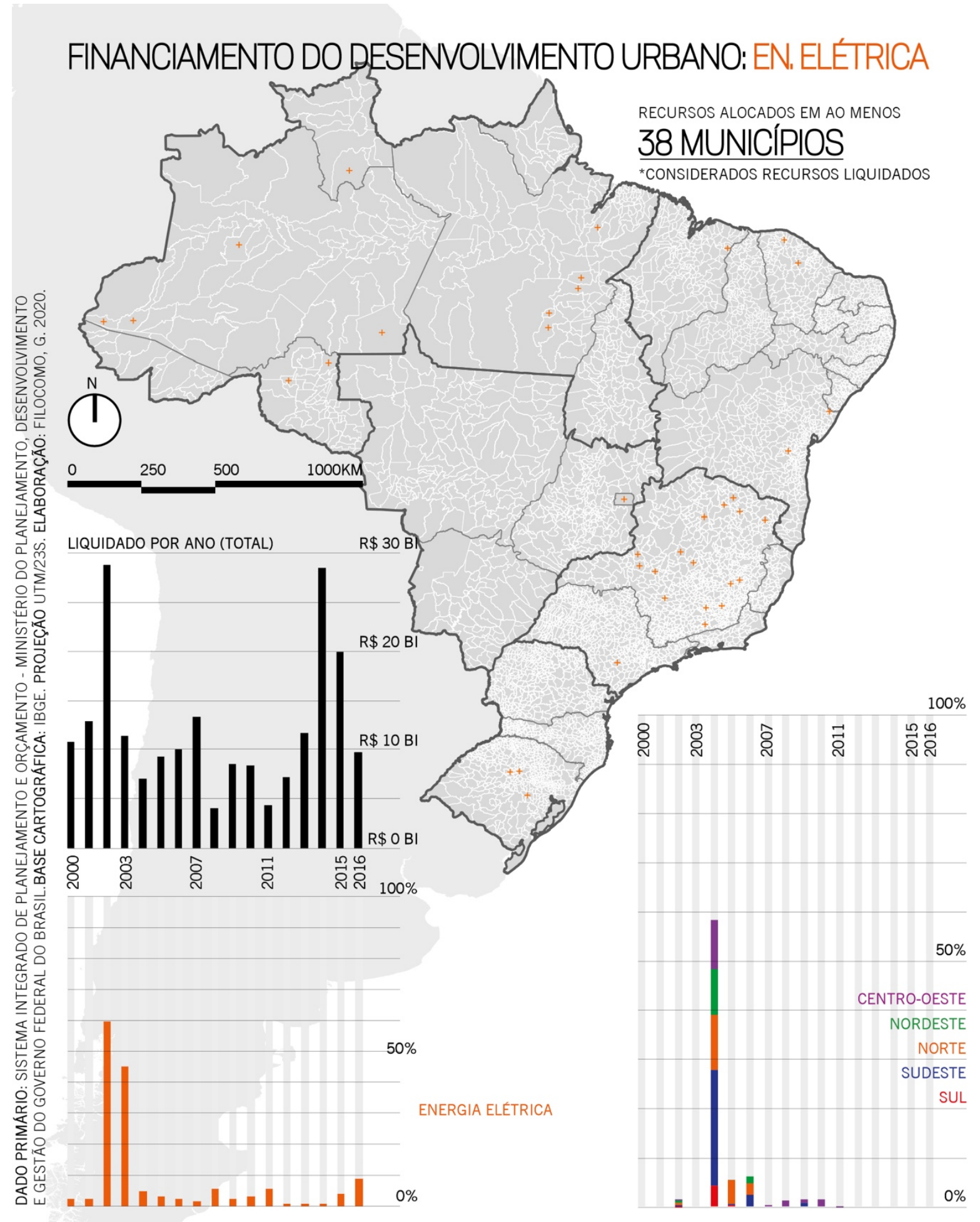

Imagem 3.2.7: Financiamento fiscal do desenvolvimento urbano entre 2000 e 2016: alocação territorial dos gastos com Energia Elétrica, alocação organizada por município. Elaboração nossa. 


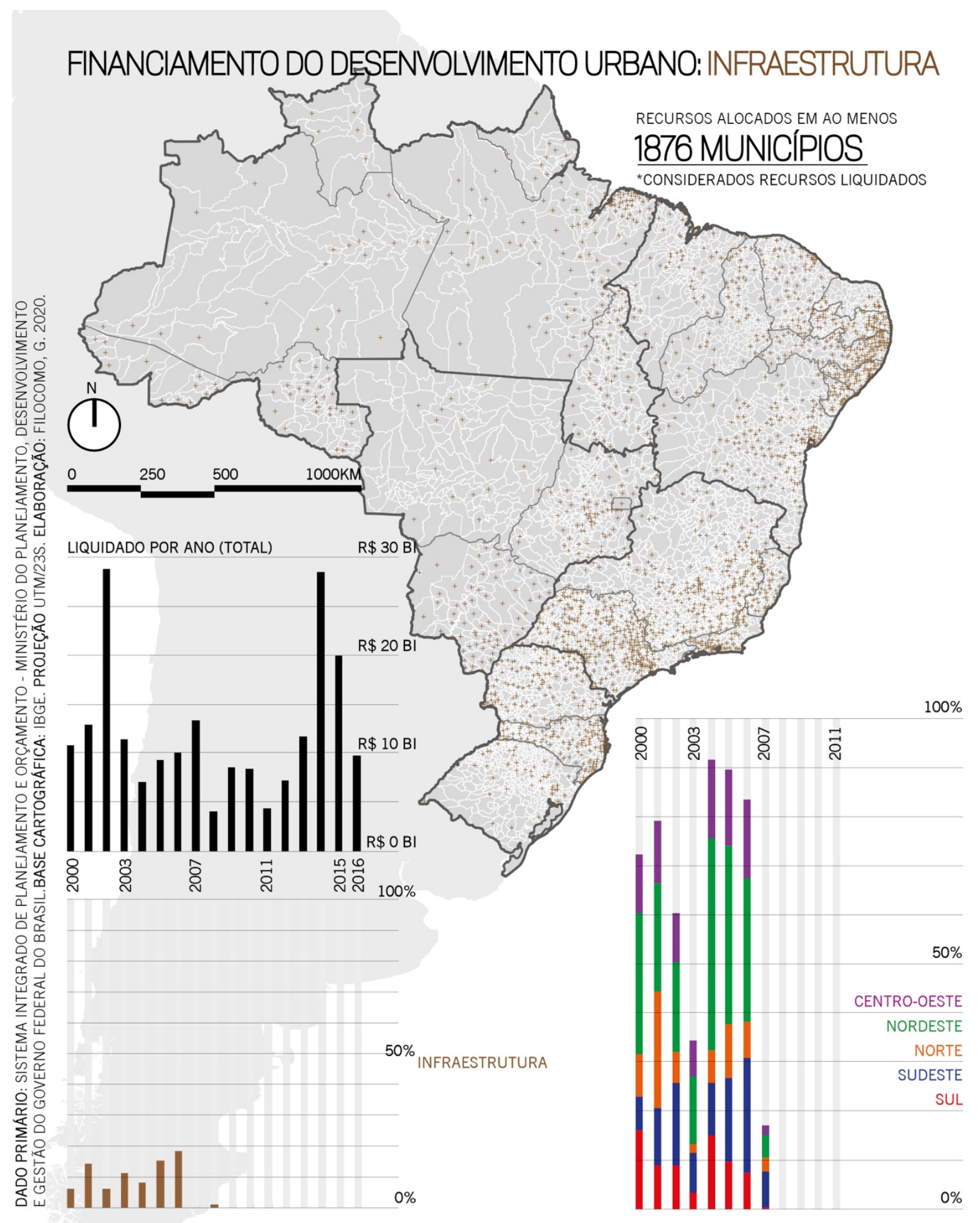

Imagem 3.2.8: Financiamento fiscal do desenvolvimento urbano entre 2000 e 2016: alocação territorial dos gastos com Infraestrutura Urbana, alocação organizada por município. Elaboração nossa. 


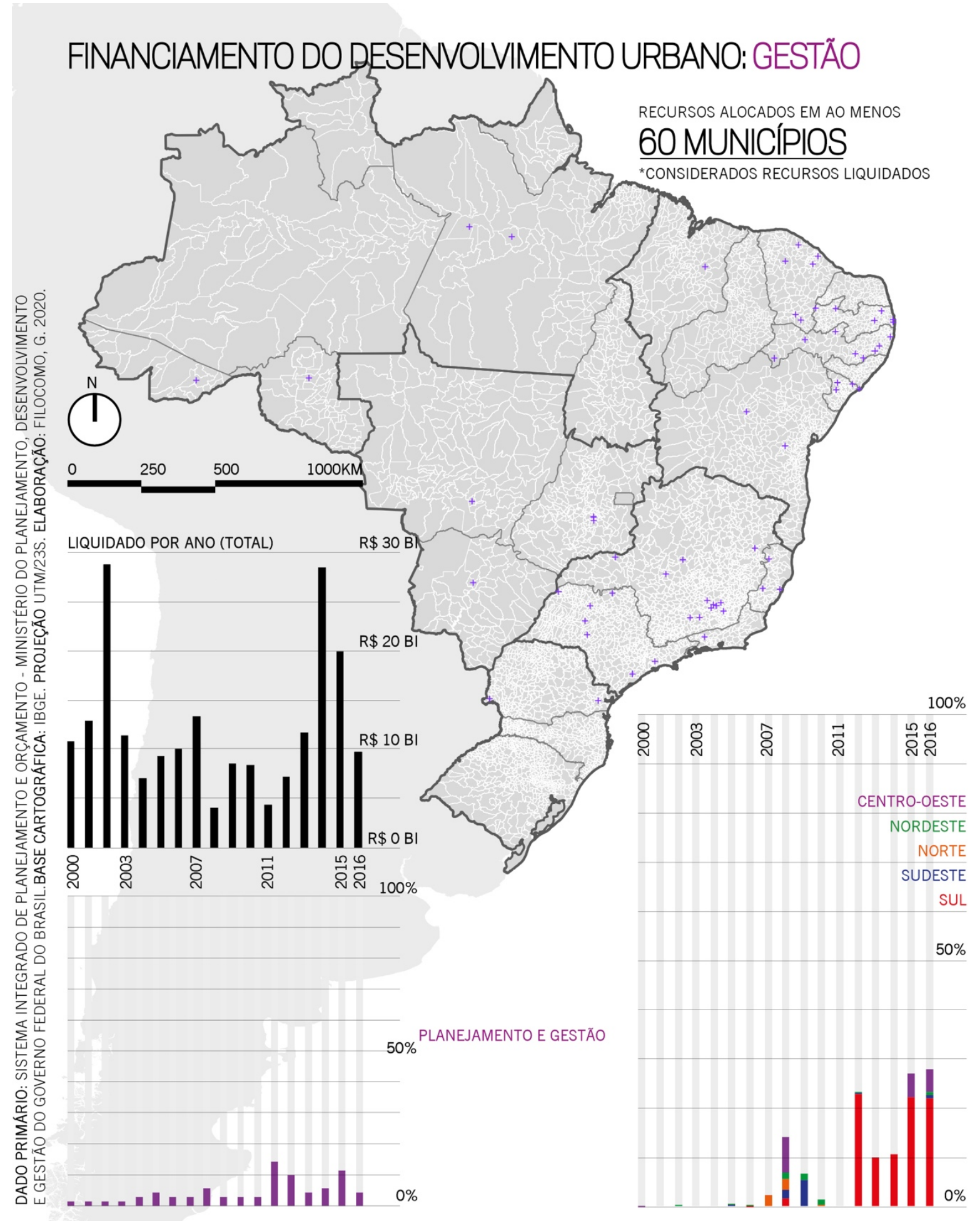

Imagem 3.2.9: Financiamento fiscal do desenvolvimento urbano entre 2000 e 2016: alocação territorial dos gastos com Planejamento e Gestão Pública, alocação organizada por município. Elaboração nossa. 


\subsection{Execução descentralizada do financiamento fiscal, o caso do município de São Paulo ${ }^{372}$}

A presente seção debate o papel da cooperação interfederativa ${ }^{373}$ em prol do desenvolvimento urbano, ou execução descentralizada ${ }^{374}$ do financiamento fiscal do desenvolvimento urbano, a partir da receita realizada ${ }^{375}$ do município de São Paulo para o período de 2003 a 2016. Ou seja, trata da participação de esferas federal e estadual no financiamento do desenvolvimento urbano da capital paulista por meio das transferências fiscais interfederativas.

É ponto pacífico que as transferências fiscais, de um modo geral, significam uma oportunidade à cooperação entre as esferas do Executivo, União, estados e municípios, e possuem impacto decisivo sobre as receitas municipais, ampliando as capacidades do gasto

local, mas também reduzindo desigualdades entre jurisdições, ou desigualdades horizontais. ${ }^{376}$ Não é demasiado relembrar que a União é ainda o ente federativo concentrador de recursos

\footnotetext{
372 Esta seção é beneficiada pelos comentários de Luciana de Oliveira Royer e Fabio Pereira dos Santos, bem como da experiência adquirida a partir do XXXVI International Congress of the Latin American Studies Association, 2018, Barcelona.

A presente seção também se beneficia dos debates e observações apresentadas no âmbito da disciplina FLS6359 - Instituições Políticas e Desigualdade: Teorias e Explicações - 1S2018, ministrada pela professora doutora Marta Arretche, programa de pós-graduação Ciência Política da Universidade de São Paulo. Agradecemos a Lucas Piaia Petrocino pelo apoio durante a sistematização dos dados primários.

${ }^{373}$ Entende-se que as transferências de recursos financeiros, ou transferências fiscais, entre entes federados é evidência de uma cooperação entre entes federados, ou cooperação interfederativa.

$374 \mathrm{O}$ acesso e execução dos recursos federais ou estaduais pelos municípios é entendida enquanto execução descentralizada desses recursos financeiros. A execução de recursos financeiros federais por estados também pode ser entendida enquanto execução descentralizada desses recursos, ou execução descentralizada de políticas públicas. A transferência de recursos financeiros entre entes federados pode estar condicionada a regras federais. $\mathrm{O}$ acesso por governos subnacionais aos recursos financeiros federais pode estar condicionado a regras. Isso significa a capacidade de esfera federal na formulação, regulamentação e indução em torno de políticas públicas, mesmo que as políticas e recursos financeiros sejam executadas por governos subnacionais. Trata-se da capacidade de indução federal.

375 Receita realizada, nesses termos e referente à administração municipal de São Paulo, corresponde à arrecadação própria e é a referência usual para a elaboração de Relatórios de Responsabilidade Fiscal, por exemplo. O Relatório de Receita Líquida apresenta a previsão de receita, a previsão atualizada de receita, e a receita realizada municipal. É praxe nos estudos orçamentários sobre a administração municipal de São Paulo, assim, a comparação entre a receita realizada e a execução orçamentária, por exemplo, ainda que levando-se em consideração essa especificidade contábil. Agradecemos aos comentários da professora doutora Ursula Dias Peres. Para a presente seção, a expressão receita realizada e receita municipal assumem valores semelhantes.

${ }^{376}$ Cf. Centro de Estudos da Metrópole/Cebrap; Ministério das Cidades, 2012.
} 
financeiros, ${ }^{377}$ mesmo após a repartição constitucional obrigatória;; 378 o fenômeno da municipalização das atribuições urbanas; ${ }^{379}$ a afetação da execução de políticas públicas pela regulação e repasses interfederativos; ${ }^{380}$ e por entendermos o desenvolvimento urbano enquanto competência concorrente, devendo ser pensada coletivamente pelas diferentes esferas do poder executivo. ${ }^{381}$ Desse modo, avaliações acerca da execução descentralizada dos recursos fiscais federais também subsidiam debates sobre as desigualdades intraurbanas e territoriais.

Dito isso, relativo a finanças públicas e desenvolvimento urbano, primordialmente esta seção objetiva avançar sobre a relação estabelecida entre (i) atuação estatal; (ii) riqueza pública, ou riqueza das jurisdições;; ${ }^{382}$ e (iii) urbano, nesta seção compreendido a partir das dimensões da precariedade urbanística e habitacional mas também a partir das desigualdades socioterritoriais, ou seja, com atenção ao problema urbano. ${ }^{383}$ A questão de fundo é investigar a causalidade entre riqueza pública e atuação estatal frente ao desenvolvimento urbano a partir de estudo de caso único, também com vistas a qualificar a relação entre atuação estatal e urbano no país. De maneira secundária, busca-se articular a atuação estatal em prol do desenvolvimento urbano à conformação de arranjos institucionais a partir do estudo das finanças públicas, assim como ao debate sobre as desigualdades brasileiras. ${ }^{384}$

\footnotetext{
377 Ver MacDowell, 2007, por exemplo.

378 Ver Afonso, 2017, por exemplo.

${ }^{379}$ Ver Martins, 2004, por exemplo.

380 Ver Martins, 2007; Arretche, 2012, por exemplo.

${ }^{381}$ Ver Royer, 2013, por exemplo.

382 Por jurisdições podemos entender entes federados.

${ }^{383}$ A conceituação de problema urbano é apresentada anteriormente por esta dissertação.
}

A questão urbana também deve ser pensada a partir da perspectiva metropolitana. Recursos aplicados pelas prefeituras com vistas a prestação de serviços municipais podem ser consumidos por moradores de outros municípios (Singer, 1980; pp.143-4), por exemplo. No entanto, enquanto aproximação ao problema, optamos aqui pelo estudo isolado do orçamento do município de São Paulo.

${ }^{384}$ De modo secundário, este trabalho busca contribuir para os estudos sociais sobre as desigualdades a partir do estudo do espaço, entendendo o espaço não apenas enquanto reflexo das desigualdades, mas também enquanto fundamento de desigualdades e dimensão à compreensão daquilo que se refere ao urbano e ao território. Ou seja, o presente trabalho também se associa ao debate sobre relação estabelecida entre riqueza das jurisdições e redução das desigualdades no acesso aos serviços urbanos básicos. 
O presente estudo se justifica porque o aceso a serviços básicos se relaciona com a desigualdade de renda entre indivíduos, mas aparentemente com a concentração da riqueza por jurisdições, assumindo assim caráter territorial nacional. Dessa maneira, avançar sobre a relação estabelecida entre atuação estatal, riqueza das jurisdições e urbano é relevante ao debate sobre o problema urbano. A priori, são levantadas duas possibilidades:

(i) Diante de consolidada execução descentralizada do financiamento fiscal federal do desenvolvimento urbano, há contra-evidência sobre a força explicativa da riqueza das jurisdições para a compreensão do problema urbano, em especial no que se refere às desigualdades socioterritoriais no acesso a serviços urbanos básicos;

(ii) Na ausência de consolidada execução descentralizada do financiamento fiscal federal do desenvolvimento urbano, é reforçada a força explicativa da riqueza das jurisdições para a compreensão do problema urbano, em especial no que se refere às desigualdades socioterritoriais no acesso a serviços urbanos básicos. É, assim, indicada causalidade parcial. ${ }^{385}$

Essa investigação justifica-se, porque, apesar da trajetória de expansão das coberturas de serviços essenciais no Brasil ser marcada pela associação entre riqueza das jurisdições, renda da população e oferta de serviços essenciais (Arretche, 2015; p.197), não parece ser possível determinar se há causalidade entre esses elementos a partir de estudos de "grande n", tal como debatido pela seção 3.2 da presente dissertação. Esta pretende ser a contribuição preliminar de estudo de caso único apresentado adiante. ${ }^{386}$

\footnotetext{
385 Já debatido, as transferências fiscais entre entes federados podem ampliar as capacidades do gasto local, mas também reduzir desigualdades entre jurisdições. Desse modo desenvolvem-se as possibilidades aqui apresentadas. ${ }^{386}$ Preliminar porque seria necessário verificarmos também os investimentos realizados pelo governo federal e pelo governo do estado de são paulo sobre o território do município de São Paulo. As três esferas do executivo estão debruçadas sobre o mesmo território. A administração direta e indireta, federal, estadual e municipal, deveriam ser consideradas. Destaca-se também a relevância de melhor entender os subsídios (do transporte urbano, por exemplo) e o custeio público a partir do desenvolvimento urbano (com destaque à zeladoria e limpeza urbana); assim como o papel das transferências reguladas e desvinculadas no financiamento do desenvolvimento urbano, a exemplo da Quota-Parte do ICMS. Para estudos comparados ressaltamos que a avaliação da cooperação via transferências interfederativas e receitas municipais exige um maior cuidado. Sobre isso, deve ser considerada a relação entre (i) diferentes capacidades administrativas e tributárias; (ii) relevância dos recursos estadual e federal para a composição das receitas avaliadas; (iii) a vinculação dos recursos públicos; e (iv) a distribuição populacional e das precariedades urbanas e habitacionais, por exemplo. Tal ponderação deve ser levada em consideração também para a leitura do presente estudo. Agradeço aos comentários de Fabio Pereira dos Santos.
} 


\subsubsection{O caso do município de São Paulo}

Para o período de 2003 a 2016, cerca de 52\% da receita municipal é composta por arrecadação própria, denotando a autonomia fiscal e a capacidade de gastos incorporada pelo poder executivo da capital paulista durante as últimas décadas, ${ }^{387}$ também se em comparação com o conjunto dos municípios do país. ${ }^{388}$ Entre 2003 e 2016 cerca de 39\% de receita municipal paulistana é composta por recursos transferidos por outros entes federados (Quadro 3.3.1; Gráfico 3.3.1). Mesmo para o município de São Paulo é evidente a importância que a cooperação interfederativa via transferência fiscal assume na composição da receita local, mesmo se tratando de município particular que concentra mais de $10 \%$ do PIB nacional, em acordo com o Instituto Brasileiro de Geografia e Estatística, o que ratifica estudo aqui apresentado.

\begin{tabular}{lll}
\hline Ano & Receita Realizada Município São Paulo & $\begin{array}{l}\text { Transferências Intergovernamentais e de } \\
\text { Convênios Interfederativos }\end{array}$ \\
\hline 2003 & $R \$ 23.479 .658 .331,42$ & $R \$ 9.993 .845 .395,88$ \\
2004 & $R \$ 26.387 .451 .009,90$ & $R \$ 11.697 .914 .902,87$ \\
2005 & $R \$ 28.483 .930 .078,66$ & $R \$ 11.790 .653 .680,97$ \\
2006 & $R \$ 31.550 .224 .833,62$ & $R \$ 13.195 .451 .685,79$ \\
\hline 2007 & $R \$ 33.606 .741 .177,22$ & $R \$ 14.207 .286 .635,22$ \\
\hline 2008 & $R \$ 39.851 .221 .484,61$ & $R \$ 15.847 .000 .391,10$ \\
\hline 2009 & $R \$ 39.762 .903 .838,50$ & $R \$ 16.722 .901 .838,24$ \\
\hline 2010 & $R \$ 45.079 .458 .714,38$ & $R \$ 17.356 .791 .823,79$ \\
\hline 2011 & $R \$ 45.299 .067 .050,65$ & $R \$ 17.800 .665 .525,66$ \\
\hline 2012 & $R \$ 49.962 .288 .359,00$ & $R \$ 17.785 .817 .817,89$ \\
\hline 2013 & $R \$ 48.462 .823 .770,40$ & $R \$ 18.868 .377 .326,70$ \\
\hline 2014 & $R \$ 49.200 .806 .295,49$ & $R \$ 18.466 .540 .728,89$ \\
\hline 2015 & $R \$ 51.469 .459 .386,16$ & $R \$ 16.820 .482 .036,71$ \\
\hline 2016 & $R \$ 47.527 .063 .233,37$ & $R \$ 16.250 .807 .318,71$ \\
\hline$\%$ & $100 \%$ & $39 \%$ \\
\hline
\end{tabular}

Quadro 3.3.1: Receita Realizada do Município de São Paulo e a participação das Transferências Intergovernamentais e de Convênios Interfederativos. Ano referência 2016. Fonte: Prefeitura do Município de São Paulo. Elaboração nossa.

\footnotetext{
387 A partir dos dados apresentados por Barat, 1984.

${ }^{388}$ Cf. Afonso, 2017.
} 


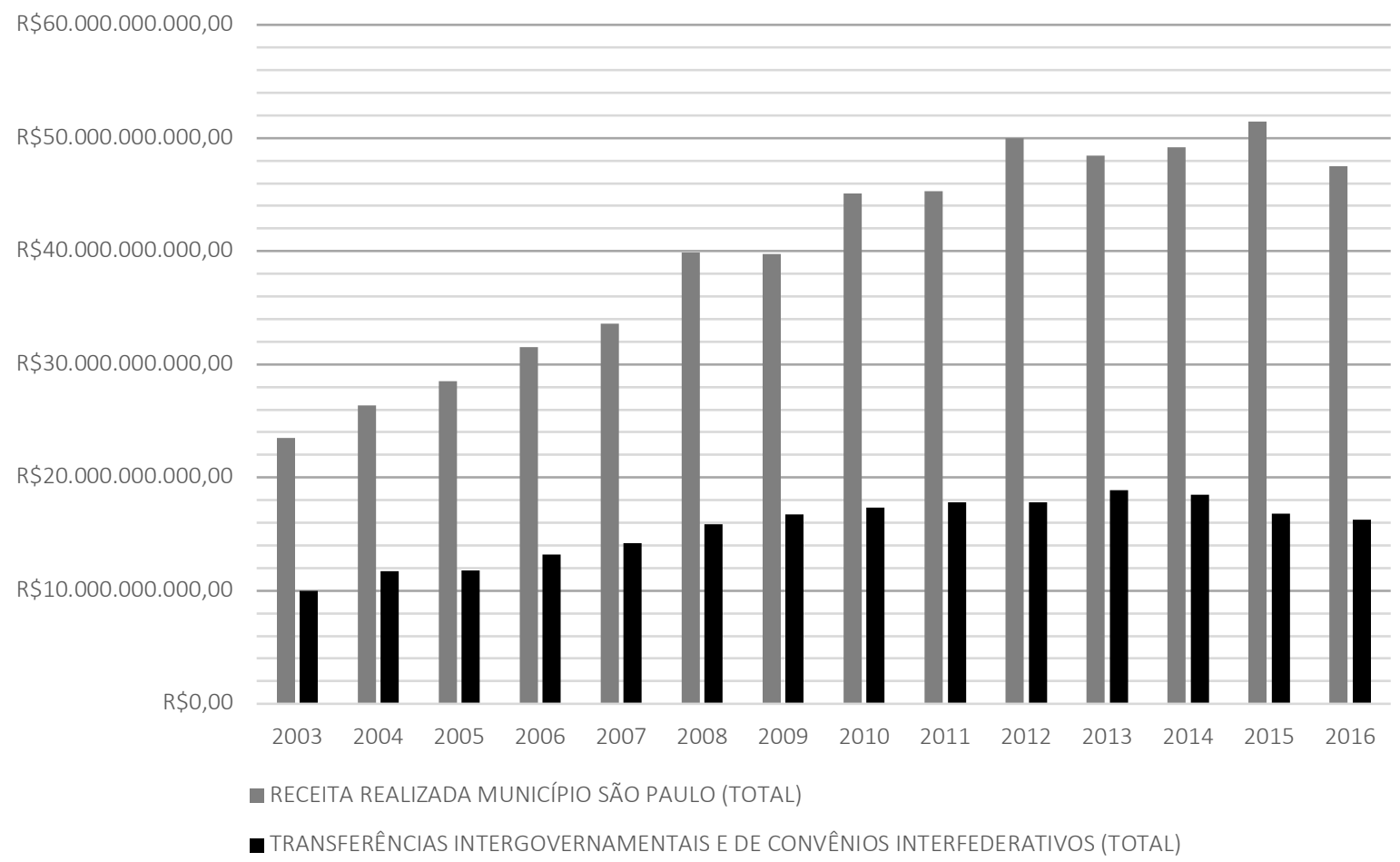

Gráfico 3.3.1: Receita Realizada do Município de São Paulo e a participação das Transferências Intergovernamentais e de Convênios Interfederativos. Ano referência 2016. Fonte: Prefeitura do Município de São Paulo. Elaboração nossa.

Para o período de 2003 a 2016, a receita realizada do município de São Paulo indica uma série de rubricas relacionadas a transferências fiscais interfederativas em prol do financiamento fiscal do desenvolvimento urbano na capital paulista (Quadro Anexo 6; Quadro Anexo 7). Após classificar as rubricas por origem do recurso (governo do estado de São Paulo; governo federal), e também pelo eixo do desenvolvimento urbano que circunscreve a rubrica (Infraestrutura Urbana; Saneamento Básico; Habitação), é construída avaliação adiante.

Segundo os dados orçamentários, a cooperação estadual em prol do desenvolvimento urbano pode ser diferenciada em três momentos: (i) 2003 a 2005, quando inexiste; (ii) 2006 a 2010, quando apresenta importante crescimento quantitativo e supera a marca dos $\mathrm{R} \$ 278$ milhões ao ano, recursos quase que totalmente destinados ao financiamento de políticas habitacionais; (iii) 2011 a 2016, quando o volume de recursos chega a superar os R\$573 milhões ao ano, e os investimentos se estruturam principalmente em torno da temática do saneamento básico, ponto controverso debatido mais adiante (Quadro 3.3.2; Gráfico 3.3.2; Quadro Anexo 6). 


\begin{tabular}{|c|c|c|c|c|}
\hline \multicolumn{5}{|c|}{$\begin{array}{l}\text { Receita realizada de Convênios e Transferências Estaduais } \\
\text { destinadas ao financiamento do desenvolvimento urbano de município de São Paulo }\end{array}$} \\
\hline Ano & $\begin{array}{l}\text { Infraestrutura } \\
\text { urbana }\end{array}$ & Saneamento Básico & Habitação & Total por ano \\
\hline 2003 & $\mathrm{R} \$-$ & $\mathrm{R} \$-$ & $\mathrm{R} \$-$ & $\mathrm{R} \$-$ \\
\hline 2004 & $\mathrm{R} \$ \mathbf{-}$ & $\mathrm{R} \$-$ & 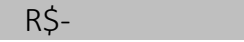 & $\mathrm{R} \$-$ \\
\hline 2005 & $R \$-$ & $\mathrm{R} \$ \mathbf{S}_{-}^{-}$ & 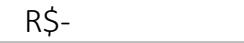 & $\mathrm{R} \$-$ \\
\hline 2006 & $R \$ 5.840 .451$ & $\mathrm{R} \$ 21.344$ & $\mathrm{R} \$ 40.498 .626$ & $\mathrm{R} \$ 46.360 .421$ \\
\hline 2007 & $R \$-$ & $R \$ 232.662$ & $\mathrm{R} \$ 196.349 .998$ & $\mathrm{R} \$ 196.582 .660$ \\
\hline 2008 & $R \$ 4.246 .280$ & $\mathrm{R} \$ 34.766$ & $\mathrm{R} \$ 144.887 .425$ & $\mathrm{R} \$ 149.168 .471$ \\
\hline 2009 & $\mathrm{R} \$-$ & $\mathrm{R} \$ 216.131$ & $\mathrm{R} \$ 278.326 .525$ & $\mathrm{R} \$ 278.542 .656$ \\
\hline 2010 & $\mathrm{R} \$-$ & $\mathrm{R} \$-$ & $\mathrm{R} \$ 189.304 .273$ & $\mathrm{R} \$ 189.304 .273$ \\
\hline 2011 & $\mathrm{R} \$-$ & $R \$ 436.587 .104$ & $\mathrm{R} \$ 87.671 .079$ & $\mathrm{R} \$ 524.258 .183$ \\
\hline 2012 & $\mathrm{R} \$-$ & $\mathrm{R} \$ 457.148 .691$ & $R \$ 116.073 .684$ & $\mathrm{R} \$ 573.222 .375$ \\
\hline 2013 & $\mathrm{R} \$$ & $R \$ 452.532 .366$ & $R \$ 31.803 .664$ & $\mathrm{R} \$ 484.336 .030$ \\
\hline 2014 & $\mathrm{R} \$$ & $\mathrm{R} \$ 406.419 .961$ & $\mathrm{R} \$ 12.753 .835$ & $\mathrm{R} \$ 419.173 .795$ \\
\hline 2015 & $\mathrm{RS}-$ & $\mathrm{R} \$ 308.108 .355$ & $R \$ 29.004 .736$ & $R \$ 337.113 .091$ \\
\hline 2016 & $R \$ 14.300 .000$ & $\mathrm{R} \$ 377.759 .336$ & $R \$ 67.006 .356$ & $R \$ 459.065 .692$ \\
\hline
\end{tabular}

Quadro 3.3.2: Receita realizada de Convênios e Transferências Estaduais destinadas ao financiamento do desenvolvimento urbano de município de São Paulo. Ano referência 2016. Fonte: Prefeitura do Município de São Paulo. Elaboração nossa.

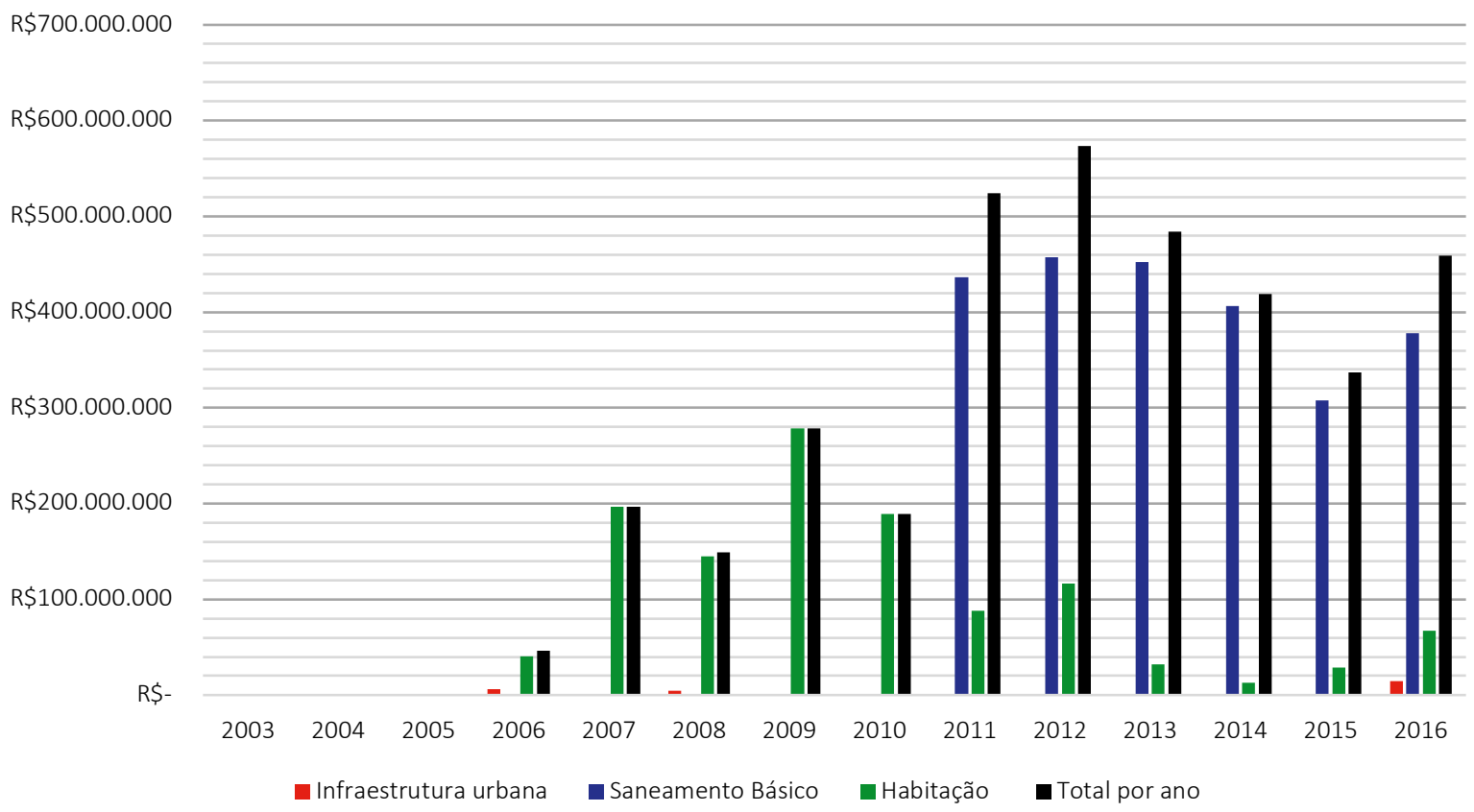

Gráfico 3.3.2: Receita realizada de Convênios e Transferências Estaduais destinadas ao financiamento do desenvolvimento urbano de município de São Paulo. Ano referência 2016. Fonte: Prefeitura do Município de São Paulo. Elaboração nossa. 
O comportamento dos repasses estaduais é substancialmente explicado por apenas quatro rubricas. ${ }^{389}$ Entre 2006 e 2009 a Secretaria Municipal e Habitação (SEHAB-PMSP) é beneficiada por convênio com a Companhia de Desenvolvimento Habitacional e Urbano (CDHU), administração indireta do Governo do Estado de São Paulo, o que significa a captação de mais de $\mathrm{R} \$ 450$ milhões pelo município. Em paralelo, um convênio estabelecido entre a SEHAB-PMSP e o Governo do Estado assegura o repasse de mais de $\mathrm{R} \$ 200$ milhões ao município de São Paulo entre 2008 e 2010. Essas duas rubricas asseguram ainda cerca de R\$120 milhões entre 2011 e 2015. Em 2010, o Governo do Estado repassa outros R\$185 milhões ao município de São Paulo, recursos captados pelo Estado junto à União no âmbito do Programa de Aceleração do Crescimento modalidade Mananciais (PAC-Mananciais). Entre 2010 e 2012 o PAC-Mananciais permite ao Governo do Estado o repasse de mais de $\mathrm{R} \$ 300$ milhões à capital paulista, destinados à promoção de saneamento integrado e urbanização e proteção aos mananciais, principalmente na região sul da cidade de São Paulo. Por fim, a cooperação estadual em prol do financiamento do desenvolvimento urbano paulistano assume novas dimensões em 2011, ano de início da operação do Fundo Municipal de Saneamento Ambiental e Infraestrutura (FMSAI). Os recursos destinados ao FMSAI superam o montante de R\$2,4 bilhões entre $2011 \mathrm{e}$ 2016, ou seja, 67\% de todos os recursos estaduais repassados ao município entre 2003 e 2016.

Contudo, é debatível a classificação dos recursos destinados ao FMSAI. ${ }^{390}$ O FMSAl é instituído pela Lei Municipal №14.934/2009 junto à Secretaria Municipal de Habitação de São Paulo, e essa regulação determina que o fundo apoie e suporte investimentos em saneamento básico, saneamento ambiental e infraestrutura urbana na capital paulista. Os recursos destinados ao FMSAI advêm de repasses efetuados pela empresa de capital misto Companhia de Saneamento Básico do Estado de São Paulo (SABESP), repasse possível a partir dos

389 (A) 2.4.7.2.03.02 - CONVÊNIO PMSP X SABESP - FUNDO MUNICIPAL DE SANEAMENTO AMBIENTAL E INF e 2.4.7.2.03.52 - CONVÊNIO PMSP X SABESP - FUNDO MUNICIPAL DE SANEAMENTO AMBIENTAL E INF; (B) 2.4.7.2.99.05 - CONVÊNIO CDHU X SEHAB; (C) 2.4.7.2.99.10 - CONVÊNIO SEHAB X ESTADO; (D) 2.4.7.2.99.07 - CT / CEF / SEHAB / MIN. CIDADES / PAC ESTADUAL / MANANCIAIS LOTES I A. Ver Quadro Anexo 6.

${ }^{390}$ As receitas oriundas do contrato de concessão/prestação de serviços públicos assinado entre a prefeitura de São Paulo, o governo do estado de São Paulo e a Sabesp, empresa de economia mista controlada pelo governo estadual, são repassadas pela Sabesp ao município de São Paulo. Deveriam, portanto, ser classificadas como receita própria da prefeitura. Entretanto, por razões políticas, à época da assinatura do contrato (2010) a prefeitura optou por classificá-la como receita de transferência estadual. Essa distorção permanece até hoje. 
rendimentos dessa empresa e relativos a 7,5\% da receita bruta obtida pela SABESP a partir da exploração dos serviços de abastecimento de água e esgotamento sanitário na cidade de São Paulo. ${ }^{391}$ Com isso, está garantida a continuidade e regularidade de repasses que alimentam o fundo, a previsão é de que o fundo gerencie quase $R \$ 17$ bilhões durante um período de 30 anos. $^{392}$ Sem embargo, os recursos destinados ao FMSAI não são exatamente uma transferência fiscal entre entes federados, mas sim um pagamento devido à municipalidade. Assim sendo, ao desconsiderar os recursos destinados ao FMSAI enquanto transferência fiscal, verifica-se que a cooperação estadual com o município de São Paulo em prol do desenvolvimento urbano apresenta uma queda substancial a partir do ano de 2011 (Gráfico 3.3.2a; Quadro Anexo 6).

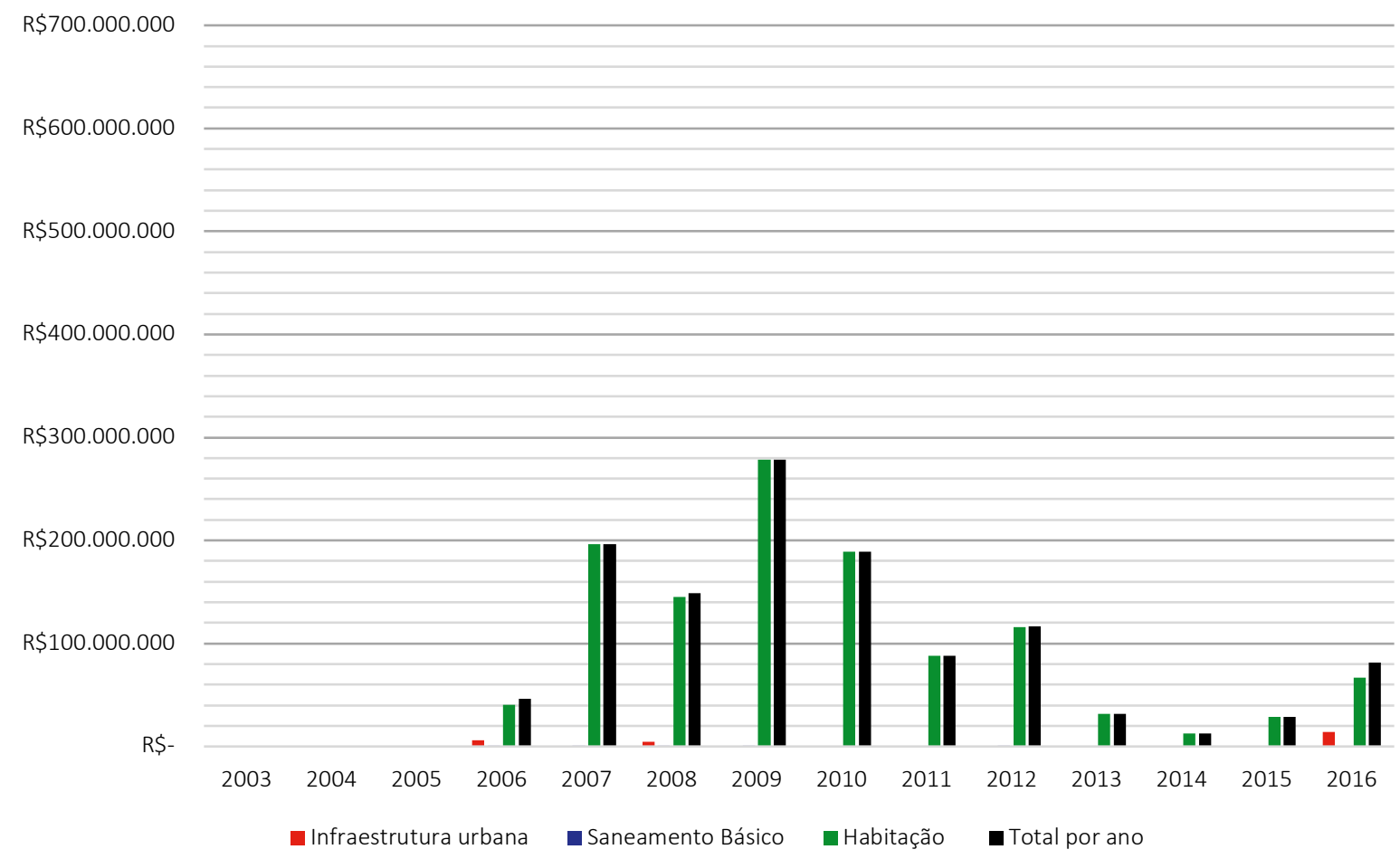

Gráfico 3.3.2a: Receita realizada de Convênios e Transferências Estaduais destinadas ao financiamento do desenvolvimento urbano de município de São Paulo - desconsiderados os recursos destinados ao FMSAI. Ano referência 2016. Fonte: Prefeitura do Município de São Paulo. Elaboração nossa.

\footnotetext{
${ }^{391}$ Conforme as disposições estabelecidas em contrato de prestação de serviços públicos firmado com o Governo do Estado de São Paulo e a SABESP em junho de 2010.

392 O FMSAl disponibiliza em seu portal eletrônico os planos anuais e a territorialização de investimentos, informando o processo administrativo, fase, contratos, escopo e total proposto em reais para cada investimento financiado por seus recursos.
} 
No que diz respeito à cooperação federal em prol do financiamento do desenvolvimento urbano paulistano, destaca-se a alta oscilação dos montantes anuais. O máximo atinge $\mathrm{R} \$ 303$ milhões em 2014, e o mínimo é de R\$22,9 milhões em 2007. Em 2003 não é verificada transferência fiscal federal destinada ao financiamento do desenvolvimento urbano, segundo receita realizada do município de São Paulo. ${ }^{393}$

As transferências federais podem ser avaliadas em três momentos, iniciados e encerrados por anos com baixos valores acumulados, mas também tratando-se de momentos compostos por anos de importante captação municipal de recursos disponibilizados pela União. São os momentos: (iv) 2003 a 2006, máximo de R\$134 milhões (2005) e mínimo de R\$23 milhões (2006), destinados principalmente ao financiamento de infraestruturas urbana e habitacional; em 2003 não há valor acumulado; (v) 2007 a 2012, quando os recursos oriundos da esfera federal estão direcionados principalmente ao tema da habitação, máximo de R\$260 milhões em 2009, mínimo de R\$22 milhões em 2007; (vi) 2013 a 2016, período em que destacase o financiamento das obras de infraestrutura urbana, mas também os recursos destinados à habitação. Entre 2013 e 2016, verifica-se o máximo de R\$303 milhões em 2014, mínimo de R\$54 milhões em 2016 (Quadro 3.3.3; Gráfico 3.3.3; Quadro Anexo 7).

\footnotetext{
${ }^{393}$ A oscilação não parece estar relacionada aos ciclos eleitorais.
} 


\begin{tabular}{|c|c|c|c|c|}
\hline \multicolumn{5}{|c|}{$\begin{array}{l}\text { Receita realizada de Convênios e Transferências Federais } \\
\text { destinadas ao financiamento do desenvolvimento urbano de município de São Paulo }\end{array}$} \\
\hline Ano & Infraestrutura urbana & Saneamento Básico & Habitação & Total por ano \\
\hline 2003 & $R \$-$ & $\mathrm{R} \$-$ & $\mathrm{R} \$-$ & $\mathrm{R} \$-$ \\
\hline 2004 & $R \$ 67.754 .085$ & $R \$ 85.299$ & $R \$ 46.035 .030$ & $\mathrm{R} \$ 113.874 .414$ \\
\hline 2005 & $\mathrm{R} \$ 85.239 .000$ & $\mathrm{R} \$-$ & $\mathrm{R} \$ 48.762 .073$ & $\mathrm{R} \$ 134.001 .073$ \\
\hline 2006 & $\mathrm{R} \$ 22.491 .236$ & $R \$ 1.309 .737$ & $\mathrm{R} \$ 179.400$ & $R \$ 23.980 .373$ \\
\hline 2007 & $\mathrm{R} \$-$ & $\mathrm{R} \$ 4.890 .711$ & $\mathrm{R} \$ 18.018 .000$ & $\mathrm{R} \$ 22.908 .711$ \\
\hline 2008 & $\mathrm{R} \$ 33.571$ & $R \$ 3.250 .211$ & $R \$ 153.899 .649$ & $\mathrm{R} \$ 157.183 .431$ \\
\hline 2009 & 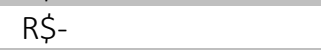 & $\mathrm{R} \$-$ & $R \$ 260.230 .444$ & $R \$ 260.230 .444$ \\
\hline 2010 & $R \$-$ & $\mathrm{R} \$-$ & $R \$ 137.083 .613$ & $\mathrm{R} \$ 137.083 .613$ \\
\hline 2011 & $\mathrm{R} \$ 2.361 .004$ & $\mathrm{R} \$-$ & $R \$ 66.969 .783$ & $R \$ 69.330 .787$ \\
\hline 2012 & $\mathrm{R} \$-$ & $\mathrm{R} \$-$ & $R \$ 70.975 .587$ & $R \$ 70.975 .587$ \\
\hline 2013 & $R \$ 91.561 .008$ & $\mathrm{R} \$-$ & $R \$ 35.841 .200$ & $\mathrm{R} \$ 127.402 .209$ \\
\hline 2014 & $R \$ 276.177 .424$ & $R \$ 3.540 .250$ & $\mathrm{R} \$ 23.827 .262$ & $\mathrm{R} \$ 303.544 .936$ \\
\hline 2015 & $\mathrm{R} \$ 182.283 .111$ & $R \$-$ & $R \$ 27.849 .042$ & $R \$ 210.132 .153$ \\
\hline 2016 & $R \$ 46.556 .622$ & $\mathrm{R} \$ 14.489$ & $R \$ 7.564 .803$ & $\mathrm{R} \$ 54.135 .914$ \\
\hline
\end{tabular}

Quadro 3.3.3: Receita realizada de Convênios e Transferências Federais destinadas ao financiamento do desenvolvimento urbano de município de São Paulo. Ano referência 2016. Fonte: Prefeitura do Município de São Paulo. Elaboração nossa.

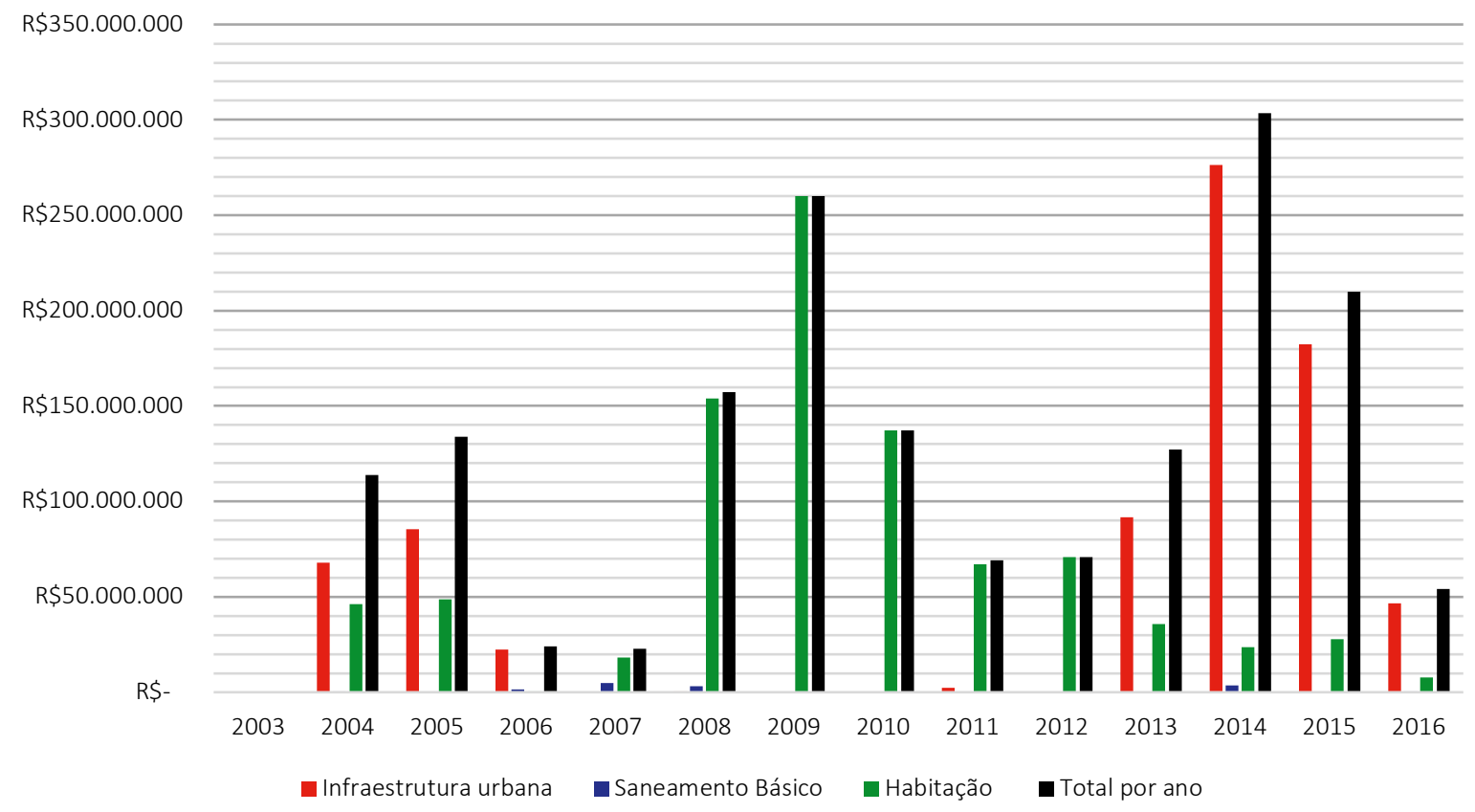

Gráfico 3.3.3: Receita realizada de Convênios e Transferências Federais destinadas ao financiamento do desenvolvimento urbano de município de São Paulo. Ano referência 2016. Fonte: Prefeitura do Município de São Paulo. Elaboração nossa. 
As transferências fiscais federais efetuadas entre 2004 e 2006 se referem principalmente ao programa de reestruturação urbana - sistema viário ( $R$ \$136 milhões captados entre 2004 e 2006), com destaque ao financiamento das obras do sistema viário JacuPêssego (R\$95 milhões dos R\$136 milhões, entre 2004 e 2005)..$^{394}$ Destacam-se ainda os recursos federais destinados às obras da Radial Leste (R\$22 milhões em 2004) e do Terminal de Cargas Fernão Dias (R\$17 milhões em 2006). ${ }^{395}$ Os órgãos federais responsáveis por essa articulação foram o Ministério das Cidades e o Ministério dos Transportes. No que diz respeito à captação de recursos federais destinados às políticas habitacionais, também presentes durante o período de 2004 a 2006, destacam-se os contratos estabelecidos no âmbito do Programa Morar Melhor (R\$47,5 milhões, 2004 e 2005) ${ }^{396}$ e Programa Bairro Legal (R\$47,2 milhões, 2005) $)^{397} .398$

O período de 2007 a 2012 reflete a implementação do Programa de Aceleração do Crescimento (PAC) em 2007 pelo governo federal. O PAC operacionaliza 96\% dos repasses federais à capital paulista entre 2007 e 2012, e o financiamento da habitação assume protagonismo neste período. O PAC Heliópolis, ${ }^{399}$ com repasses realizados no período de 2008 a 2015, condensa mais de R\$716 milhões oriundos da esfera federal, cerca de $42 \%$ do montante total repassado pela União ao município de São Paulo entre 2003 e 2016. Em 2009 é inaugurada a segunda fase do PAC, no entanto, seus desdobramentos em esfera local são menos imediatos e menos expressivos. Apenas em 2012 a receita realizada municipal indica repasses relacionados a contratações no âmbito desse programa, direcionados ao financiamento de obras na favela de Paraisópolis, São Francisco e outras obras de regularização e intervenção em

394 2.4.2.1.99.02 - PROGRAMA DE REESTRUTURAÇÃO URBANA - SISTEMA VIÁRIO JACU-PÊSSEGO/MINIST; 2.4.2.1.99.13 - PROGRAMA DE REESTRUTURAÇÃO URBANA - SISTEMA VIÁRIO - MINISTÉRIO DAS CI.

395 2.4.2.1.99.05 - RADIAL LESTE; 2.4.7.1.05.03 - TERMINAL DE CARGAS FERNÃO DIAS/MT-DNIT/SP-MG.

396 2.4.2.1.99.08 - PROGRAMA MORAR MELHOR - CONTRATO N 157896-38/2003 - MINISTÉRIO DAS Cl; 2.4.2.1.99.12 - PROGRAMA MORAR MELHOR.

397 2.4.2.1.99.15 - PROGRAMA BAIRRO LEGAL.

398 O Tribunal de Contas da União (TCU) realizou uma avaliação sobre o Programa Morar Melhor do Governo Federal, publicada em 2004. Segundo este documento, o objetivo do programa foi contribuir para as condições de habitabilidade das famílias de baixa renda (renda mensal de até três salários mínimos), com preferência ao atendimento de populações em áreas de risco, insalubridade ou degradação ambiental. A avaliação se encontra disponível no portal eletrônico do Tribunal de Contas da União, consultado em 2018.

399 2.4.2.1.99.20 - SEHAB-CT CEF/MIN.CID/PAC (HELIOPOLIS/PQ.FERNANDA/CID A. 
assentamentos precários, três rubricas que representam quase $\mathrm{R} \$ 60$ milhões entre os anos de 2012 e 2016. ${ }^{400}$ Os recursos operacionalizados no âmbito do PAC e PACII representam 46\% das transferências fiscais efetuadas pela União à capital paulista entre 2003 e 2016.

De maneira complementar e paralela ao PACII, entre 2014 e 2016 a SEHAB-PMSP e a Companhia Metropolitana de Habitação de São Paulo (COHAB), administração indireta municipal, assinam convênios com a União, o que significa a captação de outros R\$8,2 milhões em prol do financiamento de políticas habitacionais. ${ }^{401}$

Entre 2013 e 2016 verifica-se incremento de repasses federais destinados a projetos de infraestrutura urbana na cidade de São Paulo, máximo de R\$276 milhões em 2014. Este movimento é, em grande medida, explicado pelo convênio entre a Secretaria Municipal de Infraestrutura Urbana e Obras (SIURB-PMSP) e o Ministério das Cidades, cooperação que significa a captação de mais de $\mathrm{R} \$ 549$ milhões entre 2012 e 2015. Este convênio representa $32 \%$ de todos os recursos federais repassados ao município durante o período de 2003 a 2016. ${ }^{402}$ Mais 6 convênios foram executados entre 2014 e 2016, responsáveis por captar outros R\$50,4 milhões junto ao Governo Federal, em geral destinados ao financiamento da infraestrutura urbana paulistana. ${ }^{403}$

De modo geral, destaca-se a maneira pouco consolidada com que se dá a participação do governo federal ou governo do estado no financiamento do desenvolvimento urbano no município de São Paulo, por meio de uma cooperação interfederativa pontual que parece não fazer parte de um planejamento continuado e articulado entre as esferas local e nacional. ${ }^{404}$

\footnotetext{
400 2.4.2.1.99.28 - SEHAB X MINISTÉRIO DAS CIDADES/ PAC 2 - PARAÍSOPOLIS; 2.4.2.1.99.29 - SEHAB X MINISTÉRIO DAS CIDADES/PAC 2 - SÃO FRANCISCO; 2.4.2.1.99.30 - SEHAB X MIN. CID./PAC 2 - OBRAS REG E INT ASS PREC.

401 1.7.6.1.99.33 - CONVÊNIO COHAB X UNIÃO; 1.7.6.1.99.74 - CONVÊNIO COHAB X UNIÃO; 2.4.7.1.99.34 CONVÊNIO SEHAB X UNIÃO; 2.4.7.1.99.77 - CONVÊNIO SEHAB X UNIÃO.

402 2.4.2.1.99.25 - SIURB X MINISTÉRIO DAS CIDADES.

403 1.7.6.1.99.32 - CONVÊNIO SMPED X UNIÃO; 1.7.6.1.99.77 - CONVÊNIO SMDU X UNIÃO; 2.4.7.1.03.51 CONVÊNIO SIURB X UNIÃO; 1.7.6.1.99.31 - CONVÊNIO AMLURB X UNIÃO; 1.7.6.1.99.72 - CONVÊNIO AMLURB X UNIÃO; 2.4.7.1.99.39 - CONVÊNIO AMLURB X UNIÃO.

404 O Quadro Anexo 6 e o Quadro Anexo 7 explicitam, com bastante clareza, a descontinuidade ou pontualidade associada à cooperação interfederativa em prol do desenvolvimento urbano de município de São Paulo.
} 
Mesmo que o total geral das transferências e convênios interfederativos representem 39\% da composição da receita realizada do município de São Paulo para o período de 2003 a 2016, apenas uma parcela menor dessas transferências e convênios interfederativos, 2,5\%, é destinada ao financiamento do desenvolvimento urbano paulistano (Quadro 3.3.4, Gráfico 3.3.4), o que denota as dificuldades na garantia de recursos orçamentários em prol do financiamento do desenvolvimento urbano, a baixa institucionalização da cooperação interfederativa nesse setor e, em parte, fenômeno também explicado pela histórica vinculação das políticas urbanas e habitacionais aos recursos parafiscais, a exemplo do FGTS.

\begin{tabular}{|c|c|c|c|c|c|}
\hline & $\begin{array}{l}\text { Receita Realizada } \\
\text { Município de São Paulo - } \\
\text { Exceto Convênios e } \\
\text { Transferências } \\
\text { Interdeferativas (A) }\end{array}$ & $\begin{array}{l}\text { Convênios e } \\
\text { Transferências } \\
\text { Interfederativas - } \\
\text { Exceto destinados ao } \\
\text { desenvolvimento } \\
\text { urbano (B) }\end{array}$ & $\begin{array}{l}\text { Convênios e Transferências } \\
\text { Interfederativas destinadas } \\
\text { ao financiamento do } \\
\text { desenvolvimento urbano } \\
\text { de município de São Paulo } \\
\text { (C) }\end{array}$ & $\begin{array}{l}(B+C) / \\
(A+B+C)\end{array}$ & $\begin{array}{l}\text { (C) / } \\
(B+C)\end{array}$ \\
\hline 2003 & $\mathrm{R} \$ 13.485 .812 .936$ & $R \$ 9.993 .845 .396$ & $R \$ 0$ & $43 \%$ & $0,0 \%$ \\
\hline 2004 & $\mathrm{R} \$ 14.689 .536 .107$ & $\mathrm{R} \$ 11.584 .040 .489$ & $R \$ 113.874 .414$ & $44 \%$ & $1,0 \%$ \\
\hline 2005 & $\mathrm{R} \$ 16.693 .276 .398$ & $\mathrm{R} \$ 11.656 .652 .608$ & $\mathrm{R} \$ 134.001 .073$ & $41 \%$ & $1,1 \%$ \\
\hline 2006 & $\mathrm{R} \$ 1_{18.354 .773 .148}$ & $\mathrm{R} \$ 13.125 .110 .891$ & $\mathrm{R} \$ 70.340 .795$ & $42 \%$ & $0,5 \%$ \\
\hline 2007 & $\mathrm{R} \$ 19.399 .454 .542$ & $\mathrm{R} \$ 13.987 .795 .264$ & $\mathrm{R} \$ 219.491 .371$ & $42 \%$ & $1,5 \%$ \\
\hline 2008 & $\mathrm{R} \$ 24.004 .221 .094$ & $\mathrm{R} \$ 15.540 .648 .489$ & $R \$ 306.351 .902$ & $40 \%$ & $1,9 \%$ \\
\hline 2009 & $R \$ 23.040 .002 .000$ & $\mathrm{R} \$ 16.184 .128 .739$ & $\mathrm{R} \$ 538.773 .099$ & $42 \%$ & $3,2 \%$ \\
\hline 2010 & $\mathrm{R} \$ 27.722 .666 .891$ & $\mathrm{R} \$ 17.030 .403 .938$ & $R \$ 326.387 .885$ & $39 \%$ & $1,9 \%$ \\
\hline 2011 & $\mathrm{R} \$ 27.498 .401 .525$ & $\mathrm{R} \$ 17.207 .076 .556$ & $R \$ 593.588 .970$ & $39 \%$ & $3,3 \%$ \\
\hline 2012 & $\mathrm{R} \$ 32.176 .470 .541$ & $\mathrm{R} \$ 17.141 .619 .856$ & $\mathrm{R} \$ 644.197 .962$ & $36 \%$ & $3,6 \%$ \\
\hline 2013 & $\mathrm{R} \$ 29.594 .446 .444$ & $\mathrm{R} \$ 18.256 .639 .088$ & $\mathrm{R} \$ 611.738 .239$ & $39 \%$ & $3,2 \%$ \\
\hline 2014 & $R \$ 30.734 .265 .567$ & $R \$ 17.743 .821 .998$ & $\mathrm{R} \$ 722.718 .731$ & $38 \%$ & $3,9 \%$ \\
\hline 2015 & $\mathrm{R} \$ 34.648 .977 .349$ & $R \$ 16.273 .236 .792$ & $\mathrm{R} \$ 547.245 .244$ & $33 \%$ & $3,3 \%$ \\
\hline 2016 & $R \$ 31.276 .255 .915$ & $R \$ 15.737 .605 .713$ & $R \$ 513.201 .606$ & $34 \%$ & $3,2 \%$ \\
\hline Total & $\mathrm{R} \$ 343.318 .560 .455$ & $\mathrm{R} \$ 211.462 .625 .817$ & $\mathrm{R} \$ 5.341 .911 .291$ & $39 \%$ & $2,5 \%$ \\
\hline
\end{tabular}

Quadro 3.3.4: Receita realizada do município de São Paulo e Convênios e Transferências Interfederativas destinadas ao financiamento do desenvolvimento urbano (considerados os recursos destinados ao FMSAI como transferências do estado de São Paulo). Ano referência: 2016. Fonte: Prefeitura do Município de São Paulo. Elaboração nossa. 


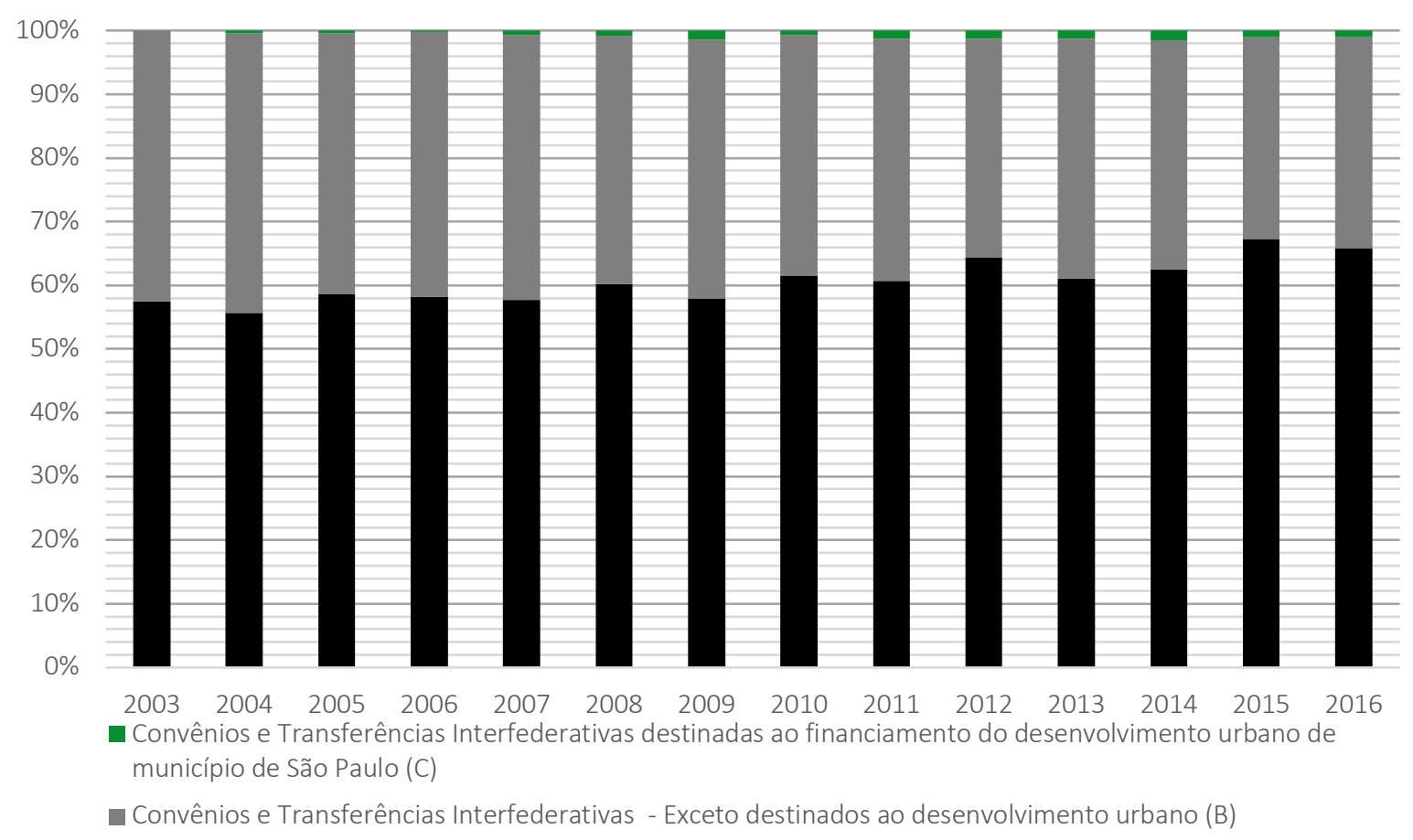

- Receita Realizada Município de São Paulo - Exceto Convênios e Transferências Interdeferativas (A)

Gráfico 3.3.4: Receita realizada do município de São Paulo e Convênios e Transferências Interfederativas destinadas ao financiamento do desenvolvimento urbano (considerados os recursos destinados ao FMSAl como transferências do estado de São Paulo). Ano referência: 2016. Fonte: Prefeitura do Município de São Paulo. Elaboração nossa.

A partir da avaliação sobre as cooperações estadual e federal em prol do financiamento do desenvolvimento urbano a partir da receita realizada do município de São Paulo, evidenciase uma cooperação interfederativa pautada pela construção de convênios e contratos específicos, pontuais, sem aparente preocupação com a continuidade temporal dessa cooperação ou articulação entre esses investimentos.

Quando o assunto é cidade, para além da descontinuidade, a desarticulação horizontal ou vertical entre investimentos estatais tende a significar a diminuição de potencial ou a má gestão dos recursos públicos. Já debatido pelo presente trabalho, a promoção do desenvolvimento urbano se relaciona com a materialidade da provisão da infraestrutura urbana e habitacional nas cidades brasileiras, o que denota a importância de uma atuação estatal contínua e articulada. Não é economicamente racional o asfaltamento desassociado do sistema de saneamento básico, por exemplo. Tampouco é econômica ou socialmente racional a 
urbanização de apenas parcela de assentamento precário, prática que conduz ao acirramento de conflitos urbanos e disputas pelo espaço na cidade também entre os mais pobres, por exemplo. Além disso, assume-se que a promoção das infraestruturas urbana e habitacional de maneira íntegra e articulada é apenas possível a médio prazo.

Já debatido por esta dissertação, a articulação entre esferas nacional, estadual e local significa a ampliação do financiamento fiscal do desenvolvimento urbano, sendo este organizado em torno de convênios e contratos por obras. Contudo, a proposta de cooperação interfederativa orientada pela construção de convênios e contratos pressupõe a disputa por recursos públicos limitados, sendo essa disputa determinada pelas capacidades do beneficiado, onde apenas o ente federado ou órgão estatal com melhores capacidades financeiras e burocráticas será capaz de viabilizar suas propostas, ou viabilizar a expansão do acesso a infraestruturas e serviços urbanos básicos. ${ }^{405}$

Neste sentido, situam-se as competições horizontal e vertical incorporadas e pouco reguladas pelo sistema federativo brasileiro. Mesmo que importantes tratativas entre as esferas local, estadual e federal evidenciem os benefícios da cooperação interfederativa, não é possível verificar esforços direcionados à construção de instituições ou colaborações sólidas e continuadas entre entes, à coordenação interfederativa e à governança multinível, a exemplo do federalismo de cooperação alemão e da recente experiência da assistência social no Brasil. ${ }^{406}$ Assim, especula-se que as premissas qualitativas à cooperação via transferências interfederativas se reduzem a clausulas contratuais, com baixa capacidade avaliativa, reduzidas às obrigatoriedades apresentadas por planos ou leis setoriais, tópico que mereceria maior atenção.

No limite, as avaliações apontam para o entendimento da predação fiscal, uma disputa que é acirrada em conjuntura de crise fiscal e frente às dificuldades em torno da cooperação federativa em prol do desenvolvimento urbano. Associado a isso, é importante reforçar o caráter voluntário das transferências fiscais em prol do desenvolvimento urbano, e o caráter

\footnotetext{
405 Tópico já debatido pelo capítulo 3 da presente dissertação. Ver Kuhn, 2018.

${ }^{406}$ Bachur 2005; Abrucio et al., 2010; Royer, 2013; Bichir, 2016.
} 
discricionário dos gastos em desenvolvimento urbano, elementos que significam fragilidades à garantia de recursos orçamentários, ou não-onerosos. ${ }^{407}$ Desse modo, a atuação estatal como um todo, e a atuação estatal a partir da cooperação entre entes federados em especial, em prol da superação do problema urbano brasileiro demonstra-se dificultosa.

A respeito da associação entre riqueza das jurisdições e acesso a serviços urbanos básicos (Arretche, 2015; p.197) este estudo defende uma relação de causalidade parcial, especialmente sustentada pela descontinuidade no tempo e pela desarticulação verificadas a partir do financiamento fiscal e cooperação interfederativa em prol do desenvolvimento urbano. Quais as possibilidades de universalização do acesso a infraestruturas e serviços urbanos básicos no Brasil em país onde as jurisdições ricas são minoria? E mesmo as jurisdições ricas enfrentam situação de escassez de recursos financeiros permanente (Schick, 1976; Peres, 2018), com dificuldades em financiar o desenvolvimento urbano.

Por fim, a dissolução do problema urbano acontece quando o acesso às infraestruturas e serviços urbanos é encarado a partir da perspectiva do direito a ser universalizado, e quando, por meio disso, determinado indivíduo alcança seu sustento ou qualidade de vida com menor dependência do mercado. ${ }^{408}$ No entanto, o debate sobre o problema urbano parece se deparar com limites, também se partimos das avaliações aqui apresentadas. Isso pois questionamos a premissa de que os gastos sociais em prol do desenvolvimento urbano inevitavelmente significam a superação das precariedades urbanísticas e habitacionais e a redução das desigualdades socioterritoriais. Para além da existência do gasto social, é importante entender como se dá determinado gasto. Neste sentido, a fronteira do conhecimento também diz respeito ao nosso método de pesquisa.

\footnotetext{
${ }^{407}$ Em certa medida, a perspectiva construída a partir do financiamento fiscal do desenvolvimento urbano destoa de avaliação acerca do Fundo de Participação dos Municípios, mecanismo constitucional e regulado de cooperação via transferência interfederativa de recursos públicos desvinculados, de trajetória marcada por crescente dependência municipal, mas com impactos positivos sobre a redução da desigualdade horizontal e a promoção de desenvolvimento local (Deda; Kauchakje, 2017).

${ }^{408}$ Cf. Esping-Andersen, 1985.
} 


\section{Conclusão}

A presente dissertação busca avançar empiria-teoricamente, quanti-qualitativamente, sobre a relação entre urbano e atuação estatal a partir das finanças públicas, relação entendida a partir do financiamento fiscal do desenvolvimento urbano. Qual financiamento fiscal do desenvolvimento urbano é possível no Brasil? é o problema da pesquisa. As possíveis argumentações se desenvolvem em três direções. Possível no sentido de reconhecer a relevância das finanças públicas para a produção do urbano. Possível no sentido de indagar a superação do problema urbano. Possível no sentido de apontar a constrição das finanças públicas, esta associada à nossa inserção internacional e ao regime fiscal brasileiro.

O presente trabalho propõe aproximação teórica a partir do problema de pesquisa, em termos de definições, categorias e articulações entre literaturas. A categoria desenvolvimento urbano, os eixos do desenvolvimento urbano, e a articulação entre teoria da regulação, pensamento social e história econômicas são evidências disso. Propõe aproximação metodológica ao estudo das finanças públicas a partir do campo do planejamento urbano e regional, em termos de avaliação, processamento e tratamento de dados primários orçamentários, a exemplo da estrutura aplicada ao estudo exploratório e ao estudo de caso único. Busca-se demonstrar que essas aproximações permitem o debate sobre a relação entre urbano e atuação estatal.

A atuação estatal auxilia a compreensão sobre o urbano. Recursos no montante de 204 bilhões de reais oriundos do Orçamento Geral da União foram liquidados em prol do desenvolvimento urbano entre 2000 e 2016. A esfera federal financiou a urbanização de assentamentos precários, construção de casas, ampliação e qualificação do acesso aos serviços urbanos de água, esgoto, drenagem urbana, de gestão dos resíduos sólidos, energia elétrica, mobilidade urbana, qualificação da gestão de terras públicas e do patrimônio histórico, e gestão e planejamento estatais, por exemplo. O Programa de Aceleração do Crescimento (PAC) Urbanização de Assentamentos Precários e os subsídios à Faixa 1 do Programa Minha Casa, Minha Vida são exemplos e produtos dessa atuação estatal. 
O urbano auxilia a compreensão sobre a atuação estatal. A avaliação sobre o financiamento fiscal aponta distinções entre os eixos do desenvolvimento urbano, seja em temos de montantes liquidados, seja em termos de estratégias da liquidação dos recursos financeiros. A operacionalização dos recursos financeiros a partir do sistema bancário, as capacidades administrativas e financeiras dos governos subnacionais, em associação aos setores produtivos e qualidade das obras e serviços financiados são pertinentes à compreensão da atuação estatal. Os agentes e a produção do espaço contribuem à compreensão sobre a execução dos recursos fiscais federais. Cabe lembrar, importante liquidação de recursos esteve associada à centralidade da agência privada, seja por meio de uma atuação garantidora do mercado de energia elétrica e da atuação das concessionárias de serviços urbanos, seja por meio do acesso subsidiado a unidades habitacionais produzidas via mercado.

Sobre o financiamento fiscal do desenvolvimento urbano, cabe destacar que o início do século XXI é permeado por um ceticismo a respeito da atuação estatal, ceticismo que também se faz presente na regulação e controle dos recursos orçamentários federais. Após a crise cambial na virada do século, e mesmo diante de um desempenho macroeconômico já positivo, a mobilização das finanças públicas como condição a uma atuação estatal em torno de um desenvolvimento urbano não aparece planteada, apesar de ainda fazer-se necessária, como diante da crise da energia elétrica de 2001.

Frente à desaceleração econômica, ao aumento da taxa de juros, a proposta de um novo ajuste fiscal federal perde forças em 2005. É entre 2005 e 2006, assim, que o Estado nacional resgata alguns mecanismos de intervenção na economia, e é indicado o redirecionamento da política fiscal federal. A partir de 2005, mas especialmente entre 2007 e 2014, há relevante incremento dos valores não onerosos federais, recursos orçamentários, empenhados ou reservados em prol do financiamento fiscal do desenvolvimento urbano. Em 2007 se identifica a proposta de desenvolvimento de longo prazo e aceleração do crescimento econômico com inclusão social a partir do planejamento estatal, orçamento e investimentos públicos.

A execução desses recursos se demonstrou dificultosa ao longo do tempo, também em associação com o agente executor desses recursos, se agência financeira e setor produtivo da 
construção civil, se estados e municípios, por exemplo. De qualquer modo, há uma retomada, que também é histórica, sobre um entendimento sobre a relevância da esfera federal para a articulação de projetos e investimentos urbanos e habitacionais no país, e mesmo a partir do orçamento público, o qual não prevê ou assegura recursos para as políticas urbanas e habitacionais, a partir do qual se entende uma atuação discricionária, não obrigatória. A retomada da relevância da esfera federal também se relaciona com a construção de institucionalidades na esfera federal, como é o caso do extinto Ministério das Cidades.

A crise de 2008 afeta o crescimento econômico brasileiro em 2009, mas não os investimentos públicos federais, ou o financiamento do desenvolvimento urbano, e este cresce entre 2008 e 2010. Em 2011 verificam-se importantes ajustes dos investimentos federais, comportamento geral que não encontra correspondência no financiamento fiscal do desenvolvimento urbano. Entre 2013 e 2015 defende-se que a retomada do crescimento se dê a partir dos investimentos em infraestrutura. Contudo, as dificuldades associadas à garantia de recursos orçamentários para a realização de investimentos e financiamento do desenvolvimento urbano já aparece acirrada frente ao rebaixamento de rating brasileiro para grau especulativo a partir da avaliação de risco-país, fato associado à alteração da situação fiscal nacional.

Em parte devido à regulação do orçamento público, à não segurança de aportes de recursos orçamentários ao desenvolvimento urbano, não se verifica forte correlação entre bom desempenho macroeconômico e ampliação do financiamento fiscal do desenvolvimento urbano. Se entre 2004 e 2010 nossa economia cresceu, não podemos dizer o mesmo, nas mesmas proporções, sobre os recursos orçamentários destinados ao desenvolvimento urbano. O inverso ocorre entre 2011 e 2014. Apostar em um crescimento econômico enquanto resolução ao financiamento fiscal de políticas públicas não parece ser suficiente à atuação estatal frente ao problema urbano.

A criação do Ministério das Cidades e institucionalidades da política urbana e habitacional não está associada a uma forte ampliação dos recursos financeiros destinados ao desenvolvimento urbano. Contudo, há correlação entre construção de institucionalidades 
federais e a modalidade de aplicação dos recursos fiscais, dado que entre 2003 e 2008 se verifica importante esforço de descentralização da execução dos recursos oriundos do Orçamento Geral da União, em especial por meio de transferências fiscais a municípios. No ano de 2008, em acordo com valores empenhados e a modalidade de aplicação desses recursos, cerca de $50 \%$ dos recursos orçamentários federais alocados em desenvolvimento urbano são classificados como transferências a municípios. Denota-se a importância da esfera federal para a formulação, regulação, financiamento das políticas públicas no país, o que induz a construção de capacidades subnacionais, orientada pela captação de recursos e a execução descentralizada das políticas públicas federais.

Mesmo que a reserva ou execução dos recursos orçamentários em prol do desenvolvimento urbano seja dificultosa, oscile, seja incerta, não é pertinente desconsiderar o sistema a qual os recursos não onerosos estão associados, a organização socioterritorial do poder no país, o sistema federativo tripartite. Ao menos 3.267 municípios brasileiros foram beneficiados pela liquidação dos recursos oriundos do Orçamento Geral da União. É possível imaginarmos um número ainda maior. Isso denota a alta capilaridade territorial dos recursos fiscais federais. Os recursos orçamentários podem subsidiar a associação e coordenação entre governos federal, estadual e municipal. É também evidência da solidariedade presente na organização territorial do poder brasileira, a partir da qual, após a concentração da riqueza pública por esfera federal, os recursos são redistribuídos com vistas à dissolução de precariedades, desigualdades e universalização do acesso a direitos.

Destaca-se, contudo, a maneira pouco consolidada com que se dá a cooperação interfederativa em prol do financiamento fiscal do desenvolvimento urbano, que parece não fazer parte de um planejamento continuado e articulado entre as esferas local e nacional. Tratase de um financiamento organizado por meio de convênios e contratos de obras, o que tende a uma descontinuidade temporal de intervenções sobre os diferentes territórios e à reprodução de desigualdades socioterritoriais, já bastante expressivas.

Ainda que se verifiquem as reformas orçamentárias, não é manifesta a territorialização da execução orçamentária, o que denota a opacidade da alocação de recursos fiscais em termos 
territoriais. Dotar a execução do gasto público de categorias territoriais, que efetivamente permitam a territorialização do financiamento do urbano, contribuiria para avanços, seja em termos de políticas públicas, seja em termos do entendimento sobre a relação entre atuação estatal e urbano a partir das finanças públicas. Dotar a administração de processos e procedimentos, organizados em um sistema, seria necessário. A territorialização do gasto público possibilitaria estudos sobre tendências e comportamentos relativos à distribuição espacial desses recursos financeiros, a avaliação e planejamento de atuação estatal. O estudo também debate a premissa de que os gastos sociais em prol do desenvolvimento urbano inevitavelmente significam a superação das precariedades urbanísticas e habitacionais e a redução das desigualdades socioterritoriais. Evidenciam-se possíveis aplicações das contribuições aqui desenvolvidas, mas também possibilidades a novas pesquisas.

Em suma, a atual capacidade de intervenção estatal é diminuta, não cabendo comparações com o período do desenvolvimento industrial do país, consolidação do mercado nacional e construção de instituições públicas. Após a "década perdida" de 1980, o engendramento da América Latina na crise da dívida externa, a reforma gerencial da década de 1990, a construção de um novo regime fiscal apresenta outro ritmo e parâmetros às contas públicas, face de uma nova inserção internacional da economia nacional em desindustrialização. A Lei de Responsabilidade Fiscal ilustra o regramento sobre o orçamento público, responsivo, garantidor de uma segurança intertemporal, per se meritoso de um debate. Contudo, mesmo que sempre oscilante, o início do século XXI confere matizes a esse movimento histórico, social, econômico iniciado nos finais da década de 1970.

O Estado, mesmo considerado o momento histórico, o regime de acumulação flexível, é uma estrutura associada à produção do urbano brasileiro, com implicações econômicas mas também sociais. Concentra e redistribui a riqueza pública, articula projetos e investimentos, assegura e amplia mercados, amplia o acesso aos serviços urbanos e, como tal, vincula-se umbilicalmente ao urbano, apenas para citar comportamentos associados ao orçamento público. Materializa-se tanto pela redistribuição da riqueza pública pelo território nacional e interiorização de investimentos, em especial por meio da indução e associação aos governos subnacionais. Essa atuação é dotada de materialidade, significa a provisão de infraestruturas 
urbana e habitacional, e por isso pertinente ao campo do planejamento urbano e regional. Como tal, também se relaciona com o trabalho, a técnica e a terra no país, dada a economia política da urbanização. Evidentemente, não se trata aqui de negar as dimensões e particularidades contemporâneas necessárias ao entendimento dos fenômenos econômicos e sociais, dentre estes o urbano e as finanças, tampouco afirmar que o Estado condensa todas as respostas. Apenas não há de perder de vista que as formas novas parecem conviver com formas antigas, e os processos históricos podem não ser disruptivos, mas sim dotados de matizes, também a depender da resolução dos conflitos em nossa sociedade.

Neste sentido, a presente avaliação ilumina a tensão entre o Estado articulador de investimentos e projetos, condutor de processos econômicos e sociais, em relação ao Estado garantidor da agência privada nacional e internacional, regulador, organizado em torno da concessão da provisão de infraestruturas e serviços. Essa tensão está sempre presente, mas é evidenciada frente à desaceleração econômica nacional e ausência de uma ampla reforma tributária, de tal modo que a garantia de continuidade do financiamento fiscal do desenvolvimento urbano no país é diminuta, em especial se considerada a implementação da austeridade fiscal permanente em 2016. 


\section{Bibliografia}

ABRUCIO, Fernando Luiz; SANO, Hironobu; SYDOW, Cristina Toth. Radiografia do associativismo territorial brasileiro: tendências, desafios e impactos sobre as regiões metropolitanas. In: KLINK, Jeroen. (Org.). Governança das Metrópoles Conceitos, Experiências e Perspectivas. São Paulo: Annablume, 2010, p. 21-48.

ACEMOGLU, Daron; ROBINSON, James A. The Rise and Decline of General Laws of Capitalism. In: Journal of Economic Perspectives, Volume 29, Number 1, pp. 3-28. 2015.

AFONSO, José Roberto. Cenário Fiscal Atual no Brasil: implicações para governos subnacionais. Apresentação realizada no Banco Interamericano de Desarrollo, Washington DC, 10/10/2017. Disponível em <http://www.joserobertoafonso.com.br/governos-subnacionais-afonso/>, consultado em abril de 2018.

ALMEIDA, Ronaldo de. Estudo de caso: foco temático e diversidade metodológica. In: ABDAL, Alexandre; OLIVEIRA, Maria Carolina Vasconcelos; GHEZZI, Daniela Ribas; SANTOS JR., Jaima. (Org.). Métodos de pesquisa em Ciências Sociais: Bloco Qualitativo. 1ed.: Sesc São Paulo/Cebrap, 2016.

ALONSO, Angela Maria. Flores, votos e balas: o movimento abolicionista brasileiro (1868-1888). 1. ed. São Paulo: Companhia das Letras, 2015.

ANDRADE, Thompson Almeida; SERRA, R. V. . O Desempenho das Cidades Médias no Crescimento Populacional Brasileiro no Período 1970/2000. In: Thompson Almeida Andrade; Rodrigo Valente Serra. (Org.). As Cidades Médias Brasileiras. 1aed. Rio de Janeiro: IPEA, 2001, v. 1, p. 129-170.

ARANTES, Pedro Fiori. O ajuste urbano: as políticas do Banco Mundial e do BID para as cidades. In: Revista Pós, n. 20, 2006.

ARANTES, Pedro Fiori. Em busca do urbano: marxistas e a cidade de São Paulo nos anos de 1970. Novos Estudos CEBRAP (Impresso), p. 103-127, 2009.

ARANTES, Rogério B.; COUTO, Cláudio G. . 1988:2018: Trinta anos de constitucionalização permanente. In: Naércio Menezes Filho; Andre Portela Sousa. (Org.). A Carta. Para entender a Constituição brasileira. 1ed.São Paulo: Todavia, 2019, v. 1, p. 13-52.

ARRETCHE, Marta. Desarticulação do BNH e autonomização da política habitacional. In: AFFONSO, Rui de Britto A.; SILVA, Pedro Luiz B. (Orgs.). Descentralização e Políticas Sociais. São Paulo: FUNDAP, 1996.

ARRETCHE, Marta. Política Habitacional entre 1986 e 1994. In: ARRETCHE, Marta; RODRIGUEZ, Vicente (Orgs.). Descentralização das Políticas Sociais no Estado de São Paulo. São Paulo: FUNDAP/ FAPESP; Brasília: IPEA, 1998

ARRETCHE, Marta. Democracia, federalismo e centralização no Brasil. Rio de Janeiro, Editora FGV/Editora Fiocruz, 2012.

ARRETCHE, Marta. Trajetórias das Desigualdades: como o Brasil mudou nos últimos 50 anos. 1. ed. São Paulo: UNESP, 2015.

ARRETCHE, Marta. Democracia e Redução da Desigualdade Econômica no Brasil: a inclusão dos outsiders. In: Revista Brasileira de Ciências Sociais, v. 33, pp. 1-23, 2018. 
ARRETCHE, Marta. Transferências fiscais no Brasil. In: Menezes Filho, Naercio e Souza, André Portela. (Org.). A Carta. Para entender a Constituição Brasileira. 1ed.São Paulo: Todavia, 2019, v. 1, p. 53-81.

ATKINSON, A. B.; BRANDOLINI, A. Unveiling the Ethics behind Inequality Measurement: Dalton's Contribution to Economics. Econ J, 125: 209-234. 2015.

BACHUR, João Paulo. Federalismo fiscal, atribuições fiscais constitucionais e equalização regional: EUA, Alemanha e Brasil em perspectiva comparada. In: Revista do Serviço Público, Brasília 56 (4):377-401, 2005.

BALL, Michael. The development of capitalism in housing provision. International Journal of Urban and Regional Research, v. 5, n. 2, p. 145-177, 1981.

BARAT, Josef. O financiamento do desenvolvimento urbano no Brasil - O caso da área metropolitana de São Paulo. In: Revista de Administração Pública v. 18, n. 2, 1984.

BARAVELLI, José Eduardo. Trabalho e tecnologia no programa MCMV. Tese de doutoramento apresentada à Universidade de São Paulo, 2014.

BARROS, R. P. de; HENRIQUES, R; MENDONÇA, R. Desigualdade e Pobreza no Brasil: retrato de uma estabilidade inaceitável. In: Revista Brasileira de Ciências Sociais, 15(42), pp.123-42, 2010.

BASTOS, P. P. Z. . Que horas ela volta? Economia política e política econômica de Lula a Dilma.. In: Maringoni, G.; Medeiros, J.. (Org.). Cinco mil dias: O Brasil na era do Lulismo.. 1ed.São Paulo: BOITEMPO, 2017, v. , p. 77-89

BERTUSSI, Geovana Lorena; ELLERY JR., Roberto. Gastos públicos com infraestrutura de transporte e crescimento econômico: uma análise para os estados brasileiros. In: In: Boletim regional, urbano e ambiental / Instituto de Pesquisa Econômica Aplicada. Diretoria de Estudos e Políticas Regionais, Urbanas e Ambientais. Brasília : Ipea. Dirur, 2011.

BICHIR, Renata. Novas agendas, novos desafios: reflexões sobre as relações entre transferência de renda e assistência social no Brasil. In: Novos Estudos Cebrap, mar. 2016, n. 104, p. 111-136.

BOLAFFI, Gabriel. Habitação e Urbanismo: o problema e o falso problema. In: Ensaios de Opinião. vol. 2/1, pp. 73-83, 1975.

BONDUKI, Nabil. A política Nacional de Habitação do século XXI (2003-2010). In: BONDUKI, Nabil. Pioneiros da Habitação Social no Brasil 1: Cem anos de política pública no Brasil . São Paulo: Edições SESC/Editora da UNESP, 2014.

BOYER, Robert. Teoria da Regulação: os fundamentos. Editora Estação Liberdade, São Paulo, 2009.

BOYER, Robert. The Four Fallacies of Contemporary Austerity Policies: The Lost Keynesian Legacy. In: Cambridge Journal of Economics 36(1), 2012, pp. 283-312.

BRADLEY, David; HUBER, Evelyne; MOLLER, Staphanie; NIELSEN, François; STEPHENS, John D. Distribution and Redistribution in Post-industrial Societies. In: World Politics, 55, pp. 193-228, 2003.

BRASIL, 2009. Plano Nacional de Habitação - PlanHab.

BRASIL. Ministério do Planejamento, Orçamento e Gestão. Secretaria de Manual técnico de orçamento MTO. Versão 2012. Brasília, 2011.

BRASIL, 2013. Plano Nacional de Saneamento básico - PlanSab. 
BRASIL. Ministério do Planejamento, Orçamento e Gestão. Secretaria de Manual técnico de orçamento MTO. Versão 2016. Brasília, 2015.

BRENCK, Clara; CARVALHO, Laura. Limites para o crescimento com mudança estrutural no Brasil no século XXI. In: M. V. Chiliatto Leite. (Org.). Alternativas para o desenvolvimento brasileiro: novos horizontes para a mudança estrutural com igualdade. 1ed.Santiago: Comissão Econômica para a América Latina e o Caribe (CEPAL), 2019.

CAMARGO, C. P. F. de; CARDOSO, F. H.; MAZZUCCHELLI, F.; MOISÉS, J. Á; KOWARICK, L; ALMEIDA, M. H. T.; SINGER, P. I; BRANT, V. C. São Paulo 1975: Crescimento e pobreza. Edições Loyola, 1975.

CAMPOS, Pedro Henrique Pedreira. Empresariado e ditadura no Brasil: o estado atual da questão e o caso dos empreiteiros de obras públicas. In: Revista Transversos, p. 335-358, 2018.

CANO, W. Raízes da concentração industrial em São Paulo. São Paulo: T. A. Queiroz, 1981.

CANO, W. Ensaios sobre a crise urbana do Brasil. Campinas : Editora da Unicamp, 2011.

CARDOSO, Adauto Lúcio; ARAGÃO, Thêmis Amorim. Do fim do BNH ao Programa Minha Casa Minha Vida: 25 anos da política habitacional no Brasil. In: CARDOSO, Adauto Lúcio (Org.). O Programa Minha Casa Minha Vida e seus efeitos territoriais. Rio de Janeiro: Letra Capital, 2013.

CARDOSO, Adauto Lúcio; JAENISCH, Samuel Thomas; ARAGÃO, Thêmis Amorim. 22 anos de política habitacional no Brasil: da euforia à crise. Rio de Janeiro: Letra Capital: Observatório das Metrópoles, 2017. 367 p.

CARDOSO, Adauto Lúcio; DENALDI, Rosana (Org.). Urbanização de favelas no Brasil: um balanço preliminar do PAC. 1. Ed. Rio de Janeiro: Letra Capital, 2018.

CARNEIRO, R. A economia política do ensaio desenvolvimentista. In: Estudos Avançados, 2017, vol.31, n.89, pp.61-66.

CARVALHO, Carlos Henrique Ribeiro de; PEREIRA, Rafael Henrique Moraes. Efeitos da variação da tarifa e da renda da população sobre a demanda de transporte público coletivo urbano no Brasil. In: Boletim regional, urbano e ambiental / Instituto de Pesquisa Econômica Aplicada. Diretoria de Estudos e Políticas Regionais, Urbanas e Ambientais. Brasília : Ipea. Dirur, 2009.

CARVALHO, Laura. Valsa brasileira: do boom ao caos econômico. Ed. São Paulo: Todavia, 2018.

CENTRO DE ESTUDOS DA METRÓPOLE (CEM)/CEBRAP; SECRETARIA NACIONAL DE HABITAÇÃO/MINISTÉRIO DAS CIDADES. Capacidades Administrativas dos Municípios Brasileiros para a Política Habitacional, 2012.

COMARÚ, Francisco de Assis. Políticas de habitação e desenvolvimento urbano em Municípios Saudáveis: o caso de Bertioga - SP. Tese de doutorado em saúde pública apresentada à Universidade de São Paulo, 2004.

CONGRESSO NACIONAL. Parecer de Comissão Mista de Planos, Orçamentos Públicos e Fiscalização "Da Comissão Mista de Planos, Orçamentos Públicos e Fiscalização - CMO, sobre o Projeto de Lei no 30, de 2003-CN, que "Dispõe sobre o Plano Plurianual para o período 2004/2007", 2004.

CONGRESSO NACIONAL. Parecer de Comissão Mista de Planos, Orçamentos Públicos e Fiscalização "Da Comissão Mista de Planos, Orçamentos Públicos e Fiscalização - CMO, sobre o Projeto de Lei no 31/2007 que dispõe sobre o Plano Plurianual para o período de 2008 a 2011 - PPA 2008- 2011", 2007. 
CONGRESSO NACIONAL. Parecer de Comissão Mista de Planos, Orçamentos Públicos e Fiscalização "Da Comissão Mista de Planos, Orçamentos Públicos e Fiscalização - CMO, sobre o Projeto de Lei no 29/2011 que dispõe sobre o Plano Plurianual para o período de 2012 a 2015 - PPA 2012-2015”, 2011.

CONGRESSO NACIONAL. Parecer de Comissão Mista de Planos, Orçamentos Públicos e Fiscalização "Da Comissão Mista de Planos, Orçamentos Públicos e Fiscalização - CMO, sobre o Projeto de Lei no 06/2015 que dispõe sobre o Plano Plurianual para o período de 2016 a 2019 - PPA 2016-2019”, 2015.

CORE, Fabiano Garcia. Reforma gerencial dos processos de planejamento e orçamento / Fabiano Garcia Core - Brasília: ENAP, 2001.

DAGNINO, E.. Confluência perversa, deslocamentos de sentido, crise discursiva?. In: Alejandro Grimson. (Org.). La cultura em las crisis latinoamericanas. Buenos Aires: CLACSO, 2004.

DARDOT, Pierre; LAVAL, Christian. A nova razão do mundo: ensaio sobre a sociedade neoliberal. São Paulo: Editora Boitempo, 402 p, 2016.

DEÁK, Csaba. Em busca das categorias da produção do espaço. São Paulo : Editora Annablume, 2016.

DE PAULA, Luiz Fernando ; FRITZ, Barbara ; PRATES, Daniela M. . Keynes at the periphery: Currency hierarchy and challenges for economic policy in emerging economies. JOURNAL OF POST KEYNESIAN ECONOMICS, v. 40, p. 183-202, 2017.

DEDA, Carin Caroline; KAUCHAKJE, Samira. Sistema político multinível no Brasil: uma análise da relação entre transferências intergovernamentais e redução das desigualdades territoriais no Estado do Paraná. In: Revista Brasileira De Estudos Urbanos e Regionais, v. 19, p. 530-553, 2017.

DWECK, E.; TEIXEIRA, R. A. . A política fiscal do governo Dilma e a crise econômica. Campinas: Instituto de Economia da UNICAMP, 2017 (Texto para Discussão).

DWECK, E.; ROSSI, P. L. . Políticas sociais, distribuição, crescimento e mudança estrutural. In: M. V. Chiliatto Leite. (Org.). Alternativas para o desenvolvimento brasileiro: novos horizontes para a mudança estrutural com igualdade. 1ed.Santiago: Comissão Econômica para a América Latina e o Caribe (CEPAL), 2019, v. 1, p. 97-116.

ESPING-ANDERSEN, Gøsta. Politics against markets. The Social Democratic Road to Power. Princeton: Princeton University Press, 1985.

ESPING-ANDERSEN, Gøsta. Power and distributional regimes. In: Politics and Society, 14(2): 185-222, 1985.

ESPING-ANDERSEN, Gøsta. As três economias públicas do Welfare State. Lua nova, n. 24, 1991.

FAGNANI, Eduardo. O fim de um ciclo improvável (1988-2016). A política social dos governos petistas e a derrocada da cidadania pós-golpe.. In: Gilberto Maringoni e Juliano Medeiros. (Org.). Cinco mil dias: O Brasil na era do lulismo. 1ed.São Paulo: Boitempo, 2017, v. 1, p. 117-132.

FARIAS, Agnaldo Aricê Caldas. Arquitetura Eclipsada / Notas sobre Arquitetura e História, a Propósito da Obra de Gregori Warchavchik, Introdutor da Arquitetura Moderna no Brasil. Dissertação apresentada à Universidade Estadual de Campinas, 1990.

FAUSTINO, R. B.; PRONI, M. W. . Avanços e limites da política de desenvolvimento urbano no Brasil (20012014).. Planejamento e Politicas Publicas, v. 46, p. 181-215, 2016 
FEVEREIRO, José Luís. Dívida pública, problema ou solução. In: Gilberto Maringoni e Juliano Medeiros. (Org.). 5000 dias: o Brasil na era do lulismo. 1ed.São Paulo: Boitempo, 2017, v. , p. 107-115.

FILOCOMO, G.. A conquista da Eletropaulo pelo capital italiano. E a cidade?. Justificando; Carta Capital, 08 jun. 2018.

FILOCOMO, G.. A Cooperação Interfederativa e o Financiamento do Desenvolvimento Urbano. In: Maria Cristina da Silva Leme; Maria Lucia Refinetti Martins. (Org.). Residência em Arquitetura e Urbanismo na Universidade de São Paulo. 1ed.São Paulo: FAU USP, 2018, v. 1, p. 501-532.

FILOCOMO, G.. A distribuição de renda e o acesso à cidade estão relacionados?. Justificando; Carta Capital, 02 abr. 2019.

FILOCOMO, G.. Crescimento econômico é suficiente ao enfrentamento das necessidades urbanísticas e habitacionais?. Justificando; Carta Capital, 14 mar. 2019.

FILOCOMO, G.. Dimensões fiscais do desenvolvimento urbano brasileiro: reflexões em torno do Orçamento Geral da União. In: XVIII Encontro Nacional da Associação Nacional de Pós-graduação e Pesquisa em Planejamento Urbano e Regional, 2019, Natal. Encontro Nacional da Associação Nacional de Pós-graduação e Pesquisa em Planejamento Urbano e Regional ? ENANPUR: Tempos em / de Transformação ? Utopias (2019 : Natal). Natal: EDUFRN, 2019.

FIORI, José Luis da Costa. Os Moedeiros Falsos. Petrópolis: Editora Vozes, 1998.

FIORI, José Luis da Costa. O voo da coruja: para reler o desenvolvimento brasileiro. Rio de Janeiro: Editora Record, 2004. Prefácio.

FIX, Mariana; PAULANI, Leda. Considerações Teóricas sobre a Terra como Puro Ativo Financeiro e o Processo de Financeirização. Brazilian Journal of Political Economy, v. 39, p. 638-657, 2019.

FUNDAÇÃO FRIEDRICH EBERT; BRASIL DEBATE. Austeridade e Retrocesso: Impactos sociais da política fiscal no Brasil, 2018.

GAMBIAGI, Fabio; ALÉM, Ana Cláudia. Finanças públicas: teoria e prática no Brasil. Rio de Janeiro: Elsevier, 2011.

GARSON, Sol. Planejamento, orçamento e gasto com políticas públicas: uma metodologia de apuração para Estados e Municípios. Porto Alegre, RS: Editora Fi, 2018.

GIVISIEZ, G. H. N.; OLIVEIRA, Elzira Lucia de (Org.) . Demanda futura por moradias: demografia, habitação e mercado. 1. ed. Niteroi, RJ: UFF, Pró-reitoria de Pesquisa, Pós-Graduação e Inovação, 2018.

GOBETTI, Sérgio Wulff; ORAIR, Rodrigo Octávio. Progressividade tributária: a agenda negligenciada. Texto para Discussão (IPEA Brasília), v. 2190, 2016.

GOMIDE, Alexandre A.; PIRES, Roberto R. C. . Arranjos Institucionais de Políticas Críticas para o Desenvolvimento: nota de pesquisa. Boletim de Análise Político-Institucional do Ipea, v. 3, p. 71-76, 2013.

HARVEY, David. O trabalho, o capital e o conflito de classes em torno do ambiente construído nas sociedades capitalistas avançadas. Revista Espaço \& Debates. São Paulo, n. 6, pp. 7-14, 1982 [1976].

INSTITUTO DE PESQUISA ECONÔMICA APLICADA (IPEA). Questão Social e Políticas Sociais no Brasil Contemporâneo. Brasília: IPEA, 2005. v. 1. 435p . 
INSTITUTO DE PESQUISAS ECONÔMICAS APLICADAS (IPEA). Questão social e políticas sociais no Brasil contemporâneo. Brasília, 2009.

INSTITUTO DE PESQUISA ECONÔMICA APLICADA (IPEA). O uso dos instrumentos de financiamento para a política urbana no Brasil. Comunicados do IPEA, № 112. Brasília, 2011.

ISODA, Marcos Kiyoto de Tani e. Transporte Sobre Trilhos na Região Metropolitana de São Paulo: Estudo sobre a concepção e inserção das redes de transporte de alta capacidade. 2013. Dissertação (Mestrado em Arquitetura e Urbanismo) - Universidade de São Paulo.

JARAMILLO, Samuel. Las formas de producción del espacio construido en Bogotá. In: PRADILLA, Emilio (org.). Ensayos sobre el problema de la vivienda en México. México: Latina UNAM, 1982. pp. 149-212.

KLIASS, Paulo. Aspectos da política fiscal. In: Gilberto Maringoni e Juliano Medeiros. (Org.). 5000 dias: o Brasil na era do lulismo. 1ed.São Paulo: Boitempo, 2017, v. , p. 101-106.

KLINK, J. J.; SOUZA, M. B. Financeirização: conceitos, experiências e a relevância para o campo do planejamento urbano brasileiro. In: Cadernos Metrópole, v. 19, pp. 379-406, 2017.

KOWARICK, Lúcio. A espoliação urbana. 2a Edição. Rio de Janeiro : Paz e Terra, 1993 [1979].

KUHN, F. A Política de Saneamento Básico na Federação Brasileira e as Desigualdades Regionais: uma análise dos municípios paulistas. Dissertação de mestrado apresentada à Universidade Federal do ABC, 2018.

LEME, Maria Cristina da Silva. A formação do pensamento urbanístico no Brasil, 1895-1965. In: LEME, Maria Cristina da Silva (coord.). Urbanismo no Brasil 1895-1965. São Paulo : Studio Nobel; FAUUSP; FUPAM, 1999.

LEME, Maria Cristina da Silva. Urbanismo e política no Brasil: continuidades, contradições e rupturas. In: LEME, Maria Cristina da Silva (Org.). Urbanismo e política no Brasil dos anos 1960. São Paulo: Annablume, 2019.

LENCIONI, Sandra. Metrópole, metropolização e regionalização. Rio de Janeiro : Consequência Editora, 2017.

LEVI, Maria Luiza. Sistema de Saúde no Brasil: redistributividade no modelo de financiamento e provisão. Revista Parlamento \& Sociedade, v. 4, p. 33-63, 2016.

LIRA, J. T. C.. Ruptura e construção: Gregori Warchavchik, 1917-1927. Novos Estudos CEBRAP (Impresso), v. 78, p. 145-167, 2007.

LOPES, Maria del Mar Solbas. Relacionamento entre o Legislativo e Entidade de Fiscalização Superior: o caso brasileiro, chileno e argentino. 2008. Monografia curso Aperfeiçoamento/Especialização em Curso de Pós-Graduação em Ciência Política, Universidade do Legislativo Brasileiro.

LOPREATO, Francisco Luiz Cazeiro. Caminhos da política fiscal do Brasil. Editora Unesp, São Paulo, 2013.

MAC DOWELL, Maria Cristina. Financiamento urbano no Brasil: um olhar sobre as finanças municipais. In: PONTES, Eglaísa Micheline; CESARE, Claudia M. de (org.). Financiamento das Cidades: instrumentos fiscais e de política urbana. Brasília/Ministério das Cidades, 2007.

MARICATO, Ermínia. A produção capitalista da casa (e da cidade) no Brasil Industrial. 2. ed. São Paulo, SP: Alfa Omega, 1979. 
MARICATO, Ermínia. The urban reform movement in Brazil. In: International Journal of Urban and Regional Research, London, 1988.

MARICATO, Ermínia. Reforma Urbana: Limites e Possibilidades. Uma Trajetória Incompleta. Ribeiro, L. C de Q.; Santos Jr., O. A. dos (Orgs.). Globalização, Fragmentação e Reforma Urbana. Rio de Janeiro: Civilização Brasileira, 1994, p.309-325.

MARICATO, Ermínia. Metrópole na periferia do capitalismo. 1. ed. São Paulo: Hucitec, 1996.

MARICATO, Ermínia. Política urbana e de habitação social: um assunto pouco importante para o governo FHC. Revista Praga, São Paulo: Hucitec, v. 1, n.6, p. 67-78, 1998.

MARICATO, Ermínia. O Ministério das Cidades e a política nacional de desenvolvimento urbano : Cidades brasileiras: a matriz patrimonialista. Políticas Sociais (IPEA), v. 12, p. 211-220, 2006

MARICATO, Ermínia. Nunca fomos tão participativos. Agência Carta Maior, São Paulo, 26 nov. 2007

MARICATO, Ermínia. Por um novo enfoque teórico na pesquisa sobre habitação. Cadernos Metrópole (PUCSP), v. 21, p. 33-52, 2009.

MARICATO, Ermínia. Nossas cidades estão ficando inviáveis. Entrevista para a Revista Desenvolvimento, por Gilberto Maringoni - outubro, 2011.

MARICATO, Ermínia. Cidades e Luta de Classes no Brasil. In: Maricato, Ermínia. Para entender a crise urbana. 1. ed. São Paulo: Expressão Popular, 2015.

MARICATO, Ermínia; ROYER, Luciana de Oliveira. A política urbana e de habitação. In: Gilberto Maringoni; Juliano Medeiros. (Org.). Cinco mil dias. 1ed. São Paulo: Boitempo, 2017, v. 1, p. 147-157.

MARQUES, Eduardo Cesar Leão. A metrópole de São Paulo no início do século XXI. In: Revista USP, p. 23, 2014.

MARQUES, Eduardo Cesar Leão. Condições urbanas. In: Trajetórias das desigualdades: como o Brasil mudou nos últimos cinquenta anos. São Paulo: Unesp/CEM, 2015, v. 1, pp. 223-248.

MARTINS, Maria Lucia Refinetti. São Paulo: além do plano diretor. Estudos Avançados (USP. Impresso), São Paulo, v. 17, p. 167-186, 2003.

MARTINS, Maria Lucia Refinetti. O Estatuto da Cidade, marco referencial para a política urbana. In: Cadernos do IJB (Instituto Jorge Baptista), n. 1, Osasco, jun.2004.

MARTINS, Maria Lucia Refinetti. O Desafio Institucional. Texto preparado no âmbito dos debates de elaboração do PLANHAB, dez.2007.

MASSONETTO, Luís Fernando. Direito urbanístico - notas epistemológicas. In: BELLO, Enzo; KELLER, Rene José (Orgs.). Curso de direito à cidade: teoria e prática. 2a Edição. Rio de Janeiro : Editora Lumen Juris, 2019.

MELTZER, A. H.; RICHARD, S. F. A Rational Theory of the Size of Government. In: Journal of Political Economy, 89, pp. 914-27, 1981.

MENDES, Marcos José. Texto para discussão 39: Sistema orçamentário brasileiro: planejamento, equilíbrio fiscal e qualidade do gasto público. Disponível em: <http://www.senado.gov.br/conleg/textos_discussao.htm>, consultado em agosto de 2019. 
MIOTO, Beatriz Tamaso. As políticas habitacionais no subdesenvolvimento: os casos do Brasil, Colômbia, México e Venezuela (1980/2013). Tese apresentada ao Instituto de Economia da Universidade Estadual de Campinas, 2015.

NASCIMENTO, Denise Morado. A autoconstrução na produção do espaço urbano. In: Jupira Gomes de Mendonça; Heloísa Soares de Moura Costa. (Org.). Estado e capital imobiliário: convergências atuais na produção do espaço urbano brasileiro. 1ed.Belo Horizonte: C/Arte, 2011, v. , p. 217-230.

NASSIF, André. A valsa não totalmente afinada de Laura Carvalho: um ensaio-resenha crítico de Valsa brasileira: do boom ao caos econômico. CADERNOS DO DESENVOLVIMENTO, v. 13, p. 11, 2018.

NETO, Vicente Correia Lima. O efeito de investimentos em transporte público no valor dos imóveis: o caso do distrito federal. In: Boletim regional, urbano e ambiental / Instituto de Pesquisa Econômica Aplicada. Diretoria de Estudos e Políticas Regionais, Urbanas e Ambientais. Brasília : Ipea. Dirur, 2011.

NEY, M. G.; HOFFMANN, R. . Educação, concentração fundiária e desigualdade de rendimentos no meio rural brasileiro. Revista de Economia e Sociologia Rural (Impresso), v. 47, p. 147-181, 2009.

OLIVEIRA, Francisco de. Acumulação monopolista, Estado e urbanização: a nova qualidade do conflito de classes. In: MOISÉS, J. Á; MARTINEZ-ALIER, V; OLIVEIRA, F. de; SOUZA, S. de. Contradições urbanas e movimentos sociais. 3aed. Rio de Janeiro: Paz e Terra/CEDEC, 1978.

OLIVEIRA, Francisco de. A economia brasileira: crítica à razão dualista. Petrópolis: Editora Vozes, 1981 [1972].

OLIVEIRA, Francisco de. Prefácio. In: MARICATO, Ermínia. A produção capitalista da casa (e da cidade) no Brasil Industrial. 2. ed. São Paulo, SP: Alfa Omega, 1979.

OLIVEIRA, Francisco de. Eligia para uma re(li)gião: Sudene, Nordeste, Planejamento e Conflitos de Classes. 3a edição. Rio de Janeiro, Paz e Terra, 1981.

OLIVEIRA, Francisco de. O Estado e o urbano no Brasil. In: Revista Espaço \& Debates, n. 6, 1982.

OLIVEIRA, Francisco de. O surgimento do antivalor: capital, força de trabalho e fundo público. In: Novos Estudos CEBRAP, No 22, 1988, pp.8-28.

OLIVEIRA, Francisco de. A Metamorfose da Arribaça. NOVOS ESTUDOS CEBRAP, São Paulo - SP, v. 27, p. 67-92, 1990.

OLIVEIRA, Francisco de. Quem canta de novo I'Internationale?, 2005. In: OLIVEIRA, Francisco de. Brasil: Uma biografia não autorizada. Editora Boitempo, São Paulo, 2018.

OLIVEIRA, Francisco de. O adeus do futuro ao país do futuro: uma biografia breve do Brasil, 2006. In: OLIVEIRA, Francisco de. Brasil: Uma biografia não autorizada. Editora Boitempo, São Paulo, 2018.

OLIVEIRA, Francisco de. Hegemonia às avessas, 2007. In: OLIVEIRA, Francisco de. Brasil: Uma biografia não autorizada. Editora Boitempo, São Paulo, 2018.

OLIVEIRA, Francisco de. O avesso do avesso, 2009. In: OLIVEIRA, Francisco de. Brasil: Uma biografia não autorizada. Editora Boitempo, São Paulo, 2018.

OLIVEIRA, Francisco de. A clonagem, 2011. In: OLIVEIRA, Francisco de. Brasil: Uma biografia não autorizada. Editora Boitempo, São Paulo, 2018. 
OLIVEIRA, Francisco de. Jetinho e jeitão, 2012. In: OLIVEIRA, Francisco de. Brasil: Uma biografia não autorizada. Editora Boitempo, São Paulo, 2018.

OLIVEIRA, Francisco de. Brasil: Uma biografia não autorizada. Editora Boitempo, São Paulo, 2018.

OLIVEIRA, Isadora Fernandes Borges. Articulações entre as formas de produção do espaço no habitat popular latino-americano: custos de produção e preço da terra na produção doméstica e de mercado ? uma aproximação ao debate. In: XVIII Encontro Nacional da Associação Nacional de Pós-graduação e Pesquisa em Planejamento Urbano e Regional, 2019, Natal, Rio Grande do Norte. Anais do Encontro Nacional da Associação Nacional de Pós-graduação e Pesquisa em Planejamento Urbano e Regional. ENANPUR: Tempos em / de Transformação - Utopias. Natal: EDUFRN, 2019.

OLIVEIRA, Melissa Ronconi ; FIX, Mariana. Trabalho na construção civil durante a retomada do financiamento habitacional no Brasil. In: XVII Enanpur, 2017, São Paulo. Anais Enanpur, 2017.

OLIVEIRA, Paula Custódio. O CEU na integração da periferia. Dissertação de mestrado apresentada à Faculdade de Arquitetura e Urbanismo da Universidade de São Paulo, 2017.

OTERO, Estevam Vanale Reestruturação urbana em cidades médias paulistas: a cidade como negócio / Estevam Vanale Otero. -- São Paulo, 2016. 342p. :il. Tese (Doutorado - Área de Concentração: Planejamento Urbano e Regional) - FAUUSP.

PASTERNAK, S.; D'OTTAVIANO, C. Favelas no Brasil e em São Paulo: avanços nas análises a partir da Leitura Territorial do Censo de 2010. In: Cadernos Metrópole, 2016, vol.18, n.35, pp.75-100.

PAULANI, Leda Maria. A crise do regime de acumulação com dominância da valorização financeira e a situação do Brasil. Estudos Avançados (USP. Impresso), v. 23, p. 25-39, 2009.

PAULANI, Leda Maria. A inserção da economia brasileira no cenário mundial: uma reflexão sobre a situação atual à luz da história. In: Boletim de Economia e Política Internacional, v. 10, p. 89-102, 2012.

PAULANI, Leda Maria. Capitalismo e Estado no Brasil: a saga dos investimentos públicos. Politika, v. 1, p. 70-81, 2016.

PAULANI, Leda Maria. Não há saída sem a reversão da financeirização. Estud. av. 2017, vl.31, n.89 pp.2935.

PAULANI, Leda Maria. Desenvolvimentismo, planejamento e investimento público nos 5 mil dias de lulismo. In: Gilberto Maringoni e Juliano Medeiros. (Org.). 5 MIl Dias: o Brasil na era do lulismo. 1ed.São Paulo: Boitempo, 2017, v. , p. 57-69.

ROSSI, Pedro; DWECK, Esther; OLIVEIRA, Ana Luíza Matos de. (Org.). Economia para poucos: impactos sociais da austeridade e alternativas para o Brasil. 1ed.: , 2018.

PERES, Ursula Dias. Financiamento e políticas públicas educacionais: perspectiva normativa, dilemas e mudanças recentes. In: Revista Parlamento e Sociedade, v. 4, p. 65-101, 2016.

PERES, Ursula Dias. Análise da governança do orçamento público, 2018. In: Marques, E. (Org.). As políticas do urbano em São Paulo. São Paulo: Ed. Unesp, 2018.

PERES, Ursula Dias; SANTOS, Fabio Pereira dos. Orçamento-programa: incrementalismo, racionalismo e política. In: PIRES, Valdemir; SATHLER, André Rehbein (Orgs.). Gestão orçamentária inovadora: desafios e perspectivas no Brasil. Brasília : Senado Federal, Coordenação de Edições Técnicas, 2018. 
PERES, Ursula Dias; SANTOS, Fabio Pereira dos. Gasto Público e Desigualdade Social: O orçamento do governo federal brasileiro entre 1995 e 2016. Revista Brasileira de Ciências Sociais (Online), v. 35, 2020.

PIERSON, Paul. Coping with Permanent Austerity: welfare state restructuring in affluent democracies. In: PIERSON, Paul. The New Politics of the Welfare State. Oxford: Oxford University Press, 2001.

PIKETTY, Thomas. O capital no século XXI. Rio de Janeiro: Intrínseca, 2014.

POLANYI, Karl. A grande transformação: as origens de nossa época. Editora Campus, Rio de Janeiro, 2000.

PRATES, D. M.; FRITZ, B ; DE PAULA, LUIZ FERNANDO . Uma avaliação das políticas desenvolvimentistas nos governos do PT. CADERNOS DO DESENVOLVIMENTO, v. 12, p. 187-215, 2017.

PRZEWORSKI, Adam. Capitalismo e Social-democracia. São Paulo, Companhia das Letras, 1989.

REZENDE, Fernando Antonio. Finanças Públicas, 2 ed. 4 reimpr., São Paulo : Atlas, 2006.

RODRIGUES, Arlete Moysés. A Política Urbana no Governo Lula. In: Idéias, Revista do Instituto de Filosofia e Ciências Humanas (IFCH-UNICAMP), Campinas (SP), № 3, Nova Série, 2o Semestre de 2011.

ROYER, Luciana de Oliveira. Financeirização da Política Habitacional: Limites e Perspectivas. Tese de doutoramento apresentado à Universidade de São Paulo, 2009.

ROYER, Luciana de Oliveira. Municípios 'Autárquicos' e Região Metropolitana: A Questão Habitacional e os Limites Administrativos. In: FURTADO, Bernardo Alves; KRAUSE, Cleandro; FRANÇA, Karla Christina Batista de (Editores). Revista Território Metropolitano, políticas municipais: Por soluções conjuntas de problemas urbanos no âmbito metropolitano, Instituto de Pesquisa Econômica Aplicada, 2013.

ROYER, Luciana de Oliveira. O FGTS e o mercado de títulos de base imobiliária: relações e tendências. Cadernos Metrópole, v. 18, p. 33-52, 2016.

ROYER, L. O. ; SANTOS, F. P. ; FILOCOMO, G. . O financiamento do desenvolvimento urbano brasileiro: o papel da cooperação interfederativa no caso do município de São Paulo. In: XXXVI International Congress of the Latin American Studies Association, 2018, Barcelona. Latin American Studies in a Globalized World, 2018.

ROYER, L. O. ; FILOCOMO, G. . Conflitos e significados em torno da casa e da cidade durante os governos federais petistas. In: XVIII Encontro Nacional da Associação Nacional de Pós-graduação e Pesquisa em Planejamento Urbano e Regional, 2019, Natal. Encontro Nacional da Associação Nacional de Pósgraduação e Pesquisa em Planejamento Urbano e Regional ? ENANPUR: Tempos em / de Transformação ? Utopias (2019 : Natal). Natal: EDUFRN, 2019.

ROYER, L. O. ; PERES, U. D. ; FILOCOMO, G. ; VIEIRA, A. D. . Produção do espaço urbano e finanças contemporâneas: o papel do fundo público. In: XVIII Encontro Nacional da Associação Nacional de Pósgraduação e Pesquisa em Planejamento Urbano e Regional, 2019, Natal. Encontro Nacional da Associação Nacional de Pós-graduação e Pesquisa em Planejamento Urbano e Regional ? ENANPUR: Tempos em / de Transformação ? Utopias (2019 : Natal). Natal: EDUFRN, 2019.

RUFINO, M. B. C.; PEREIRA, PCX. Segregação e produção imobiliária na transformação da metrópole latinoamericana: um olhar a partir da cidade de São Paulo. In: LENCIONI, Sandra ; VIDAL-KOPPMANN, Sonia ; HIDALGO, Rodrigo ; PEREIRA, Paulo Cesar Xavier Pereira.. (Org.). Transformações sócio-territoriais nas metrópoles de Buenos Aires, São Paulo e Santiago.. 1ed.São Paulo: , 2011, v. , p. 65-84. 
RUFINO, Maria Beatriz Cruz. Um olhar sobre a produção do PMCMV a partir de eixos analíticos. In SANTO AMORE, Caio; SHIMBO, Lucia Z.; RUFINO, M. Beatriz C. (Orgs.) Minha casa... e a cidade? avaliação do programa minha casa minha vida em seis estados brasileiros. Rio de Janeiro: Letra Capital, 2015, págs 51-72.

RUFINO, Maria Beatriz Cruz. Transformação da periferia e novas formas de desigualdades nas metrópoles brasileiras: um olhar sobre as mudanças na produção habitacional. Cadernos Metrópole (PUCSP), v. I, p. 217, 2016.

RUFINO, Maria Beatriz Cruz. Financeirização do Imobiliário e transformações na produção do espaço. In: Alvaro Ferreira; João Rua; Regina Celia de Mattos. (Org.). O espaço e a metropolização: cotidiano e ação. 1ed. Rio de Janeiro: Consequência, 2017, v. 1, p. 213-240.

RUGITSKY, Fernando Monteiro. Outra fantasia desfeita, outro balanço crítico. In: Novos Estudos. CEBRAP, v. 37, p. 169-173, 2018.

SABOIA, João. Baixo crescimento econômico e melhora do mercado de trabalho - Como entender a aparente contradição?. Estudos Avançados (USP. Impresso), v. 28, p. 115-125, 2014.

SAMPAIO, J. A. Construções: Imagens, discursos e narrativas na Brasília de Thomaz Farkas. 2016. Dissertação (Mestrado) - Faculdade de Filosofia Letras e Ciências Humanas, Universidade de São Paulo, São Paulo, 2016.

SANTO AMORE, Caio; SHIMBO, Lucia Z.; RUFINO, RUFINO, Maria Beatriz Cruz. (Orgs.) Minha casa... e a cidade? avaliação do programa minha casa minha vida em seis estados brasileiros. Rio de Janeiro: Letra Capital, 2015.

SANTOS, Fabio Pereira dos. Notas sobre o financiamento das políticas públicas no Brasil e na cidade de São Paulo. In: Revista Parlamento \& Sociedade, v. 4, p. 15-32, 2016.

SANTOS, Jonatas M. dos. Financiamento do Desenvolvimento Urbano: Normas, Eventos e Instrumentos Urbanísticos na Cidade de São Paulo. Dissertação - Programa de Pós-Graduação em Geografia Humana, Universidade de São Paulo, 2012

SATHLER, D.; MONTE-MOR, R. L. M. ; CARVALHO, J. A. M. . As redes para além dos rios: urbanização e desequilíbrios na Amazônia Brasileira (ISSN: 0103-6351). NOVA ECONOMIA (UFMG. IMPRESSO), v. 19, p. 10-39, 2009.

SCHÄFER, Armin; STREECK, Wolfgang. Politics in the Age of Austerity. Polity Press, 2013.

SCHICK, Allen. O PPB e o orçamento incremental. In: Revista de Administração Pública, v. 10, n. 2, p. 6584, 1976.

SECRETO, María Verónica. Legislação sobre terras no Brasil do oitocentos: definindo a propriedade. In: Raizes. Revista de Ciências Sociais e Econômicas, v. 26, p. 10-20, 2007.

SERRANO, Franklin; SUMMA, Ricardo. Conflito distributivo e o fim da "breve era de ouro" da economia brasileira. Novos Estudos. CEBRAP, v. 37, p. 175-189, 2018.

SíGOLO, Leticia M. O boom imobiliário redesenhando a cartografia da segregação socioespacial na metrópole paulistana. In: ANAIS XVI Encontro Nacional da ANPUR, Belo Horizonte, 2015. 
SILVA, Marlon Lima Da; TOURINHO, Helena Lúcia Zagury. O Banco Nacional de Habitação e o Programa Minha Casa Minha Vida: duas políticas habitacionais e uma mesma lógica locacional. Cadernos Metrópole, v. 17, p. 401-417, 2015

SINGER, André Vitor. Raízes sociais e ideológicas do lulismo. Novos Estudos CEBRAP, v. 85, p. 83-99, 2009.

SINGER, André Vitor. Cutucando onças com varas curtas. Novos Estudos CEBRAP, v. 102, p. 43-71-71, 2015.

SINGER, André Vitor. Democracia e desigualdade na América Latina. Os impasses atuais da América Latina. Apresentação realizada em Seminário "Democracia e desigualdade na América Latina. Os impasses atuais da América Latina", São Paulo, 19/09/2018. Disponível em: <https://www.fflch.usp.br/860>, consultado em novembro de 2018.

SINGER, Paul. Economia política da urbanização. São Paulo. Brasiliense, 1980 [1973].

SMITH, Roberto. A Renda do Escravo no Quadro da Acumulação Mercantil Colonial [s.i.].

SMITH, Roberto. O estado e a formação da propriedade da terra no Brasil. In: SMITH, Roberto. Propriedade da Terra e Transição - Estudo da formação da Propriedade Privada da Terra e Transição para o Capitalismo no Brasil. São Paulo: Editora Brasiliense, 1990.

SOARES, Sergei Suarez Dillon. Distribuição de Renda no Brasil de 1976 a 2004 com ênfase entre 2001 e 2004. Texto para Discussão IPEA no. 1166, 2006.

SOARES, Sergei Suarez Dillon. O ritmo na queda da desigualdade no Brasil é aceitável? In: Revista de Economia Política, v. 30, p. 364-380, 2010.

SOARES, Sergei Suarez Dillon. Texto para discussão: Valor de mercado de acesso a eletricidade, água, esgoto, gás e telefonia fixa. Instituto de Pesquisa Econômica Aplicada. Brasília : Rio de Janeiro : Ipea, 2017.

SOUZA, Diego Beja Inglez de. Tumulto no conjunto: Habitação, utopia e urbanização nos limites de duas metrópoles contemporâneas São Paulo - Paris (1960-2010). Tese apresentada à Faculdade de Arquitetura e Urbanismo da Universidade de São Paulo e à Université Paris 1 Panthéon-Sorbonne para obtenção do título de Doutor em História da Arquitetura e do Urbanismo.

SOUZA, Guaraci Adeodato A de; FARIA, Vilmar. Bahia de todos os pobres. Editora Vozes em co-edição com CEBRAP, 1980.

SOUZA, Pedro H.G.F.. A history of inequality: Top incomes in Brazil, 1926-2015. Research in Social Stratification and Mobility, v. 57, p. 35-45, 2018.

STREECK, Wolfgang. The politics of public debt: Neoliberalism, capitalist development and the restructuring of the state. German Economic Review, v. 15, n. 1, p. 143-165, 2014.

TAVARES, Maria da Conceição de Almeida. Império, Território e Dinheiro. In: J. L. Fiori. (Org.). Estados e Moedas no Desenvolvimento das Nações. Petrópolis: Vozes, 1999.

TAVARES, Maria da Conceição de Almeida. Restaurar o Estado é preciso. In: MELO, Hildete Pereira de (Org.). Maria da Conceição Tavares: vida, ideias, teorias e política. São Paulo: Fundação Perseu Abramo, 2019. 
TELLES, V. S.. Favela, favelas: interrogando mitos, dogmas e representações. Resenha do livro de Licia do Prado VALLADARES. A invenção da favela: do mito de origem à favela (Rio de Janeiro, Editora FGV, 2005. 204 páginas.). In: Revista Brasileira de Ciencias Sociais, vol. 21, no. 62, out. Sao Paulo 2006 (Resenha).

TOPALOV, Christian. Les Promoteurs immobiliers: Contribution à l'analyse de la production capitaliste du logement en France. Paris: Editora Mouton, 1974.

VAINER, Carlos Bernardo. As escalas do poder e o poder das escalas: o que pode o poder local? Cadernos IPPUR. Rio de Janeiro: IPPUR, ano XV, n.2, ago/dez, 2001 e jan/jul, 2002.

VIANNA, Rejane Jung.A valorização das terras situadas na região da bacia do rio São Bartolomeu: a 3a ponte do Lago Sul e os condomínios fechados. In: Boletim regional, urbano e ambiental / Instituto de Pesquisa Econômica Aplicada. Diretoria de Estudos e Políticas Regionais, Urbanas e Ambientais. Brasília : Ipea. Dirur, 2011.

WISSENBACH, Thomas. Gasto público no território e o território do gasto na política pública: um estudo sobre a territorialização do gasto público na cidade de São Paulo 2014-2017. Estudo disponível em: <https://ceapg.fgv.br/sites/ceapg.fgv.br/files/relatorio_gasto_publico_final.pdf>, consultado em setembro de 2019.

\section{Legislação}

BRASIL, 1964. LEI № 4.380, DE 21 DE AGOSTO DE 1964.Institui a correção monetária nos contratos imobiliários de interesse social, o sistema financeiro para aquisição da casa própria, cria o Banco Nacional da Habitação (BNH), e Sociedades de Crédito Imobiliário, as Letras Imobiliárias, o Serviço Federal de Habitação e Urbanismo e dá outras providências.

BRASIL, 1964. LEI № 4.591, DE 16 DE DEZEMBRO DE 1964.Dispõe sobre o condomínio em edificações e as incorporações imobiliárias.

BRASIL, 1969. DECRETO-LEI № 949, DE 13 DE OUTUBRO DE 1969.Dispõe sobre aplicações de recursos pelo BNH nas operações de financiamento para Saneamento e dá outras providências.

BRASIL, 1971. LEI № 5.762, DE 14 DE DEZEMBRO DE 1971. Transforma o Banco Nacional da Habitação (BNH) em empresa pública, e dá outras providências.

BRASIL, 1973. LEI COMPLEMENTAR № 14, DE 8 DE JUNHO DE 1973. Estabelece as regiões metropolitanas de São Paulo, Belo Horizonte, Porto Alegre, Recife, Salvador, Curitiba, Belém e Fortaleza.

BRASIL, 1978. DECRETO No 82.587, DE 6 DE NOVEMBRO DE 1978. Regulamenta a Lei no 6.528, de 11 de maio de 1978, que dispõe sobre as tarifas dos serviços públicos de saneamento e dá outras providências.

BRASIL, 1979. LEI № 6.766, DE 19 DE DEZEMBRO DE 1979. Dispõe sobre o Parcelamento do Solo Urbano e dá outras Providências.

BRASIL, 1980. LEI № 6.803, DE 2 DE JULHO DE 1980.Dispõe sobre as diretrizes básicas para o zoneamento industrial nas áreas críticas de poluição, e dá outras providências.

BRASIL, 1986. DECRETO-LEI № 2.291, DE 21 DE NOVEMBRO DE 1986. Extingue o Banco Nacional da Habitação - BNH e dá outras providências.

BRASIL, 1988. CONSTITUIÇÃO DA REPÚBLICA FEDERATIVA DO BRASIL DE 1988. 
BRASIL, 1999. LEI № 9.785, DE 29 DE JANEIRO DE 1999.Altera o Decreto-Lei no 3.365, de 21 de junho de 1941 (desapropriação por utilidade pública) e as Leis nos 6.015, de 31 de dezembro de 1973 (registros públicos) e 6.766, de 19 de dezembro de 1979 (parcelamento do solo urbano).

BRASIL, 2000. EMENDA CONSTITUCIONAL № 26, DE 14 DE FEVEREIRO DE 2000. Altera a redação do art. 60 da Constituição Federal. (Moradia incorporada ao rol dos direitos sociais).

BRASIL, 2000. Lei Federal № 9.989, de 21 de julho de 2000.

BRASIL, 2000. Lei Federal № 9.995, de 25 de julho de 2000.

BRASIL, 2001. Lei Federal № 10.266, de 24 de julho de 2001.

BRASIL, 2001. LEI № 10.257, DE 10 DE JULHO DE 2001.Regulamenta os arts. 182 e 183 da Constituição Federal, estabelece diretrizes gerais da política urbana e dá outras providências.

BRASIL, 2001. MEDIDA PROVISÓRIA No 2.220, DE 4 DE SETEMBRO DE 2001.Dispõe sobre a concessão de uso especial de que trata o § 1odo art. 183 da Constituição, cria o Conselho Nacional de Desenvolvimento Urbano - CNDU e dá outras providências.

BRASIL, 2002. Lei Federal № 10.524, de 25 de julho de 2002.

BRASIL, 2003. Lei Federal № 10.707, de 30 de julho de 2003.

BRASIL, 2004. Lei Federal № 10.933, de 11 de agosto de 2004.

BRASIL, 2004. Lei Federal № 10.934, de 11 de agosto de 2004.

BRASIL, 2004. LEI № 11.079, DE 30 DE DEZEMBRO DE 2004.Institui normas gerais para licitação e contratação de parceria público-privada no âmbito da administração pública.

BRASIL, 2005. Lei Federal № 11.178, de 20 de setembro de 2005.

BRASIL, 2005. LEI № 11.107, DE 6 DE ABRIL DE 2005.Dispõe sobre normas gerais de contratação de consórcios públicos e dá outras providências.

BRASIL, 2005. LEI № 11.124, DE 16 DE JUNHO DE 2005.Dispõe sobre o Sistema Nacional de Habitação de Interesse Social - SNHIS, cria o Fundo Nacional de Habitação de Interesse Social - FNHIS e institui o Conselho Gestor do FNHIS.

BRASIL, 2006. Lei Federal № 11.439, de 29 de dezembro de 2006.

BRASIL, 2007. Lei Federal № 11.514, de 13 de agosto de 2007.

BRASIL, 2007. LEI № 11.445, DE 5 DE JANEIRO DE 2007.Estabelece diretrizes nacionais para o saneamento básico; altera as Leis nos 6.766, de 19 de dezembro de 1979, 8.036, de 11 de maio de 1990, 8.666, de 21 de junho de 1993, 8.987, de 13 de fevereiro de 1995; revoga a Lei no 6.528, de 11 de maio de 1978; e dá outras providências.

BRASIL, 2008. Lei Federal № 11.653, de 07 de abril de 2008.

BRASIL, 2008. Lei Federal № 11.768, de 14 de agosto de 2008.

BRASIL, 2009. Lei Federal № 12.017, de 12 de agosto de 2009.

BRASIL, 2010. Lei Federal № 12309, de 09 de agosto de 2010. 
BRASIL, 2010. LEI № 12.305, DE 2 DE AGOSTO DE 2010.Institui a Política Nacional de Resíduos Sólidos; altera a Lei no 9.605, de 12 de fevereiro de 1998; e dá outras providências.

BRASIL, 2011. Lei № 12.462, de 4 de agosto de 2011: Institui o Regime Diferenciado de Contratações Públicas - RDC; altera a Lei no 10.683, de 28 de maio de 2003, que dispõe sobre a organização da Presidência da República e dos Ministérios, a legislação da Agência Nacional de Aviação Civil (Anac) e a legislação da Empresa Brasileira de Infraestrutura Aeroportuária (Infraero); cria a Secretaria de Aviação Civil, cargos de Ministro de Estado, cargos em comissão e cargos de Controlador de Tráfego Aéreo; autoriza a contratação de controladores de tráfego aéreo temporários; altera as Leis nos 11.182, de 27 de setembro de 2005, 5.862, de 12 de dezembro de 1972, 8.399, de 7 de janeiro de 1992, 11.526, de 4 de outubro de 2007, 11.458, de 19 de março de 2007, e 12.350, de 20 de dezembro de 2010, e a Medida Provisória no 2.185-35, de 24 de agosto de 2001; e revoga dispositivos da Lei № 9.649, de 27 de maio de 1998

BRASIL, 2012. Lei Federal № 12.593, de 18 de janeiro de 2012.

BRASIL, 2012. LEI № 12.587, DE 3 DE JANEIRO DE 2012.Institui as diretrizes da Política Nacional de Mobilidade Urbana; revoga dispositivos dos Decretos-Leis no 3.326, de 3 de junho de 1941, e 5.405, de 13 de abril de 1943, da Consolidação das Leis do Trabalho (CLT), aprovada pelo Decreto-Lei no 5.452, de 1 ㅇ de maio de 1943, e das Leis no 5.917, de 10 de setembro de 1973, e 6.261, de 14 de novembro de 1975; e dá outras providências.

BRASIL, 2015. LEI № 13.089, DE 12 DE JANEIRO DE 2015. Institui o Estatuto da Metrópole, altera a Lei no 10.257, de 10 de julho de 2001, e dá outras providências.

BRASIL, 2016. Lei Federal № 13.249, de 13 de janeiro de 2016.

BRASIL, 2017. LEI № 13.465, DE 11 DE JULHO DE 2017.Dispõe sobre a regularização fundiária rural e urbana, sobre a liquidação de créditos concedidos aos assentados da reforma agrária e sobre a regularização fundiária no âmbito da Amazônia Legal; institui mecanismos para aprimorar a eficiência dos procedimentos de alienação de imóveis da União; altera as Leis n os 8.629, de 25 de fevereiro de 1993 , 13.001, de 20 de junho de 2014 , 11.952, de 25 de junho de 2009, 13.340, de 28 de setembro de 2016, 8.666, de 21 de junho de 1993, 6.015, de 31 de dezembro de 1973,12.512, de 14 de outubro de 2011 , 10.406, de 10 de janeiro de 2002 (Código Civil), 13.105, de 16 de março de 2015 (Código de Processo Civil), 11.977, de 7 de julho de 2009, 9.514, de 20 de novembro de 1997, 11.124, de 16 de junho de 2005, 6.766, de 19 de dezembro de 1979, 10.257, de 10 de julho de 2001, 12.651, de 25 de maio de 2012, 13.240, de 30 de dezembro de 2015, 9.636, de 15 de maio de 1998, 8.036, de 11 de maio de 1990,13.139, de 26 de junho de 2015, 11.483, de 31 de maio de 2007, e a 12.712, de 30 de agosto de 2012, a Medida Provisória no 2.220, de 4 de setembro de 2001, e os Decretos-Leis n 2.398, de 21 de dezembro de 1987,1.876, de 15 de julho de 1981, 9.760, de 5 de setembro de 1946, e 3.365, de 21 de junho de 1941; revoga dispositivos da Lei Complementar no 76, de 6 de julho de 1993, e da Lei no 13.347, de 10 de outubro de 2016; e dá outras providências.

BRASIL, 2018. MEDIDA PROVISÓRIA № 844, DE 6 DE JULHO DE 2018. Atualiza o marco legal do saneamento básico e altera a Lei no 9.984, de 17 de julho de 2000, para atribuir à Agência Nacional de Águas competência para editar normas de referência nacionais sobre o serviço de saneamento, a Lei no 10.768, de 19 de novembro de 2003, para alterar as atribuições do cargo de Especialista em Recursos Hídricos, e a Lei no 11.445, de 5 de janeiro de 2007, para aprimorar as condições estruturais do saneamento básico no País. 


\section{Portais eletrônicos}

$<$ http://agencia.fapesp.br/belo-monte-descumpriu-promessa-de-levar-desenvolvimento-sustentavel-aregiao-amazonica/31374/>, consultado em setembro de 2019.

<http://brasildebate.com.br/wp-content/uploads/vinte-anos-de-economia-brasileira-1994-2016-abril2017-compressed.pdf>, consultado em outubro de 2018.

<http://paineldeobras.planejamento.gov.br/>.

<http://portalfat.mte.gov.br/codefat/resolucoes-2/resolucoes-por-assunto/geracao-de-emprego-erenda/linhas-de-creditos-especiais/fat-giro-cooperativo-agropecuario/sobre-o-fat/>, consultado em agosto de 2019.

<http://sishab.cidades.gov.br/>, consultado em setembro de 2019.

<http://trensurb.gov.br/paginas/paginas_detalhe.php?codigo_sitemap=48>, consultado em novembro de 2019.

$<$ http://www.caixa.gov.br/>.

$<$ http://www.camara.leg.br/>.

$<$ http://www.orcamentofederal.gov.br/>.

$<$ http://www.orcamentofederal.gov.br/clientes/portalsof/portalsof/orcamentos-anuais/orcamento2005-1/orcamentos_anuais_view?anoOrc=2005>, consultado em setembro de 2018.

<http://www.orcamentofederal.gov.br/clientes/portalsof/portalsof/orcamentos-anuais/orcamento2006/orcamentos_anuais_view?anoOrc=2006>, consultado em setembro de 2018.

<http://www.orcamentofederal.gov.br/clientes/portalsof/portalsof/orcamentos-anuais/orcamento2007/orcamentos_anuais_view?anoOrc=2007>, consultado em setembro de 2018.

<http://www.orcamentofederal.gov.br/clientes/portalsof/portalsof/orcamentos-anuais/orcamento2008/orcamentos_anuais_view?anoOrc=2008>, consultado em setembro de 2018.

<http://www.orcamentofederal.gov.br/clientes/portalsof/portalsof/orcamentos-anuais/orcamento2009/orcamentos_anuais_view?anoOrc=2009>, consultado em setembro de 2018.

<http://www.orcamentofederal.gov.br/clientes/portalsof/portalsof/orcamentos-anuais/orcamento2010/orcamentos_anuais_view?anoOrc=2010>, consultado em setembro de 2018.

<http://www.orcamentofederal.gov.br/clientes/portalsof/portalsof/orcamentos-anuais/orcamento2011/orcamentos_anuais_view?anoOrc=2011>, consultado em setembro de 2018.

$<$ http://www.orcamentofederal.gov.br/clientes/portalsof/portalsof/orcamentos-anuais/orcamento2013-1/orcamentos_anuais_view?anoOrc=2013>, consultado em setembro de 2018.

<http://www.orcamentofederal.gov.br/clientes/portalsof/portalsof/orcamentos-anuais/orcamento2014/arquivos-LDO/Anexo\%20VII.pdf]>, consultado em setembro de 2018.

<http://www.orcamentofederal.gov.br/clientes/portalsof/portalsof/orcamentos-anuais/orcamento2014/orcamentos_anuais_view?anoOrc=2014>, consultado em setembro de 2018. 
<http://www.orcamentofederal.gov.br/clientes/portalsof/portalsof/orcamentos-anuais/orcamento2015-2/orcamentos_anuais_view?anoOrc=2015>, consultado em setembro de 2018.

<http://www.orcamentofederal.gov.br/informacoes-orcamentarias/manualtecnico/mto_2016_1aedicao-200515.pdf>, consultado em outubro de 2019.

$<$ http://www.planalto.gov.br/>.

<http://www.planalto.gov.br/ccivil_03/constituicao/constituicao.htm>, consultado em agosto de 2019. <http://www.planalto.gov.br/ccivil_03/Exm/2002/203-MF-02.htm>, consultado em outubro de 2019. <http://www.planalto.gov.br/ccivil_03/Exm/2003/EMI151-MF-MME-MDIC-03.htm>, consultado em outubro de 2019.

<http://www.planalto.gov.br/ccivil_03/LEIS/2002/L10438.htm>, consultado em outubro de 2019. <http://www.planalto.gov.br/ccivil_03/LEIS/2002/L10524.htm>, consultado em setembro de 2018. <http://www.planalto.gov.br/ccivil_03/LEIS/2003/L10.707.htm>, consultado em setembro de 2018. <http://www.planalto.gov.br/ccivil_03/leis/L9811.htm>, consultado em setembro de 2018. <http://www.planalto.gov.br/CCIVIL_03/LEIS/L9995.htm>, consultado em setembro de 2018. <http://www.planalto.gov.br/ccivil_03/LEIS/LEIS_2001/L10266.htm>, consultado em setembro de 2018.

<http://www.planejamento.gov.br/>.

<http://www.planejamento.gov.br/assuntos/planeja/plano-plurianual/>, consultado em setembro de 2018.

<http://www.portaltransparencia.gov.br/orcamento?ano=2018>, consultado em setembro de 2019 <http://www.transparencia.gov.br/>.

<http://www2.camara.leg.br/legin/fed/lei/2003/lei-10707-30-julho-2003-492035-normaatualizadapl.html>, consultado em setembro de 2018.

<http://www2.camara.leg.br/orcamento-da-uniao/leis-orcamentarias/ldo/2016/tramitacao/redacaofinal/LDO_2016_LEI_13242_2016.html>, consultado em setembro de 2018.

<http://www2.camara.leg.br/orcamento-da-uniao/leis-orcamentarias/ldo>, consultado em setembro de 2018.

<https://cidades.ibge.gov.br/brasil/am/nhamunda/panorama>, consultado em novembro de 2019.

<https://fundosdegoverno.caixa.gov.br/sicfg/fundos/FCVS/detalhe/sobre/>, consultado em novembro de 2019.

$<$ https://portal.tcu.gov.br/inicio/>.

<https://seriesestatisticas.ibge.gov.br/>, consultado em julho de 2019.

<https://valor.globo.com/brasil/noticia/2019/10/03/em-meio-a-crise-fiscal-contratos-de-pppscrescem-1625.ghtml>, link consultado em outubro de 2019. 
<https://www.caixa.gov.br/Downloads/habitacao-minha-casa-minha-vida/_Legislacao_FAR.pdf>, situação julho de 2018, consultado em outubro de 2019.

$<$ https://www.cps.fgv.br/cps/bd/slides/SLIDE-NOTA-

Dis_Pobreza_Desigualdade_Crise_Neri_FGV_Social_FGV.pdf>, consultado em julho de 2019.

$<$ https://www.google.com/url?sa=t\&rct=j\&q=\&esrc=s\&source=web\&cd=1\&ved=2ahUKEwjt-

4y84MHIAhVEHbkGHYFVDM8QFjAAegQIAhAC\&url=https\%3A\%2F\%2Fportal.tcu.gov.br\%2Flumis\%2Fpo rtal\%2Ffile\%2FfileDownload.jsp\%3Ffileld\%3D8A8182A24F0A728E014F0AE28A346938\&usg=AOvVaw2 w_gPjUYSycvZ_y2CIXpNg>, consultado em outubro de 2019.

<https://www.nexojornal.com.br/expresso/2019/07/21/Como-a-construção-civil-ajuda-a-explicar-acrise-brasileira>, consultado em setembro de 2019.

$<$ https://www.senado.leg.br/>.

<https://www.siop.planejamento.gov.br/>.

<https://www.valor.com.br/brasil/3357378/empregos-formais-no-pais-crescem-657-em-dez-anosindica-ibge>, consultado em setembro de 2019.

<https://www.valor.com.br/brasil/3675334/construcao-civil-recua-87-e-tem-maior-queda-desde2002>, consultado em setembro de 2019.

<https://www.valor.com.br/brasil/3859466/emprego-na-construcao-civil-cai-em-2014-diz-sinduscon>, consultado em setembro de 2019.

<https://www.valor.com.br/brasil/3881606/lava-jato-derruba-projecoes-de-pib-e-investimento>, consultado em setembro de 2019.

<https://www.valor.com.br/brasil/3935804/setor-de-construcao-deve-ter-bienio-perdido>, consultado em setembro de 2019.

<https://www.valor.com.br/brasil/3957038/kassab-diz-que-nova-fase-do-minha-casa-minha-vida-vaigerar-empregos, consultado em setembro de 2019.

<https://www.valor.com.br/brasil/3963526/ministerio-pretende-medir-impacto-da-lava-jato-nareducao-do-emprego-formal>, consultado em setembro de 2019.

<https://www.valor.com.br/brasil/4071964/obras-de-infraestrutura-contem-retracao-no-para>, consultado em setembro de 2019.

$<$ https://www.valor.com.br/brasil/4165968/sinduscon-sp-preve-queda-maior-para-pib-da-construcaodeste-ano>, consultado em setembro de 2019.

<https://www.valor.com.br/brasil/4241844/cortes-no-pac-e-minha-casa-minha-vida-afetamconfianca-da-construcao>, consultado em setembro de 2019.

<https://www.valor.com.br/brasil/4289144/lava-jato-contribuiu-para-o-aumento-do-desemprego-dizipea>, consultado em setembro de 2019.

<https://www.valor.com.br/brasil/4540109/retomada-de-obras-exige-recursos-do-banco-diz-fgv>, consultado em setembro de 2019. 
<https://www.valor.com.br/brasil/4643527/construcao-apoia-temer-mas-quer-obras>, consultado em setembro de 2019.

<https://www.valor.com.br/brasil/6170641/mais-de-37-milhoes-de-lares-do-brasil-tem-renda-muitobaixa-nota-ipea>, consultado em setembro de 2019.

<https://www.valor.com.br/brasil/6300911/pais-precisa-investir-4-do-pib-em-infraestrutura-dizconsultor>, consultado em setembro de 2019.

<https://www.valor.com.br/empresas/3566712/abramat-e-sinduscon-sp-reduzem-previsao-decrescimento>, consultado em setembro de 2019.

<https://www.valor.com.br/empresas/3888954/nivel-de-emprego-na-construcao-civil-cai-apos-doisanos-de-alta>, consultado em setembro de 2019.

$<$ https://www.valor.com.br/empresas/4086510/para-sinduscon-sp-investimentos-do-pacote-deconcessoes-sao-positivos>, consultado em setembro de 2019.

<https://www.valor.com.br/empresas/4346912/setor-de-construcao-encolhe-8-neste-ano-e-prevequeda-de-5-em-2016>, consultado em setembro de 2019.

<https://www.valor.com.br/empresas/4412706/construcao-fecha-483-mil-postos-de-trabalho-em2015-diz-sinduscon-sp>, consultado em setembro de 2019.

<https://www.valor.com.br/empresas/4567719/continuidade-do-minha-casa-minha-vida-eestrategica>, consultado em setembro de 2019.

<https://www.valor.com.br/empresas/4793401/sinduscon-sp-emprego-no-mercado-imobiliario-caiquase-18-em-10-meses>, consultado em setembro de 2019.

<https://www.valor.com.br/empresas/6202381/ccr-quer-investir-em-novos-projetos-deinfraestrutura>, consultado em setembro de 2019.

<https://www.valor.com.br/financas/6203055/infraestrutura-e-alvo-prioritario-em-atuacao-deagencias $>$, consultado em setembro de 2019.

<https://www.youtube.com/watch?v=_d5fJRzT3dY>, link consultado em julho de 2019.

<https://www.youtube.com/watch?v=fF-hGyhr0-8>, consultado em julho de 2019

<https://www.youtube.com/watch?v=fF-hGyhr0-8>, consultado em julho de 2019.

<https://www.youtube.com/watch?v=K_qunKjZf4U>, consultado em setembro de 2019.

<https://www.youtube.com/watch?v=MXTWnpSNL_M>, consultado em setembro de 2019.

<https://www.youtube.com/watch?v=wLz-_nXmh_E>, link consultado em agosto de 2019.

<https://www1.folha.uol.com.br/mercado/2019/10/governo-deve-r-500-mi-para-empreiteiras-dominha-casa-minha-vida.shtml>, consultado em outubro de 2019.

<https://www12.senado.leg.br/orcamento/documentos/legislacao/ldo/2000/410-lei-no-9-811-Ido2000-pdf/view>, consultado em setembro de 2018.

<https://www12.senado.leg.br/orcamento/documentos/legislacao/ldo/2001/410-lei-no-9-995-Ido2001-pdf/view>, consultado em setembro de 2018. 
<https://www12.senado.leg.br/orcamento/documentos/legislacao/Ido/2002/410-lei-no-10-266-Ido2002-pdf/view>, consultado em setembro de 2018.

<https://www12.senado.leg.br/orcamento/documentos/legislacao/ldo/2003/410-lei-no-10-524-Ido2003-pdf/view>, consultado em setembro de 2018.

<https://www12.senado.leg.br/orcamento>.

<https://youtu.be/XCENYLX9OtY>, consultado em outubro de 2019.

<orçamento.sf.prefeitura.sp.gov.br>.

<transparência.prefeitura.sp.gov.br>. 


\section{Anexos}

\begin{tabular}{|c|c|c|c|c|c|}
\hline Ano & $\begin{array}{l}\text { Valores Executados } \\
\text { OGU } \\
\text { (Empenhado; } \\
\text { Ano referência 2016) }\end{array}$ & $\begin{array}{l}\text { Valores Executados } \\
\text { OGU } \\
\text { (Liquidado; } \\
\text { Ano referência 2016) }\end{array}$ & $\begin{array}{l}\text { Evolução } \\
\text { Produto } \\
\text { Interno } \\
\text { Bruto } \\
\text { Real (\%) }\end{array}$ & $\begin{array}{l}\text { Resultado } \\
\text { primário } \\
\text { setor } \\
\text { público } \\
\text { (\% PIB) }\end{array}$ & $\begin{array}{l}\text { Investimento } \\
\text { público federal } \\
\text { (\%PIB) } \\
\text { (desconsideradas } \\
\text { as estatais) }\end{array}$ \\
\hline 2000 & $R \$ 1.756 .701 .646 .555$ & $R \$ 1.756 .690 .169 .537$ & - & - & - \\
\hline 2001 & $R \$ 1.599 .102 .713 .303$ & $R \$ 1.599 .102 .390 .557$ & 1,4 & 3,8 & 0,8 \\
\hline 2002 & $R \$ 1.613 .128 .065 .532$ & $R \$ 1.613 .078 .135 .100$ & 3,1 & 3,9 & 0,8 \\
\hline 2003 & $R \$ 1.884 .472 .161 .125$ & $R \$ 1.884 .381 .802 .823$ & 1,1 & 4,3 & 0,3 \\
\hline 2004 & $\mathrm{R} \$ 1.825 .443 .825 .310$ & $R \$ 1.825 .437 .315 .742$ & 5,8 & 4,6 & 0,5 \\
\hline 2005 & $R \$ 2.091 .836 .577 .974$ & $R \$ 2.091 .834 .482 .269$ & 3,2 & 4,8 & 0,5 \\
\hline 2006 & $R \$ 2.178 .029 .114 .736$ & $R \$ 2.178 .028 .589 .436$ & 4,0 & 3,2 & 0,6 \\
\hline 2007 & $R \$ 2.153 .886 .320 .983$ & $R \$ 2.068 .845 .156 .344$ & 6,1 & 3,3 & 0,7 \\
\hline 2008 & $R \$ 2.089 .695 .760 .910$ & $R \$ 2.003 .095 .682 .604$ & 5,1 & 3,4 & 0,9 \\
\hline 2009 & $R \$ 2.252 .030 .547 .549$ & $R \$ 2.143 .651 .835 .191$ & $-0,1$ & 2,0 & 1,0 \\
\hline 2010 & $R \$ 2.257 .426 .748 .697$ & $R \$ 2.148 .892 .205 .306$ & 7,5 & 2,8 & 1,2 \\
\hline 2011 & $R \$ 2.364 .332 .170 .998$ & $R \$ 2.243 .200 .639 .345$ & 4,0 & 3,1 & 1,0 \\
\hline 2012 & $R \$ 2.465 .326 .196 .093$ & $R \$ 2.319 .830 .946 .538$ & 1,9 & 2,4 & 1,0 \\
\hline 2013 & $R \$ 2.432 .307 .652 .295$ & $R \$ 2.278 .653 .688 .346$ & 3,0 & 1,7 & 0,9 \\
\hline 2014 & $R \$ 2.746 .919 .234 .630$ & $R \$ 2.615 .193 .665 .788$ & 0,5 & $-0,6$ & 1,0 \\
\hline 2015 & $R \$ 2.548 .785 .550 .475$ & $R \$ 2.465 .542 .279 .524$ & $-3,5$ & $-2,0$ & 0,7 \\
\hline 2016 & $\mathrm{R} \$ 2.661 .473 .992 .131$ & $R \$ 2.589 .501 .783 .428$ & $-3,5$ & $-2,5$ & 0,8 \\
\hline
\end{tabular}

Quadro Anexo 1: Indicadores econômicos nacionais. Ano referência de valores: 2016. Fonte: Sistema Integrado de Planejamento e Orçamento, Ministério do Planejamento, Desenvolvimento e Gestão do Governo Federal; Secretaria do Tesouro Nacional, Ministério da Fazenda do Governo Federal; Banco Central do Brasil; Instituto Brasileiro de Geografia e Estatística. Elaboração nossa 


\begin{tabular}{|c|c|c|c|c|c|c|c|c|c|c|c|c|c|c|c|c|c|}
\hline & 2000 & 2001 & 2002 & 2003 & 2004 & 2005 & 2006 & 2007 & 2008 & 2009 & 2010 & 2011 & 2012 & 2013 & 2014 & 2015 & 2016 \\
\hline ENERGIA ELÉTRICA & $\mathrm{R} \$ 241,13$ & $\mathrm{R} \$ 319,36$ & $\begin{array}{l}\text { R\$16.995,3 } \\
6\end{array}$ & $\mathrm{R} \$ 5.047,17$ & $\mathrm{R} \$ 315,97$ & $\mathrm{R} \$ 263,80$ & $\mathrm{R} \$ 225,20$ & $\mathrm{R} \$ 250,63$ & $\mathrm{R} \$ 257,20$ & $\mathrm{R} \$ 270,25$ & $\mathrm{R} \$ 258,03$ & $\mathrm{R} \$ 267,99$ & $\mathrm{R} \$ 69,27$ & $\mathrm{R} \$ 135,44$ & $\mathrm{R} \$ 256,79$ & $\mathrm{R} \$ 989,11$ & $\mathrm{R} \$ 852,07$ \\
\hline $\begin{array}{l}0272 \text { - Qualidade do Serviço de } \\
\text { Energia Elétrica }\end{array}$ & $R \$ 131,58$ & $R \$ 170,25$ & $\mathrm{R} \$ 123,83$ & $\mathrm{R} \$ 57,08$ & $R \$ 226,00$ & $\mathrm{R} \$ 216,01$ & $\mathrm{R} \$ 199,11$ & $\mathrm{R} \$ 221,18$ & $R \$ 237,55$ & $R \$ 257,91$ & $\mathrm{R} \$ 251,48$ & $\mathrm{R} \$ 266,73$ & RS- & RS- & $R \$-$ & RS- & RS- \\
\hline 0273 - Energia Cidadã & RS- & RS- & RS- & RS- & $\mathrm{R} \$ 81,52$ & RS- & RS- & RS- & RS- & RS- & RS- & RS- & RS- & RS- & R\$- & RS- & $R \$-$ \\
\hline $\begin{array}{l}0273 \text { - Energia das Pequenas } \\
\text { Comunidades }\end{array}$ & $\mathrm{R} \$ 50,41$ & $\mathrm{R} \$ 116,29$ & $R \$ 68,82$ & $R \$ 14,38$ & RS- & R\$- & RS- & RS- & RS- & RS- & RS- & RS- & RS- & RS- & RS- & RS- & RS- \\
\hline 0273 - Luz para Todos & RS- & RS- & R\$- & RS- & $R S-$ & $\mathrm{R} \$ 46,59$ & $R \$ 26,09$ & $R \$ 29,45$ & $\mathrm{R} \$ 19,64$ & $\mathrm{R} \$ 12,34$ & $R \$ 6,54$ & $R \$ 1,26$ & RS- & RS- & RS- & RS- & RS- \\
\hline $\begin{array}{l}0274 \text { - Abastecimento de Energia } \\
\text { Elétrica }\end{array}$ & $\mathrm{R} \$ 59,14$ & $\mathrm{R} \$ 32,83$ & $\begin{array}{l}\mathrm{R} \$ 16.802,7 \\
1\end{array}$ & $R \$ 4.975,71$ & $R \$ 8,46$ & $\mathrm{R} \$ 1,21$ & RS- & RŞ- & RŞ- & $\mathrm{RS}-$ & RS- & RS- & RS- & RS- & RS- & RS- & RS- \\
\hline 2033 - Energia Elétrica & $R \$-$ & $R \$-$ & RȘ- & $R \$-$ & RS- & $R \$-$ & $\mathrm{R} \$-$ & RS- & RS- & $R \$-$ & RS- & $R \$-$ & $\mathrm{R} \$ 69,27$ & $\mathrm{R} \$ 135,44$ & $\mathrm{R} \$ 256,79$ & $R \$ 989,11$ & $R \$ 852,07$ \\
\hline HABITAÇÃO & $\mathrm{R} \$ 1.160,49$ & $\mathrm{R} \$ 1.286,35$ & R\$1.248,49 & $\mathrm{R} \$ 1.235,65$ & $R \$ 1.459,48$ & $\mathrm{R} \$ 1.741,96$ & R\$2.379,18 & $R \$ 5.197,74$ & $R \$ 5.051,52$ & $\mathrm{R} \$ 5.605,29$ & $R \$ 3.523,62$ & $R \$ 3.078,95$ & $\begin{array}{l}\mathrm{R} \$ 16.797,2 \\
6\end{array}$ & $\begin{array}{l}\mathrm{R} \$ 19.654,0 \\
3\end{array}$ & $\begin{array}{l}\mathrm{R} \$ 19.956,5 \\
9\end{array}$ & $\begin{array}{l}\mathrm{R} \$ 18.063,3 \\
0\end{array}$ & R\$7.076,50 \\
\hline 0121 - Nosso Bairro & $R \$ 46,67$ & $R \$ 93,92$ & $R \$ 92,03$ & $\mathrm{R} \$ 259,14$ & $R \$-$ & RS- & RS- & RS- & $\mathrm{R} \$-$ & $R \$-$ & RS- & R\$- & RS- & $R \$-$ & RS- & R\$- & RS- \\
\hline 0128 - Morar Melhor & $\mathrm{R} \$ 1.093,27$ & $R \$ 1.170,57$ & $R \$ 304,00$ & $\mathrm{R} \$ 263,25$ & $\mathrm{R} \$ 82,36$ & RS- & RS- & RS- & RS- & RS- & RS- & RS- & RS- & RS- & RS- & RS- & $R \$-$ \\
\hline $\begin{array}{l}0778 \text { - Desenvvolvimento do } \\
\text { Mercado de Valores Mobiliários }\end{array}$ & $\mathrm{R} \$ 19,48$ & $\mathrm{R} \$ 15,91$ & $\mathrm{R} \$ 32,34$ & $\mathrm{R} \$ 90,68$ & $\mathrm{R} \$ 95,80$ & $\mathrm{R} \$ 111,54$ & $\mathrm{R} \$ 133,87$ & $\mathrm{R} \$ 158,22$ & $\mathrm{R} \$ 157,04$ & $\mathrm{R} \$ 178,81$ & $\mathrm{R} \$ 192,15$ & $\mathrm{R} \$ 181,27$ & RSS- & RȘ- & RS- & RSS- & RSS- \\
\hline $\begin{array}{l}0810 \text { - PBQP - Habitat - Programa } \\
\text { Brasileiro da Qualidade e } \\
\text { Produtividade do Habitat }\end{array}$ & RS- & RS- & RS- & RS- & RS- & RS- & RS- & RS- & RS- & RS- & RS- & RS- & RS- & RS- & RS- & RS- & $R \$-$ \\
\hline $\begin{array}{l}\text { O810 - Programa Brasileiro da } \\
\text { Qualidade e Produtividade do } \\
\text { Habitat - Pbqp-habitat }\end{array}$ & $\mathrm{R} \$ 1,08$ & $R \$ 5,95$ & RS- & $R \$-$ & $\mathrm{RS}-$ & R\$- & RS- & RS- & RS- & $R \$-$ & $R S-$ & RS- & $R S-$ & RS- & $R \$-$ & RS- & RS- \\
\hline $\begin{array}{l}\text { O810 - ualidade e } \\
\text { Produtividade do Habitat - PBQP-H }\end{array}$ & RS- & RS- & RS- & RS- & $\mathrm{R} \$ 1,01$ & $\mathrm{R} \$ 1,75$ & $\mathrm{R} \$ 0,68$ & $\mathrm{R} \$ 1,29$ & $\mathrm{R} \$ 0,09$ & $R \$ 0,64$ & $\mathrm{R} \$ 0,30$ & $\mathrm{R} \$ 0,00$ & $R \$-$ & RS- & $R \$-$ & RS- & RS- \\
\hline $\begin{array}{l}1128 \text { - Urbanização, } \\
\text { Regularização e Integração de } \\
\text { Assentamentos Precários }\end{array}$ & $\mathrm{R} \$-$ & $R \$-$ & RS- & $R \$-$ & $R \$ 560,08$ & $R \$-$ & $\mathrm{RS}-$ & RS- & RS- & $\mathrm{R} \$-$ & RS- & RS- & $R S-$ & $R \$-$ & $R \$-$ & $\mathrm{R} \$-$ & RS- \\
\hline $\begin{array}{l}1128 \text { Urbanização, } \\
\text { Regularização Fundária e } \\
\text { Integração de Assentamentos } \\
\text { Precários }\end{array}$ & RS- & $R \$-$ & RS- & $R \$-$ & $\mathrm{R} \$-$ & $R \$ 539,44$ & $\mathrm{R} \$ 1.742,11$ & $R \$ 3.364,38$ & $R \$ 3.713,56$ & $\mathrm{R} \$ 4.861,89$ & $\mathrm{R} \$ 3.193,49$ & $\mathrm{R} \$ 2.728,53$ & $\mathrm{R} \$-$ & R\$- & RS- & RS- & R\$- \\
\hline 2049 - Moradia Digna & RS- & RS- & RS- & RS- & $R \$-$ & RS- & RS- & RS- & RS- & RSS- & RS- & RŞ- & $\begin{array}{l}\mathrm{R} \$ 16.797,2 \\
6\end{array}$ & $\begin{array}{l}\mathrm{R} \$ 19.654,0 \\
3\end{array}$ & $\begin{array}{l}\mathrm{R} \$ 19.956,5 \\
9\end{array}$ & $\begin{array}{l}\mathrm{R} \$ 18.063,3 \\
0\end{array}$ & $R \$ 7.076,50$ \\
\hline 9991 - Carta de Crédito & R\$- & $\mathrm{R} \$-$ & $R \$ 820,12$ & $\mathrm{R} \$ 622,59$ & $\mathrm{RS}-$ & RS- & $\mathrm{RS}-$ & RS- & $\mathrm{R} \$-$ & RS- & $R \$-$ & $R \$-$ & R\$- & RS- & R\$- & RS- & $\mathrm{R} \$-$ \\
\hline $\begin{array}{l}9991 \text { - Habitação de Interesse } \\
\text { Social }\end{array}$ & RS\$- & RS- & R\$- & $\mathrm{R} \$-$ & $R \$ 720,22$ & $\mathrm{R} \$ 1.089,24$ & $R \$ 502,53$ & $R \$ 1.673,85$ & $R \$ 1.180,83$ & $R \$ 563,95$ & $R \$ 137,68$ & $\mathrm{R} \$ 169,14$ & RS- & RS- & RS- & RS- & RS- \\
\hline INFRAESTRUTURA URBANA & $\mathrm{R} \$ 645,94$ & $\mathrm{R} \$ 1.788,58$ & $\mathrm{R} \$ 1.675,58$ & $\mathrm{R} \$ 1.258,87$ & $\mathrm{R} \$ 585,54$ & R\$1.421,88 & $\mathrm{R} \$ 1.821,26$ & $\mathrm{R} \$ 2.097,70$ & $\mathrm{R} \$ 104,98$ & $\mathrm{R} \$ 58,76$ & $\mathrm{R} \$ 109,27$ & $\mathrm{R} \$ 66,87$ & RS- & RS- & RS- & RS- & RS- \\
\hline $\begin{array}{l}0312 \text { - Reestruturação de } \\
\text { Regiões Metropolitanas }\end{array}$ & $\mathrm{R} \$ 0,46$ & RS- & RS- & RS- & RS- & RS- & RS- & RS- & RS- & RȘ- & RS- & RS- & RS- & RSS- & RS- & RS- & RS- \\
\hline $\begin{array}{l}0803 \text { - Recursosos para o } \\
\text { Desenvolvimento }\end{array}$ & $\mathrm{R} \$ 125,40$ & $R \$ 542,15$ & $R \$ 593,73$ & $R \$ 767,55$ & $\mathrm{R} \$ 0,81$ & RS- & RS- & RS- & RS- & RS- & RS- & RS- & RS- & RS- & RS- & RS- & R\$- \\
\hline 0805 - Infra-estrutura Urbana & $\mathrm{R} \$ 510,29$ & $R \$ 1.208,23$ & R\$1.052,93 & $R \$ 460,06$ & RS- & RS- & RS- & RS- & RS- & RS- & RS- & RS\$- & RS- & RS- & RS- & RS\$- & RS- \\
\hline 0813 - Monumenta & RS- & RS- & RS- & RS- & $\mathrm{R} \$ 45,48$ & $R \$ 76,06$ & $R \$ 103,28$ & $\mathrm{R} \$ 122,26$ & $R \$ 71,21$ & $R \$ 56,53$ & $\mathrm{R} \$ 108,85$ & $R \$ 65,43$ & RS- & RS- & RS- & RS- & RS- \\
\hline $\begin{array}{l}0813 \text { - Monumenta - } \\
\text { Preservação do Patrimônio } \\
\text { Histórico }\end{array}$ & $\mathrm{R} \$ 9,80$ & RSS- & RSS- & RȘ- & RS- & RS- & RS- & RS- & RS- & RSS- & RS- & RS- & RS- & RSS- & RSS- & RSS- & RSS- \\
\hline $\begin{array}{l}\text { O813 - MONUMENTA: } \\
\text { PRESERVAÇÃO DO PATRIMÔNIO } \\
\text { HISTÓRICO }\end{array}$ & $R \$-$ & $\mathrm{R} \$ 38,20$ & $R \$ 28,92$ & $\mathrm{R} \$ 31,26$ & $R \$-$ & RS- & RS- & RS- & RS- & RS- & RS- & RS- & RS- & RS- & RS- & RS- & RS- \\
\hline $\begin{array}{l}1137 \text { - Reabilitação de Áreas } \\
\text { Urbanas Centrais }\end{array}$ & RS- & RS- & RS- & RS- & $R \$ 46,14$ & $\mathrm{R} \$ 21,77$ & $R \$ 22,51$ & $\mathrm{R} \$ 23,37$ & $R \$ 21,79$ & $R \$ 2,23$ & $R \$ 0,42$ & $\mathrm{R} \$ 1,43$ & RS- & RS- & RS- & RS- & $R \$-$ \\
\hline $\begin{array}{l}6001 \text { - Apoio ao } \\
\text { Desenvolvimento Urbano de } \\
\text { Municííios }\end{array}$ & RS- & RS- & RS- & RS- & RS- & RS- & RS- & RS- & $\mathrm{R} \$ 11,98$ & RS- & RS- & RS- & RS- & RS- & RS- & RS- & RS- \\
\hline $\begin{array}{l}6001 \text { - Apoio ao } \\
\text { Desenvolvimento Urbano de } \\
\text { Municíios de Pequeno Porte }\end{array}$ & $R \$-$ & RS- & $R \$-$ & RS- & $R \$ 340,57$ & $R \$ 998,91$ & $\mathrm{R} \$ 1.226,33$ & $\mathrm{R} \$ 1.404,59$ & RS- & RS- & RS- & RS- & RS- & RȘ- & RS- & $R \$-$ & RS- \\
\hline $\begin{array}{l}6002 \text { - Apoio ao } \\
\text { Desenvolvimento Urbano de }\end{array}$ & R\$- & R\$- & $R \$-$ & RS- & $\mathrm{R} \$ 152,54$ & $\mathrm{R} \$ 325,13$ & $R \$ 469,14$ & $R \$ 547,47$ & $\mathrm{R} \$-$ & $R \$-$ & $R \$-$ & R\$- & RS- & R\$- & RS- & $R \$-$ & $R \$-$ \\
\hline
\end{tabular}




\begin{tabular}{|c|c|c|c|c|c|c|c|c|c|c|c|c|c|c|c|c|c|}
\hline $\begin{array}{l}\text { Municípios de Médio e Grande } \\
\text { Porte }\end{array}$ & & & & & & & & & & & & & & & & & \\
\hline MOBILIDADE URBANA & $\mathrm{R} \$ 2.028,82$ & $\mathrm{R} \$ 1.861,36$ & $\mathrm{R} \$ 1.288,76$ & $\mathrm{R} \$ 815,15$ & $\mathrm{R} \$ 1.473,35$ & $\mathrm{R} \$ 2.026,63$ & $\mathrm{R} \$ 1.804,92$ & $\mathrm{R} \$ 2.632,22$ & $\mathrm{R} \$ 1.590,82$ & $\mathrm{R} \$ 1.709,23$ & $\mathrm{R} \$ 2.070,40$ & $\mathrm{R} \$ 1.723,97$ & $\mathrm{R} \$ 1.754,47$ & $\mathrm{R} \$ 1.075,37$ & $\mathrm{R} \$ 1.870,98$ & $\mathrm{R} \$ 1.268,40$ & R\$716,76 \\
\hline $\begin{array}{l}0222 \text { - Transporte Ferroviário } \\
\text { Urbano de Passageiros }\end{array}$ & $\mathrm{R} \$ 1.283,12$ & $R \$ 1.410,32$ & $\mathrm{R} \$ 794,20$ & $\mathrm{R} \$ 756,45$ & RȘ- & RSS- & RS- & RS- & RS- & RȘ- & RS- & RȘ- & RSS- & RȘ- & RS- & RS- & RS- \\
\hline 0222 - Trilhos Urbanos & RS- & RȘ- & RS- & RS- & $R \$ 0,24$ & RS- & RS- & RS- & RS- & R\$- & RS- & RS- & R\$- & R\$- & R\$- & RS- & RS- \\
\hline $\begin{array}{l}0231 \text { - Corredor } \\
\text { Transmetropolitano }\end{array}$ & $\mathrm{R} \$ 745,70$ & $\mathrm{R} \$ 451,04$ & $\mathrm{R} \$ 492,27$ & $R \$ 57,55$ & $\mathrm{R} \$ 205,24$ & $R \$ 208,38$ & $\mathrm{R} \$ 146,99$ & $R \$ 538,33$ & $R \$ 0,33$ & R\$- & $R \$-$ & R\$- & R\$- & RS- & R\$- & RS- & RS- \\
\hline 1078 - Nacional de Acessibilidade & RS\$- & RS- & RS- & RS- & $R \$ 1,73$ & $\mathrm{R} \$ 2,02$ & $\mathrm{R} \$ 2,70$ & $R \$ 2,93$ & $R \$ 14,38$ & $R \$ 6,04$ & $\mathrm{R} \$ 33,83$ & $R \$ 6,40$ & RS- & RS- & R\$- & RS- & RS- \\
\hline $\begin{array}{l}1295 \text { - Descentralização dos } \\
\text { Sistemas de Transporte Ferroviário } \\
\text { Urbano de Passageiros }\end{array}$ & RS- & RȘ- & RS- & RSS- & $\mathrm{R} \$ 1.091,57$ & $\mathrm{R} \$ 1.567,51$ & $\mathrm{R} \$ 1.385,37$ & $\mathrm{R} \$ 1.265,20$ & $\mathrm{R} \$ 1.383,13$ & $\mathrm{R} \$ 1.623,08$ & $\mathrm{R} \$ 1.919,65$ & $\mathrm{R} \$ 1.708,90$ & RSS- & RS - & RȘ- & RS- & RȘ- \\
\hline $\begin{array}{l}2048 \text { - Mobilidade Urbana e } \\
\text { Trânsito }\end{array}$ & RS- & RS- & RS- & RS- & RS- & RS- & RS- & RS- & RS- & RS- & RS- & RS- & $\mathrm{R} \$ 1.754,47$ & $\mathrm{R} \$ 1.075,37$ & $R \$ 1.870,98$ & $\mathrm{R} \$ 1.268,40$ & $\mathrm{R} \$ 716,76$ \\
\hline 9989 - Mobilidade Urbana & RS- & RS- & RS- & R\$- & $\mathrm{R} \$ 174,57$ & $\mathrm{R} \$ 248,72$ & $\mathrm{R} \$ 269,86$ & $R \$ 825,76$ & $\mathrm{R} \$ 192,98$ & $\mathrm{R} \$ 80,12$ & $\mathrm{R} \$ 116,91$ & $\mathrm{R} \$ 8,67$ & RS- & R\$- & RS- & R\$- & R\$- \\
\hline $\begin{array}{l}9989 \text { - Transporte Rodoviário } \\
\text { Urbano }\end{array}$ & RS- & RŞ- & $R \$ 2,29$ & $\mathrm{R} \$ 1,15$ & RȘ- & RS- & RS- & RȘ- & RȘ- & RȘ- & RS- & RȘ- & RŞ- & RS- & RŞ- & RS- & RŞ- \\
\hline OPERAÇÕES ESPECIAIS & $\mathrm{R} \$ 4.007,98$ & $\mathrm{R} \$ 583,47$ & $\mathrm{R} \$ 4.322,85$ & $\mathrm{R} \$ 1.751,95$ & $\mathrm{R} \$ 1.341,89$ & $\mathrm{R} \$ 1.069,13$ & R\$1.067,48 & $\begin{array}{l}\mathrm{R} \$ 10.116,4 \\
5\end{array}$ & $\mathrm{R} \$ 1.033,20$ & $\begin{array}{l}\mathrm{R} \$ 10.524,2 \\
2\end{array}$ & $\begin{array}{l}\mathrm{R} \$ 14.368,9 \\
9\end{array}$ & $\begin{array}{l}\mathrm{R} \$ 18.049,6 \\
4\end{array}$ & $R \$ 789,34$ & $\mathrm{R} \$ 1.234,38$ & $\begin{array}{l}\mathrm{R} \$ 14.666,8 \\
1\end{array}$ & $\mathrm{R} \$ 1.121,26$ & $\mathrm{R} \$ 839,12$ \\
\hline $\begin{array}{l}\text { O904 - Operaçōes Especiais: } \\
\text { Outras Transferênncias }\end{array}$ & $\mathrm{R} \$ 104,11$ & $\mathrm{R} \$ 111,38$ & RS- & RS- & R\$- & RS- & R\$- & RS- & RS- & RS- & RS- & RS- & RS- & RS- & RS- & R\$- & RS- \\
\hline $\begin{array}{l}\text { O909 - Operações Especiais: } \\
\text { Outros Encargos Especiais }\end{array}$ & $\mathrm{R} \$ 3.903,87$ & $R \$ 472,09$ & $\mathrm{R} \$ 4.322,85$ & $R \$ 1.751,95$ & $\mathrm{R} \$ 1.341,89$ & $\mathrm{R} \$ 1.069,13$ & $\mathrm{R} \$ 1.067,48$ & $\begin{array}{l}\mathrm{R} \$ 10.116,4 \\
5\end{array}$ & $\mathrm{R} \$ 1.033,20$ & $\begin{array}{l}\mathrm{R} \$ 10.524,2 \\
2\end{array}$ & $\begin{array}{l}\mathrm{R} \$ 14.368,9 \\
9\end{array}$ & $\begin{array}{l}\mathrm{R} \$ 18.049,6 \\
4\end{array}$ & $\mathrm{R} \$ 789,34$ & $\mathrm{R} \$ 1.234,38$ & $\begin{array}{l}\mathrm{R} \$ 14.666,8 \\
1\end{array}$ & $R \$ 1.121,26$ & $\mathrm{R} \$ 839,12$ \\
\hline $\begin{array}{l}0911 \text { - Operaçães Especiais - } \\
\text { Remuneração de Agentes } \\
\text { Financeiros }\end{array}$ & RS- & RS- & RS- & RS- & RS- & RS- & RS- & RS- & RS- & RS- & RS- & RS- & RS- & R\$- & RŞ- & RS- & RS- \\
\hline $\begin{array}{l}\text { PLANEJAMENTO E GESTÃO } \\
\text { PÚBLICA }\end{array}$ & $\mathrm{R} \$ 116,95$ & $\mathrm{R} \$ 101,82$ & $\mathrm{R} \$ 105,01$ & $\mathrm{R} \$ 76,42$ & $R \$ 190,92$ & $R \$ 320,09$ & $\mathrm{R} \$ 273,46$ & $\mathrm{R} \$ 1.467,40$ & $R \$ 3.022,28$ & $R \$ 2.688,75$ & R\$1.992,94 & R\$1.609,49 & $R \$ 2.588,30$ & R\$3.210,57 & $\mathrm{R} \$ 2.580,99$ & $R \$ 2.769,35$ & $R \$ 2.631,02$ \\
\hline $\begin{array}{l}0138 \text { - Gerenciamento da } \\
\text { Estrutura Fundiária }\end{array}$ & $\mathrm{R} \$ 54,11$ & $\mathrm{R} \$ 44,35$ & $\mathrm{R} \$ 51,21$ & $R \$ 35,53$ & RS- & RS- & RSS- & RS- & RS- & RŞ- & RS\$- & R\$- & RŞ- & RŞ- & RS- & RS\$- & RŞ- \\
\hline $\begin{array}{l}0138 \text { - Gerenciamento da } \\
\text { Estrutura Fundiária e Destinação de } \\
\text { Terras públicas }\end{array}$ & RS- & RS- & RŞ- & RS- & RS- & RS- & RS- & RS- & $\mathrm{R} \$ 157,94$ & $\mathrm{R} \$ 169,60$ & $\mathrm{R} \$ 262,48$ & $\mathrm{R} \$ 172,32$ & R\$- & RS- & RS- & RS- & RS- \\
\hline $\begin{array}{l}0138 \text { - Regularização e } \\
\text { Gerenciamento da Estrutura } \\
\text { Fundiária }\end{array}$ & R\$- & RS- & R\$- & RS- & $\mathrm{R} \$ 82,59$ & $\mathrm{R} \$ 123,10$ & $\mathrm{R} \$ 98,47$ & $\mathrm{R} \$ 128,93$ & R\$- & R\$- & R\$- & RS- & RS- & RȘ- & RS- & RŞ- & RȘ- \\
\hline $\begin{array}{l}0310 \text { - Gestão da Política de } \\
\text { Desenvolvimento Urbano }\end{array}$ & $\mathrm{R} \$ 4,69$ & $\mathrm{R} \$ 7,48$ & $\mathrm{R} \$ 12,29$ & $\mathrm{R} \$ 6,45$ & $\mathrm{R} \$ 23,87$ & $\mathrm{R} \$ 59,03$ & $\mathrm{R} \$ 104,81$ & $\mathrm{R} \$ 1.218,87$ & $R \$ 2.746,62$ & $\mathrm{R} \$ 2.402,76$ & $\mathrm{R} \$ 1.631,50$ & $\mathrm{R} \$ 1.229,81$ & RS- & R\$- & RS- & RS- & RS- \\
\hline 0311 - Gestão Urbana & $\mathrm{R} \$ 11,64$ & $R \$ 14,70$ & RS- & R\$- & RS- & RS- & RS- & RS- & RS- & R\$- & RS- & RS- & RS- & RS- & R\$- & RS- & RS- \\
\hline $\begin{array}{l}0311 \text { - Gestão Urbana e } \\
\text { Metropolitana }\end{array}$ & RS- & RȘ- & $R \$ 3,56$ & $\mathrm{R} \$ 1,27$ & RŞ- & $\mathrm{RS}-$ & RŞ- & RS- & RS- & RS- & RȘ- & R\$- & RS- & RS- & R\$- & RS - & R\$- \\
\hline $\begin{array}{l}0794 \text { - Gestão do Patrimônio } \\
\text { Imobiliário da União }\end{array}$ & RS- & RS- & RSS- & RS- & $\mathrm{R} \$ 40,48$ & $\mathrm{R} \$ 49,25$ & $\mathrm{R} \$ 45,74$ & $\mathrm{R} \$ 54,17$ & $R \$ 59,37$ & $R \$ 78,64$ & $R \$ 73,81$ & $\mathrm{R} \$ 52,69$ & RȘ- & RȘ- & R\$- & RŞ- & RSS- \\
\hline $\begin{array}{l}0794 \text { - Gestão do Patrimônio } \\
\text { Público }\end{array}$ & $\mathrm{R} \$ 46,49$ & $\mathrm{R} \$ 35,29$ & $\mathrm{R} \$ 37,95$ & $\mathrm{R} \$ 33,17$ & RS- & RS- & RS- & RS- & RS- & RŞ- & RS- & RS- & RS- & RS- & RS- & RS - & RS- \\
\hline $\begin{array}{l}1136 \text { - Fortalecimento da Gestão } \\
\text { Municipal Urbana }\end{array}$ & RS- & RS- & R\$- & RS- & $\mathrm{R} \$ 43,98$ & RS- & RS- & RS- & RS- & R\$- & R\$- & R\$- & R\$- & R\$- & R\$- & RS- & RSS- \\
\hline $\begin{array}{l}1136 \text { - Fortalecimento da Gestão } \\
\text { Urbana }\end{array}$ & RS- & RS- & RS- & RS- & RS- & $\mathrm{R} \$ 88,71$ & $\mathrm{R} \$ 24,45$ & $\mathrm{R} \$ 65,42$ & $\mathrm{R} \$ 58,36$ & $\mathrm{R} \$ 37,74$ & $\mathrm{R} \$ 25,15$ & $\mathrm{R} \$ 154,67$ & RS- & RS- & RS- & RS- & RSS- \\
\hline 2054 - Planejamento Urbano & RȘ- & RS- & RȘ- & RS- & RSS- & RȘ- & RŞ- & RȘ- & RS- & RȘ- & RS- & RS\$- & $R \$ 1.490,13$ & $\mathrm{R} \$ 2.020,35$ & $\mathrm{R} \$ 1.467,92$ & $\mathrm{R} \$ 1.604,22$ & $R \$ 1.486,52$ \\
\hline $\begin{array}{l}2116 \text { - Programa de Gestão e } \\
\text { Manutenção do Ministerio das } \\
\text { Cidades }\end{array}$ & RS- & RS- & RS - & RS- & RS- & RS - & RSS- & RS - & RS- & RS- & RS- & RS- & $\mathrm{R} \$ 1.098,17$ & $\mathrm{R} \$ 1.190,23$ & $\mathrm{R} \$ 1.113,07$ & $\mathrm{R} \$ 1.165,14$ & $R \$ 1.144,49$ \\
\hline SANEAMENTO BÁSICO & $\mathrm{R} \$ 2.487,14$ & $\mathrm{R} \$ 6.792,60$ & $\mathrm{R} \$ 2.999,76$ & $\mathrm{R} \$ 1.057,23$ & $R \$ 1.665,59$ & $\mathrm{R} \$ 2.430,27$ & $\mathrm{R} \$ 2.435,67$ & $\mathrm{R} \$ 6.081,12$ & $R \$ 5.320,09$ & R\$5.730,94 & $R \$ 4.608,93$ & $\mathrm{R} \$ 4.945,44$ & $R \$ 4.043,54$ & $\mathrm{R} \$ 3.942,27$ & $R \$ 2.207,23$ & $R \$ 1.394,78$ & $\mathrm{R} \$ 1.266,79$ \\
\hline 0119 - Saneamento Básico & $\mathrm{R} \$ 682,69$ & $\mathrm{R} \$ 3.616,96$ & $R \$ 1.553,62$ & $\mathrm{R} \$ 414,33$ & RS- & RS- & RȘ- & RS- & RS- & R\$- & RS- & R\$- & RS- & RS- & R\$- & R\$- & R\$- \\
\hline $\begin{array}{l}0122 \text { - Saneamento Ambiental } \\
\text { Urbano }\end{array}$ & RȘ- & RȘ- & RȘ- & RȘ- & $\mathrm{R} \$ 1.126,80$ & $R \$ 1.366,04$ & RŞ- & RȘ- & RȘ- & RȘ- & RS- & RȘ- & RS- & RŞ- & RŞ- & RŞ- & RS- \\
\hline 0122 - Saneamento É Vida & $\mathrm{R} \$ 7,74$ & RS- & $R \$ 207,27$ & $\mathrm{R} \$ 120,98$ & RS- & RS- & RSS- & RS- & $\mathrm{R} \$-$ & RSS- & RS- & R\$- & R\$- & RS- & $R \$-$ & RS- & RS- \\
\hline $\begin{array}{l}0122 \text { - Serviços Urbanos de Água } \\
\text { e Esgoto }\end{array}$ & R\$- & R\$- & $R \$-$ & R\$- & RS- & RȘ- & $R \$ 1.717,71$ & $\mathrm{R} \$ 3.801,22$ & $\mathrm{R} \$ 3.061,05$ & $R \$ 3.473,59$ & $R \$ 2.500,12$ & $R \$ 3.355,26$ & $R S-$ & RŞ- & RȘ- & RSS- & RŞ- \\
\hline 0495 - Proágua - Gestão & $R \$ 152,58$ & $\mathrm{R} \$ 290,60$ & $\mathrm{R} \$ 47,72$ & $\mathrm{R} \$ 23,97$ & RS- & RS- & RS- & RS- & RS- & RS- & R\$- & RS- & RS- & RS- & RS- & R\$- & R\$- \\
\hline 0515 - Infra-Estrutura Hídrica & RȘ- & RȘ- & RȘ- & Rș- & RSS- & R\$- & RS\$- & RȘ- & $\mathrm{R} \$ 1.853,04$ & $\mathrm{R} \$ 1.059,43$ & $R \$ 995,84$ & $R \$ 641,85$ & 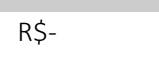 & RȘ- & $\mathrm{RS}-$ & RȘ- & RȘ- \\
\hline
\end{tabular}




\begin{tabular}{|c|c|c|c|c|c|c|c|c|c|c|c|c|c|c|c|c|c|}
\hline 0515 - Proágua - Infra-estrutura & R\$1.601,10 & R\$- & R\$- & RS- & RS- & R\$- & RS- & R\$- & RS- & RS- & R\$- & R\$- & RS- & R\$- & R\$- & R\$- & R\$- \\
\hline $\begin{array}{l}0515 \text { - PROÁGUA INFRA- } \\
\text { ESTRUTURA }\end{array}$ & RS- & $R \$ 2.746,56$ & $\mathrm{R} \$ 1.096,03$ & $\mathrm{R} \$ 487,75$ & $R \$ 339,60$ & $R \$ 666,00$ & $\mathrm{R} \$ 354,39$ & $\mathrm{R} \$ 1.818,56$ & RS\$- & RȘ- & RS- & RȘ- & RȘ- & $\mathrm{RS}-$ & RS- & RS'- & $\mathrm{RS}-$ \\
\hline 0516 - Brasil Joga Limpo & $R \$ 43,04$ & $\mathrm{R} \$ 138,48$ & $R \$ 74,98$ & $\mathrm{R} \$ 4,82$ & RS- & RS- & RS- & RS- & RS- & RS- & RS- & RS- & RS- & RSS- & RS- & RŞ- & RŞ- \\
\hline 0516 - Viver Sem Contaminação & $\mathrm{R} \$-$ & $R S$ & RȘ- & RS- & $R \$ 6,71$ & $\mathrm{R} \$ 4,84$ & RS- & RŞ- & RS- & $R S-$ & RS- & $R \$-$ & $R \$-$ & RS- & R\$- & $R \$-$ & $R \$-$ \\
\hline $\begin{array}{l}1138 \text { - Drenagem Urbana e } \\
\text { Controle de Erosão Marítima e } \\
\text { Fluvial }\end{array}$ & RS\$- & RS- & RS- & RS- & RȘ- & RS- & $R \$-$ & RS- & $\mathrm{R} \$ 284,13$ & $\mathrm{R} \$ 911,50$ & $\mathrm{R} \$ 939,22$ & $\mathrm{R} \$ 610,16$ & $R \$-$ & $R \$-$ & $R \$-$ & $R \$-$ & $R \$-$ \\
\hline $\begin{array}{l}1138 \text { - Drenagem Urbana } \\
\text { Sustentável }\end{array}$ & $R \$-$ & RS- & RS- & RS- & $\mathrm{R} \$ 96,41$ & $\mathrm{R} \$ 275,37$ & $\mathrm{R} \$ 263,10$ & $R \$ 372,82$ & RS- & RS- & RS- & RŞ- & RS- & RS- & RS- & RS- & RS- \\
\hline 2067 - Resíduos Sólidos & R\$- & RS- & RS- & RS- & RS- & RS- & RS- & $\mathrm{R} \$-$ & RS- & RS- & RS- & RS- & $\mathrm{R} \$ 102,69$ & $R \$ 92,65$ & $\mathrm{R} \$ 88,95$ & $\mathrm{R} \$ 20,88$ & RS- \\
\hline 2068 - Saneamento Básico & RS- & RS- & RS- & RS- & RSS- & RSS- & RS- & RSS- & RS- & RS- & RS- & RSS- & $R \$ 3.940,85$ & $R \$ 3.849,62$ & $\mathrm{R} \$ 2.118,28$ & $\mathrm{R} \$ 1.373,90$ & $\mathrm{R} \$ 1.266,79$ \\
\hline $\begin{array}{l}8007 \text { - Gestão de Resíduos } \\
\text { Sólidos Urbanos }\end{array}$ & RS- & RS- & $\mathrm{R} \$ 20,14$ & $R \$ 5,38$ & RS- & RS- & RS- & RS- & RS- & RS- & RS- & RS- & RS- & RS- & RS- & RS- & RS- \\
\hline 8007 - Residuos Sólidos Urbanos & $R \$-$ & $R \$-$ & R\$- & RS- & $R \$ 96,07$ & $\mathrm{R} \$ 118,04$ & $\mathrm{R} \$ 100,47$ & $R \$ 88,52$ & $\mathrm{R} \$ 121,87$ & $\mathrm{R} \$ 286,43$ & $\mathrm{R} \$ 173,74$ & $\mathrm{R} \$ 338,16$ & RS- & RS- & $R \$-$ & RS- & RS- \\
\hline
\end{tabular}

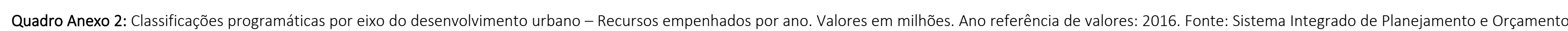
Ministério do Planejamento, Desenvolvimento e Gestão do Governo Federal. Elaboração nossa. 


\begin{tabular}{|c|c|c|c|c|c|c|c|c|c|c|c|c|c|c|c|c|c|}
\hline & 2000 & 2001 & 2002 & 2003 & 2004 & 2005 & 2006 & 2007 & 2008 & 2009 & 2010 & 2011 & 2012 & 2013 & 2014 & 2015 & 2016 \\
\hline ENERGIA ELÉTRICA & $\mathrm{R} \$ 241,13$ & $\mathrm{R} \$ 319,36$ & $\begin{array}{l}\text { R\$16.995,3 } \\
6\end{array}$ & R\$5.047,17 & $\mathrm{R} \$ 315,97$ & $R \$ 263,80$ & $\mathrm{R} \$ 225,20$ & $R \$ 224,73$ & $\mathrm{R} \$ 217,89$ & $R \$ 235,05$ & $R \$ 235,12$ & $R \$ 246,65$ & $\mathrm{R} \$ 48,21$ & $\mathrm{R} \$ 121,56$ & $\mathrm{R} \$ 232,16$ & $R \$ 833,35$ & $R \$ 818,23$ \\
\hline $\begin{array}{l}0272 \text { - Qualidade do Serviço de } \\
\text { Energia Elétrica }\end{array}$ & $\mathrm{R} \$ 131,58$ & $R \$ 170,25$ & $\mathrm{R} \$ 123,83$ & $R \$ 57,08$ & $R \$ 226,00$ & $\mathrm{R} \$ 216,01$ & $\mathrm{R} \$ 199,11$ & $\mathrm{R} \$ 200,39$ & $R \$ 204,34$ & $R \$ 226,93$ & $\mathrm{R} \$ 231,28$ & $R \$ 246,30$ & RS- & RS- & RS- & RS- & RS- \\
\hline 0273 - Energia Cidadã & R\$- & RS- & RS- & RS- & $\mathrm{R} \$ 81,52$ & RS- & RS- & RS- & RS- & RS- & RS- & RS- & RS- & RS- & RS- & $R \$-$ & RS- \\
\hline $\begin{array}{l}0273 \text { - Energia das Pequenas } \\
\text { Comunidades }\end{array}$ & $\mathrm{R} \$ 50,41$ & $R \$ 116,29$ & $\mathrm{R} \$ 68,82$ & $R \$ 14,38$ & RS- & RS- & RS- & RS- & RS- & R\$- & RS- & RS- & RS- & RS- & RS- & RS- & RS- \\
\hline 0273 - Luz para Todos & RS- & RS- & RS- & RS- & RS- & $\mathrm{R} \$ 46,59$ & $R \$ 26,09$ & $R \$ 24,33$ & $R \$ 13,55$ & $R \$ 8,13$ & $R \$ 3,84$ & $R \$ 0,35$ & RS- & RS- & RS- & R\$- & RS- \\
\hline $\begin{array}{l}0274 \text { - Abastecimento de Energia } \\
\text { Elétrica }\end{array}$ & $\mathrm{R} \$ 59,14$ & $\mathrm{R} \$ 32,83$ & $\begin{array}{l}\mathrm{R} \$ 16.802,7 \\
1\end{array}$ & $R \$ 4.975,71$ & $R \$ 8,46$ & $R \$ 1,21$ & RS'- & RS- & RS- & RS- & RS- & R\$- & RS- & RS- & RS- & RS- & RS- \\
\hline 2033 - Energia Elétrica & RS- & $R \$-$ & RS- & $R \$-$ & $\mathrm{R} \$-$ & RS- & $R \$-$ & RS- & $\mathrm{RS}-$ & $R \$-$ & RS- & $R \$-$ & $R \$ 48,21$ & $\mathrm{R} \$ 121,56$ & $\mathrm{R} \$ 232,16$ & $R \$ 833,35$ & $R \$ 818,23$ \\
\hline HABITAÇÃO & R\$1.160,49 & $\mathrm{R} \$ 1.286,35$ & R\$1.248,49 & R\$1.235,65 & $\mathrm{R} \$ 1.459,48$ & R\$1.741,96 & R\$2.379,18 & $R \$ 1.185,42$ & $\mathrm{R} \$ 1.583,00$ & $\mathrm{R} \$ 2.197,54$ & R\$1.447,84 & $\mathrm{R} \$ 401,75$ & $R \$ 3.640,58$ & $\mathrm{R} \$ 8.442,43$ & $\begin{array}{l}\mathrm{R} \$ 13.259,6 \\
4\end{array}$ & $\begin{array}{l}\mathrm{R} \$ 16.526,0 \\
3\end{array}$ & $\mathrm{R} \$ 6.757,51$ \\
\hline 0121 - Nosso Bairro & $R \$ 46,67$ & $R \$ 93,92$ & $R \$ 92,03$ & $\mathrm{R} \$ 259,14$ & $R \$-$ & RS- & $R \$-$ & $R \$-$ & $R \$-$ & R\$- & $R \$-$ & $R \$-$ & $R \$-$ & RS- & R\$- & R\$- & RS- \\
\hline 0128 - Morar Melhor & $R \$ 1.093,27$ & $R \$ 1.170,57$ & $\mathrm{R} \$ 304,00$ & $\mathrm{R} \$ 263,25$ & $\mathrm{R} \$ 82,36$ & RS- & RS- & RS- & RS- & RS- & RS- & $R \$-$ & RS- & RS- & RS- & RS - & RS- \\
\hline $\begin{array}{l}0778 \text { - Desenvvolvimento do } \\
\text { Mercado de Valores Mobiliários }\end{array}$ & $\mathrm{R} \$ 19,48$ & $\mathrm{R} \$ 15,91$ & $\mathrm{R} \$ 32,34$ & $\mathrm{R} \$ 90,68$ & $\mathrm{R} \$ 95,80$ & $\mathrm{R} \$ 111,54$ & $\mathrm{R} \$ 133,87$ & $\mathrm{R} \$ 138,19$ & $\mathrm{R} \$ 142,55$ & $\mathrm{R} \$ 158,90$ & $\mathrm{R} \$ 180,61$ & $\mathrm{R} \$ 167,57$ & RȘ- & RS- & RSS- & RȘ- & RS- \\
\hline $\begin{array}{l}0810 \text { - PBQP - Habitat - Programa } \\
\text { Brasaliero da Qualidade e } \\
\text { Produtuividade do tabitat }\end{array}$ & RS- & $R \$-$ & $\mathrm{R} \$-$ & RS- & R\$- & RS- & R\$- & $R \$-$ & R\$- & RS- & RS- & R\$- & $R \$-$ & RS- & $\mathrm{R} \$-$ & RS- & RS- \\
\hline $\begin{array}{l}\text { O810 - Programa Brasileiro da } \\
\text { Qualidade e Produtividade do } \\
\text { Habitat - Pbqp-habitat }\end{array}$ & $R \$ 1,08$ & $R \$ 5,95$ & $R \$-$ & RS- & $\mathrm{R} \$-$ & $R S-$ & RS- & RS- & $\mathrm{RS}-$ & RS- & RS- & R\$- & RS- & R\$- & RS- & $R \$-$ & RS- \\
\hline $\begin{array}{l}\text { O810 - ualidade e } \\
\text { Produtividade do Habitat - PBQP-H }\end{array}$ & RS- & RS- & RS- & RS- & $\mathrm{R} \$ 1,01$ & $\mathrm{R} \$ 1,75$ & $\mathrm{R} \$ 0,68$ & $\mathrm{R} \$ 0,47$ & $\mathrm{R} \$ 0,09$ & $\mathrm{R} \$ 0,62$ & $\mathrm{R} \$ 0,30$ & $R \$ 0,00$ & $R \$-$ & RS- & RS- & RS- & RS- \\
\hline $\begin{array}{l}1128 \text { - Urbanização, } \\
\text { Regularização e Integração de } \\
\text { Assentamentos Precários }\end{array}$ & RS- & $R \$-$ & $R \$-$ & $R \$-$ & $R \$ 560,08$ & RS- & RS- & $R \$-$ & $\mathrm{R} \$-$ & RS- & RS- & $R \$-$ & RS- & R\$- & RS- & RS- & RS- \\
\hline $\begin{array}{l}1128 \text { Urbanização, } \\
\text { Regularização Fundária e } \\
\text { Integração de Assentamentos } \\
\text { Precários }\end{array}$ & RS- & $R \$-$ & $\mathrm{R} \$-$ & RS- & RS- & $R \$ 539,44$ & $\mathrm{R} \$ 1.742,11$ & $\mathrm{R} \$ 165,68$ & $\mathrm{R} \$ 1.257,46$ & $R \$ 1.963,29$ & $R \$ 1.244,43$ & $R \$ 216,38$ & $R \$-$ & RS- & RS- & RS- & $R \$-$ \\
\hline 2049 - Moradia Digna & RS- & RS- & RS- & RS- & RS- & RS- & RS- & RS- & RS- & RS\$- & RS- & RS- & $R \$ 3.640,58$ & $R \$ 8.442,43$ & $\begin{array}{l}\mathrm{R} \$ 13.259,6 \\
4\end{array}$ & $\begin{array}{l}\mathrm{R} \$ 16.526,0 \\
3\end{array}$ & $R \$ 6.757,51$ \\
\hline 9991 - Carta de Crédito & RS- & $\mathrm{R} \$-$ & $\mathrm{R} \$ 820,12$ & $\mathrm{R} \$ 622,59$ & $R \$-$ & RS- & RS- & RS- & $\mathrm{RS}-$ & $R \$-$ & RS- & RSS- & RS- & RS- & R\$- & RS- & $\mathrm{R} \$-$ \\
\hline $\begin{array}{l}9991 \text { - Habitação de Interesse } \\
\text { Social }\end{array}$ & RSS- & RS- & R\$- & R\$̦- & $R \$ 720,22$ & $\mathrm{R} \$ 1.089,24$ & $R \$ 502,53$ & $\mathrm{R} \$ 881,08$ & $\mathrm{R} \$ 182,90$ & $R \$ 74,74$ & $R \$ 22,50$ & $R \$ 17,79$ & RS\$- & RS- & RS- & RS- & RS- \\
\hline INFRAESTRUTURA URBANA & $\mathrm{R} \$ 645,94$ & $\mathrm{R} \$ 1.788,58$ & R\$1.675,58 & $\mathrm{R} \$ 1.258,66$ & $\mathrm{R} \$ 585,54$ & R\$1.421,88 & $\mathrm{R} \$ 1.821,26$ & $\mathrm{R} \$ 61,21$ & $R \$ 26,53$ & $\mathrm{R} \$ 12,02$ & $R \$ 24,90$ & $\mathrm{R} \$ 13,96$ & RS- & RSS- & RS- & RS- & RS- \\
\hline $\begin{array}{l}0312 \text { - Reestruturação de } \\
\text { Regiões Metropolitanas }\end{array}$ & $\mathrm{R} \$ 0,46$ & RS- & RS- & RS- & RS- & RS- & RS- & RS- & RŞ- & RS- & RS- & RS- & RS - & RŞ- & RS- & RS- & RS- \\
\hline $\begin{array}{l}0803 \text { - Recursos para o } \\
\text { Desenvolvimento }\end{array}$ & $\mathrm{R} \$ 125,40$ & $R \$ 542,15$ & $R \$ 593,73$ & $\mathrm{R} \$ 767,55$ & $\mathrm{R} \$ 0,81$ & RS- & RS- & RS - & RS- & RS- & RS- & RS- & RS- & RS- & RS- & RS- & RS- \\
\hline 0805 - Infra-estrutura Urbana & $R \$ 510,29$ & $\mathrm{R} \$ 1.208,23$ & $\mathrm{R} \$ 1.052,93$ & $R \$ 460,06$ & R\$- & $R \$-$ & $R \$-$ & RS- & RS- & RS- & $R \$-$ & RS- & $R \$-$ & $\mathrm{RS}-$ & $R \$-$ & $R \$-$ & $R \$-$ \\
\hline 0813 - Monumenta & R\$- & RS- & RS- & RS- & $\mathrm{R} \$ 45,48$ & $\mathrm{R} \$ 76,06$ & $\mathrm{R} \$ 103,28$ & $\mathrm{R} \$ 49,74$ & $R \$ 24,24$ & $\mathrm{R} \$ 11,70$ & $\mathrm{R} \$ 24,48$ & $\mathrm{R} \$ 13,57$ & RS- & RS- & RS- & RS- & RS- \\
\hline $\begin{array}{l}0813 \text { - Monumenta - } \\
\text { Preservação do Patrimônio } \\
\text { Histórico }\end{array}$ & $\mathrm{R} \$ 9,80$ & RSS- & RȘ- & RS- & RSS- & RȘ- & RS- & RS- & RȘ- & RSS- & RSS- & RSS- & RSS- & RSS- & RS- & RȘ- & RS- \\
\hline $\begin{array}{l}\text { O813 - MONUMENTA: } \\
\text { PRESERVAÇÃO DO PATRIMÔNIO } \\
\text { HISTÓRICO }\end{array}$ & RS- & $\mathrm{R} \$ 38,20$ & $\mathrm{R} \$ 28,92$ & $\mathrm{R} \$ 31,04$ & RS- & RS- & RS- & $R \$-$ & RS- & RS- & RS- & RS- & RS- & RS- & RS- & RS- & RS- \\
\hline $\begin{array}{l}1137 \text { - Reabilitação de Áreas } \\
\text { Urbanas Centrais }\end{array}$ & RS- & RS- & RS- & RS- & $R \$ 46,14$ & $\mathrm{R} \$ 21,77$ & $\mathrm{R} \$ 22,51$ & RS- & $\mathrm{R} \$ 0,49$ & $\mathrm{R} \$ 0,32$ & $\mathrm{R} \$ 0,42$ & $\mathrm{R} \$ 0,40$ & RS- & RS- & RS- & RS- & RS- \\
\hline $\begin{array}{l}6001 \text { - Apoio ao } \\
\text { Desenvolvimento Urbano de } \\
\text { Muncíios }\end{array}$ & RS- & RS- & RS- & RS- & RS- & RS- & RS- & RS- & $\mathrm{R} \$ 1,80$ & RS- & RS- & RS- & RS- & RS- & RS- & RSS- & RS- \\
\hline $\begin{array}{l}6001 \text { - Apoio ao } \\
\text { Desenvolvimento Urbano de } \\
\text { Municíios de Pequeno Porte }\end{array}$ & RS- & RS- & RS- & RS- & $R \$ 340,57$ & $R \$ 998,91$ & $\mathrm{R} \$ 1.226,33$ & $R \$ 9,13$ & RS- & RS- & $R \$-$ & RS- & $R \$-$ & RS- & RSS- & RS- & RS- \\
\hline $\begin{array}{l}6002 \text { - Apoio ao } \\
\text { Desenvolvimento Urbano de }\end{array}$ & RS- & R\$- & $R \$-$ & $R \$-$ & $\mathrm{R} \$ 152,54$ & $\mathrm{R} \$ 325,13$ & $R \$ 469,14$ & $\mathrm{R} \$ 2,34$ & $\mathrm{RS}-$ & RS- & RS- & RS- & $R \$-$ & RS- & $R \$-$ & R\$- & $R \$-$ \\
\hline
\end{tabular}




\begin{tabular}{|c|c|c|c|c|c|c|c|c|c|c|c|c|c|c|c|c|c|}
\hline \multicolumn{18}{|l|}{$\begin{array}{l}\text { Municípios de Médio e Grande } \\
\text { Porte }\end{array}$} \\
\hline MOBILIDADE URBANA & $\mathrm{R} \$ 2.028,82$ & $\mathrm{R} \$ 1.861,36$ & $\mathrm{R} \$ 1.288,76$ & $\mathrm{R} \$ 815,14$ & $\mathrm{R} \$ 1.473,35$ & R\$2.026,63 & $\mathrm{R} \$ 1.804,92$ & R\$1.453,20 & $\mathrm{R} \$ 755,59$ & $\mathrm{R} \$ 1.031,61$ & $\mathrm{R} \$ 1.439,59$ & $\mathrm{R} \$ 1.363,76$ & $\mathrm{R} \$ 418,55$ & $\mathrm{R} \$ 358,15$ & $\mathrm{R} \$ 714,42$ & $\mathrm{R} \$ 163,90$ & $\mathrm{R} \$ 395,56$ \\
\hline $\begin{array}{l}0222 \text { - Transporte Ferroviário } \\
\text { Urbano de Passageiros }\end{array}$ & $\mathrm{R} \$ 1.283,12$ & R\$1.410,32 & $\mathrm{R} \$ 794,20$ & $\mathrm{R} \$ 756,44$ & RS- & RS- & RS- & RS- & RS- & RS- & RS- & RS- & RS- & RS- & RS- & RS- & $R \$-$ \\
\hline 0222 - Trilhos Urbanos & RS- & RS- & R\$- & RS- & $R \$ 0,24$ & R\$- & RS- & RS- & $R \$-$ & RS- & $R \$-$ & RS- & RS- & RS- & RS- & RS- & $\mathrm{R} \$-$ \\
\hline $\begin{array}{l}0231 \text { - Corredor } \\
\text { Transmetropolitano }\end{array}$ & $\mathrm{R} \$ 745,70$ & $\mathrm{R} \$ 451,04$ & $\mathrm{R} \$ 492,27$ & $R \$ 57,55$ & $\mathrm{R} \$ 205,24$ & $\mathrm{R} \$ 208,38$ & $\mathrm{R} \$ 146,99$ & $\mathrm{R} \$ 459,53$ & $\mathrm{R} \$ 0,17$ & RSS- & RS- & RS- & RȘ- & RS- & RS- & RȘ- & RS- \\
\hline 1078 - Nacional de Acessibilidade & RSS- & $\mathrm{RS}-$ & RS- & RS- & $\mathrm{R} \$ 1,73$ & $R \$ 2,02$ & $R \$ 2,70$ & $R \$ 2,55$ & $R \$ 6,98$ & $\mathrm{R} \$ 1,59$ & $R \$ 3,72$ & $\mathrm{R} \$ 2,31$ & RS- & RS- & RS- & $R \$-$ & RS- \\
\hline $\begin{array}{l}1295 \text { - Descentralização dos } \\
\text { Sistemas de Transporte Ferroviário } \\
\text { Urbano de Passageiros }\end{array}$ & RS- & RS- & RS- & RS- & $\mathrm{R} \$ 1.091,57$ & R\$1.567,51 & $\mathrm{R} \$ 1.385,37$ & $\mathrm{R} \$ 936,72$ & $R \$ 748,02$ & R\$1.029,07 & $\mathrm{R} \$ 1.435,00$ & $\mathrm{R} \$ 1.361,24$ & RS- & RS- & RS- & RS - & RS- \\
\hline $\begin{array}{l}2048 \text { - Mobilidade Urbana e } \\
\text { Trânsito }\end{array}$ & RS- & RS- & RS- & RS- & $R \$-$ & RS- & $R \$-$ & $R \$-$ & $R \$-$ & $\mathrm{R} \$-$ & $R \$-$ & RS- & $\mathrm{R} \$ 418,55$ & $\mathrm{R} \$ 358,15$ & $R \$ 714,42$ & $\mathrm{R} \$ 163,90$ & $\mathrm{R} \$ 395,56$ \\
\hline 9989 - Mobilidade Urbana & RS- & RS- & RS- & RS- & $\mathrm{R} \$ 174,57$ & $R \$ 248,72$ & $\mathrm{R} \$ 269,86$ & $\mathrm{R} \$ 54,41$ & $\mathrm{R} \$ 0,41$ & $\mathrm{R} \$ 0,95$ & $\mathrm{R} \$ 0,87$ & $\mathrm{R} \$ 0,21$ & RS- & RS- & RS- & RS- & RS- \\
\hline $\begin{array}{l}9989 \text { - Transporte Rodoviário } \\
\text { Urbano }\end{array}$ & $R \$-$ & $\mathrm{R} \$-$ & $R \$ 2,29$ & $\mathrm{R} \$ 1,15$ & $\mathrm{R} \$-$ & $\mathrm{R} \$-$ & $R \$-$ & $R S$ & $\mathrm{R} \$-$ & RS- & $R \$ \mathbf{S}^{-}$ & $R \$-$ & RS- & $R \$-$ & $\mathrm{R} \$-$ & $R \$-$ & $\mathrm{R} \$-$ \\
\hline OPERAÇŐES ESPECIAIS & $\mathrm{R} \$ 4.007,98$ & $\mathrm{R} \$ 583,47$ & $R \$ 4.322,85$ & R\$1.751,95 & $\mathrm{R} \$ 1.341,89$ & R\$1.069,13 & R\$1.067,48 & R\$9.328,06 & $\mathrm{R} \$ 276,78$ & $\mathrm{R} \$ 3.741,78$ & $\mathrm{R} \$ 3.815,91$ & $\mathrm{R} \$ 961,94$ & $\mathrm{R} \$ 616,02$ & $\mathrm{R} \$ 940,42$ & $\begin{array}{l}\text { R\$12.633,0 } \\
2\end{array}$ & $\mathrm{R} \$ 788,21$ & RS- \\
\hline $\begin{array}{l}0904 \text { - Operaçōes Especiais: } \\
\text { Outras Transferências }\end{array}$ & $\mathrm{R} \$ 104,11$ & $R \$ 111,38$ & RS- & RS- & RS- & RS- & RS- & RS- & RS- & RS- & RS- & RS- & RS- & RS- & RS\$- & RS- & RS- \\
\hline $\begin{array}{l}0909 \text { - Operações Especiais: } \\
\text { Outros Encargos Especiais }\end{array}$ & $R \$ 3.903,87$ & $R \$ 472,09$ & $\mathrm{R} \$ 4.322,85$ & $\mathrm{R} \$ 1.751,95$ & $\mathrm{R} \$ 1.341,89$ & $\mathrm{R} \$ 1.069,13$ & $\mathrm{R} \$ 1.067,48$ & $R \$ 9.328,06$ & $R \$ 276,78$ & $\mathrm{R} \$ 3.741,78$ & $\mathrm{R} \$ 3.815,91$ & $\mathrm{R} \$ 961,94$ & $R \$ 616,02$ & $R \$ 940,42$ & $\begin{array}{l}\mathrm{R} \$ 12.633,0 \\
2\end{array}$ & $\mathrm{R} \$ 788,21$ & RS- \\
\hline $\begin{array}{l}0911 \text { - Operaçães Especiais - } \\
\text { Remuneraç̃o de Agentes } \\
\text { Financeiros }\end{array}$ & RS- & RSS- & RSS- & RS- & RSS- & RS- & RS- & RSS- & $\mathrm{RS}-$ & RS- & RS- & RSS- & RS- & R\$- & RS- & RSS- & RS- \\
\hline $\begin{array}{l}\text { PLANEJAMENTO E GESTÃO } \\
\text { PÚBLICA }\end{array}$ & $\mathrm{R} \$ 116,95$ & $\mathrm{R} \$ 101,82$ & $\mathrm{R} \$ 105,01$ & $\mathrm{R} \$ 76,42$ & $\mathrm{R} \$ 190,92$ & $\mathrm{R} \$ 320,09$ & $\mathrm{R} \$ 273,46$ & $\mathrm{R} \$ 344,31$ & $\mathrm{R} \$ 210,41$ & $\mathrm{R} \$ 152,40$ & $\mathrm{R} \$ 151,97$ & $\mathrm{R} \$ 102,31$ & R\$1.000,33 & $\mathrm{R} \$ 1.061,31$ & R\$1.048,71 & R\$1.106,36 & R\$1.109,28 \\
\hline $\begin{array}{l}0138 \text { - Gerenciamento da } \\
\text { Estrutura Fundiária }\end{array}$ & $\mathrm{R} \$ 54,11$ & $\mathrm{R} \$ 44,35$ & $\mathrm{R} \$ 51,21$ & $R \$ 35,53$ & RS- & RS- & RS- & RS- & RS- & RS- & RS- & RS- & RS- & RS- & RS- & RS- & RS- \\
\hline $\begin{array}{l}\text { O133 - Gerenciamento da } \\
\text { Estrutura Fundiária e Destinação de } \\
\text { Terras Públicas }\end{array}$ & RS- & RS- & RS- & RS- & RS- & RS- & RS- & RS- & $R \$ 63,90$ & $\mathrm{R} \$ 49,20$ & $R \$ 70,37$ & $R \$ 47,28$ & RS- & R\$- & RS- & R\$- & RS- \\
\hline $\begin{array}{l}0138 \text { - Regularizacão e } \\
\text { Gerenciamento da Estrutura } \\
\text { Fundiária }\end{array}$ & RS- & RS- & RS- & RS- & $R \$ 82,59$ & $R \$ 123,10$ & $R \$ 98,47$ & $R \$ 71,24$ & $R \$-$ & RŞ- & RS- & RS- & RS- & RS\$- & RS- & RS- & RS- \\
\hline $\begin{array}{l}0310 \text { - Gestão da Política de } \\
\text { Desenvolvimento Urbano }\end{array}$ & $\mathrm{R} \$ 4,69$ & $\mathrm{R} \$ 7,48$ & $\mathrm{R} \$ 12,29$ & $\mathrm{R} \$ 6,45$ & $R \$ 23,87$ & $\mathrm{R} \$ 59,03$ & $\mathrm{R} \$ 104,81$ & $R \$ 207,01$ & $R \$ 93,88$ & $\mathrm{R} \$ 52,01$ & $\mathrm{R} \$ 33,26$ & $\mathrm{R} \$ 14,14$ & RS- & RS- & RS- & RS- & RS- \\
\hline 0311 - Gestão Urbana & $\mathrm{R} \$ 11,64$ & $\mathrm{R} \$ 14,70$ & RS- & RS- & RS- & RS- & RS- & RS- & RS- & RS- & RS- & RS- & RS- & RS- & $R \$-$ & RS- & RS- \\
\hline $\begin{array}{l}0311 \text { - Gestão Urbana e } \\
\text { Metropolitana }\end{array}$ & $\mathrm{RS}-$ & RS- & $R \$ 3,56$ & $\mathrm{R} \$ 1,27$ & RS- & RS- & RS- & RS- & RS- & RS- & RS- & RS- & RS- & RSS- & RS- & RS- & RS- \\
\hline $\begin{array}{l}0794 \text { - Gestão do Patrimônio } \\
\text { Imobiliário da União }\end{array}$ & RS- & RS- & RS- & RS- & $R \$ 40,48$ & $\mathrm{R} \$ 49,25$ & $R \$ 45,74$ & $R \$ 42,56$ & $R \$ 39,06$ & $\mathrm{R} \$ 43,70$ & $R \$ 43,95$ & $R \$ 38,65$ & RS- & RS- & RS- & $R \$-$ & RS- \\
\hline $\begin{array}{l}0794 \text { - Gestão do Patrimônio } \\
\text { Público }\end{array}$ & $\mathrm{R} \$ 46,49$ & $\mathrm{R} \$ 35,29$ & $R \$ 37,95$ & $\mathrm{R} \$ 33,17$ & RS- & RS- & RS- & RS- & RS- & RS- & RS- & RS- & RS- & RS- & RS- & RS- & RS- \\
\hline $\begin{array}{l}1136 \text { - Fortalecimento da Gestão } \\
\text { Municipal Urbana }\end{array}$ & RS- & RSS- & RSS- & RS- & $R \$ 43,98$ & RSS- & RS- & RȘ- & RS- & RŞ- & RS- & RȘ- & RȘ- & RS- & RȘ- & RŞ- & RS- \\
\hline $\begin{array}{l}1136 \text { - Fortalecimento da Gestão } \\
\text { Urbana }\end{array}$ & RS- & RS- & RS- & RS- & RS- & $\mathrm{R} \$ 88,71$ & $R \$ 24,45$ & $R \$ 23,50$ & $R \$ 13,57$ & $\mathrm{R} \$ 7,48$ & $R \$ 4,39$ & $\mathrm{R} \$ 2,24$ & RS- & RS- & RS- & RS- & RS- \\
\hline 2054 - Planejamento Urbano & RS- & $R S-$ & $R \$-$ & $R \$-$ & RS- & $\mathrm{R} \$-$ & RS- & $\mathrm{RS}-$ & RS- & RS- & RS- & $\mathrm{RS}-$ & $R \$ 12,90$ & $R \$ 5,60$ & $R \$ 3,96$ & $R \$ 10,31$ & $R \$ 24,14$ \\
\hline $\begin{array}{l}2116 \text { - Programa de Gestão e } \\
\text { Manutenção do Ministério das } \\
\text { Cidades }\end{array}$ & RS- & RS- & RS- & RS- & RS- & RS- & RS- & RS- & RS- & RS- & RS- & RS- & $\mathrm{R} \$ 987,43$ & $R \$ 1.055,71$ & $\mathrm{R} \$ 1.044,75$ & $R \$ 1.096,05$ & $\mathrm{R} \$ 1.085,15$ \\
\hline SANEAMENTO BÁSICO & $R \$ 2.487,14$ & $R \$ 6.792,60$ & $\mathrm{R} \$ 2.999,76$ & $\mathrm{R} \$ 1.057,23$ & R\$1.665,59 & R\$2.430,27 & $R \$ 2.435,67$ & $\mathrm{R} \$ 610,94$ & $R \$ 864,05$ & R\$1.085,77 & $R \$ 1.245,29$ & $\mathrm{R} \$ 1.197,70$ & R\$1.439,98 & $\mathrm{R} \$ 693,20$ & $\mathrm{R} \$ 435,55$ & $R \$ 321,10$ & $\mathrm{R} \$ 599,51$ \\
\hline 0119 - Saneamento Básico & $R \$ 682,69$ & $\mathrm{R} \$ 3.616,96$ & $\mathrm{R} \$ 1.553,62$ & $R \$ 414,33$ & RS- & RSS- & RS\$- & RS- & RS\$- & RS- & RS & RS\$- & RŞ- & RŞ- & RS- & RS- & RS- \\
\hline $\begin{array}{l}0122 \text { - Saneamento Ambiental } \\
\text { Urbano }\end{array}$ & RS- & RS- & RS- & RS- & $\mathrm{R} \$ 1.126,80$ & $R \$ 1.366,04$ & RS- & RS- & RSS- & RȘ- & RS- & RS- & RS- & RS- & RS- & RS- & RS- \\
\hline 0122 - Saneamento É Vida & $\mathrm{R} \$ 7,74$ & $\mathrm{R} \$-$ & $\mathrm{R} \$ 207,27$ & $\mathrm{R} \$ 120,98$ & R\$- & RS- & RS- & RS- & RS- & RS- & $\mathrm{R} \$-$ & R\$- & RS- & R\$- & RS- & RS- & RS- \\
\hline $\begin{array}{l}0122 \text { - Serviços Urbanos de Água } \\
\text { e Esgoto }\end{array}$ & $\mathrm{RS}-$ & RS- & Rș- & RS- & RS\$- & RS- & $R \$ 1.717,71$ & $R \$ 200,84$ & $\mathrm{R} \$ 479,90$ & $\mathrm{R} \$ 717,56$ & $\mathrm{R} \$ 525,71$ & $\mathrm{R} \$ 702,46$ & RS- & RS\$- & RS- & RȘ- & RS- \\
\hline 0495 - Proágua - Gestão & $\mathrm{R} \$ 152,58$ & $\mathrm{R} \$ 290,60$ & $R \$ 47,72$ & $\mathrm{R} \$ 23,97$ & RS- & RS- & RS- & RS- & RS- & RS- & $R \$-$ & RS- & $R \$-$ & RS- & $R \$-$ & RS- & RS- \\
\hline
\end{tabular}




\begin{tabular}{|c|c|c|c|c|c|c|c|c|c|c|c|c|c|c|c|c|c|}
\hline 0515 - Infra-Estrutura Hídrica & RS- & RS\$- & RS- & R\$- & RS- & RS- & RS- & RS- & $R \$ 369,28$ & $R \$ 284,50$ & $R \$ 469,74$ & $\mathrm{R} \$ 350,87$ & RS\$- & RS- & RS- & RS\$- & RS- \\
\hline 0515 - Proágua - Infra-estrutura & $\mathrm{R} \$ 1.601,10$ & RS- & RS- & RS- & RS- & RS- & R\$- & RS- & RS- & RS- & RS- & RS- & RS- & RS- & RS- & RS- & RS- \\
\hline $\begin{array}{l}\text { O515- PROÁGUA INFRA- } \\
\text { ESTRUTURA }\end{array}$ & RS- & $R \$ 2.746,56$ & $\mathrm{R} \$ 1.096,03$ & $\mathrm{R} \$ 487,75$ & $R \$ 339,60$ & $R \$ 666,00$ & $R \$ 354,39$ & $\mathrm{R} \$ 383,95$ & R\$- & R\$- & RS- & R\$- & RS- & RS- & R\$- & RS- & RS- \\
\hline 0516 - Brasil Joga Limpo & $\mathrm{R} \$ 43,04$ & $R \$ 138,48$ & $R \$ 74,98$ & $R \$ 4,82$ & RS- & R\$- & RS- & RS- & RS- & RS- & RS- & R\$- & RS- & R\$- & RS- & RS- & RS- \\
\hline 0516 - Viver Sem Contaminação & RS- & RŞ- & RS- & RS- & $\mathrm{R} \$ 6,71$ & $\mathrm{R} \$ 4,84$ & RS- & RS- & RS- & RS- & RS- & RS- & RS- & RS- & RS- & RS- & RS- \\
\hline $\begin{array}{l}1138 \text { - Drenagem Urbana e } \\
\text { Controle de Erosão Marítima e } \\
\text { Fluvial }\end{array}$ & RŞ- & RŞ- & RS- & RS- & RȘ- & RS- & RS- & RS- & $R \$ 7,80$ & $\mathrm{R} \$ 80,22$ & $\mathrm{R} \$ 246,31$ & $\mathrm{R} \$ 134,43$ & RS- & RSS- & RS- & RS- & RS- \\
\hline $\begin{array}{l}1138 \text { - Drenagem Urbana } \\
\text { Sustentável }\end{array}$ & RS- & R\$- & RS- & RS- & $R \$ 96,41$ & $\mathrm{R} \$ 275,37$ & $\mathrm{R} \$ 263,10$ & $R \$ 15,49$ & R\$- & R\$- & R\$- & RS- & RS- & RS- & R\$- & RS- & RŞ- \\
\hline 2067 - Resíduos Sólidos & R\$- & R\$- & R\$- & RS- & R\$- & R\$- & R\$- & RS- & RS- & R\$- & RS- & RS- & $\mathrm{R} \$ 39,27$ & $R \$ 9,65$ & $\mathrm{R} \$ 10,67$ & $\mathrm{R} \$ 4,17$ & RS- \\
\hline 2068 - Saneamento Básico & RŞ- & RȘ- & RS- & RȘ- & RȘ- & RȘ- & RŞ- & RȘ- & RȘ- & RS- & RŞ- & RS - & $\mathrm{R} \$ 1.400,71$ & $\mathrm{R} \$ 683,54$ & $\mathrm{R} \$ 424,89$ & $\mathrm{R} \$ 316,93$ & $\mathrm{R} \$ 599,51$ \\
\hline $\begin{array}{l}8007 \text { - Gestão de Resíduos } \\
\text { Sólidos Urbanos }\end{array}$ & RS- & R\$- & $\mathrm{R} \$ 20,14$ & $\mathrm{R} \$ 5,38$ & RS- & RS- & R\$- & RS- & $\mathrm{R} \$-$ & RS- & RS- & RS- & RS- & RS- & RŞ- & RS- & RS- \\
\hline 8007 - Resíduos Sólidos Urbanos & RS- & RS- & RS- & RS- & $R \$ 96,07$ & $R \$ 118,04$ & $R \$ 100,47$ & $\mathrm{R} \$ 10,66$ & $\mathrm{R} \$ 7,07$ & $R \$ 3,49$ & $R \$ 3,53$ & $\mathrm{R} \$ 9,94$ & RS- & RS- & RS- & RŞ- & RS- \\
\hline
\end{tabular}

Quadro Anexo 3: Classificações programáticas por eixo do desenvolvimento urbano - Recursos liquidados por ano. Valores em milhões. Ano referência de valores: 2016. Fonte: Sistema Integrado de Planejamento e Orçamento, Ministério do Planejamento, Desenvolvimento e Gestão do Governo Federal. Elaboração nossa. 
FINANCIAMENTO FISCAL DO DESENVOLVIMENTO URBANO: VALORES EMPENHADOS POR ESTADO

\begin{tabular}{|c|c|c|c|c|c|c|c|c|c|c|c|c|c|c|c|c|c|}
\hline & 2000 & 2001 & 2002 & 2003 & 2004 & 2005 & 2006 & 2007 & 2008 & 2009 & 2010 & 2011 & 2012 & 2013 & 2014 & 2015 & 2016 \\
\hline Acre & $\mathrm{R} \$ 35,1$ & $\mathrm{R} \$ 84,1$ & $\mathrm{R} \$ 15,2$ & $\mathrm{R} \$ 11,5$ & $\mathrm{R} \$ 11,5$ & $\mathrm{R} \$ 36,1$ & $\mathrm{R} \$ 43,1$ & $\mathrm{R} \$ 80,7$ & $\mathrm{R} \$ 91,2$ & $R \$ 175,2$ & $\mathrm{R} \$ 11,6$ & $\mathrm{R} \$ 42,8$ & $\mathrm{R} \$ 9,4$ & $\mathrm{R} \$ 14,0$ & $R \$ 25,0$ & $\mathrm{R} \$ 22,6$ & $\mathrm{R} \$ 10,2$ \\
\hline Alagoas & $\mathrm{R} \$ 233,1$ & $R \$ 473,6$ & $R \$ 198,8$ & $\mathrm{R} \$ 59,6$ & $\mathrm{R} \$ 86,1$ & $R \$ 291,0$ & $R \$ 196,7$ & $\mathrm{R} \$ 584,7$ & $R \$ 334,6$ & $\mathrm{R} \$ 458,7$ & $\mathrm{R} \$ 348,7$ & $\mathrm{R} \$ 208,5$ & $R \$ 20,6$ & $\mathrm{R} \$ 31,2$ & $R \$ 76,2$ & $\mathrm{R} \$ 14,3$ & $\mathrm{R} \$ 44,5$ \\
\hline Amapá & $R \$ 21,1$ & $R \$ 58,7$ & $R \$ 20,1$ & $\mathrm{R} \$ 11,7$ & $\mathrm{R} \$ 11,6$ & $R \$ 37,6$ & $R \$ 58,9$ & $R \$ 98,4$ & $R \$ 69,0$ & $R \$ 106,1$ & $\mathrm{R} \$ 31,8$ & $\mathrm{R} \$ 18,6$ & $\mathrm{R} \$ 0,0$ & $R \$ 0,0$ & $\mathrm{R} \$ 8,7$ & $\mathrm{R} \$ 9,1$ & $\mathrm{R} \$ 8,1$ \\
\hline Amazonas & $\mathrm{R} \$ 76,1$ & $R \$ 154,6$ & $R \$ 57,8$ & $\mathrm{R} \$ 57,5$ & $\mathrm{R} \$ 28,8$ & $\mathrm{R} \$ 52,3$ & $R \$ 72,4$ & $\mathrm{R} \$ 86,4$ & $\mathrm{R} \$ 69,4$ & $R \$ 98,0$ & $\mathrm{R} \$ 48,0$ & $\mathrm{R} \$ 34,5$ & $\mathrm{R} \$ 0,0$ & $\mathrm{R} \$ 0,6$ & $\mathrm{R} \$ 0,9$ & $\mathrm{R} \$ 1,9$ & $\mathrm{R} \$ 10,1$ \\
\hline Bahia & $R \$ 209,0$ & $R \$ 632,4$ & $\mathrm{R} \$ 215,2$ & $\mathrm{R} \$ 69,8$ & $\mathrm{R} \$ 252,5$ & $R \$ 468,5$ & $R \$ 439,6$ & $R \$ 740,3$ & $R \$ 787,8$ & $\mathrm{R} \$ 805,8$ & $R \$ 754,8$ & $\mathrm{R} \$ 639,9$ & $\mathrm{R} \$ 162,0$ & $R \$ 207,3$ & $\mathrm{R} \$ 146,4$ & $\mathrm{R} \$ 116,2$ & $\mathrm{R} \$ 145,3$ \\
\hline Ceara & $R \$ 260,9$ & $R \$ 761,9$ & $\mathrm{R} \$ 461,4$ & $\mathrm{R} \$ 178,0$ & $R \$ 306,0$ & $R \$ 548,8$ & $R \$ 486,2$ & $\mathrm{R} \$ 771,5$ & $\mathrm{R} \$ 883,7$ & $\mathrm{R} \$ 859,7$ & $\mathrm{R} \$ 852,7$ & $R \$ 534,8$ & $\mathrm{R} \$ 165,5$ & $\mathrm{R} \$ 122,3$ & $\mathrm{R} \$ 222,1$ & $\mathrm{R} \$ 72,9$ & $\mathrm{R} \$ 61,9$ \\
\hline $\begin{array}{l}\text { Distrito } \\
\text { Federal }\end{array}$ & $\mathrm{R} \$ 136,6$ & $\mathrm{R} \$ 168,1$ & $\mathrm{R} \$ 31,1$ & $R \$ 7,2$ & $\mathrm{R} \$ 3,4$ & $\mathrm{R} \$ 31,7$ & $\mathrm{R} \$ 5,1$ & $\mathrm{R} \$ 82,6$ & $\mathrm{R} \$ 39,9$ & $\mathrm{R} \$ 47,9$ & $\mathrm{R} \$ 19,0$ & $\mathrm{R} \$ 11,8$ & $\mathrm{R} \$ 8,7$ & $\mathrm{R} \$ 8,8$ & $\mathrm{R} \$ 1,9$ & $\mathrm{R} \$ 57,0$ & $\mathrm{R} \$ 60,8$ \\
\hline $\begin{array}{l}\text { Espirito } \\
\text { Santo }\end{array}$ & $R \$ 104,2$ & $\mathrm{R} \$ 175,4$ & $R \$ 73,0$ & $R \$ 32,0$ & $R \$ 54,7$ & $R \$ 59,3$ & $R \$ 79,0$ & $R \$ 115,2$ & $\mathrm{R} \$ 113,4$ & $R \$ 173,8$ & $\mathrm{R} \$ 33,5$ & $\mathrm{R} \$ 89,3$ & $\mathrm{R} \$ 16,2$ & $\mathrm{R} \$ 20,6$ & $\mathrm{R} \$ 18,4$ & $\mathrm{R} \$ 12,2$ & $R \$ 17,0$ \\
\hline Goiás & $\mathrm{R} \$ 251,1$ & $\mathrm{R} \$ 303,3$ & $\mathrm{R} \$ 139,1$ & $\mathrm{R} \$ 71,9$ & $\mathrm{R} \$ 118,6$ & $\mathrm{R} \$ 227,1$ & $\mathrm{R} \$ 216,9$ & $\mathrm{R} \$ 479,1$ & $R \$ 350,9$ & $\mathrm{R} \$ 384,9$ & $R \$ 234,2$ & $R \$ 220,2$ & $\mathrm{R} \$ 22,9$ & $\mathrm{R} \$ 54,0$ & $\mathrm{R} \$ 40,0$ & $\mathrm{R} \$ 53,7$ & $\mathrm{R} \$ 76,6$ \\
\hline Maranhão & $\mathrm{R} \$ 110,5$ & $\mathrm{R} \$ 421,6$ & $\mathrm{R} \$ 90,5$ & $\mathrm{R} \$ 52,9$ & $\mathrm{R} \$ 92,2$ & $\mathrm{R} \$ 113,9$ & $\mathrm{R} \$ 165,9$ & $R \$ 267,2$ & $\mathrm{R} \$ 334,8$ & $R \$ 339,6$ & $\mathrm{R} \$ 111,1$ & $\mathrm{R} \$ 223,5$ & $\mathrm{R} \$ 46,7$ & $\mathrm{R} \$ 47,3$ & $\mathrm{R} \$ 55,1$ & $\mathrm{R} \$ 69,8$ & $\mathrm{R} \$ 57,4$ \\
\hline Mato Grosso & $\mathrm{R} \$ 76,1$ & $\mathrm{R} \$ 88,0$ & $\mathrm{R} \$ 69,6$ & $\mathrm{R} \$ 49,2$ & $\mathrm{R} \$ 71,8$ & $R \$ 126,2$ & $R \$ 120,3$ & $R \$ 262,2$ & $R \$ 175,0$ & $\mathrm{R} \$ 194,9$ & $\mathrm{R} \$ 109,1$ & $R \$ 74,4$ & $\mathrm{R} \$ 13,9$ & $\mathrm{R} \$ 34,5$ & $R \$ 24,2$ & $\mathrm{R} \$ 31,1$ & $\mathrm{R} \$ 21,0$ \\
\hline $\begin{array}{l}\text { Mato Grosso } \\
\text { do Sul }\end{array}$ & $R \$ 73,3$ & $R \$ 160,9$ & $\mathrm{R} \$ 113,7$ & $\mathrm{R} \$ 104,1$ & $\mathrm{R} \$ 56,0$ & $R \$ 96,9$ & $\mathrm{R} \$ 141,1$ & $R \$ 247,2$ & $R \$ 261,0$ & $\mathrm{R} \$ 186,2$ & $\mathrm{R} \$ 47,2$ & $\mathrm{R} \$ 81,0$ & $\mathrm{R} \$ 38,8$ & $\mathrm{R} \$ 50,5$ & $\mathrm{R} \$ 30,0$ & $\mathrm{R} \$ 38,7$ & $\mathrm{R} \$ 67,9$ \\
\hline Minas Gerais & $R \$ 279,4$ & $\mathrm{R} \$ 366,1$ & $R \$ 340,0$ & $R \$ 124,4$ & $\mathrm{R} \$ 261,3$ & $R \$ 410,3$ & $R \$ 340,9$ & $R \$ 780,8$ & $\mathrm{R} \$ 646,0$ & $\mathrm{R} \$ 638,2$ & $R \$ 500,4$ & $\mathrm{R} \$ 591,7$ & $\mathrm{R} \$ 374,5$ & $R \$ 160,6$ & $\mathrm{R} \$ 142,2$ & $\mathrm{R} \$ 144,8$ & $\mathrm{R} \$ 159,2$ \\
\hline Para & $\mathrm{R} \$ 36,8$ & $R \$ 439,6$ & $\mathrm{R} \$ 195,6$ & $\mathrm{R} \$ 25,2$ & $\mathrm{R} \$ 69,2$ & $\mathrm{R} \$ 111,9$ & $\mathrm{R} \$ 125,5$ & $R \$ 165,2$ & $\mathrm{R} \$ 220,1$ & $\mathrm{R} \$ 266,6$ & $\mathrm{R} \$ 165,8$ & $\mathrm{R} \$ 172,0$ & $\mathrm{R} \$ 32,9$ & $\mathrm{R} \$ 28,3$ & $\mathrm{R} \$ 41,7$ & $\mathrm{R} \$ 36,1$ & $\mathrm{R} \$ 41,9$ \\
\hline Paraíba & $R \$ 266,6$ & $R \$ 423,6$ & $R \$ 200,8$ & $\mathrm{R} \$ 50,7$ & $R \$ 108,5$ & $R \$ 230,0$ & $R \$ 214,8$ & $\mathrm{R} \$ 451,2$ & $R \$ 317,3$ & $\mathrm{R} \$ 214,7$ & $\mathrm{R} \$ 101,3$ & $\mathrm{R} \$ 100,0$ & $\mathrm{R} \$ 151,7$ & $\mathrm{R} \$ 26,7$ & $\mathrm{R} \$ 70,8$ & $\mathrm{R} \$ 32,1$ & $\mathrm{R} \$ 57,1$ \\
\hline Paraná & $\mathrm{R} \$ 59,2$ & $\mathrm{R} \$ 111,7$ & $\mathrm{R} \$ 86,2$ & $\mathrm{R} \$ 30,6$ & $\mathrm{R} \$ 71,5$ & $\mathrm{R} \$ 146,6$ & $\mathrm{R} \$ 104,8$ & $\mathrm{R} \$ 179,5$ & $\mathrm{R} \$ 176,9$ & $\mathrm{R} \$ 194,9$ & $\mathrm{R} \$ 134,4$ & $\mathrm{R} \$ 154,0$ & $\mathrm{R} \$ 96,1$ & $\mathrm{R} \$ 107,3$ & $\mathrm{R} \$ 79,1$ & $\mathrm{R} \$ 84,5$ & $\mathrm{R} \$ 84,1$ \\
\hline Pernambuco & $\mathrm{R} \$ 431,6$ & $\mathrm{R} \$ 761,6$ & $R \$ 396,4$ & $\mathrm{R} \$ 201,7$ & $R \$ 295,7$ & $R \$ 199,4$ & $R \$ 362,2$ & $\mathrm{R} \$ 731,9$ & $\mathrm{R} \$ 781,5$ & $R \$ 677,0$ & $\mathrm{R} \$ 591,9$ & $\mathrm{R} \$ 411,4$ & $\mathrm{R} \$ 111,0$ & $\mathrm{R} \$ 247,4$ & $\mathrm{R} \$ 87,1$ & $\mathrm{R} \$ 53,8$ & $R \$ 132,0$ \\
\hline Piauí & $R \$ 171,4$ & $R \$ 322,1$ & $R \$ 282,5$ & $\mathrm{R} \$ 80,6$ & $R \$ 170,4$ & $R \$ 192,2$ & $\mathrm{R} \$ 143,1$ & $R \$ 350,9$ & $R \$ 255,6$ & $\mathrm{R} \$ 97,5$ & $\mathrm{R} \$ 81,3$ & $\mathrm{R} \$ 85,7$ & $\mathrm{R} \$ 21,4$ & $\mathrm{R} \$ 29,3$ & $\mathrm{R} \$ 32,6$ & $\mathrm{R} \$ 29,6$ & $\mathrm{R} \$ 42,1$ \\
\hline $\begin{array}{l}\text { Rio de } \\
\text { Janeiro }\end{array}$ & $\mathrm{R} \$ 246,7$ & $\mathrm{R} \$ 461,7$ & $\mathrm{R} \$ 130,4$ & $\mathrm{R} \$ 69,8$ & $\mathrm{R} \$ 121,6$ & $\mathrm{R} \$ 250,9$ & $\mathrm{R} \$ 244,1$ & $\mathrm{R} \$ 899,7$ & $\mathrm{R} \$ 983,9$ & $\mathrm{R} \$ 1.297,0$ & $\mathrm{R} \$ 1.233,9$ & $\mathrm{R} \$ 619,4$ & $\mathrm{R} \$ 66,5$ & $\mathrm{R} \$ 84,5$ & $\mathrm{R} \$ 80,0$ & $R \$ 62,6$ & $R \$ 62,6$ \\
\hline $\begin{array}{l}\text { Rio Grande } \\
\text { do Norte }\end{array}$ & $R \$ 205,0$ & $R \$ 273,5$ & $R \$ 125,8$ & $\mathrm{R} \$ 55,4$ & $R \$ 116,6$ & $\mathrm{R} \$ 112,1$ & $\mathrm{R} \$ 88,4$ & $R \$ 212,9$ & $R \$ 326,8$ & $\mathrm{R} \$ 152,0$ & $\mathrm{R} \$ 109,0$ & $\mathrm{R} \$ 107,1$ & $\mathrm{R} \$ 227,0$ & $\mathrm{R} \$ 33,0$ & $\mathrm{R} \$ 69,4$ & $\mathrm{R} \$ 33,5$ & $\mathrm{R} \$ 30,7$ \\
\hline $\begin{array}{l}\text { Rio Grande } \\
\text { do Sul }\end{array}$ & $\mathrm{R} \$ 232,1$ & $\mathrm{R} \$ 142,7$ & $R \$ 117,3$ & $\mathrm{R} \$ 188,8$ & $\mathrm{R} \$ 282,0$ & $R \$ 308,0$ & $\mathrm{R} \$ 313,3$ & $R \$ 456,2$ & $\mathrm{R} \$ 591,9$ & $\mathrm{R} \$ 1.021,2$ & $\mathrm{R} \$ 1.094,8$ & $\mathrm{R} \$ 840,7$ & $\mathrm{R} \$ 889,8$ & $\mathrm{R} \$ 247,5$ & $\mathrm{R} \$ 203,6$ & $\mathrm{R} \$ 318,9$ & $R \$ 320,9$ \\
\hline Rondônia & $\mathrm{R} \$ 80,0$ & $\mathrm{R} \$ 106,9$ & $R \$ 70,3$ & $\mathrm{R} \$ 18,5$ & $\mathrm{R} \$ 24,1$ & $\mathrm{R} \$ 64,2$ & $\mathrm{R} \$ 41,0$ & $\mathrm{R} \$ 60,1$ & $\mathrm{R} \$ 63,0$ & $\mathrm{R} \$ 248,0$ & $\mathrm{R} \$ 179,7$ & $\mathrm{R} \$ 57,1$ & $\mathrm{R} \$ 8,2$ & $R \$ 3,0$ & $\mathrm{R} \$ 0,0$ & $\mathrm{R} \$ 0,3$ & $\mathrm{R} \$ 18,0$ \\
\hline Roraima & $\mathrm{R} \$ 78,7$ & $\mathrm{R} \$ 80,8$ & $\mathrm{R} \$ 33,8$ & $\mathrm{R} \$ 9,7$ & $\mathrm{R} \$ 16,5$ & $\mathrm{R} \$ 12,0$ & $\mathrm{R} \$ 54,3$ & $\mathrm{R} \$ 32,1$ & $\mathrm{R} \$ 70,4$ & $\mathrm{R} \$ 61,8$ & $\mathrm{R} \$ 30,7$ & $\mathrm{R} \$ 11,3$ & $\mathrm{R} \$ 0,0$ & $\mathrm{R} \$ 4,3$ & $\mathrm{R} \$ 7,1$ & $R \$ 24,7$ & $\mathrm{R} \$ 36,8$ \\
\hline $\begin{array}{l}\text { Santa } \\
\text { Catarina }\end{array}$ & $\mathrm{R} \$ 149,3$ & $\mathrm{R} \$ 205,9$ & $\mathrm{R} \$ 180,6$ & $\mathrm{R} \$ 41,5$ & $\mathrm{R} \$ 80,0$ & $\mathrm{R} \$ 100,8$ & $R \$ 93,6$ & $\mathrm{R} \$ 124,9$ & $\mathrm{R} \$ 194,0$ & $\mathrm{R} \$ 276,3$ & $\mathrm{R} \$ 238,6$ & $\mathrm{R} \$ 179,5$ & $\mathrm{R} \$ 56,1$ & $\mathrm{R} \$ 66,1$ & $\mathrm{R} \$ 54,7$ & $\mathrm{R} \$ 53,5$ & $\mathrm{R} \$ 70,5$ \\
\hline São Paulo & $\mathrm{R} \$ 859,1$ & $\mathrm{R} \$ 712,8$ & $\mathrm{R} \$ 671,2$ & $\mathrm{R} \$ 133,7$ & $\mathrm{R} \$ 429,1$ & $R \$ 574,5$ & $\mathrm{R} \$ 632,0$ & $R \$ 2.033,5$ & $\mathrm{R} \$ 1.015,4$ & $\mathrm{R} \$ 1.425,7$ & $\mathrm{R} \$ 1.289,9$ & $R \$ 917,2$ & $\mathrm{R} \$ 190,1$ & $R \$ 244,0$ & $\mathrm{R} \$ 252,7$ & $R \$ 202,0$ & $\mathrm{R} \$ 231,3$ \\
\hline Sergipe & $\mathrm{R} \$ 141,4$ & $\mathrm{R} \$ 213,4$ & $\mathrm{R} \$ 143,4$ & $\mathrm{R} \$ 40,2$ & $\mathrm{R} \$ 83,1$ & $\mathrm{R} \$ 87,8$ & $\mathrm{R} \$ 68,5$ & $\mathrm{R} \$ 157,3$ & $\mathrm{R} \$ 156,3$ & $\mathrm{R} \$ 200,5$ & $\mathrm{R} \$ 74,8$ & $\mathrm{R} \$ 39,8$ & $\mathrm{R} \$ 17,5$ & $\mathrm{R} \$ 33,7$ & $\mathrm{R} \$ 37,5$ & $\mathrm{R} \$ 27,0$ & $\mathrm{R} \$ 38,6$ \\
\hline Tocantins & $\mathrm{R} \$ 55,9$ & $\mathrm{R} \$ 453,4$ & $\mathrm{R} \$ 166,9$ & $R \$ 37,1$ & $R \$ 27,9$ & $R \$ 70,1$ & $R \$ 75,8$ & $\mathrm{R} \$ 142,4$ & $\mathrm{R} \$ 169,6$ & $\mathrm{R} \$ 140,4$ & $R \$ 36,6$ & $\mathrm{R} \$ 42,4$ & $\mathrm{R} \$ 27,2$ & $\mathrm{R} \$ 47,4$ & $\mathrm{R} \$ 31,0$ & $R \$ 37,2$ & $\mathrm{R} \$ 23,2$ \\
\hline $\begin{array}{l}\text { Não } \\
\text { especificado }\end{array}$ & $\mathrm{R} \$ 5.808,1$ & $\mathrm{R} \$ 4.175,2$ & $R \$ 24.009,2$ & $\mathrm{R} \$ 9.429,3$ & $\mathrm{R} \$ 3.781,9$ & $\mathrm{R} \$ 4.313,6$ & $\mathrm{R} \$ 5.079,6$ & $\mathrm{R} \$ 17.249,5$ & $\mathrm{R} \$ 6.900,7$ & $\mathrm{R} \$ 15.844,6$ & $\mathrm{R} \$ 18.467,5$ & $\mathrm{R} \$ 23.233,8$ & $\mathrm{R} \$ 23.267,3$ & $\mathrm{R} \$ 27.298,2$ & $\mathrm{R} \$ 39.701,0$ & $\mathrm{R} \$ 23.966,0$ & $\mathrm{R} \$ 11.452,6$ \\
\hline
\end{tabular}

Quadro Anexo 4: Territorialização do financiamento fiscal do desenvolvimento urbano: Valores empenhados por Estado. Valores em milhões. Ano referência de valores: 2016. Fonte: Sistema Integrado de Planejamento e Orçamento, Ministério do Planejamento, Desenvolvimento e Gestão do Governo Federal. Elaboração nossa. 
FINANCIAMENTO FISCAL DO DESENVOLVIMENTO URBANO: VALORES LIQUIDADOS POR ESTADO

\begin{tabular}{|c|c|c|c|c|c|c|c|c|c|c|c|c|c|c|c|c|c|}
\hline & 2000 & 2001 & 2002 & 2003 & 2004 & 2005 & 2006 & 2007 & 2008 & 2009 & 2010 & 2011 & 2012 & 2013 & 2014 & 2015 & 2016 \\
\hline Acre & $\mathrm{R} \$ 35,1$ & $\mathrm{R} \$ 84,1$ & $\mathrm{R} \$ 15,2$ & $\mathrm{R} \$ 11,5$ & $\mathrm{R} \$ 11,5$ & $\mathrm{R} \$ 36,1$ & $\mathrm{R} \$ 43,1$ & $\mathrm{R} \$ 0,1$ & $R \$ 28,3$ & $\mathrm{R} \$ 45,8$ & $\mathrm{R} \$ 0,0$ & $\mathrm{R} \$ 1,5$ & $R \$ 0,0$ & $\mathrm{R} \$ 0,0$ & $\mathrm{R} \$ 0,0$ & $R \$ 0,0$ & $\mathrm{R} \$ 0,0$ \\
\hline Alagoas & $\mathrm{R} \$ 233,1$ & $\mathrm{R} \$ 473,6$ & $\mathrm{R} \$ 198,8$ & $\mathrm{R} \$ 59,6$ & $\mathrm{R} \$ 86,1$ & $\mathrm{R} \$ 291,0$ & $\mathrm{R} \$ 196,7$ & $\mathrm{R} \$ 57,8$ & $\mathrm{R} \$ 19,7$ & $R \$ 43,0$ & $\mathrm{R} \$ 41,3$ & $\mathrm{R} \$ 83,6$ & $\mathrm{R} \$ 0,4$ & $\mathrm{R} \$ 0,0$ & $\mathrm{R} \$ 0,0$ & $\mathrm{R} \$ 0,0$ & $\mathrm{R} \$ 0,0$ \\
\hline Amapá & $\mathrm{R} \$ 21,1$ & $\mathrm{R} \$ 58,7$ & $\mathrm{R} \$ 20,1$ & $\mathrm{R} \$ 11,7$ & $\mathrm{R} \$ 11,6$ & $\mathrm{R} \$ 37,6$ & $\mathrm{R} \$ 58,9$ & $\mathrm{R} \$ 0,1$ & $R \$ 19,0$ & $R \$ 0,0$ & $\mathrm{R} \$ 0,0$ & $\mathrm{R} \$ 3,4$ & $\mathrm{R} \$ 0,0$ & $\mathrm{R} \$ 0,0$ & $\mathrm{R} \$ 0,0$ & $\mathrm{R} \$ 0,0$ & $\mathrm{R} \$ 0,0$ \\
\hline Amazonas & $\mathrm{R} \$ 76,1$ & $\mathrm{R} \$ 154,6$ & $\mathrm{R} \$ 57,8$ & $\mathrm{R} \$ 57,5$ & $\mathrm{R} \$ 28,8$ & $R \$ 52,3$ & $\mathrm{R} \$ 72,4$ & $\mathrm{R} \$ 0,6$ & $\mathrm{R} \$ 14,8$ & $R \$ 2,3$ & $\mathrm{R} \$ 0,5$ & $\mathrm{R} \$ 8,3$ & $\mathrm{R} \$ 0,0$ & $\mathrm{R} \$ 0,0$ & $\mathrm{R} \$ 0,0$ & $\mathrm{R} \$ 0,0$ & $\mathrm{R} \$ 0,0$ \\
\hline Bahia & $R \$ 209,0$ & $\mathrm{R} \$ 632,4$ & $\mathrm{R} \$ 215,2$ & $R \$ 69,8$ & $\mathrm{R} \$ 252,5$ & $\mathrm{R} 468,5$ & $\mathrm{R} \$ 439,6$ & $\mathrm{R} \$ 142,3$ & $\mathrm{R} \$ 74,5$ & $R \$ 174,0$ & $\mathrm{R} \$ 188,1$ & $\mathrm{R} \$ 225,8$ & $\mathrm{R} \$ 0,0$ & $\mathrm{R} \$ 0,4$ & $\mathrm{R} \$ 0,0$ & $\mathrm{R} \$ 0,0$ & $\mathrm{R} \$ 3,1$ \\
\hline Ceara & $R \$ 260,9$ & $\mathrm{R} \$ 761,9$ & $\mathrm{R} \$ 461,4$ & $\mathrm{R} \$ 178,0$ & $R \$ 306,0$ & $R \$ 548,8$ & $\mathrm{R} \$ 486,2$ & $\mathrm{R} \$ 153,7$ & $\mathrm{R} \$ 89,7$ & $\mathrm{R} \$ 211,7$ & $\mathrm{R} \$ 551,6$ & $R \$ 326,3$ & $\mathrm{R} \$ 22,6$ & $\mathrm{R} \$ 42,9$ & $\mathrm{R} \$ 127,7$ & $\mathrm{R} \$ 0,0$ & $\mathrm{R} \$ 0,4$ \\
\hline $\begin{array}{l}\text { Distrito } \\
\text { Federal }\end{array}$ & $\mathrm{R} \$ 136,6$ & $R \$ 168,1$ & $\mathrm{R} \$ 31,1$ & $R \$ 7,2$ & $\mathrm{R} \$ 3,4$ & $\mathrm{R} \$ 31,7$ & $\mathrm{R} \$ 5,1$ & $\mathrm{R} \$ 52,9$ & $R \$ 13,8$ & $R \$ 22,0$ & $\mathrm{R} \$ 0,8$ & $\mathrm{R} \$ 0,0$ & $R \$ 0,0$ & $\mathrm{R} \$ 0,0$ & $\mathrm{R} \$ 0,0$ & $\mathrm{R} \$ 54,1$ & $\mathrm{R} \$ 51,1$ \\
\hline $\begin{array}{l}\text { Espirito } \\
\text { Santo }\end{array}$ & $\mathrm{R} \$ 104,2$ & $\mathrm{R} \$ 175,4$ & $\mathrm{R} \$ 73,0$ & $\mathrm{R} \$ 32,0$ & $\mathrm{R} \$ 54,7$ & $\mathrm{R} \$ 59,3$ & $R \$ 79,0$ & $\mathrm{R} \$ 1,4$ & $\mathrm{R} \$ 14,5$ & $\mathrm{R} \$ 48,3$ & $\mathrm{R} \$ 0,0$ & $\mathrm{R} \$ 1,3$ & $\mathrm{R} \$ 0,0$ & $\mathrm{R} \$ 0,0$ & $\mathrm{R} \$ 0,0$ & $\mathrm{R} \$ 0,0$ & $\mathrm{R} \$ 0,0$ \\
\hline Goiás & $\mathrm{R} \$ 251,1$ & $R \$ 303,3$ & $\mathrm{R} \$ 139,1$ & $\mathrm{R} \$ 71,9$ & $\mathrm{R} \$ 118,6$ & $\mathrm{R} \$ 227,1$ & $R \$ 216,9$ & $\mathrm{R} \$ 1,8$ & $R \$ 94,6$ & $\mathrm{R} \$ 132,1$ & $R \$ 48,5$ & $\mathrm{R} \$ 41,3$ & $\mathrm{R} \$ 0,0$ & $\mathrm{R} \$ 0,0$ & $\mathrm{R} \$ 0,0$ & $\mathrm{R} \$ 0,0$ & $\mathrm{R} \$ 0,4$ \\
\hline Maranhão & $R \$ 110,5$ & $\mathrm{R} \$ 421,6$ & $\mathrm{R} \$ 90,5$ & $\mathrm{R} \$ 52,9$ & $R \$ 92,2$ & $R \$ 113,9$ & $\mathrm{R} \$ 165,9$ & $\mathrm{R} \$ 1,5$ & $R \$ 108,7$ & $\mathrm{R} \$ 127,0$ & $\mathrm{R} \$ 3,1$ & $\mathrm{R} \$ 6,1$ & $\mathrm{R} \$ 0,0$ & $\mathrm{R} \$ 0,0$ & $\mathrm{R} \$ 0,0$ & $\mathrm{R} \$ 0,0$ & $\mathrm{R} \$ 0,1$ \\
\hline Mato Grosso & $R \$ 76,1$ & $\mathrm{R} \$ 88,0$ & $\mathrm{R} \$ 69,6$ & $\mathrm{R} \$ 49,2$ & $\mathrm{R} \$ 71,8$ & $R \$ 126,2$ & $R \$ 120,3$ & $\mathrm{R} \$ 2,0$ & $R \$ 25,0$ & $R \$ 7,0$ & $\mathrm{R} \$ 0,0$ & $\mathrm{R} \$ 8,3$ & $\mathrm{R} \$ 0,0$ & $\mathrm{R} \$ 0,0$ & $\mathrm{R} \$ 0,0$ & $R \$ 0,0$ & $\mathrm{R} \$ 0,1$ \\
\hline $\begin{array}{l}\text { Mato Grosso } \\
\text { do Sul }\end{array}$ & $\mathrm{R} \$ 73,3$ & $\mathrm{R} \$ 160,9$ & $\mathrm{R} \$ 113,7$ & $\mathrm{R} \$ 104,1$ & $\mathrm{R} \$ 56,0$ & $\mathrm{R} \$ 96,9$ & $\mathrm{R} \$ 141,1$ & $\mathrm{R} \$ 1,3$ & $\mathrm{R} \$ 51,0$ & $R \$ 66,0$ & $\mathrm{R} \$ 11,7$ & $\mathrm{R} \$ 10,8$ & $\mathrm{R} \$ 0,0$ & $\mathrm{R} \$ 0,0$ & $\mathrm{R} \$ 0,0$ & $\mathrm{R} \$ 0,0$ & $\mathrm{R} \$ 0,1$ \\
\hline Minas Gerais & $\mathrm{R} \$ 279,4$ & $\mathrm{R} \$ 366,1$ & $\mathrm{R} \$ 340,0$ & $\mathrm{R} \$ 124,4$ & $\mathrm{R} \$ 261,3$ & $\mathrm{R} \$ 410,3$ & $\mathrm{R} \$ 340,9$ & $\mathrm{R} \$ 115,1$ & $\mathrm{R} \$ 194,5$ & $R \$ 98,9$ & $\mathrm{R} \$ 173,6$ & $\mathrm{R} \$ 115,9$ & $\mathrm{R} \$ 0,3$ & $\mathrm{R} \$ 0,0$ & $\mathrm{R} \$ 0,0$ & $\mathrm{R} \$ 0,0$ & $\mathrm{R} \$ 1,5$ \\
\hline Para & $\mathrm{R} \$ 36,8$ & $R \$ 439,6$ & $\mathrm{R} \$ 195,6$ & $\mathrm{R} \$ 25,2$ & $\mathrm{R} \$ 69,2$ & $\mathrm{R} \$ 111,9$ & $\mathrm{R} \$ 125,5$ & $\mathrm{R} \$ 0,1$ & $\mathrm{R} \$ 48,1$ & $\mathrm{R} \$ 127,6$ & $\mathrm{R} \$ 30,3$ & $\mathrm{R} \$ 2,0$ & $\mathrm{R} \$ 0,0$ & $\mathrm{R} \$ 0,0$ & $\mathrm{R} \$ 0,0$ & $\mathrm{R} \$ 0,0$ & $\mathrm{R} \$ 1,2$ \\
\hline Paraíba & $\mathrm{R} \$ 266,6$ & $R \$ 423,6$ & $R \$ 200,8$ & $R \$ 50,7$ & $R \$ 108,5$ & $R \$ 230,0$ & $R \$ 214,8$ & $\mathrm{R} \$ 42,4$ & $\mathrm{R} \$ 80,4$ & $R \$ 90,2$ & $\mathrm{R} \$ 40,6$ & $\mathrm{R} \$ 20,3$ & $R \$ 2,3$ & $\mathrm{R} \$ 0,0$ & $\mathrm{R} \$ 0,0$ & $\mathrm{R} \$ 0,0$ & $\mathrm{R} \$ 0,3$ \\
\hline Paraná & $\mathrm{R} \$ 59,2$ & $\mathrm{R} \$ 111,7$ & $\mathrm{R} \$ 86,2$ & $\mathrm{R} \$ 30,6$ & $\mathrm{R} \$ 71,5$ & $\mathrm{R} \$ 146,6$ & $\mathrm{R} \$ 104,8$ & $\mathrm{R} \$ 0,4$ & $\mathrm{R} \$ 45,5$ & $R \$ 43,0$ & $\mathrm{R} \$ 8,4$ & $\mathrm{R} \$ 7,7$ & $\mathrm{R} \$ 2,8$ & $\mathrm{R} \$ 0,0$ & $\mathrm{R} \$ 0,0$ & $\mathrm{R} \$ 0,0$ & $\mathrm{R} \$ 1,6$ \\
\hline Pernambuco & $\mathrm{R} \$ 431,6$ & $\mathrm{R} \$ 761,6$ & $\mathrm{R} \$ 396,4$ & $\mathrm{R} \$ 201,7$ & $\mathrm{R} \$ 295,7$ & $\mathrm{R} \$ 199,4$ & $\mathrm{R} \$ 362,2$ & $\mathrm{R} \$ 53,1$ & $\mathrm{R} \$ 223,0$ & $\mathrm{R} \$ 110,6$ & $\mathrm{R} \$ 91,1$ & $\mathrm{R} \$ 28,5$ & $\mathrm{R} \$ 12,2$ & $\mathrm{R} \$ 104,2$ & $\mathrm{R} \$ 3,3$ & $\mathrm{R} \$ 0,0$ & $\mathrm{R} \$ 0,6$ \\
\hline Piauí & $\mathrm{R} \$ 171,4$ & $R \$ 322,1$ & $\mathrm{R} \$ 282,5$ & $\mathrm{R} \$ 80,6$ & $\mathrm{R} \$ 170,4$ & $\mathrm{R} \$ 192,2$ & $R \$ 143,1$ & $\mathrm{R} \$ 51,8$ & $\mathrm{R} \$ 27,6$ & $\mathrm{R} \$ 18,2$ & $\mathrm{R} \$ 2,1$ & $\mathrm{R} \$ 5,7$ & $\mathrm{R} \$ 2,2$ & $\mathrm{R} \$ 0,0$ & $\mathrm{R} \$ 0,0$ & $\mathrm{R} \$ 0,0$ & $\mathrm{R} \$ 1,3$ \\
\hline $\begin{array}{l}\text { Rio de } \\
\text { Janeiro }\end{array}$ & $\mathrm{R} \$ 246,7$ & $R \$ 461,7$ & $\mathrm{R} \$ 130,4$ & $\mathrm{R} \$ 69,8$ & $R \$ 121,6$ & $\mathrm{R} \$ 250,9$ & $R \$ 244,1$ & $\mathrm{R} \$ 85,8$ & $\mathrm{R} \$ 259,8$ & $R \$ 537,9$ & $R \$ 610,6$ & $\mathrm{R} \$ 103,4$ & $\mathrm{R} \$ 0,0$ & $\mathrm{R} \$ 0,0$ & $\mathrm{R} \$ 0,0$ & $\mathrm{R} \$ 0,0$ & $\mathrm{R} \$ 0,0$ \\
\hline $\begin{array}{l}\text { Rio Grande } \\
\text { do Norte }\end{array}$ & $R \$ 205,0$ & $\mathrm{R} \$ 273,5$ & $\mathrm{R} \$ 125,8$ & $\mathrm{R} \$ 55,4$ & $\mathrm{R} \$ 116,6$ & $\mathrm{R} \$ 112,1$ & $\mathrm{R} \$ 88,4$ & $\mathrm{R} \$ 3,2$ & $\mathrm{R} \$ 60,7$ & $\mathrm{R} \$ 17,6$ & $\mathrm{R} \$ 45,9$ & $\mathrm{R} \$ 0,6$ & $\mathrm{R} \$ 4,7$ & $\mathrm{R} \$ 0,0$ & $\mathrm{R} \$ 0,0$ & $\mathrm{R} \$ 0,0$ & $\mathrm{R} \$ 0,5$ \\
\hline $\begin{array}{l}\text { Rio Grande } \\
\text { do Sul }\end{array}$ & $\mathrm{R} \$ 232,1$ & $\mathrm{R} \$ 142,7$ & $R \$ 117,3$ & $\mathrm{R} \$ 188,8$ & $R \$ 282,0$ & $R \$ 308,0$ & $R \$ 313,3$ & $R \$ 206,6$ & $\mathrm{R} \$ 297,1$ & $R \$ 619,4$ & $\mathrm{R} \$ 674,1$ & $\mathrm{R} \$ 499,5$ & $R \$ 446,8$ & $\mathrm{R} \$ 105,4$ & $\mathrm{R} \$ 111,2$ & $R \$ 245,3$ & $R \$ 239,4$ \\
\hline Rondônia & $\mathrm{R} \$ 80,0$ & $\mathrm{R} \$ 106,9$ & $\mathrm{R} \$ 70,3$ & $\mathrm{R} \$ 18,5$ & $\mathrm{R} \$ 24,1$ & $\mathrm{R} \$ 64,2$ & $\mathrm{R} \$ 41,0$ & $\mathrm{R} \$ 8,5$ & $\mathrm{R} \$ 19,4$ & $\mathrm{R} \$ 37,1$ & $\mathrm{R} \$ 14,6$ & $\mathrm{R} \$ 0,0$ & $\mathrm{R} \$ 0,0$ & $\mathrm{R} \$ 0,0$ & $\mathrm{R} \$ 0,0$ & $\mathrm{R} \$ 0,0$ & $\mathrm{R} \$ 0,0$ \\
\hline Roraima & $\mathrm{R} \$ 78,7$ & $\mathrm{R} \$ 80,8$ & $\mathrm{R} \$ 33,8$ & $\mathrm{R} \$ 9,7$ & $\mathrm{R} \$ 16,5$ & $\mathrm{R} \$ 12,0$ & $R \$ 54,3$ & $\mathrm{R} \$ 0,7$ & $\mathrm{R} \$ 6,9$ & $\mathrm{R} \$ 30,1$ & $\mathrm{R} \$ 11,6$ & $\mathrm{R} \$ 0,0$ & $\mathrm{R} \$ 0,0$ & $\mathrm{R} \$ 0,0$ & $\mathrm{R} \$ 0,0$ & $\mathrm{R} \$ 0,0$ & $\mathrm{R} \$ 0,0$ \\
\hline $\begin{array}{l}\text { Santa } \\
\text { Catarina }\end{array}$ & $\mathrm{R} \$ 149,3$ & $R \$ 205,9$ & $\mathrm{R} \$ 180,6$ & $\mathrm{R} \$ 41,5$ & $\mathrm{R} \$ 80,0$ & $\mathrm{R} \$ 100,8$ & $\mathrm{R} \$ 93,6$ & $\mathrm{R} \$ 2,6$ & $\mathrm{R} \$ 25,5$ & $\mathrm{R} \$ 4,1$ & $\mathrm{R} \$ 40,3$ & $\mathrm{R} \$ 17,1$ & $\mathrm{R} \$ 0,1$ & $\mathrm{R} \$ 0,0$ & $\mathrm{R} \$ 0,0$ & $\mathrm{R} \$ 0,0$ & $\mathrm{R} \$ 2,0$ \\
\hline São Paulo & $\mathrm{R} \$ 859,1$ & $\mathrm{R} \$ 712,8$ & $\mathrm{R} \$ 671,2$ & $\mathrm{R} \$ 133,7$ & $R \$ 429,1$ & $\mathrm{R} \$ 574,5$ & $\mathrm{R} \$ 632,0$ & $\mathrm{R} \$ 480,5$ & $\mathrm{R} \$ 225,3$ & $R \$ 461,5$ & $\mathrm{R} \$ 386,8$ & $\mathrm{R} \$ 66,6$ & $\mathrm{R} \$ 0,0$ & $\mathrm{R} \$ 0,0$ & $\mathrm{R} \$ 0,0$ & $\mathrm{R} \$ 0,0$ & $\mathrm{R} \$ 6,0$ \\
\hline Sergipe & $\mathrm{R} \$ 141,4$ & $\mathrm{R} \$ 213,4$ & $\mathrm{R} \$ 143,4$ & $\mathrm{R} \$ 40,2$ & $\mathrm{R} \$ 83,1$ & $\mathrm{R} \$ 87,8$ & $\mathrm{R} \$ 68,5$ & $\mathrm{R} \$ 0,2$ & $\mathrm{R} \$ 34,6$ & $\mathrm{R} \$ 65,2$ & $\mathrm{R} \$ 37,0$ & $\mathrm{R} \$ 4,2$ & $\mathrm{R} \$ 0,0$ & $\mathrm{R} \$ 0,0$ & $\mathrm{R} \$ 0,0$ & $\mathrm{R} \$ 0,0$ & $\mathrm{R} \$ 0,1$ \\
\hline Tocantins & $\mathrm{R} \$ 55,9$ & $\mathrm{R} \$ 453,4$ & $R \$ 166,9$ & $\mathrm{R} \$ 37,1$ & $\mathrm{R} \$ 27,9$ & $\mathrm{R} \$ 70,1$ & $\mathrm{R} \$ 75,8$ & $\mathrm{R} \$ 1,6$ & $\mathrm{R} \$ 25,1$ & $\mathrm{R} \$ 21,9$ & $\mathrm{R} \$ 0,3$ & $\mathrm{R} \$ 0,0$ & $R \$ 0,0$ & $\mathrm{R} \$ 0,0$ & $\mathrm{R} \$ 0,0$ & $\mathrm{R} \$ 0,0$ & $\mathrm{R} \$ 0,4$ \\
\hline $\begin{array}{l}\text { Não } \\
\text { especificado }\end{array}$ & $\mathrm{R} \$ 5.808,1$ & $\mathrm{R} \$ 4.175,2$ & $\mathrm{R} \$ 24.009,2$ & $\mathrm{R} \$ 9.429,1$ & $\mathrm{R} \$ 3.781,9$ & $\mathrm{R} \$ 4.313,6$ & $\mathrm{R} \$ 5.079,6$ & $\mathrm{R} \$ 11.739,4$ & $\mathrm{R} \$ 1.807,4$ & $\mathrm{R} \$ 5.293,9$ & $\mathrm{R} \$ 5.347,5$ & $\mathrm{R} \$ 2.699,9$ & $\mathrm{R} \$ 6.669,2$ & $\mathrm{R} \$ 11.364,1$ & $\mathrm{R} \$ 28.081,3$ & $\mathrm{R} \$ 19.439,6$ & $R \$ 9.369,9$ \\
\hline
\end{tabular}

Quadro Anexo 5: Territorialização do financiamento fiscal do desenvolvimento urbano: Valores liquidados por Estado. Valores em milhões. Ano referência de valores: 2016. Fonte: Sistema Integrado de Planejamento e Orçamento, Ministério do Planejamento, Desenvolvimento e Gestão do Governo Federal. Elaboração nossa. 


\begin{tabular}{|c|c|c|c|c|c|c|c|c|c|c|c|c|c|c|c|}
\hline & 2003 & 2004 & 2005 & 2006 & 2007 & 2008 & 2009 & 2010 & 2011 & 2012 & 2013 & 2014 & 2015 & 2016 & TOTAL \\
\hline \multicolumn{16}{|c|}{ INFRAESTRUTURA E SERVIÇOS URBANOS } \\
\hline $\begin{array}{l}\text { 2.4.7.2.03.05 - CONVÊNIO } \\
\text { SIURB X ESTADO }\end{array}$ & RS- & RS & RS- & RS- & $\mathrm{R} \$-$ & $\mathrm{R} \$-$ & $\mathrm{RS}-$ & $\mathrm{RS}-$ & $\mathrm{RS}-$ & R\$- & R\$- & $\mathrm{RS}-$ & RS- & R\$- & $\mathrm{R} \$-$ \\
\hline $\begin{array}{l}\text { 2.4.7.2.05.02 - CONVÊNIO } \\
\text { JACU - PÊSSEGO }\end{array}$ & RS- & $\mathrm{R} \$-$ & RS- & $\mathrm{R} \$-$ & RS- & RS- & RS- & R\$- & $R \$-$ & R\$- & $R \$-$ & RS- & R\$- & RS- & RS- \\
\hline $\begin{array}{l}\text { 2.4.7.2.99.02 - CONVÊNIO } \\
\text { SIURB - ESTADO }\end{array}$ & RS- & RS- & RS- & $\mathrm{R} \$ 5,840$ & RS- & $\mathrm{R} \$ 4,246$ & RS- & RS- & RS- & RS- & RȘ- & RS- & RS- & RS- & $R \$ 10,087$ \\
\hline $\begin{array}{l}\text { 2.4.7.2.99.63 - CONVÊNIO } \\
\text { SIURB X ESTADO }\end{array}$ & RSS- & RS- & RS- & RS- & RS\$- & RS- & RS- & RS- & RS- & RS- & RS- & RS- & RS- & $\mathrm{R} \$ 14,300$ & $\mathrm{R} \$ 14,300$ \\
\hline \multicolumn{16}{|l|}{ SANEAMENTO BASICO } \\
\hline $\begin{array}{l}\text { 1.7.2.2.299.04 - FEHIDRO - } \\
\text { FUNDO ESTADUAL DE RECURSOS } \\
\text { HÍDRICOS }\end{array}$ & RS- & RS- & RS- & $\mathrm{R} \$ 0,021$ & $\mathrm{R} \$ 0,233$ & $R \$ 0,035$ & $\mathrm{R} \$ 0,216$ & RS- & RS- & RS- & RS- & RS- & RS- & RS- & $\mathrm{R} \$ 0,505$ \\
\hline 1.7.2.2.99.06 - FEMA & RŞ- & $\mathrm{R} \$-$ & $R \$-$ & RS- & RS- & R\$- & RS- & $R \$-$ & $R \$-$ & $\mathrm{R} \$-$ & RS- & RS- & $\mathrm{R} \$-$ & $R \$-$ & $R \$-$ \\
\hline $\begin{array}{l}\text { 1.7.6.2.99.16 - CONVÊNIO } \\
\text { FEHIDRO }\end{array}$ & 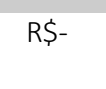 & RS- & $R \$$ & RS- & RŞ- & $R \$-$ & RS- & RS- & 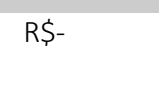 & RS- & RŞ- & $R \$-$ & RS- & 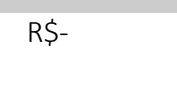 & $R \$-$ \\
\hline $\begin{array}{l}\text { 2.4.7.2.03.02 - CONVÊNII } \\
\text { PMSP X SAAESP - FUNDO } \\
\text { MUNIIIALL DE SANEAMENTO } \\
\text { AMBIENTAL E INF / 2.4.7.7.2.03.52- } \\
\text { CONVÊNIO PMSS X SABESP - } \\
\text { FUNDO MUNCIPAL DE } \\
\text { SANEAMENTO AMBIENTAL E INF }\end{array}$ & $R \$-$ & RS- & RS - & $R \$-$ & RS- & RS- & RS- & RS\$- & $\mathrm{R} \$ 436,587$ & $\mathrm{R} \$ 456,544$ & $\mathrm{R} \$ 452,532$ & $\mathrm{R} \$ 406,420$ & $\mathrm{R} \$ 308,108$ & $R \$ 377,759$ & $\mathrm{R} \$ 2.437,952$ \\
\hline $\begin{array}{l}\text { 2.4.7.2.03.03 - CONVÊNIO } \\
\text { PMSP/SIURB X SABESP }\end{array}$ & RS- & $\mathrm{RS}-$ & $R \$-$ & 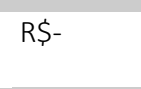 & RȘ- & RȘ- & RŞ- & $\mathrm{RS}-$ & $R S-$ & $\mathrm{R} \$-$ & RS\$- & RS\$- & $\mathrm{R} \$-$ & RS- & RS- \\
\hline $\begin{array}{l}\text { 2.4.7.2.03.04 - CONVÊNIO } \\
\text { PMSP X SABESP }\end{array}$ & RS- & RŞ- & $R \$-$ & RS- & $R \$-$ & RS - & RŞ- & RS- & $R \$-$ & $\mathrm{R} \$ 0,604$ & $R \$-$ & $R \$-$ & $R \$-$ & $R \$-$ & $\mathrm{R} \$ 0,604$ \\
\hline \multicolumn{16}{|l|}{ HABITAÇÃO } \\
\hline $\begin{array}{l}\text { 1.7.6.2.99.57 - CONVÊNIO } \\
\text { COHAB X ESTADO }\end{array}$ & RS- & RȘ- & RS- & RȘ- & RS- & RS- & RS- & RS- & RS- & RS- & $R S$ & RS- & RS- & $\mathrm{R} \$ 0,140$ & $\mathrm{R} \$ 0,140$ \\
\hline $\begin{array}{l}\text { 2.4.7.2.03.01 - CONVÊNIO } \\
\text { SEHAB X ESTADO }\end{array}$ & $R \$-$ & $R \$-$ & $R \$-$ & $R \$-$ & $R \$-$ & $R \$-$ & $R \$-$ & $R \$-$ & $R \$-$ & $\mathrm{R} \$ 14,813$ & $\mathrm{R} \$ 4,216$ & $\mathrm{R} \$ 0,537$ & $\mathrm{R} \$ 1,152$ & $R \$-$ & $\mathrm{R} \$ 20,718$ \\
\hline $\begin{array}{l}\text { 2.4.7.2.03.51 - CONVÊNIO } \\
\text { SEHAB X ESTADO }\end{array}$ & RS- & RS- & $R \$-$ & RS- & $R \$-$ & RS- & RS- & $R \$-$ & $R \$-$ & RS- & $R \$-$ & RS- & RS\$- & $R \$-$ & RS- \\
\hline $\begin{array}{l}\text { 2.4.7.2.99.05 - CONVÊNIO } \\
\text { CDHU X SEHAB }\end{array}$ & RŞ- & $R S-$ & RȘ- & $R \$ 40,499$ & $\mathrm{R} \$ 196,350$ & $\mathrm{R} \$ 137,581$ & $R \$ 84,250$ & RS- & $\mathrm{R} \$ 0,000$ & $\mathrm{R} \$ \mathbf{4} 4,115$ & $\mathrm{R} \$ 11,196$ & $\mathrm{R} \$ 10,725$ & $\mathrm{R} \$ 27,853$ & $R \$-$ & $R \$ 552,568$ \\
\hline $\begin{array}{l}\text { 2.4.7.2.99.07 - CT / CEF / } \\
\text { SEHAB / MIN CIDADES PAC } \\
\text { ESTADUAL / MANANCIAIS LOTES I } \\
\text { A }\end{array}$ & $R \$-$ & $R \$-$ & $R \$-$ & $R \$-$ & $R \$-$ & $R \$-$ & $R \$-$ & $\mathrm{R} \$ 185,833$ & $R \$ 87,671$ & $R \$ 30,851$ & $R \$-$ & $R \$-$ & $R \$-$ & $R \$-$ & $\mathrm{R} \$ 304,355$ \\
\hline $\begin{array}{l}\text { 2.4.7.2.99.10 - CONVÊNIO } \\
\text { SEHAB X ESTADO }\end{array}$ & RŞ- & RSS- & $R S-$ & $R S-$ & RS- & $\mathrm{R} \$ 7,306$ & $\mathrm{R} \$ 194,077$ & $\mathrm{R} \$ 3,471$ & RS- & $\mathrm{R} \$ 14,049$ & $R \$ 14,755$ & $\mathrm{R} \$ 1,079$ & RȘ- & $R \$-$ & $R \$ 234,738$ \\
\hline $\begin{array}{l}\text { 2.4.7.2.99.15 - CONVÊNIO } \\
\text { COHAB-SP/FMH E CDHU }\end{array}$ & RS- & RȘ- & $R \$-$ & $R \$-$ & $R \$-$ & RS- & $R \$-$ & $R \$-$ & $R \$-$ & $\mathrm{R} \$ 12,245$ & $\mathrm{R} \$ 1,637$ & $\mathrm{R} \$ 0,413$ & RS- & $R \$-$ & $\mathrm{R} \$ 14,294$ \\
\hline $\begin{array}{l}\text { 2.4.7.2.99.16 - CONVÊNIO } \\
\text { FMH X ESTADO }\end{array}$ & RS - & RS- & 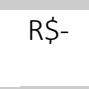 & RS- & RS- & RS\$- & RS- & RS- & RS\$- & $R \$-$ & $R S-$ & RS\$- & RS- & RS- & RS- \\
\hline $\begin{array}{l}\text { 2.4.7.2.99.17 - CONVÊNIO } \\
\text { COHAB-SP X CPTM }\end{array}$ & $R \$-$ & $R \$-$ & $R \$-$ & $R \$-$ & $R \$-$ & $R \$-$ & $R \$-$ & $R \$-$ & RS- & RS- & 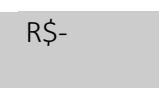 & $R \$-$ & RS- & $R \$-$ & $R \$-$ \\
\hline $\begin{array}{l}\text { 2.4.7.2.99.18 - CONVÊNIO } \\
\text { COHAB-SP X DERSA }\end{array}$ & RS- & RS- & RS- & RS- & RSS- & RS- & RS- & RS- & RS- & RS- & RŞ- & $R S-$ & RS- & RS- & RS- \\
\hline $\begin{array}{l}\text { 2.4.7.2.99.53 - CONVÊNIO } \\
\text { CDHU X SEHAB }\end{array}$ & RŞ- & RS- & RȘ- & RS- & RS- & RS- & RŞ- & RS- & RS- & RS- & RS- & RS- & RSS- & $\mathrm{R} \$ 11,632$ & $\mathrm{R} \$ 11,632$ \\
\hline $\begin{array}{l}\text { 2.4.7.2.99.55 - CONVÊNIO } \\
\text { SEHAB X ESTADO }\end{array}$ & RŞ- & RS- & RȘ- & RS- & RȘ- & RS- & RS- & RS- & RS- & RS- & RS- & RS- & RS\$- & $R \$ 55,234$ & $R \$ 55,234$ \\
\hline TOTAL GERAL/ANO & RS- & R\$- & R\$- & $\mathrm{R} \$ 46,360$ & $\mathrm{R} \$ 196,583$ & $\mathrm{R} \$ 149,168$ & $\mathrm{R} \$ 278,543$ & $\mathrm{R} \$ 189,304$ & $\mathrm{R} \$ 524,258$ & $R \$ 573,222$ & $\mathrm{R} \$ 484,336$ & $\mathrm{R} \$ 419,174$ & $\mathrm{R} \$ 337,113$ & $R \$ 459,066$ & $R \$ 3.657,128$ \\
\hline
\end{tabular}

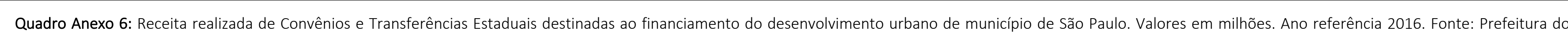
Município de São Paulo. Elaboração nossa. 


\begin{tabular}{|c|c|c|c|c|c|c|c|c|c|c|c|c|c|c|c|}
\hline & 2003 & 2004 & 2005 & 2006 & 2007 & 2008 & 2009 & 2010 & 2011 & 2012 & 2013 & 2014 & 2015 & 2016 & TOTAL \\
\hline \multicolumn{16}{|c|}{ INFRAESTRUTURA E SERVIÇOS URBANOS } \\
\hline $\begin{array}{l}\text { 1.7.2.1.09.06 - MINISTÉRIO } \\
\text { DAS CIDADES /CEF X SMSP }\end{array}$ & RS- & RS- & $\mathrm{R} \$ 0,189$ & RS- & RS- & RS- & RS- & RS- & RS- & RS- & RS- & RS- & RS- & RS- & $R \$ 0,189$ \\
\hline $\begin{array}{l}\text { 1.7.2.1.99.06 - MINISTÉRIO } \\
\text { DAS CIDADES/CEF X SMSP }\end{array}$ & RS- & RS\$- & RS- & RS- & RSS- & RSS- & RS- & RSS- & RSS- & RS- & RS- & RS- & RS- & RS- & RS- \\
\hline $\begin{array}{l}\text { 1.7.6.1.99.32 - CONVÊNIO } \\
\text { SMPED X UNIÂO }\end{array}$ & RS- & RS- & RS- & RS- & RS- & RS- & RS- & RS- & $\mathrm{RS}-$ & RS- & RS- & RS- & $\mathrm{R} \$ 0,216$ & RS- & $\mathrm{R} \$ 0,216$ \\
\hline $\begin{array}{l}\text { 1.7.6.1.99.77 - CONVÊNIO } \\
\text { SMDU X UNIÃOO }\end{array}$ & RSS- & RSS- & RS- & RS- & RS- & RS- & RS- & RS- & RS- & RS- & RS- & RS- & $\mathrm{R} \$ 0,107$ & RS- & $\mathrm{R} \$ 0,107$ \\
\hline $\begin{array}{l}\text { 2.4.2.1.99.02 - PROGRAMA } \\
\text { DE REESTRUTURAÇAOO URBANA - } \\
\text { SISTEMA VIÁRIO JACU- } \\
\text { PÊSSEGO/MINIST }\end{array}$ & RS- & $R \$ 10,050$ & $R \$ 85,050$ & RS- & RS- & R\$- & RS- & RS- & RS- & RS- & RS- & RS- & R\$- & RS- & $R \$ 95,100$ \\
\hline $\begin{array}{l}\text { 2.4.2.2.1.99.03- TERMINAL } \\
\text { FERNÄO DIAS/MINST. DOS } \\
\text { TRANSPORTES }\end{array}$ & RS- & $R S-$ & $R S-$ & RS- & RS- & RSS- & RSS- & RSS- & $R S-$ & RS- & RSS- & RS- & RS- & RS- & RS- \\
\hline 2.4.2.1.99.05 - RADIAL LESTE & RS- & $\mathrm{R} \$ 22,184$ & RȘ- & RS- & RS- & RS- & RS- & RS- & RS- & RS- & RS- & RS- & RS- & RS- & $\mathrm{R} \$ 22,184$ \\
\hline $\begin{array}{l}\text { 2.4.2.1.99.13 - PROGRAMA } \\
\text { DE RESTRUTURAÇÃO URBANA - } \\
\text { SISTEMA VIÁRIO - MINISTERRIO DAS } \\
\text { CI }\end{array}$ & RS- & $R \$ 35,520$ & $R \$-$ & $R \$ 5,405$ & $\mathrm{R} \$-$ & $R \$-$ & $\mathrm{R} \$-$ & $R \$-$ & RS- & $\mathrm{R} \$-$ & RS- & RS- & RS- & RS- & $\mathrm{R} \$ 40,924$ \\
\hline $\begin{array}{l}\text { 2.4.2.1.99.18 - PMSP X } \\
\text { MCIDADES/CEF - CONTRATO DE } \\
\text { REPASSE No } 01746\end{array}$ & RS- & RS- & RS- & RS- & RS- & $\mathrm{R} \$ 0,034$ & RS- & RS- & RS- & RS- & RS- & RS- & RS- & RS- & $\mathrm{R} \$ 0,034$ \\
\hline $\begin{array}{l}\text { 2.4.2.1.99.21 - PMSP/SIURB X } \\
\text { MIN. CIDADES/CEF/PAC - BACIA } \\
\text { DO CÓRREGO CORDEIRO }\end{array}$ & $\mathrm{R} \$-$ & RS- & RS- & $\mathrm{R} \$-$ & $\mathrm{RS}-$ & RS- & RS- & RS- & RS- & RS- & RS- & RS- & R\$- & R\$- & R\$- \\
\hline $\begin{array}{l}\text { 2.4.2.1.99.22 - PMSP/SIURB X } \\
\text { MIN. CIDADES/CEF/PAC- } \\
\text { CÓRREGO PIRAJUSSARA }\end{array}$ & RS- & RS- & RS- & RS- & RS- & RS- & RS- & RS- & RS- & RS- & RS- & RS\$- & RS- & RS- & RS\$- \\
\hline $\begin{array}{l}\text { 2.4.2.1.99.23 - SES - CT CEF/ } \\
\text { MIN. CIDADES }\end{array}$ & $\mathrm{RS}-$ & RS- & $\mathrm{RS}-$ & $\mathrm{RS}-$ & $\mathrm{RS}-$ & RS- & RS- & RS- & $R \$ 2,361$ & RS- & RS- & RS- & RS- & $\mathrm{R} \$-$ & $\mathrm{R} \$ 2,361$ \\
\hline $\begin{array}{l}\text { 2.4.2.1.99.25 - SIURB X } \\
\text { MINISTERIO DAS CIDADES }\end{array}$ & RS- & RS- & RS- & RS- & RS- & RS- & RS- & RS- & RS- & RS- & $\mathrm{R} \$ 91,561$ & $\mathrm{R} \$ 276,177$ & $\mathrm{R} \$ 181,960$ & RS- & $R \$ 549,698$ \\
\hline $\begin{array}{l}\text { 2.4.2.1.99.26 - SMT/FMDT X } \\
\text { UNIÂO }\end{array}$ & RS- & RS- & RS- & RS- & RS- & $R S-$ & RS- & RS- & RS- & RS- & RS- & RS- & RS- & RS- & RS- \\
\hline $\begin{array}{l}\text { 2.4.2.1.99.27 - SMT/SPTRANS } \\
\text { X UNIÂOO }\end{array}$ & RS- & RS- & RS- & RS- & RS- & RS- & RS- & RS- & RS- & RS- & RS- & RS- & $R \$-$ & RS- & RS\$- \\
\hline $\begin{array}{l}\text { 2.4.7.1.03.01 - CONVÊNIO } \\
\text { SIURB X UNIÄO }\end{array}$ & RS- & RS- & RS- & RS- & $\mathrm{R} \$-$ & $R \$-$ & RS- & $R \$-$ & $R \$-$ & RS- & RS- & RS- & $R \$-$ & RS- & RS- \\
\hline $\begin{array}{l}\text { 2.4.7.1.03.51 - CONVÊNIO } \\
\text { SIURB X UNIÄO }\end{array}$ & RS- & RS- & RS- & RS- & RS- & RS- & RS- & RS- & RS- & RS- & RS- & RS- & RS- & $\mathrm{R} \$ 46,557$ & $\mathrm{R} \$ 46,557$ \\
\hline $\begin{array}{l}\text { 2.4.7.1.05.02 - CONVÊNIO } \\
\text { JACU - PÊSSEGO }\end{array}$ & $R \$-$ & $R S-$ & RS- & RS- & RS- & RS- & RS- & RS- & RS- & RS- & RS- & RS- & RS- & RS- & RȘ- \\
\hline $\begin{array}{l}\text { 2.4.7.1.05.03 - TERMINAL DE } \\
\text { CARGAS FERNÃO DIAS/MT- } \\
\text { DNIT/SP-MG }\end{array}$ & RS- & RS- & RS- & $\mathrm{R} \$ 17,087$ & RS- & RS- & RS- & RS- & RS- & RS- & RS- & RS- & RS- & RS- & $\mathrm{R} \$ 17,087$ \\
\hline $\begin{array}{l}\text { 2.4.7.1.99.20 - CONVÊNIO } \\
\text { SMT - FMDT X UNIÃO }\end{array}$ & $\mathrm{RS}-$ & RS- & RS- & $\mathrm{R} \$-$ & $\mathrm{R} \$-$ & RS- & $R \$-$ & $R \$-$ & $R S-$ & RS- & RS- & RS- & $R S-$ & RS- & RS- \\
\hline $\begin{array}{l}\text { 2.4.7.1.99.25 - CONVÊNIO } \\
\text { SIURB X UNIÂOO }\end{array}$ & RS- & RSS- & RS- & RS- & RS- & RS- & RS- & RS- & RS- & RS- & RS- & RS- & RS- & RS- & RS- \\
\hline $\begin{array}{l}\text { 2.4.7.1.99.64 - CONVÊNIO } \\
\text { SMSP - UNIÂOO }\end{array}$ & RS- & RS- & RS- & RS- & RS- & RS- & RS- & RS- & RS- & $R \$-$ & RS- & RS- & RS- & RS- & RS- \\
\hline \multicolumn{16}{|l|}{ SANEAMENTO BÁSICO } \\
\hline $\begin{array}{l}\text { 1.7.6.1.99.31 - CONVÊNIO } \\
\text { AMLURB X UNIÃOO }\end{array}$ & RS- & RS\$- & RS\$- & RS- & RSS- & RS- & RS- & RS- & RS- & RS- & RS- & $\mathrm{R} \$ 0,595$ & RSS- & RS- & $\mathrm{R} \$ 0,595$ \\
\hline $\begin{array}{l}\text { 1.7.6.1.99.72 - CONVÊNIO } \\
\text { AMLURB X UNIÂOO }\end{array}$ & $\mathrm{RS}-$ & RS- & RS- & RS- & RS- & RS- & RS- & RS- & RS- & RS- & RS- & RS- & RS- & $\mathrm{R} \$ 0,014$ & $\mathrm{R} \$ 0,014$ \\
\hline $\begin{array}{l}\text { 2.4.7.1.99.33 - CONVÊNIO } \\
\text { AMLURB X BNDES }\end{array}$ & RS- & $\mathrm{RS}-$ & RS- & RS- & RS- & RS- & RS- & RS- & RS- & RS- & RS- & RS- & RS- & RS- & RS- \\
\hline
\end{tabular}




\begin{tabular}{|c|c|c|c|c|c|c|c|c|c|c|c|c|c|c|c|}
\hline $\begin{array}{l}\text { 2.4.7.1.99.35 - CONVÊNIO } \\
\text { AMLURB X MINISTERRIO DAS } \\
\text { CIDADES }\end{array}$ & $R \$-$ & RŞ- & RS\$- & RS- & RS\$- & RŞ- & RS- & RS- & RS- & RS- & RS- & RS- & RŞ- & RS- & R\$- \\
\hline $\begin{array}{l}\text { 2.4.7.1.99.39 - CONVÊNIO } \\
\text { AMLURB X UNIẪO }\end{array}$ & $R \$-$ & RŞ- & RŞ- & $R \$-$ & $R \$-$ & RŞ- & RS- & RŞ- & RŞ- & $R \$-$ & RS- & $R \$ 2,945$ & $R \$-$ & $R \$-$ & $\mathrm{R} \$ 2,945$ \\
\hline $\begin{array}{l}\text { 2.4.7.1.99.76 - CONVÊNIO } \\
\text { AMLURB X BNDES }\end{array}$ & RS- & RS- & RS- & RS- & RS- & RS- & RS- & RS- & RS- & $R \$-$ & RȘ- & RȘ- & $R \$-$ & $R \$-$ & RS- \\
\hline $\begin{array}{l}\text { 2.4.7.7.1.99.78 - CONVÊNIO } \\
\text { AMLURB X MINISTÉRIO DAS } \\
\text { CIDADES }\end{array}$ & RS- & RȘ- & RS- & RS\$- & RS- & RS- & RS- & RȘ- & RȘ- & RS\$- & RȘ- & RȘ- & RS - & RS- & RS\$- \\
\hline $\begin{array}{l}\text { 2.4.7.1.99.82 - CONVÊNIO } \\
\text { AMLURB X UNIÂAO }\end{array}$ & RS- & RS- & RŞ- & RS- & RS- & RS- & RS- & RS- & RS- & RS\$- & RȘ- & RŞ- & RS- & RS- & RS- \\
\hline 1.7.2.1.09.06 - DNAEE & RS- & $\mathrm{R} \$ 0,085$ & RSS- & RS- & RS- & RS- & RS- & RȘ- & RȘ- & RS- & RȘ- & RŞ- & $R \$-$ & $R \$-$ & $\mathrm{R} \$ 0,085$ \\
\hline $\begin{array}{l}\text { 1.7.2.1.09.10 - FUNDO } \\
\text { ESPECILL MEIO AMBIENTAL E } \\
\text { DESENVOLVIMENTO } \\
\text { SUSTENTÁVEL }\end{array}$ & RS- & RS- & RS- & RS- & RS- & RS- & RS- & RS - & RS - & RS- & RS - & RŞ- & RS- & R\$- & R\$- \\
\hline $\begin{array}{l}\text { 1.7.2.1.99.04 - FEMA - } \\
\text { FUNDO ESECAAL DO MEIO } \\
\text { AMBIENTE E DESENVVOLVIMENTO } \\
\text { SUSTENTÁVEL }\end{array}$ & RS- & RS- & RS- & RS- & RS- & RSS- & RS- & R\$- & RȘ- & RSS- & $R S$ & RŞ- & RS- & $R \$-$ & RS- \\
\hline $\begin{array}{l}\text { 1.7.6.1.99.18 - CONVÊNIO } \\
\text { SVMA - UNIÂOO }\end{array}$ & RS- & RS & RS- & RS- & RS- & RS- & RS- & $R \$-$ & $R \$-$ & R\$- & RS- & RSS- & RSS- & RSS- & $R \$-$ \\
\hline $\begin{array}{l}\text { 2.4.2.1.1.99.06 - PROGRAMA } \\
\text { DE DRENAGEM/MINISTÉRIO DA } \\
\text { INTEGRAÇÃO NACIONAL }\end{array}$ & RS- & RS- & 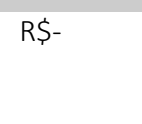 & RS- & RS- & $R S-$ & RS- & RȘ- & RŞ- & 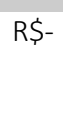 & $R \grave{-}$ & $R \grave{-}$ & RS- & R\$- & RS- \\
\hline $\begin{array}{l}\text { 2.4.2.1.99.17 - PMSP/ PAT- } \\
\text { PROSANEAR - MCIDADES/CEF- } \\
\text { HABI }\end{array}$ & RS- & RS- & RS- & $\mathrm{R} \$ 1,310$ & $\mathrm{R} \$ 4,891$ & $R \$ 3,250$ & RS- & RȘ- & RȘ- & RS & RȘ- & RS- & RS- & RS- & $R \$ 9,451$ \\
\hline $\begin{array}{l}\text { 2.4.7.1.04.01 - PMSP-SVMA- } \\
\text { PARQUE NATRRAL MUNCIPAL DA } \\
\text { CRATERA DE COLONIA/CONVÊNIO } \\
\text { FURN }\end{array}$ & $R \$-$ & RS- & RS- & RS- & RS- & RS- & $R S-$ & RȘ- & RȘ- & RS\$- & $R S-$ & $R \hat{-}$ & RS- & R\$- & RS- \\
\hline $\begin{array}{l}\text { 2.4.7.1.99.14 - CONVÊNIO } \\
\text { SVMA - UNIÃO }\end{array}$ & $R \$-$ & RS- & $R \$-$ & RS- & RS- & $R \$-$ & $R \$-$ & $R \$-$ & $R \$-$ & $R \$-$ & $R \$-$ & $R \$-$ & $R \$-$ & $R \$-$ & $R \$-$ \\
\hline HABITAÇÃO & & & & & & & & & & & & & & & \\
\hline $\begin{array}{l}\text { 1.7.2.1.99.03 - PROGRAMA } \\
\text { MORAR MELHOR - CONTRATO No } \\
\text { 0157896-38/2003 - MINISTÉRIO } \\
\text { DAS C }\end{array}$ & RS- & RS- & RS- & RS- & RS- & RS- & RS- & RŞ- & RŞ- & RS- & RS- & RS- & RS- & RS- & RS- \\
\hline $\begin{array}{l}\text { 1.7.6.1.99.33 - CONVÊNIO } \\
\text { COHAB X UNIÃO }\end{array}$ & RSS- & RS- & RȘ- & RS- & RS- & RS- & RS- & RS'- & RS- & RS- & RȘ- & $R \$ 0,034$ & $\mathrm{R} \$ 0,140$ & RS- & $\mathrm{R} \$ 0,175$ \\
\hline $\begin{array}{l}\text { 1.7.6.1.99.74 - CONVÊNIO } \\
\text { COHAB X UNIÃO }\end{array}$ & RS- & RS- & RS- & RS- & RS- & RS- & RS- & RS- & 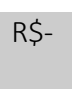 & $R \$-$ & $R \$-$ & RŞ- & $R \$-$ & $\mathrm{R} \$ 0,136$ & $\mathrm{R} \$ 0,136$ \\
\hline $\begin{array}{l}\text { 2.4.2.1.99.08 - PROGRAMA } \\
\text { MORAR MELOR - CONTRATO No } \\
\text { 157896-38/2003 - MINISTÉRIO } \\
\text { DAS CI }\end{array}$ & $R \$-$ & $\mathrm{R} \$ 8,040$ & $R \$-$ & RS- & RS- & RS- & RS- & RŞ- & RŞ- & $R \$-$ & RS\$- & RŞ- & RS- & RS- & $\mathrm{R} \$ 8,040$ \\
\hline $\begin{array}{l}\text { 2.4.2.1.99.12 - PROGRAMA } \\
\text { MORAR MELHOR }\end{array}$ & RS- & $R \$ 37,995$ & $\mathrm{R} \$ 1,512$ & RS- & RS- & RS- & RS- & RS- & RS- & RS- & RS- & RS- & $R \$-$ & $R \$-$ & $\mathrm{R} \$ 39,507$ \\
\hline $\begin{array}{l}\text { 2.4.2.1.99.14 - PROGRAMA } \\
\text { MORAR NO CENTRO }\end{array}$ & RS- & RS- & RS- & RS- & RS- & RS - & RS- & RS- & RS- & RS- & $R S-$ & RSS- & RS- & RS- & RS- \\
\hline $\begin{array}{l}\text { 2.4.2.1.99.15 - PROGRAMA } \\
\text { BAIRRO LEGAL }\end{array}$ & RS- & RS- & $\mathrm{R} \$ 47,250$ & RS- & RS- & RS- & RS- & RŞ- & RS- & RS- & RŞ- & RŞ- & RS- & RS- & $\mathrm{R} \$ 47,250$ \\
\hline $\begin{array}{l}\text { 2.4.2.1.99.16 - PROGRAMA } \\
\text { MUTIRÃO/SEHAB }\end{array}$ & RS- & RS- & RS- & RS- & RS- & RS- & RS- & RŞ- & RŞ- & RS'- & 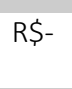 & RS- & RS- & RS- & $R S-$ \\
\hline $\begin{array}{l}\text { 2.4.2.1.99.18 - PMSP X } \\
\text { MEIDADES/CEF - CONTRATO DE } \\
\text { REPASSE N } 0174641-03 / 2005 \text { - } \\
\text { HABI }\end{array}$ & RS- & RS- & RS- & $\mathrm{R} \$ 0,179$ & $\mathrm{R} \$ 0,686$ & RS- & RS- & RS- & RS- & RS- & RS- & RS- & RS- & RS- & $\mathrm{R} \$ 0,866$ \\
\hline $\begin{array}{l}\text { 2.4.2.1.99.19 - SEHAB - CT } \\
\text { CEF / MIN. CIDADES } \\
\text { (N.S.APARECIDA / VERGUEIRINHO) }\end{array}$ & $R \$-$ & RS- & $R \$-$ & RS- & $\mathrm{R} \$ 17,332$ & RS- & RS- & RS- & RS- & 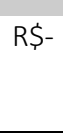 & RŞ- & RŞ- & $R \$-$ & $\mathrm{R} \$-$ & $R \$ 17,332$ \\
\hline
\end{tabular}




\begin{tabular}{|c|c|c|c|c|c|c|c|c|c|c|c|c|c|c|c|}
\hline $\begin{array}{l}\text { 2.4.2.1.99.20 - SEHAB-CT } \\
\text { CEF/MIN.CID/PAC } \\
\text { (HELIOPOLIS/PQ.FERNANDA/CID A }\end{array}$ & RS- & RS- & RS- & R\$- & R\$- & R\$153,900 & $\mathrm{R} \$ 260,230$ & $\mathrm{R} \$ 137,084$ & $R \$ 66,970$ & $R \$ 64,950$ & $R \$ 21,462$ & $\mathrm{R} \$ 8,079$ & $\mathrm{R} \$ 3,485$ & RS- & R\$716,159 \\
\hline $\begin{array}{l}\text { 2.4.2.1.99.28 - SEHAB X } \\
\text { MINISTÉRIO DAS CIDADES/ PAC 2- } \\
\text { PARAÍSOPOLIS }\end{array}$ & $R \$-$ & R\$- & RS- & $R \$-$ & $R \$-$ & RS- & $R \$-$ & RS- & $R \$-$ & $\mathrm{R} \$ 6,025$ & RS- & $R \$ 3,508$ & $R \$ 9,127$ & $R \$-$ & $R \$ 18,660$ \\
\hline $\begin{array}{l}\text { 2.4.2.1.99.29 - SEHABX X } \\
\text { MINISTÉRIO DAS CIDADES/PAC 2- } \\
\text { SAAO FRANCISCO }\end{array}$ & R\$- & R\$- & RS- & R\$- & RS- & RS- & RS- & RS- & $R \$-$ & RS- & $R \$ 9,989$ & RS- & $\mathrm{R} \$ 14,613$ & RS- & $R \$ 24,602$ \\
\hline $\begin{array}{l}\text { 2.4.2.1.99.30 - SEHAB X MIN. } \\
\text { CID./PAC 2 - OBRAS REG E INT ASS } \\
\text { PREC }\end{array}$ & RS- & R\$- & RS- & R\$- & R\$- & RS- & $R \$-$ & $R \$-$ & $R S-$ & $R \$-$ & $\mathrm{R} \$ 4,390$ & $\mathrm{R} \$ 12,207$ & RS- & $R \$-$ & $\mathrm{R} \$ 16,597$ \\
\hline $\begin{array}{l}\text { 2.4.7.1.99.23 - CONVÊNIO } \\
\text { COHAB-SP X UNIÃO }\end{array}$ & R\$- & R\$- & RS- & R\$- & RS- & RS- & RS- & $R \$-$ & $R \$-$ & RS- & RS- & RS- & $R \$-$ & $R \$-$ & R\$- \\
\hline $\begin{array}{l}\text { 2.4.7.1.99.24 - CONVÊNIO } \\
\text { FMH X UNIÂAO }\end{array}$ & $R \$-$ & $\mathrm{R} \$-$ & $R \$-$ & RS- & RS- & $R \$-$ & $R \$-$ & $R \$-$ & $R \$-$ & RS- & RS- & RS- & RS- & RS- & RS- \\
\hline $\begin{array}{l}\text { 2.4.7.1.99.34 - CONVÊNIO } \\
\text { SEHAB X UNIÂOO }\end{array}$ & R\$- & R\$- & RS- & R\$- & RS- & $R \$-$ & $R \$-$ & $R \$-$ & $R \$-$ & RS- & RS- & RS- & $\mathrm{R} \$ 0,484$ & RS- & $\mathrm{R} \$ 0,484$ \\
\hline $\begin{array}{l}\text { 2.4.7.1.199.66 - CONVÊNIO } \\
\text { COHAB-SP X UNIÃO }\end{array}$ & RS- & R\$- & R\$- & R\$- & R\$- & RS- & RS- & RS- & RS- & RS- & RS- & RS- & $R \$-$ & RS- & RS- \\
\hline $\begin{array}{l}\text { 2.4.7.1.99.67 - CONVÊNIO } \\
\text { FMH X UNIÂAO }\end{array}$ & RS- & RS- & R\$- & R\$- & RS- & $R \$-$ & $R \$-$ & $R \$-$ & $R \$-$ & RS- & RS- & RS- & RS- & RS- & RS- \\
\hline $\begin{array}{l}\text { 2.4.7.1.99.77 - CONVÊNIO } \\
\text { SEHAB X XNIÃOA }\end{array}$ & RS- & R\$- & RS- & RS- & $\mathrm{RS}-$ & $\mathrm{RS}-$ & $\mathrm{RS}-$ & RS- & $\mathrm{RS}-$ & $\mathrm{RS}-$ & $\mathrm{RS}-$ & $\mathrm{RS}-$ & $R \$-$ & $\mathrm{R} \$ 7,428$ & $\mathrm{R} \$ 7,428$ \\
\hline TOTAL GERAL/ANO & RS\$- & $\mathrm{R} \$ 113,874$ & $\mathrm{R} \$ 134,001$ & $R \$ 23,980$ & $R \$ 22,909$ & $\mathrm{R} \$ 157,183$ & $\mathrm{R} \$ 260,230$ & $\mathrm{R} \$ 137,084$ & $R \$ 69,331$ & R\$70,976 & $\mathrm{R} \$ 127,402$ & $\mathrm{R} \$ 303,545$ & $\mathrm{R} \$ 210,132$ & $R \$ 54,136$ & $\mathrm{R} \$ 1.684,784$ \\
\hline
\end{tabular}

Quadro Anexo 7: Receita realizada de Convênios e Transferências Federais destinadas ao financiamento do desenvolvimento urbano de município de São Paulo. Valores em milhões. Ano referência 2016. Fonte: Prefeitura do Município de São Paulo. Elaboração nossa. 